\title{
AN ANALYSIS OF THE INTER-DEPENDENCY OF THE PROMINENT MOTIFS WITHIN THE BOOK OF QOHELET
}

\author{
A Dissertation \\ Presented to the Faculty of \\ Southeastern Baptist Theological Seminary \\ Wake Forest, North Carolina
}

In Partial Fulfillment

of the requirements for the Degree

Doctor of Philosophy

by

Richard Alan Fuhr Jr.

October, 2008 
This Dissertation was prepared and presented to the Faculty as a part of the requirements for the Doctor of Philosophy degree at Southeastern Baptist Theological Seminary, Wake Forest, North Carolina. All rights and privileges normally reserved by the author as copyright holder are waived for the Seminary. The Seminary Library may catalog, display, and use this Dissertation in all normal ways such materials are used, for reference and for other purposes, including electronic and other means of preservation and circulation, including on-line computer access and other means by which library materials are or in the future may be available to researchers and library users. 


\section{SOUTHEASTERN}

BAPTIST THEOLOGICAL

SEMINARY

\section{Ph.D. Dissertation Approval}

Student Name: Richard Alan Fuhr Jr

Student ID\#

Dissertation Title:

\section{AN ANALYSIS OF THE INTER-DEPENDENCY OF THE PROMINENT MOTIFS WITHIN THE BOOK OF QOHELET}

This Dissertation has been approved.

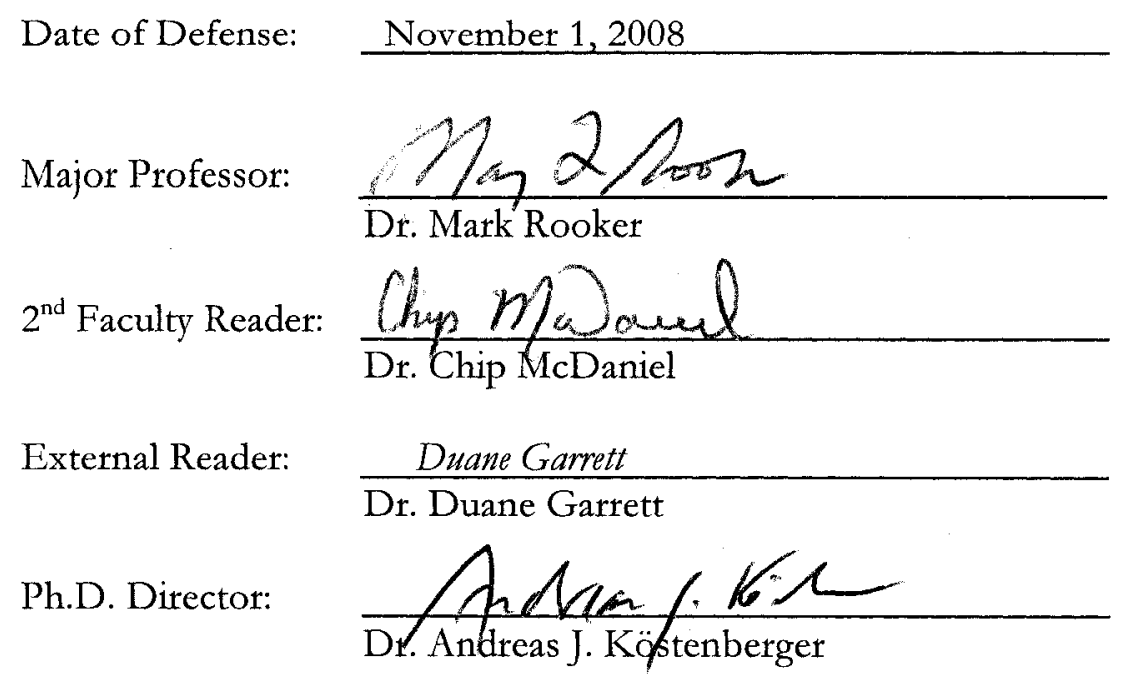

iii 


\section{CONTENTS}

ABSTRACT

viii

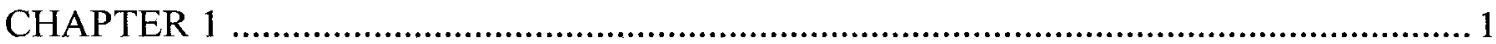

PRELIMINARY CONSIDERATIONS AND INTRODUCTION ..................................... 1

The Need for Balance in Approaching the Book of Qohelet ...........................................

The Question of Contradiction and Tension in Qohelet .............................................. 13

The Question of Genre, Authorship, and Date within the Book of Qohelet ........................ 18

A Survey of Prominent Motifs Observable within Qohelet and an Inter-dependent

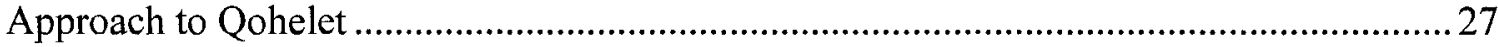

A Balanced Paradigm for Living: The Inter-dependency of the Prominent Motifs in

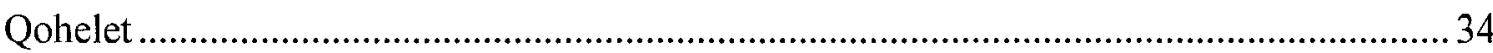

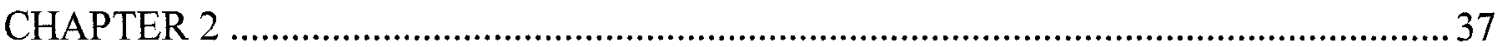

THE DILEMMA OF הבל AND THE QUEST FOR יתרון IN THE BOOK OF QOHELET

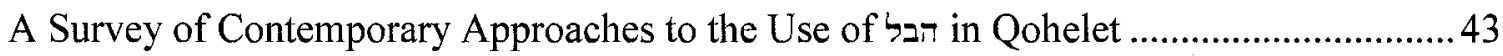

הבל Understood Exclusively as "Fleeting," "Transitory," or "Brevity"............................. 44

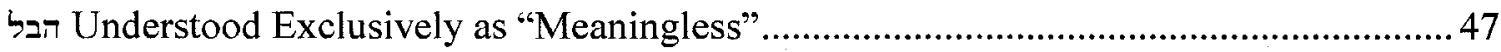

Understood as Denoting Futility Based on the Recognition of Transience .................... 48

iv 
הבל Understood as "Enigmatic"

הבל Understood as "Incomprehensible".

הבל Understood as "Absurdity" 53

Understood as "Unsatisfactory," "Frustrating," or "Foulness" 54

Other Miscellaneous Definitions for 56

Understood in a Unique Sense not Translatable into any Single English Term 57

The Flexible Nature of Metaphor as Depicted in דבל 59

דבל as Symbol in Qohelet 60

The "Transience Family" 65

The "Vanity Family" 67

The "Irony Family" .71

The "Frustration Family" 74

The Dilemma of הבל. 76

CHAPTER 3 82

LIVING "UNDER THE SUN": THE QUESTION OF THEOLOGICAL CONTEXT AND PERSPECTIVE IN THE BOOK OF QOHELET 82

The Scope of Qohelet's Observations - Life "Under the Sun" 84

The Distinction between Qohelet's Use of the Phrases "Under the Sun" and "Under the Heavens" 87

The Perspective of Qohelet's Inquiry-The Context of Life Observed "Under the Sun".... 90 $\mathrm{V}$ 
CHAPTER 4

LOOKING THROUGH THE "LENS OF WISDOM": THE ROLE OF WISDOM AND

GENRE IN THE BOOK OF QOHELET

What Kind of Wisdom is This?

Looking through the Lens of Wisdom 106

Wisdom as Motif in Qohelet.

Concluding Thoughts.

CHAPTER 5

HOW INSCRUTABLE ARE THE WAYS OF GOD! THE RELATIONSHIP BETWEEN

GOD AND MAN IN THE BOOK OF QOHELET .

Sovereignty and Determinacy in Qohelet's Theology of God....

The Imposition of Limitation in Qohelet's Theology of Man

Time, Circumstance, and Probabilistic Wisdom

CHAPTER 6

THE INESCAPABLE DESTINY OF ALL MEN: THE INEVITABILITY OF DEATH

MOTIF IN THE BOOK OF QOHELET

Principles on Death and the Afterlife in Qohelet.....

CHAPTER 7

WHAT WILL THE WISE MAN DO? THE ENJOYMENT OF LIFE CONCLUSIONS IN

THE BOOK OF QOHELET 175

vi 
The Divine Gift of Enjoyment

The Wisdom of Joy 201

CHAPTER 8

WHAT WILL THE WISE MAN DO? THE FEAR OF GOD CONCLUSIONS IN THE

BOOK OF QOHELET

Remembering One's Creator - The Centrality of the Fear of God in Qohelet .206

The Fear of God and the "Whole of Man".

The Fear of God and the Appointed Time of Judgment

The Enjoyment of Life and the Fear of God

CHAPTER 9

IN CONCLUSION: THE INTER-DEPENDENCY OF THE PROMINENT MOTIFS IN THE BOOK OF QOHELET 231

The Inter-dependency of הבל to Related Motifs. 232

יתרון, הבל, and the Pursuit of Wisdom .232

הבל and its Relationship to the Inevitability of Death .233

הבל and Its Relationship to the Determinacy of God and the Limitation of Man .234

The Inter-dependency of Wisdom to Related Motifs .236

Realism and the Capacity to Affect Change: Probabilistic Wisdom and Its Relationship to

Determinacy and Limitation 236

vii 
A New Paradigm for Living: How Wisdom Relates to the Enjoyment of Life and the Fear of God 238

The Inter-dependency of the Inevitability of Death to Related Motifs. 239

The Ultimate Display of Divine Determinism: The Inevitability of Death, Divine Jurisdiction, and the Inability of Man to Know His Future 239

The Inevitability of Death as Motivation to Seize the Day. 240

The Inevitability of Death as Motivation to Fear God 241

The Inter-dependency of the Enjoyment of Life and the Fear of God to Related Motifs.. 242 Hבל Haw the Wise Should Live: The Balanced, Two-fold Wisdom Response to Living in World. 246

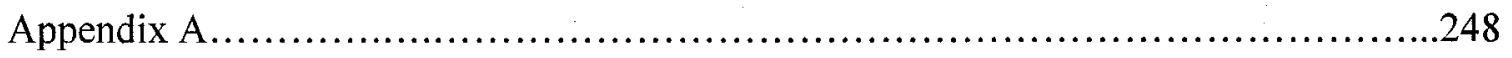

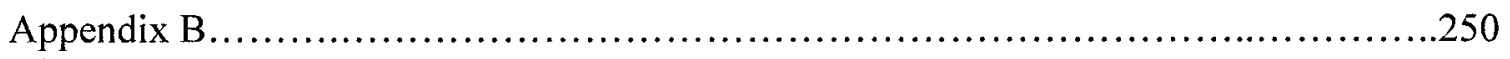

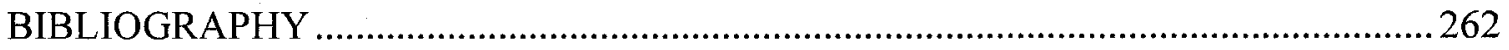

viii 


\begin{abstract}
This dissertation analyses and evaluates the seven most prominent motifs in the book of Qohelet with a view towards demonstrating the inter-dependency between these motifs. As each motif is evaluated in light of its relationship to other prominent motifs, a balanced approach to Qohelet is reached.
\end{abstract}

Chapter one presents an introduction to the background issues vital to Qohelet studies, along with a survey of current approaches and the presuppositions from which my own analysis of Qohelet will be taken. Chapter 2 begins the evaluation of motifs, focusing on the problem, or "dilemma" of and Qohelet's quest to find a "solution," or תרון, which may in some way provide an answer to the "dilemma." Chapter 3 serves as an excursus of sorts, dealing with the theological context and perspective from which Qohelet writes, namely, the "under the sun" perspective.

Chapters 4 through 6 continue the analysis of the other prominent motifs observable within Qohelet, including the role of wisdom, divine determinacy and mortal limitations, and finally, the inevitability of death. The analysis conducted in each of these chapters explores the nature of each motif along with primary issues relevant to a proper exegetical understanding of each.

Chapters 7 and 8 continue to explore the details regarding an understanding of prominent motifs, although the focus now shifts to the concluding motifs of the "enjoyment of life" and the "fear of God." The enjoyment of life and the fear of God are presented as wisdom based imperatives that bring Qohelet's quest to a conclusion.

ix 
Finally, chapter 9 concludes the analysis of the inter-dependency of the motifs, and proposes an approach to the book that incorporates a positive, wisdom based paradigm for living in a fallen world. 


\section{CHAPTER 1}

\section{PRELIMINARY CONSIDERATIONS AND INTRODUCTION}

Within the Hebrew canon, perhaps no book has eluded a consensus as to issues of origin, theology, interpretation, and genre more than Qohelet. ${ }^{1}$ In the field of Old Testament scholarship, Qohelet has been examined through the various methods of biblical criticism as scholars strive to make sense of its apparent in-text contradictions and theological message. ${ }^{2}$ Within popular circles, Qohelet is largely ignored by both clergy and laity as they struggle to find its central message and an appropriate approach that brings theological continuity to the text. ${ }^{3}$

For many years, published works on Qohelet have lagged far behind the quantity and quality of works appropriated to other portions of the Old Testament. ${ }^{4}$ In recent decades, however, a great surge of interest has occurred in the field of Qohelet studies, so

\footnotetext{
${ }^{1}$ While this opening statement is rather sweeping in its claim, and is difficult to validate in a statistical manner, the following dissertation will support the above claim as scholars are surveyed chapter by chapter on a variety of introductory and exegetical issues.

${ }^{2}$ For an excellent survey of the various methods of biblical criticism, see John Barton, Reading the Old Testament: Method in Biblical Study, revised ed. (Louisville: Westminster John Knox Press, 1996). While not the final word on critical methodology, Barton's text is especially helpful in regards to how these methods have been applied to Qohelet, in that he uses Qohelet as the biblical text for case examples throughout his work.

${ }^{3}$ While taking an academic rather than popular approach to the issue at hand, it is largely this matter of "message" or "approach" to Qohelet that constitutes the primary concerns and thesis examined throughout this dissertation.

${ }^{4}$ The English title Ecclesiastes (derived from the LXX) will be substituted with the Hebrew title of the book, Qohelet. However, when quoting or referencing others who refer to the book as "Ecclesiastes," the English title will then be used. Also, when quoting or referencing writers who use variations of the spelling "Qohelet," the spelling will default to that of the author being quoted or referenced.
} 
much so that the interested reader will find no lack of material available on the subject. What has become evident throughout this recent surge of published works, however, is that there is still little scholarly consensus regarding how one should approach the book of Qohelet. While a comprehensive survey is not necessary in laying the foundation and providing rationale for the following dissertation, it is prudent to begin our introduction by briefly summarizing the manner in which Qohelet has been approached both historically as well as in contemporary scholarship.

Among ancient Jewish and early Christian commentaries on Qohelet, there exists general continuity in following a pre-critical, if not allegorical, approach to Qohelet. ${ }^{5}$ Whether or not the book was approached allegorically, or better, regardless of the extent of allegorization applied to the book, ${ }^{6}$ the general approach in pre-critical readings of Qohelet was to distinguish between words pertaining to the "realm under the sun" and to those pertaining to Torah, and thus to read the epilogue as "the key to the book."7

\footnotetext{
${ }^{5}$ While doubtless a generalization, and for the purposes of this study, a rather vague hermeneutical categorization, the idea of a "pre-critical" approach to Qohelet falls quite in line with what one would expect among commentators of any canonical book from antiquity through the period of the Reformation. For detailed inquiry into the hermeneutical shift that occurred in biblical studies during the eighteenth and nineteenth centuries, especially in distinguishing between a "pre-critical" and "critical" approach, see Hans W. Frei, The Eclipse of Biblical Narrative: Study in Eighteenth and Nineteenth Century Hermeneutics (New Haven and London: Yale University Press, 1974).

${ }^{6}$ Allegorical and excessively theological readings of Qohelet were common in Jewish and in Christian circles, but were especially prolific within the writings of the church fathers. For instance, note the soteriological distinction drawn between life "under the sun" and life "in the sun of righteousness" in the comments of Didymus the Blind, "If a person says about himself that he is a Christian and enlightened by the true light, by the 'sun of righteousness,' and still concentrates his actions on earthly things and strives after them (and we all are for the most part like these people) this person is 'under the sun." Likewise, Origen equates the imperative to "let your garments always be white" (Qoh 9:8) to the washing of regeneration in baptism, "Wisdom also has commanded this elsewhere, saying, "Let your garments be clean at all times.' For your garments were washed once when you came to the grace of baptism; you were purified in body; you were cleansed from all filth of flesh and spirit." On Didymus the Blind, see Dieter Hagedorn, Rudolf Kassel, Ludwig Koenen, and Reinhold Merkelbach, eds. Papyrologische Texte und Abhandlungen (Bonn: Habelt, 1968), 225. On Origen, see Ronald E. Heine, trans. Fathers of the Church: A New Translation (Washington, D.C.: Catholic University of America Press, 1947), 365.
}

${ }^{7}$ Craig G. Bartholomew, "Ecclesiastes," DTIB (Grand Rapids: Baker Academic, 2005), 182. 
Furthermore, pre-critical approaches to Qohelet, among Jewish as well as Christian

thinkers, convey a universal assumption of Solomonic authorship. The assumption of a Solomonic context, both historically and canonically, played a major role in impacting the exegetical conclusions among early commentators. Jewish interpretation of the rabbinic period (A.D. 70 to A.D. 640) tended to center on the primacy of the Torah, the dethronement and subsequent repentance of the author Solomon, and a view towards a belief in the world to come as central hermeneutical presuppositions. ${ }^{8}$ Such is reflected in the expansionistic tendencies of the Targum's rendering of 1:12, wherein "Ecclesiastes became the witness to his [Solomon's] return to orthodoxy at the end of his life, and his apostasy then becomes a foil to teach others of the dangers of wandering from the true God [and thus, from Torah]."9

While early Jewish commentators viewed Qohelet through the "lens" of Torah, early Christian writers combined an assumption of Solomonic authorship with a view towards the enhancement of the spiritual life of the church to arrive at a thoroughly "ecclesiastical" approach to Qohelet. ${ }^{10}$ Church fathers such as Origen and Jerome

\footnotetext{
${ }^{8}$ Roland Murphy, Ecclesiastes, Word Biblical Commentary vol. 23a (Nashville: Thomas Nelson, 1992), liii-lv.

${ }^{9}$ Tremper Longman III, The Book of Ecclesiastes, New International Commentary on the Old Testament (Grand Rapids: Eerdmans, 1998), 3. The Targum of Qoh 1:12 is translated thus: "When King Solomon was sitting upon the throne of his kingdom, his heart became very proud of his riches, and he violated the word of God, by gathering many horses, chariots and riders, and amassing much gold and silver. And he married from foreign nations, whereupon the anger of the Lord was kindled against him, and he sent to him Ashmodai, king of the demons, who drove him from his kingdom's throne, and took away the ring from his hand, in order that he should roam and wander about in the world to reprove it. And he roamed about in the outlying towns and the cities of the land of Israel, weeping and lamenting, and saying, 'I am Qohelet, whose name was formerly called Solomon, who was king over Israel in Jerusalem'." For a full translation and commentary, see E. Levine, The Aramaic Version of Qohelet (New York: SepherHermon, 1978), 28.
}

\footnotetext{
${ }^{10}$ Beryl Smalley comments regarding the role of Solomonic authorship upon medieval exegesis: "The patristic tradition on the 'books of Solomon' derived from Origen; it was transmitted by St. Jerome, and reproduced in the Gloss. Solomon wrote his three books, Proverbs, Ecclesiastes, and the Canticle, in
} 
reinterpreted Qohelet from an orthodox point of view, commonly digressing to allegorization and at times even directly refuting the words of Qohelet in order to maintain orthodoxy at every opportunity. Typical of such an approach are the comments of Jerome (summarized by Murphy) in reference to Qoh 1:12: "If God made everything good, how is it vanity? Everything is good per se, but nothing compared to God." ${ }^{11}$ Other commentators went so far as to view Qohelet as a type of Christ (Didymus, Origen, Gregory of Nyssa); others saw in the title "Ecclesiastes" a picture of the church (Jerome, Gregory of Nyssa), and most patristic commentators viewed all references to "vanity" as a depiction of the world (thus encouraging an ascetic lifestyle). ${ }^{12}$

The period of the Reformation was marked by a substantial shift away from monastic theology that interpreted Qohelet to teach "contempt for the world," moving rather towards a more humanistic, positive approach. Despite the exegetical advancement away from allegorization, Reformation exegesis of Qohelet nevertheless was rife with pre-suppositional tendencies, often revealing the theological concerns of the Reformation as seen in commentaries produced by Martin Luther (1532), Johannes Brenz (1528), and Philip Melanchthon (1550). ${ }^{13}$ Theologically, the Reformers viewed the book of Qohelet as a discourse against the doctrine of free-will (Luther), as a treatise in favor of the

order to instruct mankind in the three states of the spiritual life. Proverbs taught men how to live virtuously in the world and was meant for beginners. Ecclesiastes taught them how to despise the things of the world as futile and as fleeting and was meant for proficientes [those who are progressing]. The Canticle told initiates of the love of God." See Beryl Smalley, Medieval Exegesis of Wisdom Literature: Essays, ed. R.E. Murphy (Atlanta: Scholars Press, 1986), 40.

${ }^{11}$ Murphy, Ecclesiastes, li.

${ }^{12}$ J. Robert Wright, ed. Proverbs, Ecclesiastes, Song of Solomon, Ancient Christian Commentary on Scripture (Downers Grove: Intervarsity, 2005), 190-91. For a more comprehensive view of patristic, expositional commentary on the text of Qohelet, see Wright, Proverbs, Ecclesiastes, Song of Solomon, 191285.

\footnotetext{
${ }^{13}$ Murphy, Ecclesiastes, lii.
} 
doctrine of divine providence (Melanchthon), and as an illustration of Pauline justification (Brenz). ${ }^{14}$ While certainly beneficial as a contribution to the history of Qohelet studies, the Reformers nevertheless allowed their theological concerns to be overly influential in their approach to the book.

Beginning as early as 1644 , the pre-critical approach of the Reformers was replaced by the historical-critical exegesis that has played an increasingly prominent role in Qohelet studies up into the modern period. ${ }^{15}$ The historical-critical approach to Qohelet is characterized by the critical reconstruction of historical conditions behind the events, figures, and development of the text. ${ }^{16}$ More specifically, the source critical approach to Qohelet as pioneered by C. Siegfried sought to deconstruct the text into separate written sources; Siegfried himself noted no fewer than nine different sources in the history of the development of Qohelet. ${ }^{17}$ Such an approach has continued into the $20^{\text {th }}$ century, and often underlies the assumptions of contemporary scholars who recognize the

\footnotetext{
${ }^{14}$ Thomas Kruger, Qoheleth, Hermeneia (Minneapolis: Augsburg Fortress, 2004), 34. See also Martin Luther, "Notes on Ecclesiastes," Luther's Works (J. Pelikan, ed., St. Louis: Concordia, 1972), 15:3187; Philip Melanchthon, "Enarratio Brevis ... Ecclesiastes," Corpus Reformatorium (C. G. Bretschnieder, ed., Halle: Schwetschke, 1847), 14: 89-159 and Johannes Brenz, Der Prediger Salomo: FaksimileNeudruck der ersten Ausgabe Hagenau 1528 (Stuttgart: Frommann, 1970).

${ }^{15}$ The first written work to question Solomonic authorship comes via Hugo Grotius in his Annotations in Vetus Testamentum, part 1 (Paris, 1644). He states in part, "I do not believe that [the book of Qoheleth] is from Solomon. Rather, it is written under the name of that king, as if he were led to repentance. As a proof of this I take many words which are not found elsewhere except in Daniel, Ezra, and in the Aramaic translations." The above quote is referenced as found in F. Bianchi, "The Language of Qoheleth: A Bibliographical Survey," ZAW 105 (1993): 210-11.

${ }^{16}$ Kruger affirms the value of a critical approach in relieving exegesis of interest in "contemporary convictions" and understanding the text as a "historical document" in conjunction with the study of other biblical and extra-biblical texts. See Kruger, Qoheleth, 34.

${ }^{17}$ C. Siegfried, Prediger und Hoheslied (Gottingen: Vandenhoeck und Ruprecht, 1898).
} 
work of redactors throughout the text of Qohelet. ${ }^{18}$ Distinct from, yet also in conjunction with a source critical approach, form critical scholars approach Qohelet as a skeptical reaction to mainline wisdom, recreating a "crisis in wisdom" that provides the historical basis behind the creation of the text of Qohelet. ${ }^{19}$ Meanwhile, the canonical critical approach has also contributed to modern scholarship, reinforcing the role of the epilogue as the canonical key to harmonizing Qohelet with the whole of Scripture. ${ }^{20}$ In the history of Qohelet scholarship, the significance of critical approaches to the book of Qohelet can hardly be underestimated. ${ }^{21}$

As though viewing contemporary scholarship through the prognosticator's lens, the words of Bishop Robert Lowth apply as well to today as they did to his own century when assessing the current state of Qohelet scholarship: "Scarcely any two commentators have agreed concerning the plan of the work, and accurate division of it into parts or sections. ${ }^{22} \mathrm{~A}$ comprehensive survey of contemporary approaches to Qohelet reveals an

${ }^{18}$ Representative $20^{\text {th }}$ century source critical works in the English language include G.A. Barton, A Critical and Exegetical Commentary on the Book of Ecclesiastes, ICC (Edinburgh: T \& T Clark, 1912) and A.H. McNeile, An Introduction to Ecclesiastes (Cambridge: Cambridge University, 1904).

${ }^{19}$ While form critical analysis of Qohelet can be traced back to Hermann Gunkel, the influence of such thinking has permeated modern scholarship in Qohelet studies. For an overview of the "crisis in wisdom" approach and its roots in form critical analysis, see Kathleen A. Farmer in The Hebrew Bible Today: An Introduction to Critical Issues, ed. Steven L. McKenzie and M. Patrick Graham (Louisville: Westminster John Knox, 1998), 129-50.

${ }^{20}$ While canonical critical hermeneutics is rightly associated with Bernard Childs, its influence and appropriation in Qohelet studies is clearly discernable in a variety of evangelical commentaries, including those by Michael Eaton and Tremper Longman III. See Michael Eaton, Ecclesiates, Tyndale Old Testament Commentaries (Downers Grove: Intervarsity, 1983) and Longman, Ecclesiastes. For the seminal work in canonical criticism, see Bernard Childs, Introduction to the Old Testament as Scripture (Minneapolis: Fortress, 1979).

${ }^{21}$ For an excellent introduction to biblical criticism, made all the more valuable by its use of Qohelet as the primary text for illustration, see John Barton, Reading the Old Testament.

${ }^{22}$ Bishop Robert Lowth, Lectures on the Sacred Poetry of the Hebrews, Lecture 24 (Boston: Buckingham, 1815): 342. 
exceptionally wide range of perspectives and opinions regarding the "key" motifs and exegetical pre-suppositions necessary for an accurate and honest reading of the book. While a truly comprehensive survey is impossible for the purposes of this work, it will be of help to briefly survey some of the more prominent commentators along with their approaches to Qohelet.

Although a survey of contemporary approaches to Qohelet could easily be organized under a variety of equally valid means, perhaps the best way to divide the field is to distinguish between those approaches which are generally pessimistic, those which are generally optimistic, and those that warrant special consideration due to their nontraditional treatment of Qohelet. As with any survey of this sort, it is difficult and unnecessary to draw hard and fast lines; indeed, many of the "approaches" surveyed below demonstrate characteristics that may best be described as "balanced" or "neutral," and thus it is best to recognize these approaches as "distinguishable" only as weighed by degree. Nevertheless, Qohelet has traditionally been recognized as conveying either a positive message or a negative message, and in this tradition many contemporary scholars have followed suit.

Read positively, the book of Qohelet compliments rather than contradicts Proverbs and Job, and thus constitutes a "heightening" and enhancement of Hebrew wisdom literature. ${ }^{23}$ Contemporary commentators reading the book as generally optimistic include Ian Provan, Daniel C. Fredericks, Kathleen Farmer, R. N. Whybray, Elsa Tamez, Duane Garrett, Robert Gordis, Choon-Leong Seow, Eunny P. Lee, and

\footnotetext{
${ }^{23}$ Bartholomew, "Ecclesiastes," 184.
} 
Walter Kaiser. ${ }^{24}$ Recent popular level works promoting a generally optimistic approach to Qohelet include those by Jeffrey Meyers and Ray Waddle. ${ }^{25}$ Commentators who take a generally negative approach in assessing the thrust of Qohelet's message include James Crenshaw, Michael Eaton, Derek Kidner, Tremper Longman III, Thomas Kruger, and perhaps the most adamant in his negative assessment, H. U. Anderson. ${ }^{26}$ Others who take a more or less neutral position include Michael V. Fox, William P. Brown, and Roland Murphy. ${ }^{27}$ Of course, each of these assessments as to a commentator's "approach" is somewhat subjective, and can only be evaluated as a matter of degree.

${ }^{24}$ Iain Provan, Ecclesiastes/Song of Songs, NIV Application Commentary (Grand Rapids: Zondervan, 2001); Daniel C. Fredericks, Coping with Transience: Ecclesiastes on Brevity in Life, Biblical Seminar 18. (Sheffield, England: JSOT Press, 1993); Kathleen A. Farmer, Who Knows What Is Good? A Commentary on the Books of Proverbs and Ecclesiastes, International Theological Commentary (Grand Rapids: Eerdmans, 1991); R. N. Whybray, Ecclesiastes (Sheffield, England: Sheffield Academic Press, 1989); Elsa Tamez, When Horizons Close: Rereading Ecclesiastes (Winona Lake, IN: Eisenbruans, 2006); Duane A. Garrett, Proverbs, Ecclesiastes, Song of Songs, New American Commentary (Nashville: Broadman, 1993); Robert Gordis, Koheleth, the Man and His World: A Study of Ecclesiastes, ${ }^{\text {rd }}$ augmented edition (New York: Schocken Books, 1968); Choon-Leong Seow, Ecclesiastes, Anchor Bible (New York: Doubleday, 1997); Eunny P. Lee, The Vitality of Enjoyment in Qohelet's Theological Rhetoric (Berlin, Germany: Walter de Gruyter, 2005); Walter C. Kaiser, Ecclesiastes: Total Life (Chicago: Moody Press, 1979). See also Hagia Hildegard Witzenrath, Suss ist das Licht: eine literaturwissenschaftliche Untersuchung zu Koh 11,7-12,7 (St. Ottiliten: EOS Verlag, 1979). An analysis of each author's primary assessment and contribution will be undertaken in an informal fashion throughout the contents of this dissertation. This includes those authors whose approaches are deemed as positive, negative, and neutral.

25 Jeffrey Meyers, $A$ Table in the Mist: Meditations on Ecclesiastes (Monroe, Louisiana: Athanasius Press, 2006); Ray Waddle, Against the Grain: Unconditional Wisdom from Ecclesiastes (Nashville: Upper Room Books, 2005).

${ }^{26}$ James L. Crenshaw, Ecclesiastes, The Old Testament Library (Philadelphia: Westminster, 1987); Michael A. Eaton, Ecclesiastes: An Introduction and Commentary, Tyndale Old Testament Commentaries ( Downers Grove, IL: Intervarsity, 1983); Derek Kidner, The Message of Ecclesiastes: A Time to Mourn, and a Time to Dance (Downers Grove, IL: Intervarsity, 1976); Tremper Longman III, The Book of Ecclesiastes, The New International Commentary on the Old Testament (Grand Rapids: Eerdmans, 1998); Thomas Kruger, Qoheleth, Hermeneia - A Critical and Historical Commentary on the Bible (Minneapolis: Fortress Press, 2004); H. U. Anderson, Qoheleth and Its Pessimistic Theology: Hermeneutical Struggles in Wisdom Literature (Lewiston, New York: Edwin Mellen, 1997).

${ }^{27}$ Michael V. Fox, A Time to Tear Down and A Time to Build Up: A Rereading of Ecclesiastes (Grand Rapids: Eerdmans, 1999); William P. Brown, Ecclesiastes, Interpretation (Louisville: John Knox Press, 2000); Roland, Murphy, Ecclesiastes, Word Biblical Commentary, vol. 23a (Nashville: Thomas Nelson, 1992). 
While most commentators can be evaluated as taking a generally optimistic or pessimistic approach to Qohelet, some more recent commentators have produced works that approach Qohelet in ways that can only be described as unique. Those who are categorized as providing unique contributions include Martin A. Shields, Mary E. Mills, T. A. Perry, Doug Ingram, Douglas Miller, and on a popular level, radio teacher Richard DeHaan. ${ }^{28}$ Perhaps the most radical understanding of Qohelet is that of Frank Zimmerman, who views Qohelet as a struggling homosexual! ${ }^{29}$ When one considers the breadth of opinion regarding how the specifics within Qohelet are to be approached, or when one brings into the fold contributions made to unique issues by way of journal articles and lesser monographs, then the list of "peculiar" contributions made by authors and scholars becomes much larger than that which is listed above.

Beyond the general distinctions made above, a survey of current approaches to Qohelet demonstrates an even wider range of scholarly opinion when one seeks to categorize approaches in a more specific manner; indeed, the list of approaches may be as long as the list of commentators themselves. All of this reveals a tendency in approaches towards imbalance, inconsistency, and unilateral interpretation to the exclusion of significant thematic elements. Although most commentators would with little doubt deny that their own approach lacks consistency and balance, there nevertheless exists a natural tendency within scholarship to call attention to one or two thematic or exegetical "keys"

${ }^{28}$ Martin A. Shields, The End of Wisdom: A Reappraisal of the Historical and Canonical Function of Ecclesiastes, (Winona Lake, IN: Eisenbrauns, 2006); Mary E. Mills, Reading Ecclesiastes: $A$ Literary and Cultural Exegesis (Aldershot, England: Ashgate Publishing Limited, 2003); T. A. Perry, Dialogues with Kohelet (University Park, Pennsylvania: The Pennsylvania State University Press, 1993); Doug Ingram, Ambiguity in Ecclesiastes, Library of Hebrew Bible/ Old Testament Studies (New York: T\&T Clark, 2006); Douglas B. Miller, Symbol and Rhetoric in Ecclesiastes: The Place of Hebel in Qohelet's Work (Atlanta: Society of Biblical Literature, 2002); Richard W. DeHaan, The Art of Staying Off Dead-End Streets (Wheaton, IL: Victor Books, 1974).

\footnotetext{
${ }^{29}$ Frank Zimmermann, The Inner World of Qohelet (New York: KTAV Publishing House, 1973).
} 
in unlocking the mysteries of Qohelet. For example, in surveying commentators who take a positive approach, one finds little consensus as to what the primary message of Qohelet really entails, what the key exegetical or thematic clues are in arriving at such a message, and to whom the message should be directed. As to primary message, authors such as Whybray, Gordis, Seow and Lee focus on the enjoyment of life as the primary message of Qohelet. ${ }^{30}$ Others such as Garrett and Fredericks recognize a core anthropological message in the book, while Provan takes a more theocentric approach to the book. ${ }^{31}$ As to exegetical keys, Farmer views the key to Qohelet in the use of question framed throughout the text, most notably in $6: 12$, "Who knows what is good for humankind?"32 Others see a "zwar-aber" embracing of thematic tension as the key hermeneutical clue to the text, while most would suggest a particular understanding of the key word "hevel" as the exegetical crux to the book. ${ }^{33}$ In any case, as suggested above, even among those

\footnotetext{
${ }^{30}$ In spite of a wide breadth of scholarly research and contributions into Qohelet studies, R. N. Whybray is perhaps best known in the world of Qohelet studies as popularizing the centrality of the "enjoy life" motif through his article, "Qoheleth, Preacher of Joy," JSOT 23 (1982): 87-98. Robert Gordis approaches the book from the premise that "the basic theme of the book is its insistence upon the enjoyment of life, of all the good things in the world", and that "to enjoy life is therefore the only commandment of which man may be certain; to fail to obey it is to be a sinner before God." See Gordis, Koheleth, 124-25. Seow does balance the enjoyment of life with the recognition of life's "ridiculous situation," namely, the injunction to enjoy life in the midst of dire circumstances. See Seow, Ecclesiastes, 58. Perhaps Lee takes the most balanced approach to the "enjoy life" message, coupling the enjoyment of life with the fear of God so as to "do justice to both the subversive and constructive value of the book." See Lee, The Vitality of Enjoyment, 7-9.

${ }^{31}$ Garrett and Fredericks are in agreement in that they both recognize a central emphasis on the mortality of mankind and the fleeting nature of mortal existence. See Garrett, Proverbs, Ecclesiaistes, Song of Songs, 278 and Fredericks, Coping with Transience, 32. Also, it is worth noting that Provan, while certainly acknowledging an anthropological perspective to the book, chooses rather to emphasize the theocentric motifs in Qohelet, presenting the "otherness" of the divine and the utter mockery of human attempts to obtain divine insight and knowledge. See Provan, Ecclesiastes/Song of Songs, 38-39.

${ }^{32}$ Farmer, Who Knows What is Good?, 151.

${ }^{33}$ The "zwar-aber" approach to contradiction and tension is a key hermeneutical consideration in the approach of R.N. Whybray, Ecclesiastes, 39, although it first appeared in the work of H.W. Hertzberg, Der Prediger (Gutersloh: Mohn, 1963), 30-31. The argument is structured in such a way that Qohelet first states a proposition with which he agrees in general terms (zwar means 'admittedly' or 'It is true that... '), but then (aber, 'but') proceeds to disqualify it by another consideration which largely deprives it of its
} 
scholars who take a positive approach to the message of Qohelet, there is little consensus regarding the particulars of how one arrives at or understands that "positive" approach.

In the same sense, when surveying those who take a negative approach, one finds little true consensus regarding the message, history, and genre of the book, especially when the nuanced particulars are explored. ${ }^{34}$ The same could be said for the more balanced writers; even though balanced in approach, there is little true consensus as to the particulars. It too goes without saying that those with more or less "unique" and "peculiar" contributions would not find consensus of agreement on almost any of the particulars or generalities regarding Qohelet's message and intent. ${ }^{35}$

\section{The Need for Balance in Approaching the Book of Qohelet}

A balanced approach to Qohelet must view the text as a literary whole, understanding enigma, contradiction, and tension as a literary tool revealing in and through the text the very world in which the author exists. A shift has already occurred in scholarship away from the traditional concerns of historical criticism in reconstructing the "real Qohelet" behind the text and towards the less speculative and therefore more rewarding goal of rhetorical criticism. As literary compositions, the poetics of wisdom literature, and

force. As to the issue of the key term הבל , almost all scholars have some approach to and understanding of the role that this key term plays in Qohelet, along with its semantic function and lexical definition in Qohelet. However, some have placed a special emphasis on the role of הבל in Qohelet; included among those are D.C. Fredericks, Coping with Transience and Douglas Miller, Symbol and Rhetoric in Ecclesiastes.

${ }^{34}$ The typical negative approach will view the main text of Qohelet as a "wisdom foil," which only functions as such when understood in juxtaposition with the positive message of the epilogue. For a brief introduction to "wisdom foil" as a hermeneutical approach to Qohelet, see Gordon D. Fee and Douglas Stuart, How to Read the Bible for All Its Worth, $2^{\text {nd }}$ ed. (Grand Rapids: Zondervan, 1993), 212-15.

${ }^{35}$ Examples of such peculiar approaches include that of Martin A. Shields, The End of Wisdom, where Qohelet functions as a foil at the canonical level, demonstrating the inadequacy of human wisdom (and wisdom literature) in the face of revelation proper. Also of note are numerous post-modern readings of Qohelet, the most intriguing of such being that of Doug Ingram, Ambiguity in Ecclesiastes, where the intentional ambiguity of the text functions as a literary device revealing the ambiguity of the world. 
therefore of Qohelet, must take front stage in developing a balanced approach to the often repeated, highly enigmatic, and sometimes contradictory motifs observable within the text itself. For instance, in reference to one aspect of rhetorical criticism, Bartholomew writes:

Repetition, for example, is a significant characteristic of Ecclesiastes. Most significant are the repetitions of the hebel (vanity) conclusion and the joy/carpe diem passages. From one angle the history of the interpretation of Ecclesiastes is a sustained attempt to level the book to one or the other of these two poles. Either the joy passages are made subsidiary to the negative hebel conclusion, or the hebel passages are made subsidiary to the joy conclusion. The crucial question is how the hebel passages relate to the joy passages. ${ }^{36}$

The above quote not only demonstrates the importance of rhetorical criticism over historical criticism in developing a text based approach to Qohelet, it also draws attention to the most pressing need in developing a balanced approach to Qohelet, that is, the need to discover the relationship of various motifs repeated throughout the text, not in a contradictory role, but rather, in a complimentary, inter-dependant role. ${ }^{37}$ To this end we will strive in the thesis, development, and conclusion of this dissertation. ${ }^{38}$

\footnotetext{
${ }^{36}$ Bartholomew, Dictionary for the Theological Interpretation of the Bible, 184.
}

${ }^{37}$ In examining the various motifs within Qohelet, the relationships between motifs are at times complex, and are better described as apples to oranges, not apples to apples. For instance, the הבל motif is foundational, while the enjoyment of life and the fear of God are derived conclusions drawn from the application of wisdom to the matter at hand. Nevertheless, one ought to find relational correspondence between the prominent motifs within Qohelet, even if their function within the line of argument differs between motifs.

${ }^{38}$ While it may be true that I am beginning with the presupposition that the prominent motifs observable within the text should in fact complement one another, I do think that such an assumption is in the end supported by an analysis of the data. Furthermore, this presupposition largely stems from the assumption that if compositional unity can be established, then one ought to assume thematic unity, even among subsidiary relationships between motifs (that is, those subsidiary relationships that are intended by the author). 


\section{The Question of Contradiction and Tension in Qohelet}

While it is beyond the scope of this introduction to take into full consideration the poetics of Qohelet (this will be done in a more comprehensive manner throughout the dissertation $),{ }^{39}$ it is pertinent at this time to evaluate in some detail the issue of contradiction and tension within the book of Qohelet. ${ }^{40}$ In the development of a balanced approach to Qohelet, one of the primary hurdles to reconcile lies in the observation of contradiction and tension between repeated thematic elements within the text. ${ }^{41}$ The historical critical approach to this issue has traditionally been to absolve tension by attributing apparent contradictions and inconsistencies to pious redactors, interpolations, multiple sources, multiple speakers and expanded annotations. ${ }^{42}$ However, by embracing the tension within the text rather than seeking to absolve it, one finds that literary/rhetorical explanations are equally plausible and far less speculative than those offered by the historical critical approaches. ${ }^{43}$ Furthermore, one finds that tension does not need to be absolved by pitting one motif against another or subjugating one motif to a

39 On the issue of "poetics" as a means to convey meaning across literary genre, see Adele Berlin, Poetics and Interpretation of Biblical Narrative (Sheffield, England: Almond, 1983).

${ }^{40}$ For a thorough survey of various approaches to the issue of contradiction in Qohelet, see Michael V. Fox, Qohelet and His Contradictions, JSOTSup 71 (Sheffield, England: Almond, 1989), 19-28.

${ }^{41}$ Apparent tension and contradiction has historically served as one basis (among others) for the rejection of authorial unity and integrity in the development of the text of Qohelet. While the issue of authorship is important, at this point the focus upon tension and contradiction exists for the purpose of developing an appreciation for tension as a literary device in the rhetoric of Qohelet.

${ }^{42}$ Seow, Ecclesiastes, 39.

${ }^{43}$ Many scholars have been quick to point out the difficulties of conceding to a redactional explanation for the contradictions within Qohelet. Far from absolving the difficulties of the text, the redactional approach only creates new problems, fails to explain thematic tension, and falls short in recreating a congruent primary text. As Fox observes: "(a) the elimination of the putative additions more often than not leaves syntactical and logical gaps in the text, (b) the supposed glosses do not fulfill their alleged purposes, (c) the glossators have failed inasmuch as the skeptical or pessimistic character remains blatant, and (d) excising does not result in consistency." See Fox, Qohelet and His Contradictions, 24-25. 
subsidiary position while elevating another to prominence. When thematic tension is recognized as an essential literary device depicting reality, the reader begins to approach life with a realistic wisdom that addresses the world as it really exists. ${ }^{44}$

Apparent internal inconsistencies have been long recognized by readers of Qohelet, ${ }^{45}$ but it is only recently that these inconsistencies have been entertained as being elemental to a positive reading of the book (a reading that does not see tension or contradiction as an essential aspect of playing off the "wisdom foil"). Inconsistencies within Qohelet apply to thematic elements as well as particular statements. Furthermore, contradictions need not refer only to "violations of the canons of logic," but may also refer to "unresolved tensions between incongruous and incompatible observations," those observations and experiences that constitute a "violation of sensibilities," and not just a violation of logic. ${ }^{46}$ Examples of contradiction and tension include a number of inconsistent, and by certain estimations, diametrically opposed points of view: wisdom is praised for its value $(2: 13-14 ; 7: 11,19 ; 8: 1 ; 9: 16-18 ; 10: 10,12)$, yet denigrated in value $(1: 17-18 ; 2: 15-16 ; 6: 8,10: 1)$; pleasure is questioned as to its value $(2: 2-3,10-11)$ yet joy

\footnotetext{
${ }^{44}$ Regarding the strategy and structure of tension in the text, Estes writes, "The unusual structural arrangement of Ecclesiastes is not arbitrary; it is an essential component of the writer's strategy. As a text that is far more poetic than prosaic, Ecclesiastes does not merely report the author's experience to the reader; rather, it endeavors to re-create vicariously the experience of the author to the reader, thus teaching the reader how to think, as well as what to think" (citing Hill and Walton, 369). See Daniel J. Estes, Handbook on the Wisdom Books and Psalms (Grand Rapids: Baker Academic, 2005), 279 and Andrew E. Hill and John H. Walton, A Survey of the Old Testament, $2^{\text {nd }}$ ed. (Grand Rapids: Zondervan, 2000 ), 369.

${ }^{45}$ According to Fox, "one of the first reported discussions of Qohelet centers on the book's contradictions." The discussion is as follows: "The sages sought to withdraw the book of Qohelet because its words are mutually contradictory. Why then did they not withdraw it? Because it begins with words of Torah and it ends with words of Torah (b. Shab. 30b)." See Fox, A Time to Tear Down, 1 and Seow, Ecclesiastes, 39.

${ }^{46}$ Fox, A Time to Tear Down, 3. For Fox, it is important to understand that these "contradictions" are as much a matter of feeling as they are a matter of reality. To this extent, "absurdity" (as he defined Qohelet's use of הבל), constitutes an emotional component in addition to its description of reality.
} 
is commended throughout the book $(2: 24-26 ; 3: 12-13 ; 3: 22 ; 5: 18-20$ [Hebrew 17-19];

$8: 15 ; 9: 7-9 ; 11: 9)$; Qohelet claims to hate life $(2: 17)$, yet affirms life $(9: 4-6 ; 11: 7)$; wealth is deemed as good $(5: 8 ; 6: 8 ; 7: 11 ; 9: 16)$ and evil $(5: 9-14)$; God refrains from intervention $(8: 10,14,17 ; 9: 2-3)$ yet acts in judgment $(3: 17 ; 5: 6$ [Hebrew 5$] ; 8: 12-13 ; 11: 9) .{ }^{47}$

Discerning contradiction is often in the eye of the beholder, and certainly some apparent contradictions are easily resolved with semantic precision and attention to context; nevertheless, a balanced reading of Qohelet must tackle the issue of contradiction and tension head on. ${ }^{48}$

Beyond the speculations of redaction and source criticism, scholars have presented numerous explanations for tension and contradiction in the text. For instance, the biographical model explains contradictory statements through the thesis that the book of Qohelet was "composed of texts that were written by one and the same author at different times in different 'moods' and from different 'points of view." "49 A biographical approach may assume a chronological basis (that the tensions observed within the text result from "the fruit of a lifetime's research," the idea is that Qohelet as an author and a sage is entitled to different points of view, even

${ }^{47}$ Kruger, Qoheleth, 14; citing Adolf Gerson, Der Chacham Kohelet als Philosoph und Politiker: Ein Kommentar zum biblischen Buche Kohelet, zugleich eine Studie zur religiosen und politischen Entwicklung des Volkes Israel im Zeitalter Herodes des Grossen (Frankfurt am Main: Kauffmann, 1905), 16-17; Seow, Ecclesiastes, 39; Farmer, The Hebrew Bible Today, 140.

${ }^{48}$ For example, one should be careful to discern between Qohelet's understanding of pleasure in chapter 2 and joy in the oft repeated "enjoyment of life" refrains, or between the context of his "hatred for life" indictment (2:17) and the various points where he affirms the value of life, especially in the sense of carpe diem $(9: 7-10 ; 11: 9)$. On the distinction between joy and pleasure in Qohelet, see Lee, Vitality, 34.

${ }^{49}$ Kruger, Qoheleth, 14-15.

${ }^{50}$ Regarding his approach to tension, Crenshaw states, "I believe the tensions of the book represent for the most part the fruit of a lifetime's research." Indeed, as circumstances change and as contexts differ, the response demanded may also fluctuate. See Crenshaw, Ecclesiastes, 48-49. 
on the same topic based in the same text. There is some value to this approach; even if a chronological, "biographical" assessment is unnecessary, one should certainly consider the impact of context in ascertaining one's observations, reflections, and assessment of reality.

Others account for tension and contradiction by assuming that the text of Qohelet reflects multiple speakers. Proposed variations on the multiple speaker theory include those which read Qohelet as a debate between a wise man and a fool and those which see in play a broader forum of compiled opinions of sapiential concern. Of particular interest in contemporary scholarship is the proposal of T. A. Perry, who views the text as a transcript of a debate between two main voices: Kohelet, the "man of experience," and the Presenter, the "man of faith." ${ }^{51}$ By framing Kohelet as the voice of pessimism and the Presenter as the voice of piety, Perry explains the tension of the text as a literary depiction of the "debate technique," a device similar in style to the midrashic reading techniques of rabbinic Judaism. As intriguing as they may be, the difficulty with multiple speaker theories, however, is that they are formed on the same speculative basis as that of source, form, and redaction criticism. The only difference is that the prejudice of redaction critics is largely historical while that of the multiple speaker proponents is largely exegetical. ${ }^{52}$

Most contemporary commentators taking an essentially unified view towards authorship have proposed some variation of a "deliberately dialectical" approach to

${ }^{51}$ T. A. Perry, Dialogues with Kohelet (University Park, Pennsylvania: The Pennsylvania State University Press, 1993).

${ }^{52}$ For instance, Perry must determine the speaker based upon perceived pessimism and piety, but his assessment of each is too often subjugated to his thesis rather than to conventional exegetical influences. 
tension in Qohelet. ${ }^{53}$ Some have construed rather complex approaches to this problem, such as the proposal of "polar structures" in the work of J. A. Loader. ${ }^{54}$ Others resolve the difficulties with a "zwar/aber" approach to tension, an approach that has much to commend itself. ${ }^{55}$ Nevertheless, while literary style and the rhetoric of poetry plays a tremendous role in enabling one to come to an acceptable resolution to the problem of tension in Qohelet, the best approaches to this dilemma are the rather uncomplicated ones which embrace tension as an accurate depiction of life so far as a wise man would observe it. $^{56}$

Foremost among those who embrace tension as essential to the understanding of Qohelet is Michael Fox, who tackles Qohelet's contradictions as "the starting point of interpretation." ${ }^{, 57}$ His thesis is a self proclaimed "simple one": "The contradictions in the book of Qohelet are real and intended. We must interpret them, not eliminate them." 58

Such a view has much to contribute: it retains the unity, integrity, and harmony of the line of argument in Qohelet, while also reflecting a literary representation of the very

\footnotetext{
${ }^{53}$ Farmer, Who Knows What is Good?, 140.
}

${ }^{54}$ J. A. Loader, Polar Structures in the Book of Qohelet (Berlin/New York: de Gruyter, 1979). Loader proposes that the tensions in the text are intentional "polar structures," whereas in any given text mutually contradictory points are related to each other within a text in such a manner that both are equally valid. Equal validity between mutually contradictory statements is reflective of the programmatic הבל statements and observations. Loader's approach is similar to others who view tension as reflective of הבל הב; his contribution is in the length to which he has structured tension at the literary level.

${ }^{55}$ Those who embrace such an approach include Kathleen Farmer and R. N. Whybray. The "yes, but" style of internal dialogue brings to bear the non-absolute nature of the many propositions inherent in sapiential circles.

${ }^{56}$ As Seow correctly observes, the evidence of tension in Qohelet's observations are fully in line with one of his main points: "that the real world is full of inconsistencies and even flagrant contradictions that cannot be explained away." See Seow, Ecclesiastes, 41.

\footnotetext{
${ }^{57}$ Fox, A Time to Tear Down, 3.

58 Ibid.
} 
world in which Qohelet ponders the "hevelness" of it all! ${ }^{59}$ Furthermore, the tension seen within the text not only reflects upon a world that is far too complicated to be systematically arranged, but it also encourages the reader to reflect critically upon the world that surrounds them. ${ }^{60}$ Indeed, the world of Qohelet is the same intensely complex, enigmatic, and as some would suggest, ambiguous, ${ }^{61}$ world in which the reader lives. Therefore, an honest reading of Qohelet will embrace the tension of the text rather than seek to eliminate it, not because tension is palatable to those who seek to systematize and control the variables of life, but because the quest of Qohelet is one steeped in a realism that reflects upon a world full of the same tensions highlighted by the text.

\section{The Question of Genre, Authorship, and Date within the Book of Qohelet}

Pertaining to introductory issues, the same lack of consensus exists within Qohelet studies as it does regarding the general approach to the book. Scholars have long debated the particulars of genre, authorship, date, integrity, and canon, even prior to the critical era. ${ }^{62}$ It must be stated from the outset that diversity exists even among scholars of the

${ }^{59}$ While the character, definition, and importance of the key word chapter 2, suffice it to say that the world, events, and circumstances that are described as הבל are depicting a wide range of meaning including concepts like enigma, absurdity, incomprehensibility, ambiguity, and the general concepts which are depicted in experiential and observable tension. Used adjectivally, I am drawing attention to the world as Qohelet would describe it, a world that is characterized by the tension that he reveals by the text. As Berger observes, "In this sense the book is itself an instantiation of the vapour; the הבל, that Qohelet detects in the universe." See Benjamin Lyle Berger, "Qohelet and the Exigencies of the Absurd," Biblical Interpretation 9 (2001): 141.

${ }^{60}$ Kruger, Qoheleth, 18.

${ }^{61}$ For an excellent treatment on the function of ambiguity in the text of Qohelet, and especially at the hermeneutical level in which tension is encountered, see Ingram, Ambiguity in Ecclesiastes.

${ }^{62}$ While early Jewish debates centered primarily around questions of canon and influence rather than authorship, questions regarding the Solomonic authorship of Qohelet do have a pre-critical history beginning with Luther but most clearly stated in the words of Hugo Grotius (1644): "I do not believe that [the book of Qoheleth] is from Solomon." See Fredericks, Qohelet's Language: Re-evaluating its Nature and Date, 1; Bianchi, "The Language of Qoheleth," 210-11. 
same theological and ecclesiastical ilk regarding introductory issues, and most scholars will admit that their conclusions are at best tentative when reconstructing the setting, date, and circumstances of authorship pertaining to the origin of the book of Qohelet. ${ }^{63}$

In the following treatment of introductory issues, the particulars will be examined in conjunction with one another, as matters regarding genre, authorship, and date are intricately related. In a broad sense, most positions regarding introductory matters can be divided among three categories: (a) those which view authorship and textual development through multiple, redactional, non-Solominic, late authorship, (b) those which view matters of development as late, non-Solomonic, but unified in authorship and integrity, and (c) those which hold to a Solomonic, unified, and early perspective on authorship and development.

Critical scholarship has for the last two centuries assumed an early, source critical, redaction based history of development for Qohelet. Aside from critical presuppositions, the criteria for these general assumptions are primarily based on linguistic grounds and speculation regarding the socio-political context behind the book. Modern critical scholarship is forced to accept by the advent of the discovery of the Dead Sea Scrolls a "terminus ad quem" for the finishing of the book no later than 175 to $150 \mathrm{~B}$. C. $E{ }^{64}$ with the general assumption in "recent scholarship" supporting a date of origin

\footnotetext{
${ }^{63}$ The history of conservatives accepting non-Solomonic authorship on various grounds is well attested. While it is of no surprise that critical scholars such as G. A. Barton would describe the notion of Solomonic authorship as "unthinkable," it is noteworthy that relatively conservative scholars too have made bold assertions regarding the implausibility of Solomonic authorship, perhaps the best known coming from the pen of F. Delitzsch, "If the book of Koheleth were of old Solomonic origin, then there is no history of the Hebrew language." See G. A. Barton, Ecclesiastes, 58-59 and F. Delitzsch, Ecclesiastes, reprint of English ed. (Grand Rapids: Eerdmans, 1982), 190.

${ }^{64}$ See Kruger, Qoheleth, 19; 36-37; Fredericks, Qohelet's Language, 2; J. Muilenberg, “A Qoheleth Scroll from Qumran," BASOR 135 (1954): 20-28; and Murphy, Ecclesiastes, xxiv. Of the two
} 
between 250 and 200 B. C. E. ${ }^{65}$ However, the pre-Maccabean, post-exilic date of origin is not the exclusive domain of source critical scholarship. Today, a number of scholars now support a unified, yet non-Solomonic, post-exilic theory in dating Qohelet. ${ }^{66}$ Because these scholars accept the textual integrity and inspirational authority in spite of a nonSolomonic, post-exilic date, it is to their rationale that we now turn.

As previously noted, those who hold to a non-Solomonic, late date of authorship and origin typically do so based upon linguistic and socio-political rationale, all the while further supporting their case through the recognition of specific genre related characteristics inherent in the text. Linguistic rationale generally centers on the supposedly late nature of the Hebrew text of Qohelet, with special attention given to its affinity to Mishnaic Hebrew over against biblical Hebrew, the reflection of "Aramaisms" within the text, linguistic particularities reflecting Phoenician influence, and perhaps most significantly, the existence of Persian loanwords in the text. ${ }^{67}$ For instance, pointing to a combination of frequent Aramaisms and Persian loanwords, Seow demands a date of

Hebrew Qumran fragments, one is dated between the mid-first century and the early first century B. C. E. and the other between 175 and 150 B. C. E.

${ }^{65}$ Kruger, Qoheleth, 19.

${ }^{66}$ Prominent scholars affirming an essentially unified yet late, non-Solomonic Qohelet include Choon-Leong Seow, Iain Provan, Tremper Longman III, Michael Eaton, Kathleen Farmer, R. N. Whybray, R. K. Harrison, Derek Kidner and Roland Murphy.

${ }^{67}$ On the question of dating Qohelet according to language, the most comprehensive treatments of this issue must be those by Antoon Schoors, who concludes in favor of a post-exilic date of origin, and D. C. Fredericks, who argues in favor of a pre-exilic date of origin. See Antoon Schoors, The Preacher Sought to Find Pleasing Words: A Study in the Language of Qoheleth, OLA 41 (Leuven: Peeters, 1992); idem, The Preacher Sought to Find Pleasing Words: A Study in the Language of Qoheleth, OLA 143 (Leuven: Peeters, 2004); and Fredericks, Qoheleth's Language. For linguistic support in favor of Solominic authorship, see also Gleason L. Archer, "The Linguistic Evidence for the Date of 'Ecclesiastes," JETS 12 (1969): 167-81. For arguments dating Qohelet on Mishnaic characteristics within the Hebrew of Qohelet, see Delitzsch, 190-96; Schoors, Preacher Part 1, 221-22. On Phoenician influence, see especially the studies of M. H. Dahood, "Canaanite-Phoenician Influence in Qoheleth," Bib 33 (1952): 30-52, 191-221; idem, "The Language of Qoheleth," $C B Q 14$ (1952): 227-32; idem, The Phoenician Background of Qoheleth," Bib 47 (1966): 264-82. 
origin "sometime between the second half of the fifth and the first half of the fourth centuries B. C. E." ${ }^{68}$ Socio-political rationale is also used in support of a post-exilic date, with various scholars hypothesizing the particulars of an implied commercial economy to establish a background in the context of the Persian or Greek period of Jewish history. ${ }^{69}$ While some scholars are reluctant to pinpoint the precise historical period from which Qohelet originates, many scholars have nevertheless postulated a comparison of vague allusions to historical referents with striking abandon. ${ }^{70}$ Such an endeavor, however, is so speculative as to bring little consensus among scholars regarding historical generalities, much less particulars. ${ }^{71}$

Scholars adhering to a post-exilic, non-Solomonic date rely not only upon external lines of evidence, but they also find internal support within the text itself. Of particular interest are verses that result in logical difficulties when applied to the historical Solomon. For example, in recounting his quest in the first person, Qohelet uses the perfect tense in 1:12, "I, Qohelet, was (היית) king over Israel in Jerusalem." However,

\footnotetext{
${ }^{68}$ Seow, Ecclesiastes, 12-20; 36-39. The two Persian loanwords in question are "garden") from 2:5 and ("decree") from 8:11.

${ }^{69}$ Seow describes the period as "one of economic vitality but also volatility. It was a time for heady optimism about hitherto unimaginable opportunities tempered by sociopolitical and economic realities. It was a perplexing new world of rapid political, social, and economic innovations, many of which were initiated and determined in seats of power that the ordinary citizens of the vast empire could hardly grasp." See Seow, “Theology When Everything Is out of Control," Interpretation 55(2001): 245. The obvious problem with general descriptions such as this one is that they can too easily be applied to many historical periods and events. The problem with more specific allusions is that they are so highly speculative.

${ }^{70}$ For instance, critical scholar G. A. Barton claims that the "wise youth" of Eccl 4:13 was a reference to the rise of Ptolemy V, who came to power in 205 B. C. E.; see G. A. Barton, Ecclesiastes, 120. In similar fashion, Delitzsch argues that Eccl 6:3 alludes to Artaxerxes II and Artaxerxes III (note however that history is rife with kings dying without lamentation, Israel's history being no exception); see Delitzsch, 214-15.

${ }^{71}$ For a comprehensive examination of the socio-political background of Qohelet, see C. Robert Harrison, "Qohelth in Socio-historical Perspective" (Ph.D. diss., Duke University, 1991).
} 
according to 1 Kings 11 , Solomon died while he ruled Israel, thus creating some difficulty for those who would hold to Solomonic authorship. ${ }^{72}$ Qohelet $1: 16$ a is equally awkward from the pen of Solomon: I said to myself, "I have surpassed in wisdom everyone who ruled Jerusalem before me." While Solomon's wisdom as an Israelite king is legendary, the only one to rule in Jerusalem before him was his father David, against whom he would likely not compare himself, much less do so in the superlative. ${ }^{73}$ Furthermore, beyond the first two chapters the allusions to Solomonic authorship diminish, and the perspective of the writer, while familiar with royalty, seems to be biased against the establishment, not a part of it. ${ }^{74}$

In spite of the overwhelming support among scholars for non-Solomonic authorship, some prominent scholars have argued for a pre-exilic date of origin, if not for Solomonic authorship itself. ${ }^{75}$ As previously stated, the external linguistic and sociopolitical lines of evidence are highly speculative and have resulted in little consensus regarding the particulars, opening the door to pre-exilic alternatives that provide sensible

\footnotetext{
${ }^{72}$ Longman sees the use of the past tense in a first person account as an "implicit claim that there was a time when Solomon was alive but no longer king." By this allusion to non-biblical history the Targum creates a legend that Solomon abdicated his throne in his old age, thus allowing for a period in which he could claim kingship in the past tense. See Longman, Ecclesiastes, 5.

${ }^{73}$ Of course, Jebusite kings ruled in Jerusalem prior to David or Solomon, but it would seem equally strange for Solomon to compare himself in wisdom to the pagan rulers who were hostile to the people and to the God of Israel.

${ }^{74}$ Common allusions to a non-royal perspective include those in 4:1-3 (could not Solomon have done anything to curtail oppression, or better yet, was not Solomon guilty of causing oppression among the people [1 Kings 12:4]?); 5:8-9 [Hebrew 5:7-8]; and 8:1-9.

${ }^{75}$ Scholars supporting Solomonic authorship include Walter Kaiser, Jeffrey Meyers, Duane Garrett, Roy Zuck, J. Stafford Wright, Louis Goldberg, Donald R. Glenn, and Gleason L. Archer. Others such as D. C. Fredericks and William H. U. Anderson argue in support of pre-exilic origin, yet are less dogmatic in reference to Solomonic authorship. Finally, others such as Daniel Estes choose to remain (perhaps wisely) ambiguous on the issue.
} 
options that answer for the evidence. ${ }^{76}$ As for the internally based arguments against

Solomonic authorship, these too have been explained in favor of a pre-exilic origin by exploring the use of literary technique within the text. For instance, the English translations reflective of the past tense in 1:12 are exegetically interpretive; the Hebrew perfect might better be translated "I have been king," thus implying an ongoing situation rather than a terminated status. ${ }^{77}$ The logical difficulties of Solomon recalling his wisdom as surpassing "all who ruled in Jerusalem before him" can be answered by noting that presumably wise kings did rule in Salem prior to David, including prominent figures such as Melchizedek (Gen 14:18), Adonizedek (Josh 10:1), and Araunah (1 Sam 24:23). ${ }^{78}$ As for reflections critical of royal behavior, there is little reason to think that a wise king could not reflect critically upon the king's role or behavior. ${ }^{79}$ Furthermore, many of the same reflections on royal activity would seem awkward and contrived if set within a postexilic Judean context. The distant emperors of the Persian and Grecian empires hardly

\footnotetext{
${ }^{76}$ On linguistic evidence supporting an early Hebrew origin to the text, see Fredericks, Qoheleth's Language and Gleason L. Archer, "The Linguistic Evidence for the Date of 'Ecclesiastes," JETS 12 (1969): 167-81.

${ }^{77}$ See Qoh 1:12: (אני קהלת הייתי מלד); Garrett, Proverbs/Ecclesiastes/Song of Songs, 261. Apart from the grammatical ambiguity in the Hebrew perfect, one must also consider the influence of subtle literary technique as Solomon may have purposefully distanced himself in the same way that one would achieve distance in speaking about their own circumstances in the third person, which of course also takes place in the text of Qohelet (assuming unified authorship).

${ }^{78}$ Kaiser agrees that the existence of Canaanite kings ruling in Salem "easily cares for the issue," although it does seem unlikely that any Israelite king would have in mind pre-Israelite kings in making superlative comparisons in the arena of wisdom; Kaiser, Ecclesiastes, 28. Perhaps more convincing in favor of Solomonic authorship is the fact that 1 Kings 3:12 explicitly states that no one after Solomon would be as wise as he, thus creating difficulties if authorship is applied to a literal post-Solomonic king in Jerusalem. See Jeffrey Meyers, A Table in the Mist (Monroe, Louisiana: Athanasius, 2006), 20. It may very well be that the statement in 1:16 will remain awkward when applied to Solomonic or post-Solomonic theories of authorship, at least when understood apart from an understanding of autobiographical fiction and literary technique using Solomon to draw attention to the ultimate example of the inadequacies of wealth and wisdom.

${ }^{79}$ Garrett, Proverbs/Ecclesiastes/Song of Songs, 261.
} 
seem to fit the Hebrew depiction of royalty as implicitly described in Qohelet. Even if the text is not Solomonic in origin, the context of proximity to the king would imply a preexilic origin. ${ }^{80}$ Garrett asks an appropriate challenge to those supporting a post-exilic date: "Even the wealthy Jew of the postexilic period probably never saw a king in his life. Why then so much concern, in a book of Jewish wisdom, with how to deal with the king?" 81 Thus one discovers that based solely upon historical/critical analysis, the question of date, authorship, and background circumstances seem as elusive as the meaning of the text itself. ${ }^{82}$

Whatever evidence exists for or against Solomonic authorship, there is little doubt that the author of Qohelet sought to draw upon the image of Solomonic authorship in the opening of the book. ${ }^{83}$ In this sense, the question of authorship, the question of unity, and the question of genre become intertwined as scholars propose multi-faceted theories explaining why Solomonic imagery might be envisaged in a non-Solomonic document. ${ }^{84}$ Furthermore, scholars are forced to reckon not only with internal and external evidence for and against Solomonic authorship, but they must also address the structural

${ }^{80}$ For further arguments supporting pre-exilic, non-Solomonic options, see Anderson, Pessimistic Theology, 89-94.

${ }^{81}$ Garrett, Proverbs/Ecclesiastes/Song of Songs, 261.

${ }^{82}$ This situation is not necessarily a result of haphazard irony; Doug Ingram has strenuously argued in favor of intentional ambiguity within Qohelet, even in regard to introductory issues such as the role of authorship in the text and the identity of the figure Qohelet. See Ingram, Ambiguity, 75-90.

${ }^{83}$ Taking the notation of Solomonic allusion one step further, Meyers sees a clear connection between inspired intentions and integrity in the text's introduction, "The words of the Teacher, son of David, king in Jerusalem." Regarding this, Meyers states, "there is no way to escape the implication that the book of Ecclesiastes is being commended to the reader as the work of God's king." See Meyers, Table in the Mist, 19.

\footnotetext{
${ }^{84}$ In dealing with the issue of genre, most scholars accept that Qohelet should be classified as a form of Hebrew wisdom literature. However, the precise nature of that wisdom, as well as the literary techniques employed within Qohelet's particular brand of wisdom remains debatable.
} 
peculiarities of a text utilizing the first and third person to reference its primary character, Qohelet. $^{85}$

Furthermore, the "voices" in the text of Qohelet betray the possibility of distinct structural segments and distinctions in authorship, most notably that which exists between the person of Qohelet and that of an "epilogist" or "frame-narrator." The problem is such that Provan states the dilemma in terms that disallow Solomonic authorship aside from issues of date and integrity, but rather, in terms of genre: "Even if the speaker were Solomon (which he probably is not), the speaker is assuredly not the author of the book as it has been passed on to us. To claim otherwise would be a little like claiming that Jesus (the central and dominant 'I'-speaker), and not John (who refers to Jesus as 'he'), wrote John's Gospel." ${ }^{86}$ In much the same fashion that the gospels create a unique literary genre by way of their relationship between event, characterization, and authorship, so in Qohelet a unique situation arises in the canon.

To separate the author from the speaker does not necessarily demand multiple authorship, nor does it demand that a "Solomonic guise" be used as a literary ploy to envisage the reenactment of Solomon's reign. ${ }^{87}$ In other words, Solomon very well could be the speaker, Qohelet, even if he is not the anonymous author responsible for the literary arrangement of Qohelet's words and the theological reflection upon them. In this authorial scheme, the so called "epilogist" is not a latter redactor to Qohelet's words, but rather, he is the author of the text, one who finds his own views to be compatible with

\footnotetext{
${ }^{85}$ Not only is Qohelet referenced in both the first $(1: 12-18)$ and third person $(1: 1 ; 7: 27 ; 12: 9-14)$, but he also is referenced by the definite article in 12:8.

${ }^{86}$ Provan, Ecclesiastes/Song of Songs, 26.

${ }^{87}$ The phrase "Solomonic guise" is that of E. S. Christianson, A Time to Tell: Narrative Strategies in Ecclesiastes, JSOT 280 (Sheffield: Sheffield Academic Press, 1998), 128-72.
} 
those of the speaker Qohelet, and yet at the same time one who is distinct in person from Qohelet. This does not absolve the difficulties of working with the text, but it does explain the use of first and third person within the text, the existence of a prologue and epilogue in the text, and the sense of distinct "voices" of reflection apparent within the flow of thought throughout the book. Furthermore, such an approach to authorship allows for the distinct possibility of Solomonic participation in the text as speaker, not in the form of a literary guise, but through real identification with the person of a historical Qohelet. ${ }^{88}$ Simultaneously, the option is open to both a pre-exilic and a post-exilic period for the origin of the text in that the author remains anonymous in person and in background. ${ }^{89}$

Although scholarship has been for many years consumed by questions of introduction and the desire to recreate the person and event behind the words of the text, in the end the person of Qohelet takes second stage to the words of Qohelet. There is a sense in which the book itself seems to cast a degree of ambiguity regarding the identity of Qohelet the person, and in so doing, forces the reader to wrestle with the much more

\footnotetext{
${ }^{88}$ With this view of authorship, I have no problem allowing for the option of identifying the historical Qohelet with the historical Solomon (contra Provan). They very well may be one and the same. This helps to explain why the text introduces Qohelet as "son of David, king in Jerusalem" and further alludes to Solomon's work, wealth, and wisdom (Qoh 2:4-9).

${ }^{89}$ Various scholars have postulated a number of genre specific theories of authorship to account for the presence of first and third person voices and distinct structural elements such as the prologue and the epilogue in Qohelet. For an excellent survey and assessment of genre specific approaches to the question of multiple "voices" in Qohelet, along with parallels in ANE literature, see Michael V. Fox, $A$ Time to Tear Down, 363-77. See also Michael V. Fox, "Frame-narrative and Composition in the Book of Qohelet," HUCA 48 (1977): 83-106. Particularly noteworthy among those who have postulated variations among frame-narrator and fictional royal autobiographical approaches to questions of authorship and genre is that of Tremper Longman III in viewing Qohelet as a text reflecting characteristics of "Fictional Akkadian Autobiography". See Tremper Longman III, Ecclesiastes, 1-28; also, for a full discussion of Akkadian texts representative of this genre, see Longman, Fictional Akkadian Autobiography (Winona Lake, IN: Eisenbrauns, 1991).
} 
pressing pursuit of the text's meaning rather than the writer's identity. ${ }^{90}$ As Provan wisely observes, "It is clearly what the speaker said, however, not who he was or even when he said it, that this author wants us to understand."91 Therefore, as with other anonymous canonical works, the authority behind the inspired nature of the text lies not with the identification of the human author, but rather, with the words of the text and the God who is ultimately responsible for their being. ${ }^{92}$

\section{A Survey of Prominent Motifs Observable within Qohelet and an Inter- dependent Approach to Qohelet}

Assuming that the primary means to finding an accurate, text-centered approach to Qohelet must reside in the text itself rather than in a speculative reconstruction of the background of the book, it is at this juncture necessary to move away from introductory issues to a survey of the prominent motifs existing within the book of Qohelet. ${ }^{93}$ Recognizing that different books of the Bible call for different approaches in reading the text, one is forced to consider internal clues as to how various genre, not to mention unique books themselves, are to be read and interpreted. The internal hermeneutical clue

\footnotetext{
${ }^{90}$ On the ambiguity of the word character, see Ingram, Ambiguity, 75-90.

${ }^{91}$ In an excellent commentary upon the misguided pursuit of an event based analysis of Qohelet at the expense of a better text-centered approach, Provan states, "It is one of the great ironies of modern biblical scholarship (of whatever theological and confessional complexion) that what the originators of Old Testament tradition have thus themselves pronounced unimportant to the text, its modern readers have pronounced crucial for its understanding, expending enormous and futile effort in an attempt to trace the erased footsteps across the sands of time and exhume their alleged owner's corpses from their self-sealed tombs." For both quotes, see Provan, Ecclesiastes/Song of Songs, 30.

${ }^{92}$ For an introduction to the benefits of a text-centered approach, see John H. Sailhamer, Introduction to Old Testament Theology: A Canonical Approach (Grand Rapids: Zondervan, 1995), 36-85.

${ }^{93}$ I define the term "motif' in accordance with Jess Stein, editor in chief, Random House College Dictionary of the English Language, rev. ed. (New York: Random House, 1988), 871. Here the term is defined 1) as a recurring subject, theme, idea, etc . . or, 2) as a dominant idea or feature. The term "theme," on the other hand, refers generally to any subject or topic, without including the aspects of repetition and dominance inherent in a motif.
} 
in the text of Qohelet comes in the form of recurring motifs and their prominent role in the line of argument within the text. As one reads the text of Qohelet, one cannot help but observe a significant degree of repetition among certain recurring, prominent motifs. It is this observation that provides the hermeneutical clue in arriving at a balanced, textcentered approach to Qohelet.

The following survey is intentionally brief in that each of the prominent motifs delineated in what follows will be taken up in detail in the chapters constituting the main body of this dissertation. Therefore, the exegetical details supporting an accurate understanding of each motif, along with the relationship of each motif to the others, will await later discussion. Furthermore, the selection of those motifs deemed "prominent" is an obviously subjective process, and the author of this work recognizes that additional motifs beyond those dealt with in this dissertation are easily recognizable within the text of Qohelet. Related to each selected motif lie themes and repeated concepts that in other works may be designated as an independent motif in and of itself. However, at some point I had to make a judgment call as to which motifs were most prominent (although not necessarily co-equal in significance or in function). I fully realize that many words and concepts could accurately be labeled "motif," and I am not making the claim that the motifs that I have choosen as "prominent" are at the same time exclusive. ${ }^{94}$ Many topics and motifs are treated under the umbrella of those motifs selected as "prominent" in this work. For instance, the topic of "time" is critical in Qohelet, but I deal with that more specifically under the discussion of sovereign determinism and the imposition of limitation upon mankind (which I consider motif, in spite of the lack of a clear lexical

\footnotetext{
${ }^{94}$ My primary intent in this work is not to list all of the motifs or themes in the book of Qohelet, but rather to show that the prominent motifs do relate to one another and suggest a thematic unity to the book.
} 
point of reference). In the same way, "work" is a major theme in the book, but I treat it under the umbrella of the enjoyment of life. As a matter of fact, I deal with the relationship between work and joy in chapter 7, evaluating the key word עמל in light of the situation of and the "enjoy life" refrains. I work with a number of key words repeated within the "enjoy life" refrains, but I do not treat each of these words as a "prominent motif." At some point I simply had to make a call as to whether I should treat certain motifs independently, or under the umbrella of another. ${ }^{95}$

It is in each chapter that I detail the role and function that each motif plays in the development of Qohelet's message. It is worth noting that no two motifs play the same role, function in the same manner, or necessarily carry the same kind of influence as the other motifs. When comparing motifs, we are not necessarily comparing apples with apples. Nevertheless, I would suggest that each motif must be understood in light of the other motifs, even if we are comparing apples with oranges so far as form and function are concerned. The approach taken in the following chapters is fully aware that these motifs will differ in form and function. Nevertheless, one cannot understand Qohelet without being fully aware of how each motif influences and weighs on the others.

Among the prominent motifs treated in this dissertation, certain ones are based in ideas rather than in particular words, while others are more closely linked with a particular word or phrase. Perhaps no single word carries more prominent a role in Qohelet than the Hebrew word הבל, translated in English translations by various terms, including but not limited to "vanity," "meaningless," "fleeting," and "smoke." 
Commentators are in general agreement that this term, as used in Qohelet, plays a far more decisive role in coming to an accurate understanding of the text than any other single term or concept. Qohelet uses the word as a declaration of comprehensive

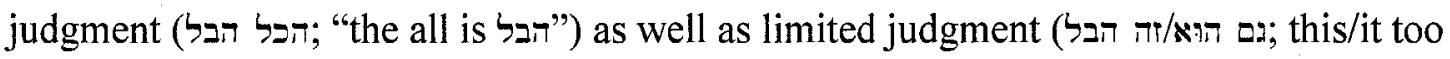
is הבל), and furthermore uses the term in the superlative in forming an inclusio to introduce and conclude the body of the main text (הבל הבלים; 1:2;12:8).

In establishing a conceptual understanding of הבל,, it is vital to assess the lexical range and function of the term as a rhetorical device in the text. This entails an examination of the term as metaphor and symbol, along with an understanding of the הבל relationship the term has with other motifs within the text (indeed, the concept of touches everything taught and examined in the book of Qohelet). ${ }^{97}$ The term as used by Qohelet has the intentional capacity to take on multiple connotations, and thus functions as a multivalent symbol of everything represented by the realities of a fallen world, with the word being used contextually to describe various aspects of that reality observed by Qohelet. In this sense the הבל motif is a descriptive foundation from which Qohelet begins his quest, namely, to discover how the wise man should live in a world that can best be described as הבל. ${ }^{98}$

\footnotetext{
${ }^{96}$ Kruger, Qoheleth, 42-43.
}

${ }^{97}$ The most detailed examination of the הבל concept as it relates to its rhetorical role and function as a metaphor and symbol is that by Douglas B. Miller, Symbol and Rhetoric in Ecclesiastes: The Place of Hebel in Qohelet's Work (Atlanta: SBL, 2002).

${ }^{98}$ Or perhaps better, by the various descriptive and judgmental nuances conveyed by the הבל symbol. Beyond simply describing the world as הבל, Qohelet seems to be seeking a solution to the "dilemma" or "חבל (gain or excess), and thus the concept of יתריון must be treated as a sub-topic as one seeks to understand the role of as a motif. 
The second prominent motif observable within Qohelet is the "under the sun" perspective from which the quest is directed. Although perhaps more of a "perspective" than a proper motif, the phrase ("under the sun") is used 29 times in reference to the activities of man as experienced in a world described as הבל. perspective implies that the observations, reflections, conclusions, and even the pursuit of Qohelet's quest were undertaken from a "horizontal" perspective, and while inspired within the canon, were not necessarily revealed by any means other than observation and existential reflection. This "motif" then has serious hermeneutical implications, as well as providing some direction regarding the content and purpose of Qohelet's quest, namely, that his goal was more pragmatic than theological, and his search was not, as commonly thought, for answers to ultimate questions of meaning and purpose in life. ${ }^{100}$

Wisdom takes on a complex role in Qohelet; in one sense, it entails the genre of the book, in another sense, it is the guiding perspective from which Qohelet is led throughout his quest, ${ }^{101}$ and finally, it functions as a motif that is explored throughout the book. Scholars have long recognized the prominent role wisdom plays in Qohelet; however, there has been little scholarly consensus on how to interpret this role. Qohelet himself does not make the task an easy one; his views regarding the value of wisdom are often set in tension so that in some contexts wisdom is denigrated as having little real

\footnotetext{
${ }^{99}$ In comparing numbers, the term הבל is used 38 times in the text, although the cancept can be derived more often than the number of cases where the explicit use of the term is found; see appendix A.

${ }^{100}$ The "under the sun" perspective also has serious implications regarding "theological context," that being understood as the context of time in which Qohelet wrote within the chronological framework of revelation. The term "theological context" is drawn from Howard G. Hendricks and William D. Hendricks, Living by the Book (Chicago: Moody, 1991), 228-29.

${ }^{101}$ Wisdom can be considered a perspective much like the "under the sun" motif is a perspective, yet the two are not in conflict with one another. In reality, wisdom, as pragmatic and practical, in many ways functions as a guiding force within the context of observations made "under the sun."
} 
value $(1: 17-18 ; 2: 15-16)$ and yet in other contexts it is seen as an advantage $(2: 13 ; 7: 11$, $19 ; 9: 16-18)$. In describing the wisdom of Qohelet, scholars have used descriptive qualifiers such as "pessimistic," "skeptic," "cynical," and "optimistic," but perhaps the best qualifying adjective would be "realistic." These options have obvious impact on how one views the wisdom motif, but at this point suffice it to say that Qohelet not only writes from the perspective of the wise, but he also writes about wisdom, and as such the concept of wisdom as evaluated in and by Qohelet entails the third prominent motif within the book.

Our fourth prominent motif is a multifaceted one that addresses the theological concerns of sapiential wisdom; namely, the determinacy of God's sovereign jurisdiction over the created world and the imposition of limitation upon fallen mankind. Within the broader framework of this motif also lies an exploration into the concept of time, circumstance, and the problem of "eternal awareness" placed in the heart of mortal man. These concerns in and of themselves do not constitute theological exploration to that end alone, but as is fitting with the thesis of inter-dependency between the motifs, the role of God and man in Qohelet is always set in context alongside of the concerns presented in the associated prominent motifs.

The fifth motif in our survey can rightly be called a proper motif if not an obsession; Qohelet's preoccupation with the inevitability of death. This motif, perhaps more than any other, has a clear connection to the others. In the sense that the judgments point toward the brevity of life and its fleeting nature, the inevitability of death provides the logical, if not ever pressing, conclusion. The timing of man's death lies solely in the hands of an inscrutable God, and man is completely unable to control with 
confidence anything regarding the circumstances or outcome of that day. Even wisdom, as valuable as it may be for the living, is impotent in effectively curtailing the eventual experience of death. Finally, in conjunction with the above, a key component of the "inevitability of death" motif is Qohelet's theology of death and his perceived openness to an afterlife with the potential for eschatological judgment. ${ }^{102}$

The final two motifs provide injunctions that bring the explorations of Qohelet to some level of conclusion; the enjoyment of life and the fear of God. Although some view the enjoyment of life as mere concession on the part of Qohelet, the prominence and position of the "enjoy life" conclusions in the text argue that these injunctions to enjoyment are essential to the message and theology of the book. In assessing the depth and content of the "enjoy life" motif, Qohelet's theology of enjoyment is set in relationship to other concepts such as work, toil, allotment, divinely appointed portion, and the role of "divine gift." Therefore, the motif of enjoyment constitutes a complex relationship of inter-dependent sub-motifs even as it requires correlation to other prominent motifs as already suggested.

Although the "fear God" motif is not as clearly delineated or as common in reference as the "enjoy life" conclusions, it is equally valid and functions as the essential balance to the "enjoy life" motif. ${ }^{103}$ Thus the fear of God drives the theological message

\footnotetext{
${ }^{102}$ It is the thesis of this dissertation that Qohelet does in fact hold to some view of eschatological judgment, presumably to take place in the afterlife. However, from the "under the sun" perspective, death appears to be the final destination of all mankind. Nevertheless, Qohelet implies, however vague, an expectation for a future period of reckoning. In this sense, it may be proposed that Qohelet functions within the canon as a theological advancement, providing hints of an afterlife not seen in other Old Testament books (Daniel 12:2 being an exception), but not fully revealed to the extent found in the New Testament. For more detail, see chapter 8 , pages $219-25$.

${ }^{103}$ It is the thesis of this dissertation that the "fear of God" motif is not the product of a "pious redactor," but rather, that this conclusion, along with the epilogue, functions as an integral and essential motif in the unified message of Qohelet.
} 
of the book in such a way that it is completely compatible with other Hebrew canonical works, even to the extent that it contributes in such a way to heighten the piety of the people of God.

\section{A Balanced Paradigm for Living: The Inter-dependency of the Prominent Motifs in Qohelet}

In presenting theories regarding the primary message of Qohelet, scholars have had a tendency to focus disproportionate attention upon one or two prominent motifs, all the while excluding the theological and exegetical contributions of equally prominent motifs. ${ }^{104}$ In this regard, there has been little consideration by the community of Qohelet scholars in taking an approach to Qohelet that evaluates all of the prominent motifs with equal consideration and importance in assessing an overall message of the book.

Furthermore, there has been little work done in evaluating each motif as an interdependent compliment to the others, exegetically understood in context one with the other. As a result, both at the academic and popular levels, there remains a propensity among authors to find imbalance and thematic favoritism between observable motifs within the book. While some have sought to find balance between particular themes, and some have furthermore interpreted select motifs in light of or in correlation with other motifs, there has not yet been a comprehensive analysis of the inter-dependency of these

\footnotetext{
${ }^{104}$ It should be noted here that such favoritism is often the result of unresolved tension and apparent contradiction observed between themes and motifs found in Qohelet. The key to balancing with equity the prominent motifs in Qohelet lies in the recognition that the tension inherent between these motifs is a reflection of the very world that Qohelet describes as הבל. As such, if one is to properly understand the observations as well as the wisdom taught in the book of Qohelet, one must learn to embrace the tension within the text rather than seek to absolve it through disproportionate weighting of the significance of various themes (a tactic typical of popular approaches) or through the subjective (and often convenient) judgments of redaction criticism (as seen in attributing all references to the fear of God to a "pious redactor").
} 
select prominent motifs within the book of Qohelet, performed at an academic level, with the goal in mind of establishing a balanced, wisdom based approach to Qohelet.

The thesis of this dissertation is as follows: The key to reaching a balanced and accurate understanding of the book of Qohelet lies in discovering the inter-dependent relationships between the prominent motifs observable within the book. This involves an analysis of each prominent motif in light of its relationship with other motifs internal to the book of Qohelet. Such an approach will lead to a balanced message where all motifs are given equal consideration in assessing the overall line of argument within Qohelet. The final outcome of such an approach is a wisdom based paradigm for living "under the sun," a wise man's approach to living in a הבל world. ${ }^{105}$ Qohelet's conclusions are twofold and equally balanced. First, in light of the fact that life is fleeting, death is inevitable, and the circumstances of one's future lie outside of the realm of man's control, the wise will enjoy life as a gift from God, recognizing that joy is ultimately a responsibility placed before him. Second, in light of the fact that life is fleeting, death is inevitable, and God's enigmatic ways on earth are sure to be followed by an equitable future judgment, the wise will fear God and keep his commandments. ${ }^{106}$ Therefore, the wise man or woman will enjoy life but not enjoy sin, living each day to its fullest, but also living in

105 The idea of a "הבלל world" entails a multivalent understanding of the term as used by Qohelet in the programmatic superlative of the $1: 2 ; 12: 8$ inclusio. Such an indictment entails elements of transience, enigma, futility, and the negative evaluation of observable circumstances and events in the fallen world in which man lives.

${ }^{106}$ It is within the thesis of this dissertation that Qohelet expects some form of future judgment, although the details regarding its nature are vague at best. Furthermore, this expectation is authentic, and not the work of a "pious redactor." Most commentators do not accept a future expectation of judgment or afterlife within the theology of Qohelet, although few commentators have suggested that such a theology is implied, at least in an embryonic form. See Farmer, Who Knows What is Good?, 203-06. For a more thorough treatment within this dissertation, see pages 166-74 and 219-25. 
sobriety, knowing that for all our actions there is a coming judgment. This is the wisdom of Qohelet. 


\section{CHAPTER 2}

\section{THE DILEMMA OF HEBEL AND THE QUEST FOR YITRON IN THE BOOK OF QOHELET}

In beginning our treatment of the prominent motifs within the book of Qohelet, it is fitting that we start with an exploration into the state of being described by Qohelet through the use of the key word הבל הבל The The approach our discussion the perspective that it exists not only as a (or the) key word in the text, but also from the perspective that הבל is more than simply a descriptive term, but it is a situation, or state of being, that takes on the significance of being a key motif in Qohelet's thought. ${ }^{2}$

So far as the prominence of the term is concerned, there is no doubt that the term plays a major role developing the mood, if not the message, of the book. Nevertheless, for such a significant and prominent term, there is a general lack of consensus among scholars regarding the meaning of the term as used in Qohelet. Therefore, any exploration into the role of הבל הarvey a motif must include a survey approaches taken by scholars in seeking to define the term as well as a lexical treatment of הבל itself.

הבל is used 38 times throughout the book, with the superlative form of the word framing the book through "inclusio" at the beginning and the end of the literary quest

\footnotetext{
${ }^{1}$ In general, I will use Hebrew font when referencing this key word, although informal transliteration may be called upon in referencing conceptual ideas related to symbol and motif. Also, it should be noted that the term is frequently referenced through informal transliteration in quotations, and I will keep the informal transliteration in these references.

${ }^{2} \mathrm{H}$. Carl Shank accurately refers to הבל a a "situation" when he describes it as "the reality of the curse of God placed upon the work of man after the Fall." See H. Carl Shank, "Qohelet's World and Life View as Seen in his Recurring Phrases," WTJ 37 (1974): 67. The key word "תרון" (defined lexically as "gain" or advantage") will be examined on pages 76-81 as a "solution" to the "situation," or dilemma, of
} 
$(1: 2 ; 12: 8)$. Between the superlative phrases marking the "bookends" to Qohelet's investigation, the term is used in a variety of contexts and with some variety of literary function, at times introducing a new pericope and in other cases bringing a particular segment to conclusion. ${ }^{3}$ Despite the variety of contexts in which the term is found throughout Qohelet, modern English translations have typically been consistent in translating the term uniformly throughout the book. The KJV, NKJV, ESV and NRSV are consistent in translating הבל as "vanity" throughout the book, whereas the NIV consistently translates the term as "meaningless." The NLT also translates הבל "meaningless," but introduces some variety in translating adjectival uses of הבל as "empty" in 5:7 (Hebrew 5:6) and 6:12. The NASB typically uses "vanity," but does display semantic variety when translating in certain contexts. For instance, "emptiness" is used in 5:7 (Hebrew 5:6), "futile" in 6:12, "futility" in 2:1; 8:14 and 11:8, and "fleeting" in 9:9 and 11:10. The Jewish Tanakh typically translates הבל as "futility," but demonstrates variety in certain contexts such as $6: 12,9: 9$, and 11:10 with "fleeting," $8: 14$ with "frustration," and 11:8 with "nothingness."

The etymological traditions by which translations such as "vanity" and "meaningless" have originated become increasingly apparent when noting the way in הבל המל הבל Thich the Septuagint and the Vulgate have translated translates

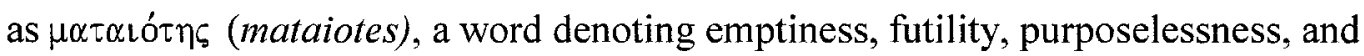

\footnotetext{
${ }^{3}$ The literary function by which Qohelet uses introductory "הבלל " clauses" and concluding judgments" in turn mirrors on a smaller scale and in a more defined fashion the introductory and concluding comprehensive הבל superlatives.
} 
transitoriness. ${ }^{4}$ Following the Septuagint, the Latin Vulgate translated הבל as "vanitas," thus paving the way for the KJV's use of the "vanity" gloss. ${ }^{5}$

It is interesting that the one popular translation which is most closely aligned with a literal translation of הבל is Eugene Peterson's paraphrase, The Message. ${ }^{6}$ The Message translates as "smoke," which is actually quite close to the literal meaning of the term, "vapour" or "breath." While BDB does allow for a figurative definition of the noun form as "vanity," this nevertheless does not negate the concrete literal meaning of "vapour" or

\footnotetext{
${ }^{4}$ Daniel C. Fredericks, Coping with Transience, 15. See also Verlyn D. Verbrugge, ed., New International Dictionary of New Testament Theology, abridged ed. (Grand Rapids: Zondervan, 2000), 358. The Septuagint translation at this point has already become quite interpretive, having chosen not to use the Greek term $\dot{\alpha} \tau \mu i \varsigma$ (atmis, "vapor" or "mist"), which if employed would have retained greater literal proximity to the concrete meaning of הבלה.

${ }^{5}$ Describing the development of the word as depicted in the Vulgate, Fredericks states, "The Vulgate, however, with vanitas ("emptiness') limited both the richness and the options that inhere in the metaphor by precluding the temporal meaning of 'transitoriness', leaving a meaning only pertaining to value. This connotation of valuelessness has taken precedence ever since, and the translations seldom convey explicitly the inherent transitoriness of hebel'; see Fredericks, Coping with Transience, 15. Fredericks makes note of this etymological influence as he is seeking to support his case for the primacy of "transience" in the meaning of הבל, but even with such intentions understood, it is noteworthy that the Vulgate has been very influential in the formulation of English translations, especially the King James Version, which has consistently translated הבל throughout Ecclesiastes as "vanity", even when the context is clearly not value based. For more on the influence of the Vulgate in English translation, see Bruce M. Metzger, The Bible in Translation (Grand Rapids: Baker Academic, 2001), 29-35 and Paul D. Wegner, The Journey from Texts to Translations (Grand Rapids: Baker Academic, 1999), 243-47. 1997).

${ }^{6}$ Eugene H. Peterson, The Message: Old Testament Wisdom Books (Colorado Springs: NavPress,

${ }^{7}$ This determination of the "literal term" is based upon the lexical definition found in F. Brown, S. Driver, and C. Briggs, The Brown-Driver-Briggs Hebrew and English Lexicon $6^{\text {th }}$ revised ed. (Peabody, Mass: Hendrickson, 2001), 210. While approximate to the literal (which is quite ironic in a paraphrase), the translation "smoke" fails to adequately communicate the meaning of הבל in Qohelet. Citing Andre Chouraqui who translates 1:2 and 12:8 as "smoke of smoke, all is smoke" (La Bible, traduite et presentee par Andre Chouraqui [Paris: Desclee de Brouwer, 1975], 113-14), Jacques Ellul writes, "I disagree with this interpretation. In the first place, as with 'vapor', I fail to see the meaning of 'smoke of smoke.' All I see in it is a silly redundancy....I cannot see that this idea has anything to do with Qohelet's content." Although there is some precedent to translate the term in a literal fashion, 1 agree that this does little to help the reader to understand the content of Qohelet's message. See Jacques Ellul, Reason for Being: $A$ Meditation on Ecclesiastes (Grand Rapids: Eerdmans, 1990), 50.
} 
"breath". Jenni and Westermann define the "basic meaning" of הבל as "wind, breath," thus falling much in line with BDB. ${ }^{9}$ The Jenni and Westermann entry continues, however, to state that the "basic meaning totally disappears in the largest category of occurrences (nom. Clauses); here hebel is simply a negative term characterizing human experiences and basic qualities." 10 Within Qohelet itself, Jenni and Westerman see concepts such as "unproductive, useless, vain, senseless, transience, incomprehension and finitude" expressed by Qohelet through the word הבל.

The New International Dictionary of Old Testament Theology and Exegesis lists the following English translations as reflective of the nominative form of הבל: wind, breath, vapor; futile, vain, empty, void, worthless, profitless; transitory, fleeting; and enigmatic. $^{12}$ The first series of terms relate to the literal meaning of the word, while the following three sets (separated by the semicolon) suggest possible figurative meanings for the word as it is employed throughout the Old Testament. Breath and vapor are by their very nature immaterial, transient, and fleeting. Johnston suggests that in certain contexts this "yields the abstract negative, viz., that which is unsubstantial (Jer 10:15; $16: 19 ; 51: 18$ ), worthless ( $\operatorname{Kgs} 17: 15 ;$ Jer $2: 5 ; 10: 3$ ), unprofitable (Prov 13:11), futile

${ }^{8}$ Ibid. The verbal root is attested Old Aramaic, Syriac, Arabic, and Late Egyptian (as a Semitic loanword). In each case the nominative form denotes wind, breath, vapor, or by metaphoric extension, vainity and emptiness. See D. C. Fredericks, "הבל," Willem A. VanGemeren, gen. ed., New International Dictionary of Old Testament Theology and Exegesis, vol. 1 (Grand Rapids: Zondervan, 1997), 1003.

${ }^{9}$ Jenni and Westermann, Theological Lexicon of the Old Testament, vol. 1 (Peabody, Mass: Hendrickson, 1997), 351.

${ }^{10}$ Ibid. Of course the concept of a "negative connotation" is highly interpretive. Furthermore, the "precise nature of the negative connotation intended results only from the context": possible connotations include "unstable" (Ps 62:10), "transitory" (Ps 144:4), "useless, vain" (Eccl 2:11), to "senseless, nonsense, bad" (Eccl 6:2).

${ }^{11}$ Ibid.

${ }^{12}$ D. C. Fredericks, “לבה," NIDOTTE, 1003-005. 
(Lam 4:17; Eccl 1:2, 14; 2:1, 14-15), transient and fleeting (Job 7:16; Prov 31:30; Eccl $11: 10) . " 13$

\section{A Survey of the Use of הבל in the Old Testament}

In an abridged survey of the various ways in which the Old Testament uses the word the breadth of the word's semantic range becomes quite obvious. For instance, the psalmist uses the word with the obvious connotation of "transience" in Ps 144:4 and Ps $39: 4[5], 5[6], 11[12]:$

Psalm 144:4 (NIV) Man is like a breath (הבל); his days are like a fleeting shadow.

Psalm 39:4-5 (NIV) "Show me, O LORD, my life's end and the number of my days; let me know how fleeting is my life. You have made my days a mere handbreadth; the span of my years is as nothing before you. Each man's life is but a breath (הבל). Selah

Psalm 39:11 (NIV) You rebuke and discipline men for their sin; you consume their wealth like a moth-- each man is but a breath (הבל). Selah

Job also regards his life as "fleeting", or as הבל, set in parallel arrangement to "not live forever":

Job 7:16 (NASB) "I waste away; I will not live forever. Leave me alone, for my days are but a breath (הבל).

The righteous describe their piety as "vain" when no immediate fruit is evident (Job 9:29; Isa 49:4), using the word הבל adjectivally:

Job 9:29 (NASB) "I am accounted wicked, Why then should I toil in vain (הבל)?

\footnotetext{
${ }^{13}$ Ibid. The Theological Dictionary of the Old Testament lists many of the same glosses, but stresses that the abstract connotation of the literal word allows for an openness to new meanings, even suggesting that the "range of meaning of hebhel is open" and that "it is especially suited therefore to be a keyword or catchword." See G. Johannes Botterweck and Helmer Ringgren, gen. ed. Theological Dictionary of the Old Testament, vol. 3 (Grand Rapids: Eerdmans, 1978), 315.
} 
Isaiah 49:4 (NASB) But I said, "I have toiled in vain (ריק), I have spent My strength for nothing (תהו) and vanity (הבל); Yet surely the justice due to Me is with the LORD, And My reward with My God."

Psalm 62:9[10], 10[11] describe "lowborn men" as, defined in this context by the parallel terms "lie" and "nothing," thus denoting emptiness and lack of substance:

Psalm 62:9-10 (NASB) Men of low degree are only vanity (הבל)and men of rank are a lie; In the balances they go up; They are together lighter than breath (הבל). Do not trust in oppression And do not vainly (הבל) hope in robbery; If riches increase, do not set your heart upon them.

Words are often described as הבל Included in this designation are texts involving Job's dialogue with his friends (in each of these, note the character of insult inherent in these descriptions, Job $21: 34 ; 27: 12 ; 35: 16)$ :

Job 21:34 (NASB) "How then will you vainly (הבל) comfort me, For your answers remain full of falsehood?"

Job 27:12 (NASB) "Behold, all of you have seen it; Why then do you act foolishly (הבל)?

Job 35:16 - 36:1 (NASB) So Job opens his mouth emptily (הבל); He multiplies words without knowledge."

The words of false prophets (Jer 23:16) denote falsity and lack of substance:

Jeremiah 23:16 Thus says the LORD of hosts, "Do not listen to the words of the prophets who are prophesying to you. They are leading you into futility (הבל);

They speak a vision of their own imagination, Not from the mouth of the LORD.

At times, הבל functions as a metaphor for "insubstantial because false," thus describing the components of false religion as "without substance" and "insubstantial." Thus, the term can be understood as a near synonym for "idol," e.g., Jer 10:8; 14:22:

Jeremiah 10:8 (NASB) But they are altogether stupid and foolish In their discipline of delusion-- their idol (הבל) is wood!

Jeremiah 14:22 (NASB) Are there any among the idols (הבל) of the nations who give rain? Or can the heavens grant showers? Is it not You, O LORD our God? Therefore we hope in You, For You are the one who has done all these things. 
In Jeremiah, the term is used almost exclusively in this sense, with הבל referring to the "totality of any false religion." (Jer 2:5; 8:19):

Jeremiah 2:5 (NASB) Thus says the LORD, "What injustice did your fathers find in Me, That they went far from Me And walked after emptiness (הכל) and became empty (לב)?

Jeremiah 8:19 (NASB) Behold, listen! The cry of the daughter of my people from a distant land: "Is the LORD not in Zion? Is her King not within her?" "Why have they provoked Me with their graven images, with foreign idols (הבל)?"

The obvious conclusion from this short survey is that the semantic range of the term in the Old Testament is quite broad. As interesting and significant as the semantic range of the term in the Old Testament may be, the real point of contention for Qohelet studies is whether or not the term takes on distinctive lexical elements as used in Qohelet.

Furthermore, Qohelet scholars debate whether or not the term should best be understood throughout the book with one distinctive definition in mind, or if the term should be allowed enough contextual flexibility to incorporate a wide range of metaphorically based meanings. $^{14}$

\section{A Survey of Contemporary Approaches to the Use of הבל in Qohelet}

A survey of contemporary approaches to the meaning of הבל in Qohelet reveals a general lack of agreement within the scholarly community. Approaches fall roughly into two major categories: 1) those who advocate a singular, primary meaning to the word

\footnotetext{
${ }^{14}$ Opinion varies broadly in the ranks of scholarship. The range includes on one end of the הבל" a spectrum scholars such as Douglas B. Miller who propose multiple qualities incorporated into a symbol," to those such as Michael Fox who argues that "the hebel leitmotif disintegrates if the word is assigned several different meaning." See Douglas B. Miller, Symbol and Rhetoric in Ecclesiastes: The Place of Hebel in Qohelet's Work, (Atlanta: Society of Biblical Literature, 2002), and Michael Fox, Qoheleth and his Contradictions, (Sheffield: Almond, 1989), 36. The question of polyvalency versus monovalency is critical to this discussion and will be taken up in detail in the following pages.
} 
and 2) those who advocate the recognition of a broad semantic range for הבל within

Qohelet. Most commentators recognize that context always takes precedence over

lexicology in defining the particular nuances of a word, however, there is a general desire among commentators to find a primary meaning for הבל in Qohelet that can then be applied to all contexts within the book of Qohelet. ${ }^{15}$ For this reason the following survey will be arranged by beginning with the advocates of monovalent glosses for הבל and then follow with an examination of the proponents of a broader, decentralized (poly, multi, or omni-valent) understanding of הבל in Qohelet.

הבל Understood Exclusively as "Fleeting," "Transitory," or "Brevity"

The major proponent of the view that primarily connotes the concept of transience is

Daniel C. Fredericks. ${ }^{16}$ It is Frederick's thesis that transience is the major thematic thread in the book. While recognizing that there are a few cases where הבל may connote futility $(5: 7 ; 6: 4,11)$, Fredericks states that these "should not invert the proportion toward a

\footnotetext{
${ }^{15}$ For the sake of fairness, most commentators who seek to find a primary definition for הב in Qohelet do recognize the difficulty of doing so when all of the contextually based usages of the word in Qohelet are examined. Nevertheless, even with this contextual flexibility recognized, the following survey will indicate a propensity towards generalization among most commentators. This is at least in part due to the occurrence of "comprehensive" הבל judgments throughout the book. Fox echoes this thought by stating, "Qohelet's statement 'all is hebel' strongly implies that there is some meaning common to the various occurrences of the term." He furthermore suggests that the comprehensive application of the term is not compatible with contextually diverse glosses. See Michael V. Fox, "The Meaning of Hebel for Qohelet," $J B L 105$ (1986): 411.

${ }^{16}$ See Fredericks, Coping with Transience. Although Fredericks is considered the "major" proponent of this view due to this monograph devoted to the thesis equating with transience, he is not the only proponent of this view. See also R. B. Y. Scott, Proverbs, Ecclesiastes: A New Translation with Introduction and Commentary (New York: Doubleday, 1965), 209; Kathleen Farmer, Who Knows What is Good?, 143, 152; and Timothy K. Beal, "C(ha)osmopolis: Qohelet's Last Words," in God in the Fray: A Tribute to Walter Brueggeman (ed. Tod Linafelt and Timothy K. Beal (Minneapolis: Augsburg Fortress, 1998), 302. Of additional interest is the work of Shannon Burkes, who through the correlation of הבל to the inevitability of death motif, has in turn defined הבל primarily through the glosses associated with transience. See Shannon Burkes, Death in Qoheleth and Egyptian Biographies of the Late Period (Atlanta: Society of Biblical Literature, 1999), 45-59.
} 
message of futility for the book as a whole." ${ }^{, 17}$ Advocating the prominence of transience in Qohelet's thought, Fredericks continues, "It is as if Qohelet assumes that we have learned that life is like a breath, brief in length; that fact we know from many poets and sages, not to speak of our own experience. But now he wants us to be aware of the fact that every experience within life is breath, everything will pass." 18

To support his thesis, Fredericks appeals to the relationship of הבל to the prominent theme of the "inevitability of death," noting that for Qohelet death is not a "penetrating threat, but a necessary consideration." in hand with the "inevitability of death" motif, thus recognizing life as truly fleeting and transient. Furthermore, Fredericks appeals to the theme of "the enjoyment of life" as supportive of the "transient" view of הבל. For Qohelet, any solution to the "dilemma of "הבל " is not found in lengthening the duration of one's life, but rather, in improving the quality of one's fleeting life. ${ }^{20}$ If the primary meaning of הבל is "futility", then the commendation of the enjoyment of life would only perpetuate that which is futile. If life is vain, then why the urgency to enjoy it now ${ }^{21}$ However, if life is transient, then the enjoyment of life should indeed be considered a "wise man's concession," an approach to life that does seek to make the most of every day that God has provided as a gift (in a

\footnotetext{
${ }^{17}$ Fredericks, Coping with Transience, 24.

${ }^{18}$ Ibid.

${ }^{19}$ Ibid., 33.

${ }^{20}$ Ibid, 41. The phrase "dilemma of הבר" is my own, and is used to depict a state or situation in which man lives. Furthermore, this "state of being" is experienced from the perspective in which man lives, that is, "under the sun." The "dilemma of "הבל" stems from the fallen condition in which man lives, and as a "situation," implies even apart from lexical/contextual study a certain degree of multivalency necessary in describing the complexities of the fallen world in which man lives and relates to God and his
} creation.

${ }^{21}$ Ibid, 69. 
fleeting life, there is no guarantee of tomorrow; indeed, each new day is a gift from God). ${ }^{22}$

A strong argument raised by Fredericks for the "brevity view" pertains to the lack of use in Qohelet of Hebrew words that do denote the more negative aspects of futility and vanity (this despite their obvious availability). Fredericks notes that words such as ("nothing, naught"), ("empty, idle, worthless"), שוא ("emptiness, vanity"), and ("empty, unreal, worthless") are found nearly 100 times outside of Ecclesiastes, yet Qohelet uses the more obscure and metaphorical term הבל throughout his work. ${ }^{23}$ The obvious point of Frederick's observation is that if Qohelet meant to emphasize life's being vain, he could have done so by using more direct and precise Hebrew vocabulary. ${ }^{24}$

Although Fredericks does appeal to the use of companion phrases to support his view of הבל, he does run into difficulty with the phrase רעות רוד (traditionally rendered "chasing the wind"). For Fredericks, the remedy to this companion (a companion phrase that seems to denote that which is futile) is to argue for the translation "desire of wind" as opposed to "shepherding" or "chasing" the wind. Furthermore, Fredericks argues for a subjective, possessive translation of the Hebrew genitive rather than the typical objective rendering. Thus, instead of "desire of wind" the phrase should be

\footnotetext{
${ }^{22}$ The idea of the "wise man's concession" is this writer's extrapolation of the enjoyment of life framed within the "transient" view, and does not belong to Fredericks.

${ }^{23}$ Fredericks, Coping with Transience, 28.

${ }^{24}$ In opposition to Fredericks, I will later propose the view that Qohelet intentionally used a word that indeed is metaphorical for the purpose of denoting many concepts in one word (including nuances of transience and futility), a feat not possible if Qohelet had employed the less figurative terminology referenced by Fredericks.
} 
translated "the wind's desire." 25 As explained by Fredericks, the "phrase would then be metaphorical just as הבל is, connoting the brevity of life and its experiences which are like the wind's desire that changes from north to south, east to west, downward, upward, around and even virtually still., ${ }^{26}$ Although Frederick's does not explicate this metaphor further, the assumed idea is that the wind's direction is transient, never remaining the same for any lengthy period of time. Such a point of comparison for the metaphor is obviously a stretch even if one were to agree with Fredericks regarding the syntax of the phrase, but to argue for a primary, and especially an exclusive emphasis on transience, one must do something like what Fredericks has done with the רעות רוד phrase.

\section{הבל Understood Exclusively as "Meaningless"}

Besides the obvious exegetical opinion of the NIV translating committee having translated הבל exclusively as "meaningless" throughout Qohelet, one major commentator advocating this approach is Tremper Longman III. ${ }^{27}$ Longman appeals to the linkage in the Old Testament between הבל and idols (at times, and especially in Jeremiah, the two are practically synonymous) in support of his position. Regarding this assessment of passages where הבל is used to refer to idols, Longman states, "It is absolutely certain that these passages are attributing uselessness or meaninglessness to the idols, not transitoriness. Indeed, if they were transitory, they would eventually pass away and not be the cause of such major concern." 28 Of course, one could say that a "meaningless" or

\footnotetext{
${ }^{25}$ See Fredericks, Coping with Transience, 29-30 for a complete explanation of Frederick's exegetical argument.

${ }^{26}$ Fredericks, Coping with Transience, 30.

${ }^{27}$ Longman, Ecclesiastes.

${ }^{28}$ Ibid, 63.
} 
"useless" idol is also of no concern; Longman does not appear to recognize that idols might be understood as "meaningless" precisely because they are passing away. ${ }^{29}$

Longman also appeals to the Septuagint and Vulgate translations to support his position, noting that these early translations (which in his view must carry substantial exegetical clout) must have understood the word to denote "meaninglessness" rather than "brevity." ${ }^{30}$ In the end, however, the most significant influence supporting the use of "meaningless" as a gloss is Longman's own admittedly negative approach to the whole message of the book. ${ }^{31}$

הבל Understood as Denoting Futility Based on the Recognition of Transience Embracing the two major nuances of "futility" and "brevity," some commentators recognize in הבל a dependent relationship between these two major nuances. ${ }^{32}$ Iain Provan goes to great lengths to state his case that הבל is certainly not referring to life's being meaningless, but rather, that the primary focus in Qohelet is on the "ephemerality of reality" as depicted in the word הבל Pבל Pב Provan argues that in best understood in the refrains of $1: 2$ and 12:8 to reflect this idea of ephemerality (translated as "fleeting" or

${ }^{29}$ One may also argue that the word הבל adequately describes an idol precisely because the idol is both "meaningless" and "passing away." It is literally as "breath," insubstantial when compared to Yahweh.

${ }^{30}$ Ibid, 64 . The Greek mataiotes and the Latin vanitas both clearly emphasize a lack of value, understood by English terms such as "meaningless" and "vanity." See Verbrugge, New International Dictionary of New Testament Theology, 358.

${ }^{31}$ Longman does recognize that he is involved in an aspect of the "hermeneutical spiral" which is determining the meaning of a particular word based upon the perceived meaning of the book as a whole. The irony in this hermeneutic is that the only way to understand the meaning of the book as a whole is to first properly understand the meaning of the particular words that come together to form that whole. See Longman, Ecclesiastes, 64.

${ }^{32}$ For four major proponents of this view, see Kruger, Qoheleth; Iain Provan, Ecclesiastes/Song of Songs; James L. Crenshaw, Ecclesiastes; and H. C. Leupold, Exposition of Ecclesiastes (Grand Rapids: Baker Book House, 1952). 
"brevity"), thus encompassing the "foundational truth on which Qohelet premises all his words, that life is 'like a breath"." 33 Provan, however, does not argue for an exclusive understanding of הבל as such, but recognizes contextual strains where הבל does reflect the idea of "futility." When referencing the nature of life, Qohelet describes life as "fleeting." However, when referencing the tasks in which man seeks to find יתרון ("gain" or "advantage," based upon 1:3), Qohelet understands these tasks to be "futile." Thus, any הבל pursuit or task seeking to find הבל a ("fleeting") world (or life) is ultimately ("futile"). ${ }^{34}$

Thomas Kruger takes a similar approach in understanding a "comprehensive" view of הבל that focuses on the transitory nature of life ("all is הבל"), and a limited view of הבל ("דבל ("this ) that understands the technical diversity of the term as applied to particular contexts. ${ }^{35}$ Like Provan, Kruger understands that there is an element in which "all convictions and wishes prove to be futile when they do not do adequate justice to the fleeting nature of human life." 36 In this regard, Kruger too sees that the various means by which one may pursue יתרון are ultimately futile in seeking to solve the "dilemma of (life lived in conscious awareness of its own transient nature). ${ }^{37}$

\footnotetext{
${ }^{33}$ Provan, Ecclesiastes/Song of Songs, 52.

${ }^{34}$ Ibid, 57.

${ }^{35}$ It should be noted that Kruger and Provan both recognize that הבל, when employed in "limited" contexts, can convey nuanced definitions besides "brevity" and "futility". For instance, Provan refers to the "elusive" nature of reality in many הבל statements. See Provan, Ecclesiastes/Song of Songs, 52.

${ }^{36}$ Kruger, Qoheleth, 3. of this work.

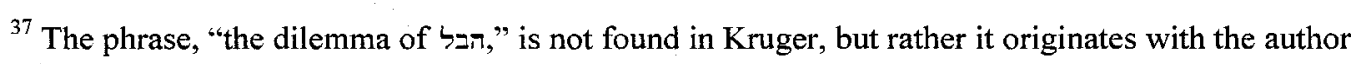


It is interesting that Crenshaw takes an approach almost opposite to that of הבל Kruger, reversing Kruger's glosses attendant to the comprehensive and limited judgments. Crenshaw agrees that הבל essentially demonstrates two nuances: the "temporal ('ephemerality') and existential ('futility' or 'absurdity')." ${ }^{38}$ However, he applies the nuance of futility to the comprehensive inclusio, thus implying that while "several uses in the book virtually demand the first meaning, that of fleeting appearance and emphemerality," the normal sense of the word is a judgment of futility rather than a statement of fact regarding emphemerality. ${ }^{39}$

\section{הבל Understood as "Enigmatic"}

הבל Besides the "vanity" and the "brevity" families, another popular approach is to regard as "enigmatic," "incomprehensible," or "absurd." ${ }^{40}$ A proponent of this family of terms, Graham Ogden, defines variably as "enigma," "irony," or "the anomalies of human experience. ${ }^{41}$ Ogden understands that more specific terms are appropriate for the various contexts within Qohelet where הבל statements are found, but he consistently appeals to

\footnotetext{
${ }^{38}$ Crenshaw, Ecclesiastes, 57.

${ }^{39}$ Ibid, 58. For another popular commentator espousing the prominence of "futility" in defining Qohelet's comprehensive use of הבל, see Derek Kidner, The Message of Ecclesiastes: A Time to Mourn and a Time to Dance (Leicester: Intervarsity, 1976), 22.

${ }^{40}$ Although introducing these three terms as a "family," all three terms will be first treated as independent glosses. It is also noteworthy that the gloss "meaningless," while perhaps best categorized under the broader heading of "vanity," can be understood in relationship to that which is "absurd." Michael Fox clarifies this relationship by saying, "Similarly, while hebel is a near-synonym of 'meaningless,' the terms differ insofar as 'absurd' is not merely the absence of meaning, but an active violation of meaningfulness." See Michael Fox, Qohelet and his Contradictions (Sheffield: Sheffield Academic Press, 1989), 36.

${ }^{41}$ See Graham Ogden, Qoheleth (Sheffield, England: JSOT Press, 1987), 19-22. This opinion is further treated by Ogden in the article, "Vanity", it Certainly is Not," BT 38 (1987): 301-07.
} 
terms within this "enigma" family, at times stretching his exegesis to avoid using the terms contained within the "brevity" or "vanity" families. ${ }^{42}$

Ogden's strongest arguments may come through his exegesis of certain "painful scenarios to which the hevel phrase is added as a response" $(3: 16-19 ; 6: 1-2 ; 4: 7-8 ;$ and $8: 14) .{ }^{43}$ For example, in $8: 14$, Qohelet observes that good things happen to bad people, and bad things happen to good people. In this situation, Qohelet twice describes the situation as הבל. This situation is certainly not one in which brevity applies, nor does life become without meaning in light of this observation. Rather, "in describing this scenario as hebel, Qoheleth's meaning is that life is enigmatic, and the sign of wisdom is that one can accept that." 44

Ogden also finds strong appeal for his position by noting the complimentary phrases and parallels to the הבל statements. While most commentators recognize the act of "shepherding the wind" to be indicative of futility, Ogden sees a kind of ironic humor in the phrase; a delightfully idiomatic phrase for attempting the impossible. ${ }^{45}$ The "sore affliction" of 6:1 emphasizes the "anomaly of the situation described," and the "unhappy business" of 4:8 points to "situations in life which defy our human comprehension." 46

\footnotetext{
${ }^{42}$ This strained exegesis is evident in Ogden's article "Qoheleth XI 7-XII 8: Qoheleth's Summons to Enjoyment and Reflection," Vetus Testamentum XXXIV, 1 (1984): 32. Here Ogden understands Qoheleth's "raflections upon youth as referring to something that even for the sage is enigmatic and incomprehensible. One could argue that Qoheleth saw youth as enigmatic when set in conjunction with the aging process, but to understand youth as "fleeting" is a far less strained definition within this context.

${ }^{43}$ Ogden, Qoheleth, 18-20.

${ }^{44} \mathrm{Ibid}, 20$. It is worth noting that Fox opposes such a conclusion on the grounds of inequity: "it is not the mysteriousness of the situation that pains Qohelet, but its inequity." See Michael Fox, "The Meaning of Hebel for Qohelet," JBL 105 (1986): 413.

${ }^{45}$ Ibid.

${ }^{46} \mathrm{Ibid}, 21$.
} 
While Ogden may be correct to view enigmatic aspects within each of these phrases, his intent to view these as only referring to that which is enigmatic may be leaving out other aspects of meaning that are intended by Qohelet as he reflects on these various observations.

\section{תבל Understood as "Incomprehensible"}

Although not advocating an exclusive view of "incomprehensible" as being the only definition of הבל in Qohelet, ${ }^{47}$ Choon-Leong Seow does see this definition as primary. Seow understands הבל to represent incomprehension through life's many apparent contradictions, the perplexities of which are elusive, failing to be grasped by human wisdom (thus the parallel statement, "chasing after the wind"). ${ }^{48}$ Even so, Seow does allow for other nuances to influence his understanding of so that terms such as "superficial, ephemeral, insubstantial, incomprehensible, enigmatic, inconsistent, and contradictory" at times may be applied to that which is הבל ה ${ }^{49}$ Seow also alludes to the aspect of transience when describing הבל as "something that one encounters or experiences for only a moment, but it cannot be grasped-neither physically nor intellectually." ${ }^{50}$ However, in Seow's approach, these concessions to "brevity" are only peripheral, whereas the primary observations deemed "הבל" are used to describe the

${ }^{47}$ Seow admits that "In Ecclesiastes itself, the meaning of hebel is difficult to determine" and "No single definition ... works in every case." Furthermore, summarizing Qohelet's observations throughout the book, Seow states, "In sum, Qohelet always begins his reflection with humanity and the human condition. He concludes at every turn that mortals are not in control of the things that happen in the world. They are not in control of their destiny. This is why Qohelet says that everything is hebel. He does not mean that everything is meaningless or insignificant, but that everything is beyond human apprehension and comprehension." See Seow, Ecclesiastes, 102.

${ }^{48}$ Seow, Ecclesiastes, $42-43$.

${ }^{49}$ Ibid, 47.

${ }^{50}$ Ibid. 
actions of man and the anomalies of life that lead the sage to conclude that all is "incomprehensible."

\section{הבל Understood as "Absurdity"}

Michael V. Fox has proposed an understanding of הבל that forges new semantic territory, defining הבל as "absurd." While admitting that this definition "finds no precise parallel elsewhere in the Old Testament," Fox argues that "Qohelet has new things to say and must push the limits of the available vocabulary." "Fox is careful to distinguish "absurd" from terms such as "mysterious," "incomprehensible," and "ironic." For example, Fox states, "Incomprehensible indicates that the meaning of a phenomenon is opaque to human intellect but allows for, and may even suggest, that it is actually meaningful and significant. To call something 'absurd,' on the other hand, is to claim some knowledge about its quality: the fact that it is contrary to reason-perhaps only to human reason, but that is the only reason we have access to, unless one appeals to revelation." ${ }^{., 2}$ For Fox, the absurd is "a disjunction between two phenomena that are thought to be linked by a bond of harmony or causality, or that should be linked. Such bonds are the sine qua non of rationality, and all deduction and explanation presupposes them. Thus the absurd is irrational, an affront to reason-the human faculty that seeks and discovers order in the

${ }^{51}$ Fox, A Time To Tear Down, 29. Other works by Fox proposing the theory that הבל Should best be understood as "absurd" include "The Meaning of Hebel for Qohelet," JBL 105 (1986): 409-27 and Qohelet and His Contradictions, JSOTup 71 (Sheffield, England: Almond, 1989). Other authors espousing the view that Qohelet's use of הבל is best understood through the term "absurd" include E.S. Christianson, A Time to Tell: Narrative Strategies in Ecclesiastes, JSOT 280 (Sheffield, England: Sheffield Academic Press, 1998), 87 and Elsa Tamez, When the Horizons Close: Rereading Ecclesiastes (Maryknoll, NY: Orbis Books, 2000), 34.

\footnotetext{
${ }^{52}$ Fox, A Time to Tear Down, 34.
} 
world about us." ${ }^{, 53}$ The thrust of Fox's approach is to understand Qohelet's quest as one which seeks to find resolution through the faculties of human reason, not through divine knowledge. Because this is never achieved by Qohelet, his judgments over various types of phenomena are to regard them as "absurd." This becomes Qohelet's "thematic declaration," the "single dominant quality in the world," and thus in Fox's estimation, in almost all cases, הבל means "absurd."

\section{Understood as "Unsatisfactory," "Frustrating," or "Foulness"}

R. N. Whybray understands הבל in most contexts to allude to "something which was fundamentally unsatisfactory and was the cause of a deep sense of frustration.".55 Likewise, Fox and other proponents of the "absurd" gloss understand absurdity to convey a negative evaluative element, and thus understand the הבל judgments as declarative opinions of what Qohelet deems to be a great inequity in the world. ${ }^{56}$ Others have

\footnotetext{
${ }^{53}$ Ibid, 31 . It should be noted that Fox takes an approach to Ecclesiastes that more closely aligns Qohelet's message with that of extra-biblical philosophical traditions rather than the genre of Hebrew wisdom literature. This criticism is explicated by John E. McKenna, "The Concept of Hebel in the Book of Ecclesiastes," SJT 45 (1992): 20-22.

${ }^{54}$ Fox, A Time to Tear Down, 35. Fox does admit that in reference to "living beings," the judgments may better be understood to emphasize ephemerality rather than absurdity (Fox, $A$ Time to Tear Down, 39). The very fact that Fox admits to cases in which הבל is better understood to convey ideas other than "absurdity" would seem to serve a death blow to his thesis which rests primarily upon proving the monovalency of the definition of "absurdity" in Qohelet's use of the term הבל. However, Fox maintains that "the connotation of absurdity, established in the great majority of occurances, carries over even to cases where the primary denotation of the term is 'ephemeral' (Fox, 'The Meaning of Hebel,' 421)."

${ }^{55}$ Whybray, Ecclesiastes, 64. Whybray understands the word $3=\pi$ to be set in contrast to the "enjoy life" statements running throughout the book $(2: 24 ; 3: 12-13,22 ; 5: 18 ; 8: 15 ; 9: 7-9 ; 11: 9-10)$, yet fails to fully explain the relationship between the two themes. Do they reveal the complexity of Qohelet's thought, or inconsistencies within his thought? Whybray does excellent work with the theme of the enjoyment of life in Qohelet, but never explicates the metaphorical use of הבל in a satisfactory manner.

${ }^{56}$ Although Fox does not designate a new gloss for the frequent declarations of judgment in which Qohelet describes and qualifies an observation with negative modifiers such as evil (ע-), vexation (סע), and sickness (חל), he nevertheless understands the "absurd" to also connote an element of genuine disgust. Thus, to call something an "evil sickness" (6:2) is to also call something which in Fox's estimation still entails the "absurd."
} 
recognized an element of disgust in some הבל judgments that remind to modern reader of vulgar language meant to convey frustration and disgust in a broadly applicable fashion. ${ }^{57}$ Indicating perhaps that this aspect of the הבל metaphor is underexplored, Douglas Miller describes this sense of "foulness" as having "not been considered previously."

However, upon exploring this sense of הבל, Miller describes the "foulness" sense as the "capstone of the present thesis," presumably inferring that the negative conclusions function as a catch all to that which Qohelet describes as "הבל."59

Not only does the suggestive nature of context indicate a negative evaluative

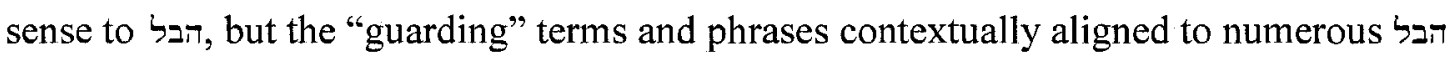
judgments also describe that which is an "affront to Qohelet's sense of justice." ${ }^{60}$ Perhaps the most important guarding term for the "foulness" sense is ("evil" or "adversity"),

\footnotetext{
${ }^{57}$ See for example Frank Crusemann and his use of the explicative as a gloss for הבל. Likewise, Elsa Tamez writes, "In everyday life, there are more trivial or less elegant words, such as 'garbage' and ' $s$ * $\$$,' that better express the malaise produced by a situation of impotence before a crushing reality. I do not know of any language that lacks this last word to express the frustration that comes from the pit of the stomach." See Frank Crusemann, "The Unchangeable World: The Crisis of Wisdom in Koheleth," The God of the Lowly: Socio-Historical Interpretations of the Bible, edited by W. Schottroff and W. Stegemann, translated by M. J. O'Connell, (Maryknoll: Orbis, 1984), 57 and Elsa Tamez, "Ecclesiastes: A Reading from the Periphery," Interpretation, 55 (2001): 251.

${ }^{58}$ Miller describes "foulness" as "an evaluative term for things in his experience which he finds to be fundamentally foul." The metaphor thus functions with proximity to its literal referent, wherein the "vapor" has become "bad air," something "repulsive and even life-threatening." See Douglas B. Miller, Symbol and Rhetoric in Ecclesiastes: The Place of Hebel in Qohelet's Work (Atlanta: Society of Biblical Literature, 2002), 95.

${ }^{59}$ Ibid. Miller's thesis states that "הבל" functions as a symbol that conveys multiple ideas concurrently but to varying degrees depending upon context. Thus, in the inclusio comprehensive statements of $1: 2$ and 12:8, the term הבל is meant to convey multiple nuances of the term (distinguished throughout the text) all at once and in suggestion of the complexities of describing the state of the fallen world.

${ }^{60}$ Ibid. It is worth noting that Miller's understanding of the "foulness" gloss is thus closely defined in the same manner as Fox's definition of the "absurd", namely, that which "is an affront to human reason (Fox, "The Meaning of Hebel, 409)." The difference is that the term "foulness" is more of an evaluation, while the "absurd" is merely a statement of fact. However, as suggested earlier, Fox does recognize the negative sense of injustice in certain הatements (such as in 8:12-14).
} 
described by Miller as "a term of negative evaluation concerning matters which are unacceptable and/or harmful, either from a divine or a human perspective." ${ }^{.61}$ Other guarding phrases and terms include the synonyms כלעם ("vexation") and ("sickness"), . often used in conjunction with nouns and adjectives to describe life in a thoroughly frustrated manner ("great evil," 2:21; "evil business," 4:8; "evil sickness," 6:2). Thus, for Miller, there is no escaping that Qohelet's use of at least in certain contexts or as communicated as a particular aspect of the whole, was meant to convey a negative assessment of things which were found abhorrent and unacceptable. ${ }^{62}$

הבל Other Miscellaneous Definitions for

Although the major approaches to have been surveyed at this point, it is worth noting a few related approaches from other commentators. Taking an approach similar to "meaningless" or "vanity," Milton P. Horne understands the word to best be defined as "total untrustworthiness. ${ }^{.63}$ His affinity towards this definition is made clear as he argues for the use of הבל in Proverbs 31:30 to be understood in the fashion of deceit-"even youth and beauty are deceitful. ${ }^{, 64}$ Essential to this understanding of הבל in Qohelet,

\footnotetext{
${ }^{61}$ Ibid, 96.

${ }^{62}$ It must be emphasized once again that Miller is expressly not taking a uniform approach to defining through the gloss of "foulness," "disgusting," abhorrent," or any other English gloss that may convey disgust and frustration. He is however bringing to bear one of the more important aspects of the metaphor that is often ignored in other glossary approaches. Thus, while Qohelet may say that all is will not say that all is רע. Nevertheless, "the scope of the term רע is subsumed within the 'all' that is hebel." In Miller's approach, the various aspects that entail "that which is הבל " may or may not be utilized in any given inference, judgment, report or injunction, but every aspect that may be communicated through the הבל הבל הבל symbol. See Miller, Symbol and Rhetoric, 49, 97.

${ }^{63}$ Milton P. Horne, Proverbs -Ecclesiastes, Smyth and Helwys Bible Commentary (Macon, GA: Smyth and Helwys, 2003).

${ }^{64}$ Ibid., 384.
} 
Horne understands the key "חיתרין " question in 1:3 to be rhetorical. implies that there is no profit to any activity. Based upon this understanding of $1: 3$, if there is no profit in any activity, then all indeed is vain, or in his estimation, "totally untrustworthy."

Walter C. Kaiser, Jr. and David Moore take similar approaches, finding a primary meaning to הבל well represented by the "vanity" gloss, but nevertheless encouraging the recognition of nuances determined by context. ${ }^{66}$ Agustinus Gianto falls into the "vanity camp," defining דבל as "futility." Finally, Charles F. Whitley, while not arguing his case as aggressively as Fredericks, advocates a view that should be categorized in the "transience camp," defining הבל as a "bubble," that which is "insubstantial and evanescent." 68

Uבל Understood in a Unique Sense not Translatable into Any Single English Term John E. McKenna argues "for a grasp of the concept of hebel in the Book of Ecclesiastes as a category of thought that permeates the meaning of the whole as well as the particular contexts explored by Qohelet." 69 This "concept," however, is not easily defined by any single English word. McKenna defines the concept as "the contingent rationality of the created reality of the world developed out of the belief that God created out of nothing

${ }^{65}$ Ibid., 383.

${ }^{66}$ David George Moore and Daniel L. Akin, Ecclesiastes, Song of Songs, Holman Old Testament Commentary (Nashville: Broadman and Holman, 2003), and Walter C. Kaiser, Jr. Ecclesiastes: Total Life (Chicago: Moody Press, 1979).

${ }^{67}$ Agustinus Gianto, “The Theme of Enjoyment in Qohelet," Biblica 73 (1992): 528-33.

${ }^{68}$ Charles F. Whitley, Koheleth (New York: De Gruyter, 1979). Similar to this is the popular level work of Warren Wiersbe who defines הבל הב הarren Wiersbe, Be Satisfied, (Colorado Springs: Chariot Victor, 1990), 19.

${ }^{69}$ John E. McKenna, "The Concept of Hebel in the Book of Ecclesiastes," SJT 45 (1992): 19-28. 
and by his Word all that has been made to be outside of himself." ${ }^{70}$ The thrust of Qohelet's thought is to explicate the distinctions between God and man, the created reality and its source. The term הבל , while not lexically divorced from the various nuances demanded by each specific context, must nevertheless be understood as a whole to point towards this distinction between that which is created and that which is not. ${ }^{71}$ The point of absurdity lies in the fact that man cannot understand through human rationality the divine realm. It is only by revelation that man can begin to understand the nature of the divine. In McKenna's understanding of Qohelet, the Word of God provides the solution to man's inability to comprehend the divine. McKenna points to this solution by stating, "The Word of God is free to create and sustain relational correspondence between the divine uncreated reality of the being of God and the created reality of all things that have been made to be outside of God." ${ }^{, 72}$

While not exhaustive, the above survey is indicative of the broad semantic range pertaining to הבל and the lack of scholarly consensus regarding its meaning in Qohelet. A more exhaustive survey would also indicate how influential one's overall approach to the book is upon determining the primary meaning (if there even is a primary meaning) of in Qohelet. From this quagmire of scholarly opinion, can any sense be made of the

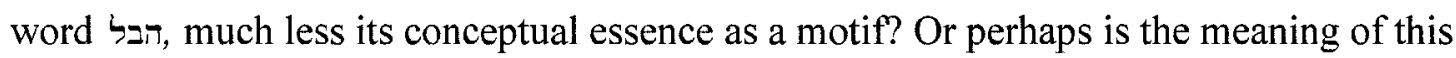
term as unobtainable as "grasping for the wind"? To this question we now turn.

\footnotetext{
${ }^{70}$ Ibid, 22.

${ }^{71}$ Ibid, 23-24.

${ }^{72}$ Ibid, 25.
} 


\section{The Flexible Nature of Metaphor as Depicted in}

The literary vehicle through which connotative flexiblity is best conveyed is figurative language, or metaphor. ${ }^{73}$ Metaphor takes a concrete image, and through a point of comparison, applies conceptual meaning to a referent. There is a clear consensus that the Hebrew word הבל literally means "vapor" or "breath." There is equally clear consensus that the word ased in Qohelet is not to be understood in a literal fashion, but rather, as a metaphor. However, as indicated by the preceding survey of commentator's approaches to there is little consensus in determining exactly what the point of comparison might be for Qohelet. Breath and vapor are indeed transient, breath and vapor can depict futility, and there is a certain sense in which breath and vapor are incomprehensible, intangible, enigmatic and absurd. ${ }^{74}$

In one context or another, any number of the glosses observed in the preceding survey may be the best definition for הבל in the particular context in which it is found, and in many cases, two or more nuances within the semantic range of Qohelet's use of

\footnotetext{
${ }^{73}$ For a detailed investigation into the use of metaphor in Qohelet, as well as the hermeneutics of and the flexibility inherent within metaphor, see Miller, Symbol and Rhetoric, 27-45. On metaphor and rhetorical criticism see Philip Wheelwright, Metaphor and Reality (Bloomington: Indiana University Press, 1962); John R. Searle, "Metaphor," in Metaphor and Thought, $2^{\text {nd }}$ ed. (Cambridge: Cambridge University Press, 1993); and Janet Martin Soskice, Metaphor and Religious Language (Oxford: Clarendon, 1985). For more on the hermeneutics of metaphor, especially in prophetic literature, see D. Brent Sandy, Plowshares and Pruning Hooks (Downers Grove: Intervarsity, 2002), 58-74.

${ }^{74}$ One must also contend with the fact that Qohelet's use of the metaphor may lack a direct point of comparison as is often the case in the development of "stock" metaphors and "dead" metaphors. Assuming the possibility that Qohelet's use of הבל incorporates the kind of familiarity germane to "stock metaphor", the range of glossary options becomes broader than that which is limited by direct comparison. It may be then that the glosses communicating disgust and frustration do not need a point of direct comparison. It is also noteworthy that precedent is set within the Old Testament for the use of as a stock metaphor in the examples where הבל is used to describe false idols and deities (1 Kgs 16:13, 26; Jer $2: 5 ; 8: 19 ; 14: 22)$. See Miller, Symbol and Rhetoric, 41,90 . On the use of stock metaphor in the Old Testament, see G. B. Caird, The Language and Imagery of the Bible (Philadelphia: Westminster, 1980), 152-58.
} 
may be intended to varying degrees within a single context! ${ }^{75}$ The use of metaphor by Qohelet permits him the flexibility to draw particularly nuanced connotations from the term and then apply them in a variety of ways to a variety of contexts. ${ }^{76}$ Qohelet could have used non-metaphorical words to describe the various scenarios, observations and entities which he judges to be הבל, but in doing so he would have limited himself to one particular meaning for each הבל judgment. However, while this may have been appropriate for particular contexts within Qohelet, it would not have conveyed the breadth of meaning reflected by the whole of the book. ${ }^{77}$

\section{as Symbol in Qohelet}

The genius of Qohelet's use of the הבל metaphor is not simply its ability to convey multivalent referents through the use of a single term, but its ability to move even beyond multivalency to omnivalency, wherein Qohelet is able to communicate the message that all human experience, as affected by the fall, can in some sense be described as הבל or as

${ }^{75}$ The view that there is an intended "flexibility of connotation" employed by Qohelet in the various contexts in which the word is found is advocated by H. Carl Shank, "Qoheleth's World and Life View as Seen in his Recurring Phrases," WTJ 37 (1974): 65-67. Shank's view is not that Qohelet intends to convey a multiplicity of meaning for the whole when using הבל in every context, but rather, that the word can take on various nuances that are drawn out of a primary meaning determined by context.

${ }^{76}$ It should be noted at this point that a distinction exists between approaches that accept a multiple number of possible glosses for הבל depending upon the context in which the word is found, and those approaches which allow for multiple meanings for הבל even in a single context. Furthermore, there lies a distinction between approaches which allow for multiple meanings as seen through the eyes of the reader, and those approaches which allow for multiple meanings as intended on the part of the author.

${ }^{77}$ When Qohelet references "all" as, he does so intentionally embracing the multitude of nuanced definitions in these comprehensive judgments. Therefore, the introduction and conclusion to the book, where the comprehensive "הבל judgments" form an inclusio to frame the book $(1: 2 ; 12: 8)$, reflect Qohelet's thought in such a way that no single literal term ever could, whether it be in Hebrew or in English. 
touched by הבל metaphor, in building the argument that becomes the הבל motif, has taken on the role of a "tensive symbol," "an image which holds together a set of meanings, or 'referents,' that can neither be exhausted nor adequately expressed by any single meaning." 79 Thus, while most texts will employ the symbol in such a fashion as to depict only a single metaphorical referent, other texts will intentionally employ various referents within the הבל symbol to convey multivalent nuances or meanings (although to differing degrees of emphasis). In most cases, the "guarding" terms and phrases typical to Qohelet's vocabulary, along with context, will function as a means to distinguish what referent or meaning is intended from the symbol to the particular context at hand. Only in the rare occurrences where the superlative חבל judgments are employed (namely, the inclusio; 1:2 and 12:8) can it be said that Qohelet is using the הבל symbol in its omnivalent sense (using הכל with reference to all of its meanings). ${ }^{80}$ It should however be remembered that even in

\footnotetext{
${ }^{78}$ Many of the same factors described by Qohelet as הבל are alluded to as consequences of the fall. The universal nature of $\sin (7: 20,29)$; the consequences of toil $(2: 11-23)$ and death $(3: 19-20 ; 9: 2-6 ; 12: 1$ 7); and the imposition of limitation upon mankind $(3: 10-14 ; 8: 16)$ all have their foundation in the Genesis account of the fall. On sin and death, see Gen 2:17;3:3, 17-19; on toil, see Gen 3:6, 17b-18; and on the implied imposition of limitation, see Gen 3:22-24. Furthermore, the outworking of sin and death finds its first example in Gen 4:1-17. It is hardly coincidental that the name of death's first victim was Abel (Hebrew הבל).

${ }^{79} \mathrm{I}$ am indebted to the work of Douglas Miller in making concrete my own thesis which had previously been only a loose collection of thoughts regarding Qohelet's use of הבל On the definition of "tensive symbol", see Wheelwright, Metaphor and Reality, 92-110 and Miller, Symbol and Rhetoric, 15, 44-46. Miller distinguishes between metaphor and symbol by stating, "Whereas a metaphor has a single valency ( $R$ value), a tensive symbol is multivalent; it embraces several meanings at the same time (Miller, Symbol and Rhetoric, 44)."

${ }^{80}$ Miller, Symbol and Rhetoric, 15.
} 
monovalent and multivalent contexts, the omnivalent image of Qohelet's הבל symbol is never far from Qohelet's mind. ${ }^{81}$

Within the הבל symbol, there exists four broad "families" of reference communicated through the use of the הבל metaphor: 1) the transience family, represented by terms such as "fleeting," "brevity," "transitory," and "ephemeral," 2) the vanity family, represented by terms such as "vanity," "insubstantiality," "futility," and "emptiness," 3) the irony family, represented by terms such as "enigmatic," "absurd," "ironic," and "incomprehensible," and finally, 4) the frustration family, represented by terms such as "foulness," "disgusting," frustration," and any number of negative evaluative expletives. ${ }^{82}$ A proper understanding of הבל will not seek to draw distinct lines of separation between these various nuances; while in certain contexts one nuance may rise to a place of prominence, the others are not too far from the scope of intention. The

\footnotetext{
${ }^{81}$ I am dependent upon Miller for his use and determination of the terms valency, multivalency, and omnivalency. In my own assessment of Miller, and in my own use of terms in this dissertation, valency refers to "meaning," and therefore multivalency refers to multiple meanings (but limited by the range of options within the הכל symbol). I use the term "monovalency" (my own term) to refer to a context in which only a single meaning is intended, and omnivalency (Miller's term, but my own definition) to refer to the totality of meaning inherent to the symbol. Thus, in my estimation, omnivalency as used by Qohelet in the הבל symbol does not permit "all meanings," but does incorporate "all meanings" within the semantic domain of the הבל symbol (which is limited by Qohelet's own very intentional use of the term). These distinctions are important as those who argue for a single meaning to Qohelet's use of הבל do so under the impression that omnivalency unnecessarily muddies the waters and opens the doors to unimpeded subjectivity, which is not the case. Omnivalency simply suggests that Qohelet has such a complex assortment of concepts in mind in communicating the הבל motif that it cannot possibly be conveyed through any one word or phrase. Note that this is contra Fox, who states that "Qohelet's statement 'all is hebel" strongly implies that there is some meaning common to the various occurrences of the term." Fox continues by stating that "we cannot say that the meaning of hebel is a bundle of all these qualities denoted by these renderings. Hebel does not include all of these senses in every application." See Fox, "The Meaning of Hebel," 411.

${ }^{82}$ Although it is difficult to "curse" in a biblical studies dissertation, it is insightful to think of how certain English language curse words have taken on the traits of a "symbol," and are thus used in contexts and in manners quite foreign to the original point of reference. This is especially true in reference to contexts in which an evaluation of disgust, disappointment, or anger is communicated. The "somewhat shocking, yet not entirely inadequate" rendering of " $s * \$ \#$ "for הבל is conceded by Tomas Frydrych, although he opts for the more socially acceptable "absurd." See Tomas Frydrych, Living Under the Sun (Leiden: Brill, 2002), 46.
} 
comprehensive wholeness of Qohelet's intention reflected in the key word הבל therefore

rejects simple translation; perhaps the most accurate rendering is to simply transliterate

and understand his reflections as "hevel." 83

Qohelet's use of the הבל symbol is purposefully ambiguous, ${ }^{84}$ yet strikingly

calculated. His intentions are descriptive as well as evaluative, employing the הבל symbol

"both to describe certain important realities and to pronounce judgment upon matters he

finds revolting." ${ }^{85}$ Just as the various families of meaning play off of one another within

the symbol, developing a semantic interdependency, so too there are often evaluative

implications to descriptive הבל statements, so that in describing that which is transient or

enigmatic, he also is through implication making a judgment as to the absurdity or

${ }^{83}$ Transliteration of course is not practical, and may be counterproductive in monovalent contexts. Additionally, the concept of הבל should always be understood with the sense that the "inherent reality that all things created and existing outside of God are הבל." This background carries significant influence in properly understanding the whole nature of the word in Qohelet's thought. See McKenna, "The Concept of Hebel," 21-25.

\footnotetext{
${ }^{84}$ Some have suggested that in light of the fact that such diversity exists in scholarly opinion as to the definition of Qohelet's use of הבל , that this implies intentional ambiguity on the part of the author. Proponents of this view include Doug Ingram, Ambiguity in Ecclesiastes (New York: T\&T Clark, 2006); Gary D. Salyer, Vain Rhetoric: Private Insight and Public Debate in Ecclesiastes, JSOTup 327 (Sheffield: Sheffield Academic Press, 2001); and Mary E. Mills, Reading Ecclesiastes: A Literary and Cultural Exegesis (Aldershot: Ashgate, 2003). Ingram describes the ambiguity inherent within the term הבל as "a deliberate strategy that contributes to the overall intentional ambiguity of the book (Ingram, Ambiguity, 129)." While I see ambiguity as an aspect of legitimate rhetorical strategy represented and reflected in the use of metaphor and symbol, I reject proposals that call for a reader response hermeneutic in reading Qohelet, at least as long as reader response is divorced from the deliberate intention of the author (which can occur to a limited degree through the use of metaphor). To be fair, Ingram and Salyer do not accept that Qohelet can be read any way that the reader wants to read it. Rather, they appeal to the work of Wolfgang Iser in arguing that determinate schemata and structure constrains the reader, by way of authorial intention, to read the text as deliberately ambiguous (Ingram, Ambiguity, 37-43 and Salyer, Vain Rhetoric, 90-108). Bringing this back to the ambiguity of the הבכל symbol, it might be said that one aspect of the הבל symbol is to communicate through ambiguity the various families represented by the symbol, not the least of which being enigma. For further reading, see Wolfgang Iser, "Indeterminancy and the Reader's Response," et al., Twentieth Century Literary Theory (New York: Columbia University Press, 1971), 226-31.

${ }^{85}$ Miller, Symbol and Rhetoric, 155.
} 
foulness of the stated observation. ${ }^{86}$ In this manner the הבל symbol functions in such a way so as to incorporate statement and judgment, description and evaluation, and the various families of meaning, along with all the variable nuances intrinsic within each family, into any given portion of Qohelet's line of argument, all the while remaining reflective of the whole. Through the "qualitative superiority" of the הבל symbol, Qohelet is thus enabled to describe, evaluate, and fret over the totality of the human condition as observed and experienced in this fallen world. ${ }^{87}$

While the scope of this work does not allow for a full exegetical treatment of the 38 occurrences of the הבל metaphor in Qohelet, it would be profitable to survey a few cases representative of each family of meaning. The objective of this survey is to demonstrate the flexible nature of the metaphor, and in completing the survey, to support the thesis that the matif can only be understood and fully appreciated when the idea of metaphor is expanded to that of "symbol" in the comprehensive sense communicated by the הבל concept in Qohelet.

\footnotetext{
${ }^{86}$ Miller further describes this relationship: "He addresses things which he believes should not be insubstantial or transient, and thus there is an evaluative implication to such descriptive hebel- statements. Qohelet wishes that the period of youth would endure longer, wisdom has limits which one could wish were otherwise, and so on (Miller, Symbol and Rhetoric, 155)." Fox too argues for an overriding evaluative sense to those descriptions which are enigmatic or incomprehensible. It is at least in part for this reason that Fox elects to use the term "absurd" in glossing meaning. See Fox, "The Meaning of Hebel," 411.

${ }^{87}$ Miller continues this line of thought by concluding, "Finally, there is a complex cognitive content to hebel as symbol, although the attempt to summarize it demonstrates the qualitative superiority of the symbol itself: the human situation in this world is such that effort does not always accomplish, experiences do not satisfy, security is elusive, some things are frail and do not last, yet others are frustratingly mysterious, and others are disgusting (Miller, Symbol and Rhetoric, 155)."
} 
The Transience Family

Although debate exists as to its prominence, even scholars who take a unilateral approach

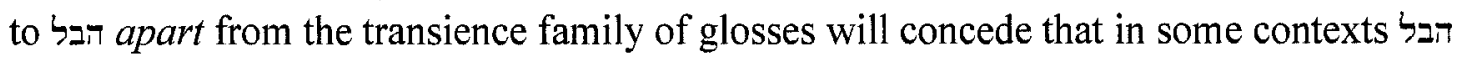
is best translated as "brevity" (or another gloss within the transience family of options). ${ }^{88}$ Not only is this sense clearly distinguishable in Qohelet's use of הבל, it is also supported elsewhere in the Hebrew Bible as descriptive of the short span of human life (Ps 39:5-6; 12 [Hebrew]; 144:3-4, 11). ${ }^{89}$ Although many other cases of in the Hebrew Bible, can be construed to imply a sense of brevity (and perhaps rightly so), ${ }^{90}$ it is in these contexts speaking of the human lifespan that the transience family most clearly takes lexical precedent.

As Qohelet speaks of the brevity of human life, he uses guarding terms such as the synonym (shadow) and the phrase "few days" to further support the connotation of transience. Perhaps the clearest examples in Qohelet where the transience family is employed are 6:12 ("For who knows what is good for a man in life, during the few and

${ }^{88}$ While Fredericks has chosen to take an approach where "transience" is the primary meaning conveyed through the metaphor, others have suggested that it is the metaphoric sense least employed in Qohelet (Miller, Symbol and Rhetoric, 95). Nevertheless, the few cases where transience is the favored sense of the metaphor are strikingly clear, so much so that even Fox concedes that "in 12:1 it is evident that the brevity of the time of youth is at issue here." See Fox, "The Meaning of Hebel," 421.

${ }^{89}$ See Fredericks, Coping with Transience, 19-20 and Miller, Symbol and Rhetoric, 95.

${ }^{90}$ For instance, הבל is used in Proverbs 31:30 to describe beauty, which in a woman is certainly as fleeting as it may be vain. Note too that this case of (Prov 31:30) is translated as "fleeting" in the NIV, "passing" in the NKJV (but "vain" in the KJV), and "vain" in the NASB. These observations are interesting in light of the fact that the NIV avoids translating הבל with any gloss from the transience family in Qohelet, while ironically the NASB is at least willing to translate הבל as "fleeting" in Qoh 11:10. These comparisons simply point out the ambiguous yet multivalent sense in which הבל communicates multiple concepts from multiple families, with many contexts allowing for multivalency. Reflecting this kind of inter-dependence and multivalency, Fox comments in regard to Proverbs 31:30, "Physical beauty is deceitful precisely because it is ephemeral (Fox, A Time to Tear Down, 40)." 
הבל days he passes through like a shadow?") and 11:10 ("So then, banish anxiety from your heart and cast off the troubles of your body, for youth and vigor are ${ }^{2}$ "). ${ }^{91}$

As for $6: 12$, the preceding proverbial statements $(6: 7-11)$ focus on cases of irony and insubstantiality observed "under the sun," yet in the immediate context of 6:12 a clear translation of הבל would describe the years of a man's life as "few and fleeting," passing through like a "shadow," thus depicting that which is transient. ${ }^{92}$ In the case of 11:10, the sense of the mבל mophor is less dependent upon guarding terms and synonyms and more a product of context. The coming days of darkness and the allegory which follows suggests that the vigor of youth is fleeting; the exhortation to enjoy life in one's youth and take advantage of the opportunities of the present add emphasis to the urgency associated with taking advantage of time that is quickly passing by. ${ }^{93}$ In both cases, a most natural reading of the הבל metaphor primarily draws from the transience family of meaning. ${ }^{94}$

\footnotetext{
${ }^{91}$ The English translations in this example are taken from the NIV. For other examples from Qohelet where the brevity of the human lifespan is reflected upon, see 2:3 and 5:18 [Hebrew 5:17].

92 The term shadow (ל:) can be demonstrated as having a wide semantic range as used metaphorically in Ecclesiastes and elsewhere. For example, the word describes a "shelter" in 7:12, as it is commonly used metaphorically elsewhere in the Old Testament to describe a shelter of protection (cf. Job $40: 22$; Hos 14:8). Ironically, in $8: 13$, the term "shadow" is used to depict that which lengthens, or "long life," the exact opposite of how it is used in $6: 12$.
}

${ }^{93}$ In 11:10, the imperatives to "banish anxiety" and "cast off the troubles of your body" are understood by advocates of the transience view as injunctions to enjoy life while there is time; certainly, the short time of opportunity contributes to the urgency in Qohelet's enjoy life imperatives (9:7-9 and 11:9). It is also noteworthy that the inevitability of death prompts one to a sense of urgency. As one meditates upon the inter-dependency between the inevitability of death and the enjoyment of life, the transience family of meaning within the הבל symbol becomes all the more relevant. On transience, הבל the inevitability of death, see Burkes, Death in Qoheleth, 45-48.

${ }^{94}$ While Fox agrees in principle that these two references (and others which describe living beings as, including 3:19; 7:15; and 9:9) may refer to life's "ephemerality," he nevertheless contends that the connotations of absurdity are apparent within these references as well. Fox's logic is as follows: Due to the preponderance of occurrences where הבל means absurdity, such an overriding concept is also influential here. For instance, "though youth is precious, it (like wisdom), is rendered absurd by its brevity." See Fox, A Time to Tear Down, 39-40 and "The Meaning of Hebel," 421. 
The Vanity Family

Due to the influence of our English translations, the most influential being the KJV, it is the vanity family of glosses, represented by terms such as "vanity," "insubstantiality," "futility," and "emptiness," that comes to most people's minds when they think of the book of "Ecclesiastes" (even if they have little familiarity with the Hebrew text, Qohelet,

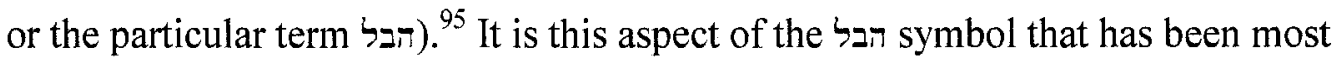
influential in prejudicing the general population in taking an overly pessimistic approach to the book as a whole. The pessimism intrinsic within this family of glosses is valid; however, the הבל referents speaking of insubstantiality, futility, and emptiness must too be understood contextually within the framework of the הבל symbol, and even more critically, they must be understood within the context of Qohelet's greater line of argument. $^{96}$

Apart from the role to which these referents play within the הבל symbol (and by default, the הבל motif), one should realize that Qohelet never observes, infers, or endorses the idea that life or any other thing is "purposeless." ${ }^{.97}$ Rather, the "vanity" referents

\footnotetext{
${ }^{95}$ Miller refers to this family as "insubstantiality referents." He also includes "transience referents" and "foulness referents" in his assessment of the rymbol. The one set of referents that he gives little attention to, or diminishes to the extent of incorporation into the above three sets, are those referents which I see in the "irony family" of glosses. See Miller, Symbol and Rhetoric, 92-97.

${ }^{96}$ The greater line of argument must consider the many prominent motifs within Qohelet, not simply the הבל motif, much less just one aspect of the הכל motif appoach that considers the interdependency between the motifs will make it difficult to allow for any approach that elevates the prominence of pessimism to the exclusion or diminishment of optimistic imperatives.

${ }^{97}$ Although the terms can be variously understood as near synonyms, there are nuanced distinctions. Qohelet does not contend that life or anything else is without purpose, nor does he imply that his quest is for purpose. Due to these misconceptions, popular Christianity has erroneously taught that Qohelet's message communicates that life without God is purposeless, and that Qohelet is in the canon simply to demonstrate that life without God has no purpose. For this reason the NIV's uniform translation is especially poor; not only does it fail to consider the variety of meanings inherent within Qohelet's use of
} 
describe situations wherein human effort and its various pursuits described as "toil" (עכנל) fall short of reaching the goal of תרון, the gain or advantage that lies out of the reach of mortal man. 98 As pertaining to the "vanity" aspect of the הבל symbol, יתרון takes on the role of a "negated contrary term," meaning that if הבל equates to that which is empty or insubstantial, then יתרון refers to that which is "excess," "surplus," or in a metaphorical sense, "advantageous." symbol by complimenting his use of הבר with and its various associated terms such

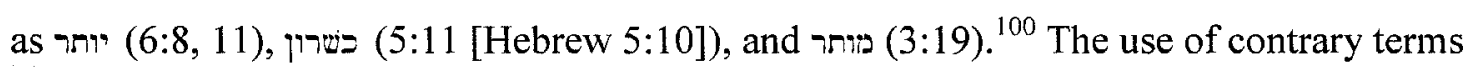
set within select contexts functions within the text to highlight the sense in which הבל is empty and insubstantial. Taken one step further, when the הבל metaphor is applied to contexts accentuating the limits of human effort, the pursuit of יתרון is seen to be practiced in vanity and is destined to ultimate futility.

The existence within the הבל symbol of the vanity family of glosses becomes all the more obvious when seen in light of the common guarding phrase, רעות, which is variously translated as "chasing the wind," "shepherding the wind," "the wind's desire," "vexation of spirit," and "windy thoughts."101 The exegetical difficulties inherent in

the הבל symbol, it also misunderstands the "vanity" referents to be speaking of a concern that is never apparent within the text of Qohelet.

98 יתרון functions within Qohelet as the goal of his inquiry, and as such, it will be later considered as to its programmatic relationship to the הבל motif (Qoh 1:3).

${ }^{99}$ Miller, Symbol and Rhetoric, 92. The Theological Dictionary of the Old Testament stresses the "dominant role" "תרון" plays as a means to "force upon hebhel the special sense of "that which does not count or matter,' 'null,' 'vain,' 'that which yields no results.'" See Botterweck and Ringgren, TDOT, vol. 3, 319.

${ }^{100}$ Miller, Symbol and Rhetoric, 92.

${ }^{101}$ This guarding phrase is prominent in the first half of the book, but lacks presence in the second

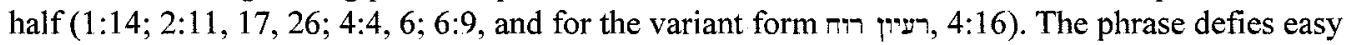
translation due to the fact that both words, רות רות contain a certain degree of ambiguity based upon 
translating the phrase have allowed for various interpretations in regard to the phrase's

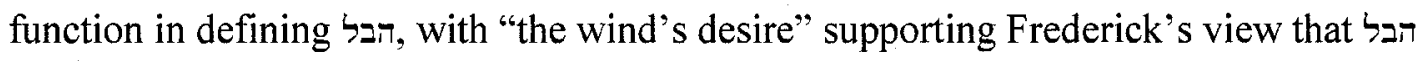
always emphasizes transience, “windy or senseless thoughts" supporting Fox's gloss "absurd," and "vexation of spirit" giving allusion to the "foulness" family of referents. ${ }^{102}$ However, the most natural exegetical understanding of רעות רוח, along with the most contextually sensitive approach, strongly favors a translation suggestive of vanity, futility, or any other number of glosses coming from the insubstantiality, or vanity, family of meaning. ${ }^{103}$

Surveying any one of the הבל statements guarded by רעות רוז would suffice to demonstrate the ability of the הבל symbol to convey this aspect of futility. For the sake of concision, we will look at the section from 1:12 through $2: 26$, wherein the phrase accompanies הבל four times $(1: 14 ; 2: 11,17,26)$ and stands on its own once $(1: 17)$. The

difficulty ascertaining the lexical root of רעות (from one might see the root meaning "to pasture, tend, or graze," "to associate with," or "to desire," and from רעy, one might derive "vexation," from "to break"), and the metaphoric sense of רוח ("spirit," "wind," or "breath"). For a more detailed analysis regarding the exegetical choices and ambiguity inherent in this phrase, see Ingram, Ambiguity, 111-14.

${ }^{102}$ The combined ambiguity of the term and its guarding phrase leads to the propensity for interpreters to naturally define each term based upon pre-set notions regarding the definition of the parallel term, so that Fox is veered towards the translation "windy thoughts," Fredericks is prompted to understand the phrase as a subjective genitive, translated as "the wind's desire," thus reinforcing the idea of transience, etc ... Fredericks can thus argue that the "phrase would then be metaphorical just as hevel is, connoting the brevity of life and its experiences which are like the wind's desire that changes from the north to south, east to west, downward, upward, around and even virtually still (Fredericks, Coping with Transience, 30)." Likewise, Fox takes "windy thoughts" to mean "senseless thoughts" in reference to the chaos and absurdity alluded to by the restless nature of the wind (Fox, A Time to Tear Down, 42-48).

${ }^{103}$ Miller argues that these phrases and their occurrence within the motif must be understood in relationship to human toil and effort, a context that Fox "unduly downplays" (Miller, Symbol and Rhetoric, 93). Miller further argues that "the contexts in which Qohelet uses them [the guarding phrases] as well as similar metaphorical uses of wind indicate the attempt to achieve the impossible. Though toil, wisdom, goodness, and popularity have been achieved, the quest for 'surplus' is not attained (Miller, Symbol and Rhetoric, 94)." For more on the exegetical support for the objective sense of the phrase ("shepherding," "desiring," or "chasing" the wind), along with its primary allusion to the insubstantiality family of referents, see Miller, Symbol and Rhetoric, 92-95; Christianson, A Time to Tell, 84-85; Crenshaw, Ecclesiastes, 68-73; Ogden, Qoheleth, 21; and David A. Hubbard, Ecclesiastes, Song of Solomon, The Communicator's Commentary (Dallas: Word Books, 1991), 62. 
initiation of a new section, the "royal experiment," is made evident by the employment of the first person and autobiographical persona. ${ }^{104}$ Throughout this section Qohelet presents a multitude of subjects quintessential to his work, including toil, wisdom, and pleasure, but it is his concern over the inability of human effort to result in that frames the section (1:14, "I saw all the works ...," and 2:26, "I saw all the deeds ...") and drives him to his conclusion over the entire section: "I saw all the deeds that are done under the sun; and indeed, all is רעות רוז and (2:26)." Within these texts that wrestle with the effectiveness of human effort and toil in attaining הבל metaphor, in conjunction with its guarding phrases, functions most naturally as a means to describe vain effort, a futile pursuit for a goal that is ultimately unattainable.

Even while the prominent sense of the הבל statements in this section describes the inability of human effort to attain a particular goal, there is a sense in which the multivalent flavor of the הבל symbol lends itself to complimentary connotative addition. In 1:13, Qohelet uses the modifying term רע to give a negative evaluation to the whole issue regarding the inability of human effort to achieve תרון, thus suggesting a dimension of the evaluative "foulness" aspect of the הבל symbol for those הבל references within the $1: 12-2: 26$ pericope. ${ }^{105}$ Furthermore, the failure of wisdom $(1: 16-18 ; 2: 12-17)$ is not simply described in the sense of futile effort; it is also described as an "affront to human reason," for the same destiny awaits both the fool and the wise. This too is described as הבל , once again heightening the sense of multivalent necessity in understanding the function of as contexts and guarding phrases are not always distinguishable in any

\footnotetext{
${ }^{104}$ Miller, Symbol and Rhetoric, 105.

${ }^{105}$ Ibid, 107.
} 
clear and decisive manner. ${ }^{106}$ Nevertheless, the combination of context and attendant guarding phrases demonstrates sufficient "nuance" so as to validate the presence of "vanity" or "futility" within Qohelet's הבל symbol, and ultimately, within the whole motif.

\section{The Irony Family}

Tבל The "irony family" of meaning contains multiple nuanced connotations within the symbol, with possible glosses including words such as "enigmatic," "ironic," "incomprehensible," "mysterious," "inscrutable," "elusive," "senseless," and "absurd."107 In various contexts each of these glosses may find application, with terms such as "enigmatic," "incomprehensible," and "mysterious" implying a neutral judgment regarding "mysteries which are unfathomable to his [Qohelet's] finite mind,"108 and terms such as "senseless" and "absurd" implying an aspect of negative judgment based

\footnotetext{
${ }^{106}$ In describing הבל as absurdity, or "an affront to human reason" in this section's collection of הבל statements, see the commentary in Fox, A Time to Tear Down, 171-74 and 181-84.

${ }^{107}$ Although much of my own thinking on Qohelet's use of the word has been influenced or reinforced by Miller, I feel that Miller leaves out one of the more important families of meaning, if not entirely, then at least by way of categorical designation. Perhaps the inadequacy of Miller's categories is demonstrated by Frydrych when he states, "In my view the best analysis of the meaning [of han] is that of Miller (1998) who argues that הבל with its original meaning vapour is used by Qoheleth as a symbol that encapsulates the notions of insubstantiality, transience and foulness, summarizing Qoheleth's evaluation of human experience," yet decides to adopt Fox's "absurd" as his gloss of choice throughout his own work (Frydrych, living under the Sun, 45-46). My own approach is to see not three categories, but rather four categories, or "families of meaning," to which the hevel symbol refers. This fourth category not cited by Miller is that of the "irony family," through which the connotation of Fox's "absurd" is communicated.

${ }^{108}$ W. E. Staples, "The "Vanity' of Ecclesiastes," JNES 24 (1943): 104. The tendency of most commentators espousing the glosses within the "irony family" as the best representation of Qohelet's use of the hevel metaphor is to select a neutral term. Thus one finds Ogden and Zogbo, Wilson, and Bartholomew using the term "enigmatic," Seow using "incomprehensible," and Provan suggesting "elusive" to describe man's perspective of reality. See Graham S. Ogden and Lynell Zogbo, A Handbook on Ecclesiastes, UBS Handbook Series (New York: United Bible Societies, 1997), 4; L. Wilson, "Artful Ambiguity in Ecclesiastes 1, 1-11," in Schoors, ed., Qohelet in the Context of Wisdom (Leuven: Leuven University Press, 1998), 362; Bartholomew, Reading Ecclesiastes, 166; Seow, Ecclesiastes, 102; Provan, Ecclesiastes, 52.
} 
upon man's perception of reality. ${ }^{109}$ Thus the connotation of mystery implies a simple lack of understanding, but in many contexts Qohelet stretches a lack of comprehension regarding God's activity to also include a perception of reality, a judgment regarding how things should be. Furthermore, the "irony" family of meaning also includes expressions of "enigma" and "irony," thus connoting that what Qohelet observes often runs counter to his expectations. ${ }^{110}$ The symbol is thus inclusive enough, even within this single family of meaning, to include reference to observations which are at once mysterious (a neutral judgment based in one's lack of understanding), ironic (a neutral judgment wherein normal expectations are not met), and absurd (a negative judgment wherein human reason is offended). ${ }^{111}$

A clear case of multiple הבל judgments drawn from the irony family of meaning exists in the passage Qoh 8:10b-14. Assuming that the judgment at the close of verse 10 actually introduces a new passage rather than concludes a preceding one (as suggested

${ }^{109}$ For the classic treatment of "absurd" as a gloss for הבל, see Fox, A Time to Tear Down, 30-35. Christianson affirms Fox's view, and compliments his contributions well by treating Qohelet's use of within the framework of narrative. See Christianson, A Time to Tell, 79-95.

${ }^{110}$ Christianson agrees that "some element of irony is surely entrenched in Qohelet's use of הבל" but adds that "irony" or "ironic" would be inappropriate as a translation due to the understanding that irony interprets the observation, and this presumably is the work of the reader, not the author (Christianson, $A$ Time to Tell, 86-87). However, I would suggest that Qohelet does interpret his observations, sometimes viewing them as ironic, sometimes as absurd, and sometimes as both. For the view that has a fully ironic sense, see Edwin Good, Irony in the Old Testament (Sheffield: Almond Press, 1981), 27, 182 and T. Polk, "The Wisdom of Irony: A Study of Hebel and its Relation to Joy and Fear of God in Ecclesiastes," SBTh 6.1 (1976): 3-17.

${ }^{111}$ Fox, who believes that within the semantic field of the "counter-rational," הבל should always be rendered as "absurd", is nevertheless helpful in distinguishing between these terms. For Fox, the sense of the "incongruous" or "ironic" is "too soft," describing that which may be merely "puzzling or amusing," but failing to express the sense of oppression which Qohelet conveys in his ponderings. He further clarifies the distinctions between the mysterious or incomprehensible, which he describes as "asserting the limitations of human reason," and the absurd or senseless, which is "an affront to human reason." Although I agree that the sense in which Qohelet uses הבל is laced with judgment, I choose to relegate that to the "foulness" family of meaning within the תבל symbol, all the while understanding that the הבל symbol, as remaining fluid even within a select family of meaning, may permit the nuance of "absurdity" as an aspect of the "irony family." See Fox, A Time to Tear Down, 30-35. 
by the Masoretic verse division), we find the passage $8: 10 \mathrm{~b}-14$ framed by a "this too is "הבל inclusio and heightened at the beginning of verse 14 by "something else הבל that occurs on the earth," namely, the height of injustice: "the righteous getting what the wicked deserve and the wicked getting what the righteous deserve." 112

The emphasis in this judgment is clearly not "transience" or "vanity," but rather, a sense of injustice stemming from a situation which might first be described as "ironic" to the impartial observer. However, Qohelet is hardly impartial; for him, the situation is an "affront to human reason," or "absurd." Furthermore, Qohelet is offended not simply as to his human sensibilities, but even as to his faith; conventional, theistic wisdom would demand that the righteous not get what the wicked deserve, and vice versa!

The complex irony within this passage is heightened by the observation that injustice encourages wicked men to scheme all the more (8:11); however, the faith that Qohelet retains reminds him that "it will go better with God-fearing men who are reverent before God" (8:12), and that "because the wicked do not fear God, it will not go well with them, and their days will not lengthen like a shadow $(8: 13) . " 113$ The tension

${ }^{112}$ Fox takes the הבל judgment in $10 \mathrm{~b}$ to introduce a new passage rather than conclude the preceding one (against the Masoretic verse division and "most commentators"). However, he concedes that "whether the clause is applied to v. 10a or vv. 11-13, the meaning of hebel is the same, because both the preceding and the following passages describe an unjust, absurd situation. If "this too is an absurdity" looks forward, the "too" shows that the preceding likewise is an absurdity (Fox, A Time to Tear Down, 28485). If the limited (במל judgment in 8:10 describes the preceding scenario, it likely applies to 8:9 and 8:10. Furthermore, in verse 9 an ironic situation is observed; a situation where a man seeking power does so to his own harm. In verse 10, an injustice is observed as the wicked receive respect even in death. For Qohelet this is an absurd affront to reason, an injustice that cannot be fathomed in light of God's supposed judgment. The progression in verses 9 and 10 is suggestive of multivalency of nuanced connotation even within the irony family of meaning.

${ }^{113}$ Interpreters have erroneously sought to "remedy" this apparent contradiction by appealing to the work of "pious redactors" seeking to bring the passage into conformity with tradition, or by suggesting that Qohelet is quoting the tradition, thus resulting in dynamic and interpretive translations such as the TEV, "Oh yes, I know what they say ..." However, the passage is best seen as reflecting the tension between observation and faith, or the principle of retribution as contrasted with the occasional exception that occurs as a result of living in a הבל world. 
between faith and observation, the "zwar-aber" reflections heightened by the sheer irony of the said observation, are altogether suggestive of the mystery behind God's judgments. ${ }^{114}$ In this sense, the metaphor encapsulates the full range of nuance available through the irony family of meaning, if not also drawing in a limited sense from the "frustration" family as well. ${ }^{115}$

\section{The "Frustration Family"}

The "frustration family" is difficult to define and even more difficult to designate with a representative gloss, but options include such terms as "foulness," "disgusting," frustration," and any number of negative evaluative expletives. Whereas other families within the הבל symbol are descriptive as well as evaluative, this family is exclusively evaluative, utilizing the metaphor to describe vapor which has become "bad air," something repulsive and overtly negative in Qohelet's estimation of reality. ${ }^{116}$ Miller describes this use of הבל as describing realities which are "an affront to Qohelet's sense of justice," a definition that reminds us of Fox's definition of the "absurd," and thus also reinforces the notion of multivalency within the הבל symbol. ${ }^{117}$ Furthermore, the connotation of "frustration" is not too dissimilar to that of "futility," thus drawing upon evaluative and negative aspects of the "vanity family" of meaning. However, given the

${ }^{114}$ The tension inherent in these verses is itself indicative of mystery, irony, and absurdity as outlined above. It is as if Qohelet observes that which is an affront not only to human wisdom, but also that which is an affront to traditional Hebrew wisdom. In this sense he is expanding his own perception of wisdom to include not only the rules, but also the exceptions. As a sage, however, Qohelet is quick to affirm the wisdom of righteousness, even in spite of the exceptions.

${ }^{115}$ As suggested earlier, the connotations available in the term "absurd" involves enough of a negative judgment to allow the word to stand on its own within the "irony family," although one could just as easily allow for multivalency from across separate "families" of meaning within the הבל symbol.

${ }^{116}$ Miller, Symbol and Rhetoric, 95.

${ }^{117}$ Ibid. 


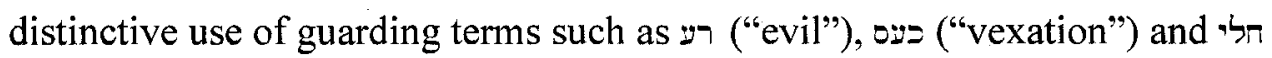
("sickness"), coupled by their adjectival use in association with topics assessed as being הבל , one cannot help but recognize a distinctive sense in which some things evaluated by Qohelet are revolting to his senses. ${ }^{118}$

The "frustration" or "foulness" family of meaning is primary in numerous judgments, these being especially clear in cases guarded by the above stated negative guarding terms. For instance, even though other aspects of the הבל symbol can be argued to be at the root of Qohelet's negative judgment, one cannot help but sense the frustration in the following scenarios: 1) wealth passed along to one who has not labored for it $(2: 21$, "This too is רעה רבה ['a great evil']"), 2) wealth that is not passed along due to a lack of an heir (4:7, "This too is ענין רע and ['an evil occupation']"), הבל ${ }^{\prime 19}$ and 3) wealth which is not enjoyed by the one who earns it and is rather enjoyed by another $(6: 2$, "This is and ['a grevious evil']"). situations where the term הבל is not present, but with the הבל motif so pervasive throughout the book, the connection is never distant in thought if not in word. ${ }^{121}$

${ }^{118}$ Guarding terms and modifying phrases are found throughout Qohelet, seven times in textual association with הבל, and another 24 times in association in the broadest sense of thematic relationship. Polk sees the terms הבל and as and a synonyms, but I prefer to see as a gurding term describing only certain aspects of the nבsybol as certain situations are evaluated, with or without direct textual alignment with the term הבל. See Polk, "Wisdom of Irony," 9 and Miller, Symbol and Rhetoric, 96.

${ }^{119}$ One should not miss the irony here; Qohelet is at once describing the situation of a man with an heir as well as the man without an heir as both being הבל. Perhaps even in the specific judgments of disgust and frustration, Qohelet recognizes the irony between these scenarios.

${ }^{120}$ It is a noteworthy observation, if not exegetically significant, that Qohelet uses similar guarding phrases alongside הבל to describe situations involving wealth, toil, and its dispersion to others.

${ }^{121}$ See for instance judgments regarding oppression (4:1-3) and equity in death (9:3). 


\section{הבל The Dilemma of}

In developing an understanding of the transition from הבל as symbol to הבל as motif, one must recognize the importance of the relationship between the key terms הברון and If the omnivalent הבל symbol is presented within Qohelet as intrinsically negative, or even if in select circumstances it can be understood as neutral, then it is reasonable to suggest that Qohelet is fundamentally dissatisfied with that which he describes as הבל.

Understanding that the הבל motif depicts not the ramblings of a misguided pessimist, but rather, the reality of human experience in a fallen world, one must then approach the הבל motif with a view towards Qohelet's plan and purpose as he reflects upon its existence.

The didactic nature of Qohelet's reflections and sayings are quite clear, noted especially in the progression of the book and the line of argument that incorporates staged conclusions and proverbial wisdom. With this in mind, the purpose in the text is clearly not to simply gripe and complain about the way life is, even if in doing so an accurate reflection of reality is conveyed. Similarly, Qohelet's purpose is not to simply provide snippets of proverbial wisdom set within the context of experience; his line of argument is far more complex than that of other compilations of proverbial wisdom such as that found in the canonical book of Proverbs. Rather, Qohelet has embarked on a quest to find a solution to the "dilemma" of to discover if there is anything that wisdom may offer that will in some way absolve the situation of "hevelness" reflected in the reality of life experienced in a fallen world. ${ }^{122}$

\footnotetext{
${ }^{122}$ For the correlation between Gen 1-3 and Qohelet, especially as it pertains to Qohelet's conception of the הבל motif and the nature of the post-fall world, see Charles C. Forman, "Koheleth's Use of Genesis," JSS 5 (1960): 256-63; Hans Wilhelm Hertzberg, Der Prediger (Gutersloh: Verlagshaus Gerd Mohn, 1963), 227-31; Robert Gordis, Koheleth, the Man and His World: A Study of Ecclesiastes, $3^{\text {rd }}$ ed. (New York: Schocken Books, 1968), 43; Jeffrey Meyers, A Table in the Mist: Ecclesiastes through New Eyes (Monroe, Louisiana: Athanasius Press, 2006), 44-45; Duane A. Garrett, Proverbs/Ecclesiastes/Song
} 
Central to understanding the quest of the "Quester" is the determination of the goal of his inquiry. ${ }^{123}$ Serving as an introduction to the literary quest which follows, the "programmatic" question is asked in Qoh 1:3, "What יתרון is there for a human being in all his labor at which he labors under the sun?" Taken as a programmatic question of inquiry rather than a rhetorical statement of fact, this question then serves to introduce the reader to the quest in which Qohelet embarks and the goal to which Qohelet pursues. ${ }^{124}$ The key word in this question is תרון, a term understood in its literal sense to refer to "that which is left over when all the transactions are added up," 125 or in other words, a "profit," "gain," or "surplus." 126 In a more distant sense, the term could refer to an

of Songs, New American Commentary (Nashville: Broadman, 1993), 278-79; Whybray, Ecclesiastes, 2830, and Eaton, Ecclesiastes, 46. A unique (but not altogether inaccurate) perspective regarding Qohelet's perception of and the reality of life in a post-fall world is that of David M. Clemens, who correlates the two in translation: "The term [הכל] is so loaded with meaning that it virtually defies a unitary English translation; but perhaps 'fallen' (i.e., expressive of and/or destroyed by the fall) can capture most of its connotations within E[cclesiastes] ( $c f$. Rom. 1:21;8:20)." I am inclined to agree with Clemens in theory; the הבל symbol, as well as the הבל motif, are both reflective of the results of life and reality as it exists in the post-fall world. See David M. Clemens, "The Law of Sin and Death: Ecclesiastes and Genesis 1-3," Themelios 19 (1994): 7.

${ }^{123}$ For an insightful (although inadequate) replacement gloss for Qohelet ( $\Omega$ Sinp), see Eugene H. Peterson's use of "Quester" in The Message: The Wisdom Books (Colorado Springs, NavPress, 1996).

${ }^{124}$ The word "programmatic" has become standard among commentators who view the question as inquiry rather than as statement. See Christianson, $A$ Time to Tell, 219; Ogden, Qoheleth, 28; Salyer, Vain Rhetoric, 141; Bartholomew, Reading Ecclesiastes, 241. Frydrych views the question as rhetorical, yet sees its function as "introductory, serving as a headline focusing the following discourse (Frydrych, Living under the Sun, 44)." However, as an introduction, it seems best to simply understand the question as real inquiry, thus introducing the quest as being open to its conclusion, at least as known from the diachronic perspective of the reader.

${ }^{125}$ Frydrych, Living under the Sun, 45 . The TDOT follows this same pattern, emphasizing the connotation of "surplus" or "gain," but does hint at an expanded and nuanced range of meaning particular to Qohelet. See G. Johannes Botterweck and Helmer Ringgren, Theological Dictionary of the Old Testament, vol 6 (Grand Rapids: Eerdmans, 1990), 489-91.

${ }^{126}$ The term יתרין stems from the verbal root defined variously as "to remain over," "to be extra," "to leave surplus," or in the niphal, "to be left over". See the discussion by David Latoundji for a thorough treatment (VanGemeren, ed., Dictionary of Old Testament Theology \& Exegesis, vol 2, 571-74). The term יתרו is found only in Qohelet (10 times), although it does exist in extra-biblical literature. Regarding the possible impact of post-biblical Hebrew on Qohelet's use of the term, Whybray states, "in post-biblical Hebrew yitron can mean 'addition,' 'even redundancy,' or 'worthlessness' (the state of being surplus to requirements). Consequently it is not a simple matter to determine exactly what Qohelet intended 
"advantage," and in the case of the programmatic question, חרון carries the sense of advantage or leverage through which one may gain control in a world in which he has no control, a sense of leverage that may equate to the power of provision for the solution to the dilemma of הבל.

If the "original commercial application" of 9 " is not the primary focus of Qohelet's use of תרון, then to what does the term apply? ${ }^{128}$ While commentators have been open to understanding Qohelet's use of יתרון as extending beyond the mundane benefits of financial gain, there is a general lack of continuity regarding the exact referent to Qohelet's use of יתרון ${ }^{129}$ Scholars have variously understood תרון' as a reference to the earthly ideals of "contentment," "130 "complete satisfaction,", or "true human fulfillment," 132 while others have suggested a meaning that "seems also to incorporate the by it (Whybray, Ecclesiastes, 36-37)." For an excellent survey of commentators and their preferred approaches to the translation of תרון", see Ingram, Ambiguity, 131-34.

${ }^{127}$ To interpret and translate "תרון as "advantage" is common among commentators. See for instance Fredericks, Coping with Transience, 48; Fox, A Time to Tear Down, 112-13; Ogden, Qoheleth, 28; Seow, Ecclesiastes, 100. However, to understand יתרו" as "advantage" or "leverage" is admittedly interpretive, the result of an exegesis based in thematic context more so than lexical analysis. Robert Johnston hints at this by stating, "In his work (amal) at mastering life, Qoheleth was seeking to gain some advantage over (yitron), some profit-some leverage in which he might approach his world as its master." Meyers too affirms such an approach by stating that "(yithron) refers to gaining 'leverage' in the worldsome sort of advantage," this coming on the heels of stating that "the point [of hevel] is that there is no advantage or ultimate leverage in our work." See Robert K. Johnston, "Confessions of a Workaholic," $C B Q$ 38 (1976): 20 and Meyers, Table in the Mist, 43.

${ }^{128}$ Ogden, Qoheleth, 25.

${ }^{129}$ Ingram uses this lack of consensus regarding intentional ambiguity in the authorship of Qohelet. See Ingram, Ambiguity, 130-149.

\footnotetext{
${ }^{130}$ Hubbard, Ecclesiastes, 45.

${ }^{131}$ Ibid.

${ }^{132}$ Tamez, When the Horizons Close, 36.
} 
possibility of some experience beyond death. $" 133$ While most scholars are quick to reject an eternal dimension to Qohelet's use of,${ }^{134}$ the connotation does seem to extend beyond the domain of terms such as fulfillment, contentment, and satisfaction. In conjunction with the various nuances implied through the above stated terms (advantage, leverage, gain, satisfaction, contentment, fulfillment, and the like ...), I would suggest that whatever entails, it must correlate directly to the omnivalent concept depicted in the motif, originating in the fall, and reflective of the reality of life experienced in a fallen world. In this regard, I would suggest that Qohelet's quest for תרון, as balanced against his understanding of the world as הבל, equates to a "solution" or an "answer" to the "dilemma" of הבל Attempting to pinpoint down an exact description of what this "solution" or "answer" entails is difficult to do, if not for any other reason than the fact that Qohelet himself likely did not know the exact content of that which he was searching for.

If the הבל motif is best understood in relationship to Qohelet's purpose in finding יתרין, then the question remains: Did Qohelet ever find what he was looking for, did he ever find a solution to the dilemma of הבלל? The short answer to the question is no, Qohelet did not find יתרון. The evidence for this is circumstantial, but strong. Proportionally, the term יתרון is weighted towards the front end of the book, where Qohelet's first person experiences and reflections give way later to second person

${ }^{133}$ Ogden, Qoheleth, 29.

${ }^{134}$ Frydrych is quite adamant in stating that "[yitron] certainly does not refer to an advantage in the afterlife... (Frydrych, Living under the Sun, 45)," emphasis mine. Ingram too suggests this consensus in stating that Murphy "expresses the view of a number of commentators when he states simply, "What seems clear is that יתרון is not bound up with an eternal dimension (contra Ogden)." See Ingram, Ambiguity, 133 and Murphy, Ecclesiastes, 1x. Personally, I am open to the possibility that may hint at some form of gain or advantage in the afterlife, although the term does not apply exclusively to eternal rewards. 
instruction and imperative. ${ }^{135}$ Furthermore, the term יתרון takes on its broadest programmatic sense only in $1: 3$ and $3: 9$; in other contexts, especially those within selfcontained proverbs as found later in the book $(7: 12 ; 10: 10-11)$, the term is best understood in its more traditional, less "loaded" sense. ${ }^{136}$ However, the most telling evidence that Qohelet never finds יתרון is the simple fact that there is no evidence in the text that claims that his goal was ever reached, that תרון was ever found! Rather, as the text progresses, there tends to be a shift in program, ${ }^{137}$ a general concession that while " may not be found (at least on this side of eternity), there is still a portion given by God to the one who will receive it. ${ }^{138}$ Thus, the nature of his inquiry is such that the reader is not left in a state of despair; Qohelet redirects his course, arrives at conclusions which first seem concessional but are later deemed affirmational, and enlightens the reader by espousing the benefits of wisdom as experienced in a הבל world.

Qohelet presents the reader with a picture of reality as it is observed and הבל motif; without a proper understanding of the motif, the reader will be unable to track the line of argument and the vital inter-dependency between the key motifs in the book of

\footnotetext{
135 The first person observational/second person instructional division is well recognized as a trend, but as Ingram suggests, "Ecclesiastes resists any attempt to impose upon it (or discover within it) a tidy overarching structure... (Ingram, Ambiguity, 131)."

${ }^{136}$ Frydrych, Living under the Sun, 45 .

${ }^{137}$ Frydrych correctly observes that "instead of being forced to abandon the search for altogether, Qoheleth is able to refocus his enquiry. The original programme is transformed into a less ambitious one, captured by the question who knows what is good for a human being while he is alive, during the limited number of days of his absurd living [Qoh 6:11]." However, Frydrych incorrectly assumes that this failure to reach the original goal of inquiry and the subsequent change in focus amounts to an overarching negativity in the books message. See Frydrych, Living under the Sun, 46, 152.

${ }^{138}$ The idea of portion (הלק) as a divinely appointed substitute for in chapter 7, as will the relationship between הrand the "good" that is found in the enjoyment of life.
} 
Qohelet. The motif, thus understood, functions as the necessary foundation upon which (and against which) the wisdom of Qohelet is developed and deployed. Therefore, as Qohelet seeks to determine by wisdom the benefits of wisdom in enabling the wise person to live well in a הבל world, the programmatic question is morphed from "what ?תחיון?" in $1: 3$ to "what good?" in 6:11, thus transforming the original search for solution to the dilemma of to a search for a less ambitious, but divinely apportioned, paradigm for wise living in a הבל world. 


\section{CHAPTER 3}

\section{LIVING "UNDER THE SUN": THE QUESTION OF THEOLOGICAL CONTEXT AND PERSPECTIVE IN THE BOOK OF QOHELET}

In a book saturated with "catch" words and phrases, perhaps no other phrase, aside from those associated with the word הבל, is more characteristic of Qohelet than the descriptive phrase תחת השפוש, translated universally in English versions as "under the sun." The phrase תחת השמים ("under the heavens"; 1:13; 2:3; עלדהארין ("on the earth"; $5: 1$ [Hebrew]; 8:14, 16) are found some 33 times in Qohelet, with "under the sun" having the special distinction of being used in the Hebrew Bible exclusively within the book of Qohelet. ${ }^{2}$ The phrase is distributed quite evenly throughout the book, with its exclusion in chapters 11 and 12 being the only noteworthy exception. ${ }^{3}$ The phrase is utilized with such frequency that it defies simple correlation to unique companion phrases, although the term is almost always used in connection with

\footnotetext{
${ }^{1}$ Exegetical concerns over this phrase relate more to thematic contributions and meaning in the line of argument of the book, not with lexicology or translation. Doug Ingram affirms this by stating, "Although the expression is not used anywhere else in the Hebrew Bible, there seems to be no dispute about its translation, "under the sun." However, תשה השמש is ambiguous because it can be interpreted in more than one way." See Ingram, Ambiguity, 250.

${ }^{2}$ Commentators have expressed divergent views regarding the origin of the phrase "under the sun," including that of Grecian origin, although consensus among modern commentators appeals to Phoenician and Babylonian sources for an ancient Semitic origin. Of special note is the sarcophagus inscription of Eshmun Azor, King of Sidon. Speaking words of warning against potential grave robbers, the inscription reads, "Let him have no root below or fruit above or form among the living under the sun!" Speaking from the context of the grave, the implied meaning of the phrase is to distinguish the world of the living from the world of the dead. See P. Kyle McCarter, Context of Scripture: Monumental Inscriptions from the Biblical World, ed. William W. Hallo (Leiden: Brill, 2000), 182-83. For more on the background of the phrase, see Seow, Ecclesiastes, 104-05 and Longman, Ecclesiastes, 66.

${ }^{3}$ For an excellent chart displaying the phrases' distribution, along with that of its framing terms and variant phrases, see Ingram, Ambiguity, 258.
} 
the common terms עשה ("do, make") and ("work," "toil"), thus demonstrating that the phrase תחת השמש: likely pertains to the realm in which human endeavor is performed. Furthermore, as noted by Ingram, the phrase "seeing the sun" is found elsewhere in Qohelet to refer metaphorically to the experience of living: "in 6:5 the stillborn child is described as not seeing the sun; in 7:11 'those who see the sun' may describe 'the living'; and in $11: 7$ 'seeing the sun' seems to indicate life in contrast to the 'darkening of the sun' in 12:3 which probably pictures approaching death." ${ }^{4}$ Therefore, on the surface, the phrase would appear to indicate "the world people experience while they are alive, the observable world of work and other human activity," and in this regard, present little in the way of exegetical problems or hermeneutical impact. ${ }^{5}$ However, as with most observable peculiarities within the book of Qohelet, the phrase "under the sun" carries more implications than first meets the eye, and does present at least a few exegetical challenges to the careful reader.

Most commentators are in agreement that the phrase "under the sun" functions to describe the scope of Qohelet's experiences and observations. In this sense, the phrase is descriptive, and the main exegetical question relates to the intended breadth of the scope being described, namely, whether the phrase is meant to be restrictive (Qohelet's observations are intentionally restricted to this world alone) or inclusive ("Qohelet's purpose is to underscore the breadth of his observations, claiming that such-and-such is true in the entire world "under the sun," not just a part of it"). ${ }^{6}$ Furthermore, one is faced

\footnotetext{
${ }^{4}$ Ibid, 257.

${ }^{5}$ Ibid.

${ }^{6}$ Fox, A Time to Tear Down, 165. The terms "restrictive" and" inclusive" are unique to Fox, although most commentators can be categorized as affirming one or the other of these two positions. Fox claims that the "restrictive" view is the traditional one, but supports the "inclusive" view.
} 
with the additional exegetical challenge of determining whether or not the distinction between the phrases תחת השמש השמים ("under the sun") and the heavens") were intended to function synonymously as literary variants, or whether the distinction is intentional in describing exegetically significant and distinctively separate dimensions of reality. However, while commentators are certainly correct in assessing the phrase as descriptive, many of them miss another aspect to Qohelet's use of the phrase תמשה השה, the prescriptive function. Prescriptively, Qohelet uses the phrase to affirm the limitations of his inquiry, and thus the phrase functions as a hermeneutical clue for the reader to assess the contextual limitations of Qohelet's "horizontal" perspective. Therefore, the phrase "under the sun," when considered under the umbrella of "motif," takes on a dual role that is both descriptive as to scope and prescriptive as to perspective. ${ }^{7}$

\section{The Scope of Qohelet's Observations-Life "Under the Sun"}

In raising the question of the scope of Qohelet's explorations reflected through the recurring phrase "under the sun," Fox describes two options, the restrictive view and the inclusive view. In the first option, "the purpose of the phrase would be to modestly restrict the application of Qohelet's observations to this world alone, excluding other domains that are beyond human ken." In the second of the two options, "Qohelet's purpose is to underscore the breadth of his observations, claiming that such-and-such is true in the entire world "under the sun," not just a part of it." Another way to distinguish between the two is to describe the restrictive view as suggesting the possibility that "there

\footnotetext{
${ }^{7}$ In examining the phrase and motif "under the sun," one may rightly ask whether the phrase is referring to a place or a perspective. I would suggest that it functions in such a way so as to refer to both.

${ }^{8}$ Fox, A Time to Tear Down, 165.

${ }^{9}$ Ibid.
} 
may be another realm where things are different," the inclusive view simply functions to "emphasize the universality of Qohelet's explorations (this is what life is like everywhere)."11

Commentators are divided over which approach to take, although the majority side with the more traditional, restrictive view. Even so there is some variety of approach even in how the more traditional view is nuanced. For instance, Seow views the limitation as temporal, with the expression "under the sun" "referring to the experiences in the realm of the living-this world of light and life, as opposed to the world of darkness in the netherworld," ${ }^{12}$ whereas Farmer equates the separation as spatial, suggesting that "Qohelet seems to hint that a distinction can be made between what happens here on earth, 'under the sun,' and what happens elsewhere."13 Ogden takes the distinction one step further, so that the activities observed and experienced "under the sun" function as a foil to the eternal dimension of heavenly activity and reward. ${ }^{14}$ Eaton similarly distinguishes between the mundane and the divine, stating that "if our view of life goes no further than 'under the sun' all our endeavors will have an undertone of misery," but

\footnotetext{
${ }^{10}$ Ingram, Ambiguity, 261.
}

${ }^{11}$ Ibid, his emphasis.

${ }^{12}$ Seow, Ecclesiastes, 113. Although Seow's rationale for distinguishing this relationship as temporal is somewhat vague, his classification of the distinction is very explicit. However, in reality, a distinction between this world and the heavenly realm is likely to have spatial as well as temporal aspects, and thus the nuance is as imposed as it is real.

${ }^{13}$ Farmer, Who Knows what is Good?, 150.

${ }^{14}$ Ogden, Qoheleth, 24-29. 
that there also is another realm speaking of the God "who may be approached and worshipped (5:1-7)."15

On the other hand, a few scholars view the description of life "under the sun" as emphasizing the universality of Qohelet's observations. ${ }^{16}$ But rather than see a necessary distinction between a restrictive scope and a universal scope of intention, it may be best to understand the scope of Qohelet's description as incorporating aspects of both views. Thus Frydrych describes the phrase as referring to "the spatial and temporal sphere in which human life happens," effectively incorporating both a temporal and spatial element into his understanding of the descriptive function of the phrase, ${ }^{17}$ and Crenshaw furthermore hints at a synchronization of restrictive and universal approaches by suggesting that "the phrase 'under the sun' reinforces the universal sweep of the thematic statement and its rationale," yet goes on to say that "nothing falls outside the area circumscribed by תחת השמש, except Sheol and heaven," thus suggesting both propositions within a singular treatment of the phrase. ${ }^{18}$ Perhaps the "under the sun" phrase, as with

\footnotetext{
${ }^{15}$ Eaton, Ecclesiastes, 44-45. Although Eaton is similar to others in seeing a restrictive sense in the use of the "under the sun" phrase, his evaluation of the motif extends the application of the restriction to entail not only a foil, but even an implied exhortation to the reader to remove oneself from worldliness, i.e., human activity performed "under the sun."

${ }^{16}$ Fox states that rather than focusing on distinctions, Qohelet is focusing on life "under the sun" and therefore "insists on the broad applicability of his observations to that realm (Fox, $A$ Time to Tear Down, 165)."

${ }^{17}$ Frydrych, Living under the Sun, 45.

${ }^{18}$ Crenshaw, Ecclesiastes, 59, my emphasis. Perhaps Crenshaw is simply being contradictory in his own thinking, but I would choose to see the option of bringing a restrictive sense and a universal sense together as being a possibility in the descriptive scope of Qohelet's use of the term, and thus Crenshaw's statement, even if not intended to convey such multivalency, demonstrates the fluid nature of the phrase.
} 
הבל metaphor, conveys multiple nuances of connotation as enabled by the rather ambiguous capacity of the phrase. ${ }^{19}$

\section{The Distinction between Qohelet's Use of the Phrases "Under the Sun" and "Under the Heavens"}

Aside from matters of intended scope, the key exegetical question pertaining to the "under the sun" phrase entails the use of alternate or variant phrases to nחת השמש, namely, the three occurrences of aשn ("under the heavens"; $1: 13 ; 2: 3 ; 3: 1$ ) and the related על־הארץ ("on the earth"; 5:1 [Hebrew]; 8:14, 16). For those inclined to find distinctions between variant phrases, it is quite easy to speculate as to possible implications between the phrases, especially in distinguishing the contrast between the heavenly realm reflecting God's activity as opposed to the earthly realm of man's activity. On the other hand, scholars recognize the legitimate use of literary variation as a means to enhancing the stylistic qualities of the text, and thus some are more cautious in ascribing exegetical meaning to the distinctions between the related phrases. ${ }^{20}$

The range of opinion regarding this relationship is quite broad. Some commentators view the distinction as a key observation relevant to one's overall approach to the book. ${ }^{21}$ Others, such as Seow, see the distinction as one of nuanced

\footnotetext{
${ }^{19}$ Ingram suggests that the "under the sun" phrase conveys intentional ambiguity, as does the motif and other common terms characteristic of or peculiar to Qohelet. I would rather suggest that ambiguity is a necessary pre-requisite (and possible side-effect) to multivalency and the transition from metaphor to symbol to motif, a tactic employed by Qohelet in numerous situations. See Ingram, Ambiguity, 250-61.

${ }^{20}$ Ingram rightly observes that "if [תהת השמים] were simply an exact synonym, used for literary variation, one might expect it to be used more often and distributed more evenly." See Ingram, Ambiguity, 253.

${ }^{21}$ T. M. Moore goes so far as to largely base his own approach on this key distinction. Regarding his own approach, he states, "This interpretation of the purpose of Ecclesiastes largely hangs on one's understanding of the phrases 'under the heavens' and 'under the sun.' Most - but not all - commentators take these phrases as essentially equivalent, merely different ways of saying the same thing. I see them instead as opposing phrases, used throughout the book to set the discussion either in an earthbound or in a
} 
significance rather than thematic or primary significance, but nevertheless, the distinction is seen as intentional. Thus Seow writes:

Whereas "under the heavens" refers to the universality of experiences everywhere in the world (i.e. it is a spatial designation), "under the sun" refers to the temporal universe of the living (cf. 8:9, where "under the sun" is defined temporally: "a time when..."). In other words, "under the heavens" simply means the cosmos (a term of universality), whereas "under the sun" is a term for "this world" as opposed to the netherworld (see 9:6). ${ }^{22}$

Most commentators, however, see very little difference between the related phrases aside from stylistic variety. Crenshaw states that "there seems to be no difference in meaning between the two expressions," 23 while Ogden and Zogbo write "Under heaven is a variation of the phrase 'under the sun' ... [T]he meaning of the two phrases is identical." ${ }^{24}$ Others describe the two variously as "sister-phrases," variants, or "equivalent" to one another. ${ }^{25}$ Lee describes the two (along with על-האריץ) as "virtually synonymous," while Frydrych simply uses the term "synonymous" to describe the phrases. $^{26}$

Exegetically, if a distinction could be maintained between the contextual use of throughout Qohelet and the three cases in which the writer chooses instead to use תחת השנים, then the curious employment of the two phrases would be answered.

God-oriented frame of reference." See T. M. Moore, Ecclesiastes: Ancient Wisdom when All Else Fails. A New Translation and Interpretive Paraphrase (Downers Grove: Intervarsity, 2001), 11.

22 Seow, Ecclesiastes, 105, 113.

${ }^{23}$ Crenshaw, Ecclesiastes, 60.

${ }^{24}$ Graham S. Ogden and Lynell Zogbo, A Handbook on Ecclesiastes, UBS Handbook Series (New York: United Bible Societies, 1997), 42.

${ }^{25}$ See also Murphy, Ecclesiastes, 7; R. N. Whybray, Ecclesiastes (Sheffield, England: Sheffield Academic Press, 1989), 110; David A. Hubbard, Ecclesiastes, Song of Solomon. The Communicator's Commentary, 15B (Dallas: Word Books, 1991), 46.

${ }^{26}$ See Lee, Vitality, 99 and Frydrych, Living under the Sun, 45. 
However, any nuance that can be attributed to the use of each phrase, whether "under the sun" or "under the heavens," seems to be entirely dependent upon context, and furthermore, varies from context to context. If "under the heavens" were used only in $1: 13$ and $3: 1$, one could argue that the phrase connotes an emphasis on God's activity as opposed to man's activity. ${ }^{27}$ However, the phrase as used in $2: 3$ completely rules out such an assessment, with "under the heavens" clearly referring to mortality and the activity of man: "I searched with my mind how to cheer my body with wine-my mind still guiding me with wisdom-and how to lay hold on folly, until I might see what was good for mortals to do under heaven during the few days of their life (my emphasis)." 28 Therefore, contextually speaking, the case is difficult to maintain for an exegetical distinction between the two phrases.

Thematically, however, one could argue that the "under the sun" motif aids in heightening the distinction between the human and divine realms. Qohelet clearly has interest in examining the relationship between the realms of the human and the divine, and explicitly draws out this distinction on two separate occasions while using the associated phrase על־דארץ ("on the earth"; 5:1 [Hebrew]; 8:14, 16) in context with human/divine relationships. ${ }^{29}$ For instance, we read in 5:2b [Eng]: "God is in heaven, and

\footnotetext{
${ }^{27}$ This is especially true in 3:1 where the argument of $3: 1-17$ emphasizes the distinction between man and the "otherness" of God. Also, 3:17 equates God's act of judgment with a "time for every activity, a time for every deed," thus suggesting, if $3: 1$ and 3:17 form an chiastic inclusio, that God's activity is to be equated with "every activity under heaven (vs. 1)." Qoh 1:13 also suggests that "under the heavens" is descriptive in a unique way of God's activity, with the context equating such activity to a burden that God has laid upon man (compare to $3: 10$ ) and furthermore drawing upon proverbs supporting deterministic theology (1:15; correlate to $3: 14$ and $7: 13-14)$. Such a thematic analysis is compelling, except that the phrase "under the heavens" as used in 2:3 clearly speaks of mortality and the activity of man.

${ }^{28}$ Ingram, Ambiguity, 256.

${ }^{29}$ In 8:14 and 8:16, Qohelet observes injustice and man's labor, both performed "on earth," but then continues by comparing (or contrasting) this to what "God has done" in vs. 17. The exegetical difficulty of making a distinctive point here is exacerbated by Qohelet's use of the phrase "under the sun"
} 
you are on earth, so let your words be few." The basis for this pietistic warning ("God is in heaven/you are on earth") certainly falls in line with the theology of Qohelet, especially as expanded in conjunction with the God/man dichotomy in 3:9-14 and 8:16$17 .^{30}$ Perhaps it is after all appropriate to see man's activity "on the earth," "under the sun," or even "under the heavens" as distinct from the activity of God, but so far as drawing that distinction solely from the way in which the three phrases are used in Qohelet, the evidence seems scant that Qohelet had explicit intentions in designating either phrase as temporal versus eternal, earthly versus heavenly, or connoting man's activity versus God's activity.

\section{The Perspective of Qohelet's Inquiry-The Context of Life Observed "Under the Sun"}

While most scholars recognize the descriptive aspect of the "under the sun" phrase, few have considered the prescriptive hermeneutical implications of the phrase when it is considered as motif. When the phrase and its variant forms are considered as not only describing the scope of his inquiry, but also revealing the perspective of his inquiry, then the phrase takes on a prescriptive function for the reader, a hermeneutical framework through which the reader can view the world through the same lens as did Qohelet. Therefore, a contributing factor to the thesis of this dissertation is that the "under the sun" motif suggests that the observations, reflections, conclusions, and even the pursuit of Qohelet's quest were undertaken from a "horizontal" perspective, and while inspired

in describe man's comprehension of what God "has done." Perhaps Ingram is correct; Qohelet's intentional ambiguity defies black and white exegetical distinctions! See especially Ingram, Ambiguity, 257.

${ }^{30}$ Chapter 5 will examine the relationship between God and man as a central motif, and further connect its association to a proper understanding of the "under the sun" motif. Of 5:2, Seow comments "This is an attempt to correct any misunderstanding about God's immanence and to emphasize the distance between God and humanity (Seow, Ecclesiastes, 198-99)." 
within the canon, were not necessarily revealed by any means other than observation and existential reflection. This "motif" then has serious hermeneutical implications, as well as providing some direction regarding the content and purpose of Qohelet's quest, namely, that his goal was more pragmatic than theological, and his search was not, as commonly thought, for answers to ultimate questions of meaning and purpose in life.

Even while affirming the inspired nature of the text of Qohelet, it must be recognized that Qohelet was a sage in Israel, not a prophet. As a sage, Qohelet's perspective would have naturally been a horizontal one, reflecting upon the world through the lens of wisdom, not speaking forth via the direct revelation of God. ${ }^{31}$ Writing from the "under the sun" perspective, Qohelet's words must be considered within the context from which they came. Although perhaps secondary to the aspect of describing the scope of Qohelet's inquiry, the "under the sun" phrase, repeated throughout the text and taking on the role of motif, nevertheless implies that Qohelet's perspective too is framed within the confines of a horizontal grid, an "under the sun" perspective that limits his assessment of reality. Thus Mills correctly affirms this limitation by stating, "It has to be noted that Qohelet's knowledge and evaluation are always limited to what is under the sun... Here is a specifically human assessment." 32

Other commentators also recognize the limitations of perspective implied through the repeated use of the "under the sun" phrase. Leupold writes:

\footnotetext{
${ }^{31}$ If Qohelet wrote from the perspective of life observed "under the sun," it can also be said that he too assessed life through the perspective of wisdom, or more specifically, the wisdom of ancient Israel. Thus when speaking of perspective and hermeneutics, it is appropriate to speak of Qohelet as also viewing life through the "lens of wisdom." The following chapter will deal with this influence and the hermeneutical implications for the reader in greater detail, also linking this with Qohelet's "under the sun" perspective. 2003), 52 .

${ }^{32}$ Mary E. Mills Reading Ecclesiastes: A Literary and Cultural Exegesis (Aldershot: Ashgate,
} 
It is here that the very important expression "under the sun" must be carefully evaluated, for the correct appreciation of this phrase is one of the major safeguards of the message of the entire book. Not without reason does it occur so often - twenty-five times, that is, the phrase apart from certain equivalents of it... Each time the phrase occurs it is as though the author had said, "Let us for the sake of argument momentarily rule out the higher things." 33

While Leupold incorrectly hints at the assumption of an aspect of carnality in his assessment of Qohelet's limited perspective, he is correct in drawing out the hermeneutical implications inherent in understanding Qohelet's perspective. ${ }^{34}$ As one reads Qohelet, one must keep in mind that Qohelet has not spoken "Thus saith the Lord," but has rather assessed life from the conventions of wisdom. Furthermore, as will be suggested in the following chapter, the wisdom from which Qohelet evaluated life is not in opposition to traditional Hebrew wisdom, but rather, expands and compliments traditional Hebrew wisdom as it evaluates new frontiers.

Noting the perspective from which Qohelet wrote, the reader is compelled to consider three hermeneutical guidelines when reading the text. First, the reader must understand that the text, as reflective of Hebrew wisdom, is inherently pragmatic. While Qohelet touches upon theological issues, his focal point is not an explication of theology; any theology derived from Qohelet is secondary in purpose to his main goal which is essentially pragmatic. ${ }^{35}$ Therefore, it is necessary to avoid reading Qohelet's observations

${ }^{33}$ H. C. Leupold, Exposition of Ecclesiastes (Grand Rapids: Baker Book House, 1952), 42-43.

${ }^{34}$ Qohelet's viewpoint is not based in a backslidden or carnal perspective, but rather, he assesses life from an inherently wise, although human, perspective. The assessment of life and the limitations therein suggested by the "under the sun" perspective are thus framed by God centered wisdom. It is simply incorrect to assume a carnal or worldly perspective through the phrase "under the sun;" nowhere in the text of Qohelet is it ever suggested that Qohelet pursued his quest for 'תרון' from a backslidden, carnal, or worldly state of mind. Rather, the text consistently affirms that Qohelet's mind (if not his actions) was guided by wisdom $(1: 13,16 ; 2: 3,9 ; 10: 9)$, and in the epilogue his words are evaluated as being "upright and true" $(10: 10)$.

${ }^{35}$ Fee and Stuart refer to the theology of the epistles as "task oriented," and thus refer to the theology of Scripture as "task theology." The point in their observation is that the theology of the NT 
and reflections as if theological concerns were at the forefront; he is more often than not simply building his argument around the purpose of teaching how one may live successfully in a הבל world. Second (and this is tied to the first principle), one must remember that Qohelet does not view life from a vertical, heavenly perspective, but rather, from a horizontal, earthly perspective. As Frydrych states, "Consequently, Qohelet limits his inquiry to the here and now, and within this earthly realm, he can find no distinction between humans and other living creatures." ${ }^{\text {" }}$ With an earthly, "under the sun" perspective in mind, it is easy to understand Qohelet's assessment regarding the fate of humans and animals, the righteous and the unrighteous, and the grave. ${ }^{37}$ In his assessment of the grave and the inevitability of death, Qohelet is not speaking from a theologically misinformed perspective, nor is he speaking from a "worldly," "backslidden," or even "misguided" perspective. He is simply speaking from a horizontal perspective through which life is viewed apart from explicit revelation regarding death and the afterlife. ${ }^{38}$

Epistles as not systematically presented, but rather, it is always secondary to the often pragmatic purpose of the author. Their observation is an excellent one, as is their exhortation to caution against proof-texting. If such can be said regarding the NT Epistles, which are largely considered theological, then how much more should caution be exhibited when reading Qohelet, which is decidedly not theological as to its primary function. See Gordon D. Fee and Douglas Stuart, How to Read the Bible for All its Worth, $2^{\text {nd }}$ revised ed. (Grand Rapids: Zondervan, 1993), 76-77.

\footnotetext{
${ }^{36}$ Frydrych, Living under the Sun, 149.

${ }^{37}$ See for example Qoh 3:18-21 and 9:2-5.
}

${ }^{38}$ It is worth noting that Jehovah's Witnesses use Qoh 3:18-21 and 9:2-5 as proof-texts for their theology of annihilationism and soul sleep. The mistake that the Jehovah's Witnesses make is reading theology into the texts where theology was never intended to be taught. If Qohelet was writing with the intention of conveying theological precision from a vertical perspective, the Jehovah's Witnesses would perhaps be correct in their understanding of Qohelet's teaching. However, Qohelet was not teaching annihilationism as theological truth (whether from a misguided or divinely inspired perspective, it does not matter). Rather, he was simply speaking from a horizontal perspective, conveying the idea that in a fallen world all of God's creatures end up in the same common place, the grave, and whether righteous or unrighteous, wise or unwise, man or beast, all come from the dust and to the dust all will return. 
Finally, by way of a third hermeneutical implication, the "under the sun" perspective is suggestive to the reader that Qohelet must be read within its own theological context. ${ }^{39}$ Therefore, not only should Qohelet's words be approached as written from a horizontal perspective, but the text, as inspired, must too be read within the framework of its own theological context. This means that a proper reading of the book will keep Qohelet's place within the canon in mind; the reader should not read New Testament revelation back into the mind of Qohelet, as if Qohelet had the full revelation of God at his disposal. Thus, when Qohelet speaks of judgment, he does so pondering a realm of possibility not yet revealed to the people of God, and although he may hint at the possibility of eschatological judgment, the details of such are outside of the scope of available revelation. ${ }^{40}$ The implications of such are far reaching in assessing Qohelet's theology of death and the afterlife, but at this juncture, the point is simply to consider Qohelet's limitation of available revelation in coming to conclusions regarding his speculation concerning judgment and the afterlife. ${ }^{41}$

In conclusion, the "under the sun" motif functions to limit the scope of Qohelet's inquiry as well as provides a needed framework through which Qohelet's words may be more accurately understood and evaluated. The motif thus functions to provide perspective to the mind of the author, but it also enables the perspective of the reader in approaching the text with a heightened sense of caution. In this way, our exploration of

\footnotetext{
${ }^{39}$ For the term "theological context," see Howard G. Hendricks and William D. Hendricks, Living by the Book (Chicago: Moody Press, 1991), 228-29.

${ }^{40}$ An example of breaching theological context by way of reading NT theology into the mind of Qohelet occurs when readers view references to judgment through the lens of the judgment seat of Christ (2 Cor 5:10) or the Great White Throne judgment (Rev 20:11-15). Qohelet simply could not have had such features in mind when he pondered the possibility of judgment for the righteous and the wicked.

${ }^{41}$ The implications of the "under the sun" perspective and its influence upon Qohelet's view of the afterlife and eschatological judgment will be further examined in chapter 6 and 8 .
} 
the prominent motifs within Qohelet, their inter-dependency, and the meaning of this for the whole, begins with a proper understanding of the perspective from which Qohelet wrote. 


\section{CHAPTER 4}

\section{LOOKING THROUGH THE LENS OF WISDOM: THE ROLE OF WISDOM AND GENRE IN THE BOOK OF QOHELET}

Wisdom takes on a complex role in Qohelet; in one sense, it entails the genre of the book, in another sense, it is the guiding perspective from which Qohelet is led throughout his quest, and finally, it functions as a motif that is explored within the book and in relationship to the other prominent motifs. Qohelet is generally considered a wisdom book, and as such, should be expected to manifest characteristics of Hebrew wisdom literature. However, it is obvious to most that Qohelet does not read in the same manner as the more conventional wisdom of Proverbs. ${ }^{1}$ Qohelet, while containing many examples of proverbial wisdom, is structured in a more complex manner, containing nonproverbial wisdom and a complex line of argument that incorporates elements of tension, skepticism, and exploration into the nature of wisdom itself.

One of the obvious paradoxes facing the interpreter of literature, and in this case, the literature of the Bible, is that an accurate understanding of genre is necessary for the interpretation of the literary text, and yet genre is wholly determined by an accurate understanding of that same text. Thus the genre comes to be understood by the text, and yet the text is truly only understood once the genre is determined. This leads of course to

\footnotetext{
${ }^{1}$ While it is typically assumed that Proverbs sets the standard by which "traditional" wisdom is defined, one should not be too quick to jump to such a conclusion. Seow correctly challenges this assumption, noting that Proverbs represents only a portion of the larger wisdom tradition of ancient Israel, and that sapiential orthodoxy should not be defined by what is found in Proverbs to the exclusion of reflective texts such as Job and Qohelet. Furthermore, it is not certain that Proverbs preceeds Job and Qohelet in chronological development, forming by chronological default a standard by which the other texts are judged. See Seow, Ecclesiastes, 68.
} 
circularity in reasoning, yet it is an inevitable paradox in hermeneutics. ${ }^{2}$ The reader, however, should not be dismayed, for the determination of genre as well as the interpretation of the text comes in stages, not in one illuminating flash. Therefore, this process might better be described as a spiraling process rather than a circular one. As it then pertains to the book of Qohelet, the reader must be sensitive to observe what Qohelet is saying prior to determining genre, and yet reach interpretive conclusions only once genre is understood and applied to the interpretive process. Because "valid interpretation is always governed by a valid inference about genre," it is vitally important to carefully determine the genre of Qohelet in conjunction with the line of argument in Qohelet's thought. ${ }^{3}$ Until this is accomplished, the message of Qohelet will always remain a mystery.

For the reader of Qohelet, literary competence is just as critical as linguistic competence in coming to an accurate understanding of the text. ${ }^{4}$ One may know the Hebrew grammar, syntax, and lexicology, but unless one is accurately sensitive to the genre of the text, the purpose of Qohelet, and the line of argument throughout the text, meaning and clear sense will remain evasive. Thus, in relation to Qohelet and the enterprise of biblical wisdom, one must determine the nature of wisdom in Qohelet as to genre (whether it be conventional wisdom, skeptical wisdom, or a wisdom foil),

\footnotetext{
${ }^{2}$ For discussion on the paradox of determining genre, see E. D. Hirsh, Jr., Validity in Interpretation (New Haven: Yale University Press, 1967), 68-126.

${ }^{3}$ Ibid, 113.

${ }^{4}$ For the distinctions between linguistic competence and literary competence, especially as applied to the hermeneutics of wisdom literature, see John Barton, Reading the Old Testament, 14. It is important to note here that I am not seeking to set these skills against one another, nor do I diminish the importance of linguistic competence in regards to the exegesis of Qohelet. What I am saying is that lexical, grammatical, and syntactical knowledge of Hebrew will not alone be sufficient for the exegesis of Qohelet.
} 
perspective (what Qohelet's view was towards wisdom and the question of whether or not he pursued his quest through the "lens of wisdom"), and motif (Qohelet's teachings regarding the application and theology of wisdom) if one is to arrive at an accurate understanding of the message of Qohelet.

\section{What Kind of Wisdom is This?}

There is no doubt that wisdom is found within the pages of Qohelet. For those who limit wisdom to the more conventional genre of proverbial wisdom, Qohelet does not disappoint. Chapters 4:1-12, 7, 10, and 11:1-6 consist almost entirely of proverbs compiled in much the same manner as those contained within the canonical Book of Proverbs. For those who recognize an expanded element to Hebrew wisdom that incorporates skepticism and theological tension, the entire book of Qohelet drips with wisdom observations, reflections, rationale, internal dialogue, and stated conclusions.

While the wisdom quest should not be confused with its literary by-product, there nevertheless must be some degree of cross-over between the characteristics of wisdom as applied to the society from which it sprung and the texts through which it is represented. Frydrych, in analyzing the essential characteristics of Hebrew wisdom, states that wisdom is "about penetrating beyond that which is observed-it is about understanding the place that a human being has in the world." Thus the key characteristic of wisdom is not necessarily found in literary form or pragmatic function, but in the essential presence of contemplation. To this end Qohelet meets the key criteria (at least according to Frydrych) exceedingly well! Furthermore, in expanding beyond the characteristic of contemplation, Frydrych states that wisdom entails three primary elements: 1) the quest for

\footnotetext{
${ }^{5}$ Frydrych, Living under the Sun, 17.
} 
understanding, 2) the purpose of "getting the most out of life," and 3) practical teachings presented through paradigmatic form. ${ }^{6}$ As will be seen later in our assessment of wisdom as motif in Qohelet, these three elements are clearly present throughout the text of Qohelet.

The opinion of commentators is certainly supportive of approaching Qohelet as a wisdom text. For instance, George Castillino, after surveying the traits of wisdom form, function, and content in Qohelet, concludes that "an assessment of Qohelet can be reached which is in keeping with the spirit of wisdom literature in the OT." James Crenshaw, when alluding to the general approach taken by Qohelet, states that "Qohelet's determination to seek out and explore everything that happens under heaven was achieved through wisdom." ${ }^{8}$ Furthermore, in regard to quest and emphasis, Frydrych states that Qohelet's "less ambitious goal" (6:11 [Hebrew]; as opposed to the primary goal of finding יתרון in 1:3) essentially involves a quest for wisdom-to find "what is good" for a human being while he is alive, and to look for practical ways to "maximize temporary success." ${ }^{99}$ Nevertheless, although the classification of Qohelet as a wisdom text is rarely disputed, there still remains the more difficult question regarding genre and the specific kind of wisdom embraced by Qohelet. To this question commentators are less unified in their opinions.

\footnotetext{
${ }^{6}$ Ibid, $18-23$.

${ }^{7}$ George R. Castellino, "Qohelet and His Wisdom," Catholic Biblical Quarterly 30 (1968): 15-28.

${ }^{8}$ James Crenshaw, Old Testament Wisdom: An Introduction (Atlanta: John Knox Press, 1981), 127.

${ }^{9}$ Frydrych, Living under the Sun, 46. Qoh 6:11a [Heb], as translated by Frydrych, reads, "Who knows what is good for a human being while he is alive, during the limited number of his days of his absurd living ...".
} 
In surveying the nature of wisdom in Qohelet, one discovers that Qohelet's view of wisdom is multidimensional, and yet there is coherence to this multidimensional tension. Michael Fox observes, "Qohelet's ideas on wisdom pull in all directions, yet they do cohere, uncomfortably and unstably." ${ }^{10}$ Qohelet ironically affirms wisdom even as he observes life through the lens of wisdom, and yet his conclusions regarding wisdom are at times quite critical. For Qohelet, wisdom is deficient in securing an understanding of the rationale behind life's events (and if understanding is a primary aim of wisdom, then the deficiency is obvious in Qohelet's line of argument). ${ }^{11}$ Wisdom is also deficient in securing any guarantees regarding the future, or for obtaining any knowledge of the future. ${ }^{12}$ So while Qohelet seeks to find understanding and security through wisdom, he comes to realize that wisdom is ultimately unable to provide the understanding and security for which he seeks. The irony behind all of this is that it is only through wisdom that one is able to discover the deficiencies of wisdom.

In addition to the above stated deficiencies, Qohelet also observes that wisdom is vulnerable to "folly and fickle fortune." The paradox that wisdom is profitable and strong, yet vulnerable and insecure can be seen in the reflections of 9:18 and 10:1. Equally paradoxical and certainly unfortunate is the scenario in which an intelligent man's wisdom gains him great wealth $(2: 19 b)$ and yet all this is lost to some random

\footnotetext{
${ }^{10}$ Fox, A Time to Tear Down, 87.

${ }^{11}$ On Qohelet's quest for understanding, see Qoh 7:24-26; 8:17. On the deficiency of wisdom (or contemplation) as a means to deliver, see Qoh $3: 11 ; 7: 14 \mathrm{~b} ; 8: 16-17$.

${ }^{12}$ These two "kinds" of wisdom, or perhaps better, "goals" of wisdom, both correspond to the two major aspects of the aspect of transitoriness or brevity, and the aspect of enigma, or "absurdity."

Regarding wisdom's inability to provide knowledge of the future (or a guarantee), see Qoh 6:12; 7:14; 8:7; 9:12; 10:14. See also Michael Fox, Qohelet and His Contradictions, (Sheffield: Almond Press, 1989), 10106.

${ }^{13}$ See Qoh 5:13; 9:11-12.
} 
misfortune (5:13). One might say that stupidity is more powerful than wisdom, yet time and chance is more powerful than both! ${ }^{14}$

The tension between the applied value of wisdom and the grievous vulnerabilities to which wisdom is subject lies at the heart of many of Qohelet's apparently contradictory statements regarding wisdom. Although Qohelet observes that wisdom has the power to preserve the life of its possessor $(7: 12)$, its achievements are nevertheless overwhelmed by the inevitability of death (2:16). Death is the great leveler of things, and although wisdom may deliver for a time, it ultimately fails to deliver its possessor from the finality of death, for, "like the fool, the wise man too must die! (2:16)" This tension too is paradoxical, for "if the fate of the fool will overtake me also, what then do I gain by being wise? (2:15)"15 Perhaps the most troubling paradox uncovered by Qohelet pertains to the hurt that much wisdom brings $(1: 18)$. Thus we begin to see the difficulty of approaching the wisdom of Qohelet in a one dimensional way; Qohelet's observations about life resist this one dimensional approach, but rather they demand a more complex, multidimensional feel for unraveling the truly honest observations and conclusions about wisdom, even as these observations and conclusions have been reached through wisdom.

It is easy to confuse paradoxical tension in Qohelet with contradiction, skepticism with pessimism, and realism with fatalism. Such tension as observed within Qohelet is inherent within the wisdom employed throughout the book as much as it is observed in Qohelet's statements about wisdom itself. Wisdom as such is then subject to the nature of reality as experienced in a הבל world, a world full of paradox, indeed, full of absurdity

\footnotetext{
${ }^{14}$ One of the key elements in Qohelet's theology of wisdom is that wisdom only has relative value; it is always subject to chance! See Frydrych, Living under the Sun, 191-92.

${ }^{15}$ On the relationship between death and wisdom, and the relative value of wisdom in light of the inevitability of death, see also Koh, Royal Autobiography, 196-98.
} 
and best described by Qohelet the wise man as הבל. The wisdom of Qohelet then does not seek to absolve tension and paradox, but rather, it teaches the very limitations of man in a fallen world. Biblical wisdom does not give man control, but to the contrary, Qohelet teaches that "real biblical wisdom is founded on the honest acknowledgement that this world's course is enigmatic, that most, if not all, of what happens is quite inexplicable, incomprehensible to us, and quite out of our control.",16

The issue of contradiction has long been observed by readers of Qohelet, and has been seen by many as reason to doubt its status within the canon. ${ }^{17}$ However, it is the contention of this author that Qohelet's use of contradiction is intentional and "deliberately dialectical," 18 and therefore, may be better thought of as a display of "wisdom tension" rather than illogical contradiction. In regards to wisdom, this means that the wisdom of Qohelet can at times be seen to be very similar to the experience of Job, where "tradition tells us that 'it will be well with those who fear God' and 'it will not be well with the wicked' $(8: 12-13)$, but experience tells us that 'on earth, there are righteous people who are treated according to the conduct of the wicked, and there are

\footnotetext{
${ }^{16}$ Jeffrey Meyers, A Table in the Mist: Ecclesiastes through New Eyes (Monroe, Louisiana: Athanasius Press, 2006), 16-17. In direct reference to the creation account, Meyers too notes the relationship between the pursuit of knowledge in being a catalyst to the fall and the deficiency of wisdom and knowledge as a subsequent result of the fall. The irony is not to be missed! See Meyers, A Table in the Mist, 32-35.

${ }^{17}$ Fox observes that the issue among early rabbis was not so much whether the book was inspired or canonical, but rather, what the function of such inspired literature ought to be within the canon and within the religious life of Israel. "The question was whether these books were suitable and 'safe' for general use." See Fox, $A$ Time to Tear Down, 1. Taking a more skeptical view of canonical acceptance on the part of the Jewish community, Katharine Dell proposes that conformity to traditional wisdom, especially in the redactional work of the epilogist, was necessary for canonical acceptance to take place for the book of Qohelet. See Katharine J. Dell, "Ecclesiastes as Wisdom: Consulting Early Interpreters," VT 44 no 3 (1994): 301-29.

${ }^{18}$ Kathleen Farmer, et al., The Hebrew Bible Today: An Introduction to Critical Issues (Louisville: Westminster John Knox Press, 1998), 140.
} 
wicked people who are treated according to the conduct of the righteous' $(8: 14) . " 19$ This "Yes, but ..." style of discussion is used to show the non-absolute nature of many of the propositions that traditional teachings had held to be absolute. ${ }^{20}$ Thus, in agreement with Fox, we contend that, pertaining to the wisdom motif as well as to the book in general, the "contradictions in the book of Qohelet are real and intended. We must interpret them, not eliminate them."21 For the reader to truly enter into the wisdom of Qohelet, he must learn to embrace the tension of the text, rather than seek to explain it, resolve it, or systematize it. Only when this tension is understood in conjunction with the goal, purpose, and line of argument of Qohelet's quest, can the reader be prepared to understand and appropriate the benefits of so called "skeptical" wisdom.

The question yet remains regarding how one might best define Qohelet's wisdom. To note the variety of approaches, Norman Whybray asks the question, "Is Qohelet best described as a pessimist, a realist, or in spite of appearances, an optimist?"22 James Crenshaw helps to answer this question by distinguishing between skepticism, pessimism, and cynicism. For Crenshaw, the skeptic is one who doubts that which is conventionally believed, but does so only within the context of the foundation of a "profound faith." ${ }^{, 23}$ In this sense, skepticism is an honest way of reflecting upon doubt all

${ }^{19}$ Ibid, $140-41$.

${ }^{20}$ Ibid, 140. In an interesting adjustment to the more general "zwar/aber" approach to contradictions in Qohelet, Frydrych suggests that the wisdom paradigm of Qohelet incorporates and expansion of the unqualified, proverbial "better" with the qualified "better, but ..." wisdom of Qohelet. See Frydrych, Living under the Sun, 49-50.

${ }^{21}$ Fox, A Time to Tear Down, 3.

${ }^{22}$ R. N. Whybray, Wisdom: The Collected Articles of Norman Whybray (Burlington, VT: Ashgate), 11.

${ }^{23}$ Crenshaw, An Introduction, 190. 
the while retaining faith. One might go so far as to say that "skepticism" is the only honest approach to real faith! Pessimism, on the other hand, allows doubt to achieve the upper hand. Therefore, the pessimist is overtaken by the oppressive reality of doubt and succumbs to its weight. ${ }^{24}$ Crenshaw understands cynicism to go one step further; "by their disdain for creaturely comforts and sensual pleasure they show contempt for everything life has to offer." ${ }^{25}$ Within the framework of this narrow definition, Crenshaw rightly attributes a kind of skepticism to Qohelet, noting the positive conclusions indicative of a faith that has remained in spite of the many inconsistencies to his faith that Qohelet has wrestled with. ${ }^{26}$

Others, however, have viewed the wisdom of Qohelet from a less positive standpoint. William Anderson concludes in his investigation on the topic, "Therefore, Qohelet may be viewed as a skeptic turned pessimist but not a cynic. The fact that Qohelet was a pessimist-and this basic view and attitude toward life are manifest in his book-means that the genre of his book should be recognized as pessimistic literature."27 The distinction between viewing the wisdom of Qohelet as either skepticism or pessimism is quite profound. One should note the implications that this choice has hermeneutically. If Anderson is correct, then Qohelet does not provide an essential wisdom paradigm for living in light of הבל. Although there may be pessimistic tones

${ }^{24}$ William Anderson, in taking the view that Qohelet is thoroughly pessimistic in its outlook towards wisdom, has gone so far as to relegate all optimistic statements regarding the relative value of wisdom, along with other optimistic injunctions (such as the call to enjoy life), as "emotional outbursts of psychological relief." See William H. U. Anderson, Qoheleth and its Pessimistic Theology: Hermeneutical Struggles in Wisdom Literature (Lewiston, NY: Mellen Press, 1997), 95.

${ }^{25}$ Crenshaw, An Introduction to Wisdom, 191.

${ }^{26}$ Ibid, 190-96.

${ }^{27}$ Anderson, Pessimistic Theology, 89-94. Anderson distinguishes between Qohelet's "philosophical skepticism" and "attitudinal pessimism," but nevertheless concludes that the message of the book, including the theology of wisdom espoused by the book, is essentially pessimistic in nature. 
within Qohelet, these must be balanced with the positive conclusions and statements found throughout the book. Therefore, an understanding of Qohelet as a "realist," one who weighs his experiences with his theology, and through skeptical wisdom, discovers how the wise will truly react to the world in which we live, will enable one to arrive at a balanced approach to the wisdom of Qohelet. This is the hermeneutical key to understanding so called "skeptical" wisdom, or the wisdom of the supreme realist-one must learn to appreciate the tension within the text, a tension that is indicative of the internal struggles of a wise skeptic (or realist). Hermeneutically, any one statement in Qohelet must always be understood in relation to its place in the web of interrelated motifs discovered in the text. These motifs, and their apparently contradictory nature, are often representative of the struggles within the wise mind of the inspired skeptic. Qohelet would even imply that the wise mind brings grief and sorrow-perhaps it is the glory of the wise to ponder the mysteries of the universe, even if wisdom does not bring all of the answers (1:17-18). Could it be that half the battle in becoming wise is learning to ask the right questions? In this sense, could it be that skeptical wisdom is reflective of one who has learned to ponder the universe by asking the right questions, even if he never finds the answers?

The tension evident in Qohelet's approach to wisdom is not representative of a "crisis" in wisdom or conflict between "traditional" wisdom and "skeptical" wisdom, ${ }^{28}$ but rather, it reflects an expansion "upon traditional wisdom through the notion that one

\footnotetext{
${ }^{28}$ Frydrych argues that the "crisis theory" does not account for the textual data, a point with which I concur. However, I disagree with Frydrych's conclusions regarding the diachronic development of canonical wisdom theology as representative of changing social structures. Rather, I prefer a synchronic approach to canonical wisdom theology so far as comparisons between the books of the wisdom corpus is concerned (the wisdom of Qohelet expands and heightens the wisdom of Proverbs as to content, but not necessarily in regards to a chronological social and theological climate within ancient Israel). See Frydrych, Living under the Sun, 4.
} 
may use independent intellect to discover new wisdom," to bring together the "learned knowledge (1:16)" of tradition with the empirical contemplation of realism. ${ }^{29}$ Thus, Qohelet "appropriates and extends" ${ }^{\text {"30 }}$ the limits of wisdom to reach new heights. Indeed, as wisdom literature, Qohelet represents the apex of canonical wisdom. ${ }^{31}$

\section{Looking through the Lens of Wisdom}

In spite of the opinion of a few scholars that Qohelet holds to a pessimistic view of wisdom, ${ }^{32}$ the overwhelming evidence from within the text suggests that Qoheleth never rejects wisdom nor does he ever commend folly as an option."${ }^{, 33}$ The critical testing of wisdom and the revelation of its deficiencies should not be confused with an outright rejection of wisdom. Indeed, modern consensus affirms that "Qoheleth's attitude towards wisdom is essentially a positive one. ${ }^{34}$ Nearly a half-century ago, von Rad recognized that "recent writings have shown that its [Qohelet's] affinities with the thought of traditional wisdom are in fact much greater than was once supposed, ${ }^{, 35}$ and furthermore, current trends in scholarship are recognizing that Qohelet is not turning his back on wisdom, but rather, is calling his followers to return to wisdom's chief goal, the "art of

\footnotetext{
${ }^{29}$ Fox, A Time to Tear Down, 76.

${ }^{30}$ Frydrych, Living under the Sun, 204.

${ }^{31}$ Meyer, A Table in the Mist, 21.

${ }^{32}$ Anderson, Pessimistic Theology, 194.
}

${ }^{33}$ Koh, Royal Autobiography, 196. Note also E. Levine who writes, "Despite his repeated caveat lector that available knowledge is limited, Qohelet is the Bible's most militant advocate of wisdom and most strident critic of folly." See E. Levine, "Qohelet's Fool: A Composite Portrait," in On Humour and the Comic in the Hebrew Bible, ed. Y. T. Radday (Sheffield: Almond Press, 1990), 278-79.

${ }^{34}$ Koh, Royal Autobiography, 200.

${ }^{35}$ Gerhard von Rad, Old Testament Theology, vol. 1, trans. D. M. G. Stalker, (Harper Collins: San Francisco, 1962), 455. 
steering" life. ${ }^{36}$ Thus Qohelet's aim in pursuing his quest while looking through the "lens of wisdom" is quite in line with the pragmatic nature of wisdom itself, that is, in answering the question of "how to make the most of life." "37

As reported by Qohelet, the existential investigation of life and the literary quest for "started from wisdom (1:16), aimed at wisdom $(1: 17 ; 7: 23 \mathrm{~b})$, and proceeded by wisdom (1:13)." ${ }^{38}$ In the first two chapters of the book, Qohelet, in the first person, proclaims four times that the quest he is pursuing will be guided by and through wisdom $(1: 13,17 ; 2: 3$, 9). Qohelet proclaims from the outset of his quest for 9 (1:3) that he will devote himself to explore "by wisdom" all that is done under heaven $(1: 13){ }^{39}$ This is a clear affirmation that the observations and the evaluations found within the book are filtered through the "lens of wisdom." 40 Whatever this wisdom entails, it is undeniable that Qohelet is guided by a kind of wisdom throughout his journey. The only counter to such

\footnotetext{
${ }^{36}$ Johnston rightly redirects the goal of wisdom away from "the task of mastering life" (as per von $\mathrm{Rad}$ ) to the "art of steering life." Indeed, if this is the goal of wisdom, then Qohelet succeeds with his probabilistic approach to life's contingencies and the art of wise risk taking. Thus, Qohelet does not reject wisdom, but rather, redirects it. See Robert K. Johnston, "Confessions of a Workaholic: A Reappraisal of Qoheleth." Catholic Biblical Quarterly 38 (1976): 27-28.

${ }^{37}$ Frydrych is correct in stating that Qohelet's aim is "very much the same as that of the proverbial sages; they are all interested in the question of how to make the most of life." The pragmatic nature of Hebrew wisdom is clearly evident in the wisdom of Qohelet even as it is in the wisdom of Proverbs. This should not be ignored as one assesses the perspective and purpose from which and to which Qohelet wrote. See Frydrych, Living under the Sun, 189.

${ }^{38}$ Fox, $A$ Time to Tear Down, 77.

${ }^{39}$ In spite of the fact that Qohelet augments his quest to the reorientation of a "less ambitious goal" in 6:11, he nevertheless continues to evaluate options for successful living in the spirit of wisdom. Thus, even if wisdom was insufficient for the discovery of ultimate advantage (יחר), nevertheless, wisdom performs at its best in the pursuit of Qohelet's less ambitious goal of finding advantage for temporary success in a fallen world. See Frydrych, Living under the Sun, 46.

${ }^{40}$ The phrase "through the lens of wisdom" is original to the author of this paper. This phrase is to be understood as the guiding perspective through which Qohelet evaluates his observations and experiences as he seeks for חתרון and ponders how the wise man might best live in a
} 
an assessment would be to claim that Qohelet was misguided in his own evaluation of himself or to understand that the quest began with the right perspective, but fell from the heights of wisdom to the depths of folly. However, the text itself never indicates such a fall from the wisdom perspective, and the third person affirmation in the epilogue (12:910) would seem to suggest that the whole journey was conducted by wisdom and evaluated through the "lens of wisdom."

Not only is Qohelet determined to follow the guidance of wisdom as he pursues יתרון, but he is also qualified for the task at hand. He claims to have "grown and increased in wisdom more than anyone who has ruled over Jerusalem before me (1:16)." This claim finds a literary parallel in 2:7 and 2:9, where Qohelet claims to have "owned more herds and flocks than anyone in Jerusalem before me," and to have "become greater by far than anyone in Jerusalem before me." These claims amount to a convincing argument that Qohelet is uniquely qualified for the task at hand (he is wise, wealthy, and powerful). If יתרון can be found in any material thing, or any pleasure experienced by man, Qohelet has the means by which to experience and arrive at יתרון. If only a wise man can discern תרין within and amongst these experiences, then Qohelet is the most qualified to make such discerning observations. In either case, Qohelet's alleged hedonism experienced in the course of his life (2:1-11) is not antithetical to wisdom, but rather in accordance with wisdom. Qoh 2:3 brings this to the forefront with a very paradoxical claim; Qohelet cheers himself with wine, and embraces folly (to see if either of these bring a solution to the dilemma of 7 ), but in doing so he claims that his mind is still guiding him through wisdom. Qohelet's quest is an experiential one, and to adequately explore the potential solution to the dilemma of הבל, he must leave no realm of experience untouched. 
Furthermore, these experiential pursuits are only a part of a larger quest (pleasure is not an end to itself, nor does hedonistic pleasure constitute a motif in Qohelet), one that is performed under the guidance of wisdom. Therefore, Qohelet can rightly say that he has embraced folly all the while discerning and evaluating his experiences through the control of wisdom.

Qohelet 2:9-11 concludes Qohelet's opening remarks regarding the position that wisdom has in controlling Qohelet's quest for יתרון. As with his experiences with drink and folly, so in his experiences with pleasure and wealth Qohelet continues to be controlled by the dictates of wisdom. Notice that in setting the stage and reporting the facts of his quest, Qohelet four times affirms that his experiences and observations are being evaluated by wisdom and through wisdom. ${ }^{41}$ Nowhere does Qohelet ever deny this fact. Those who presume that Qohelet was a paganistic hedonist, or even a backslidden idolater, do so at the expense of the clear statements of the text. At the very least, if Qohelet practices sin, he does so as a "wise sinner." However, nowhere does he pursue that which is clearly judged as sinful. Yes, he had everything a man could ever hope to have, and in this sense, he could truly say that wealth, pleasure, and the pursuits of folly did not provide תמון, a solution to the dilemma of

\section{Wisdom as Motif in Qohelet}

Although Qohelet pursues his quest through the lens of wisdom, nevertheless he consistently confirms the limitations of wisdom in regards to solving the dilemma of

\footnotetext{
${ }^{41}$ If one includes the affirmation of his qualification in wisdom from $1: 16$, then there are five statements affirming the role of wisdom in Qohelet's quest $(1: 13,16,17 ; 2: 3,9)$.
} 
The limitations of wisdom are often couched in the form of proverbial wisdom, and such statements are found even in the beginning of the book, even within the midst of Qohelet's remarks concerning his own "increase" in wisdom. Statements such as that found in 1:18a, "For with much wisdom comes much sorrow" demonstrate from the outset the limitations of wisdom. Wisdom will certainly enlighten you to the dilemma of הבל , הבל , but it will fall short in providing a solution to the dilemma words, there is no יתרון in wisdom, at least so far as the dilemma of הבל is concerned, and this fact too adds to the vexation experienced by Qohelet. These thoughts are expanded in 2:12-16; in verses 12 through 16, Qohelet strikes a balance between the value and the limitations of wisdom. ${ }^{43}$ Wisdom will not gain anything new under the sun $(2: 12)$, nor will it result in any lasting legacy $(2: 16) .{ }^{44}$ The wise man like the fool too must die; therefore wisdom does not provide a solution to the inevitability of death. ${ }^{45}$ Nevertheless, wisdom is not without value, however temporal it may be. ${ }^{46} \mathrm{~W}$ isdom provides

\footnotetext{
${ }^{42}$ The limitations of wisdom are relative to the quest for So far as wisdom itself is concerned,
} Qohelet may have had wisdom, yet the kind of wisdom that provided him with satisfaction in reaching his primary goal was indeed far out of reach. The vexation of all things הבל qualified to limit the effectiveness of wisdom; in the end, Qohelet feels that he failed to ever gain wisdom that satisfied the task at hand (7:2324). One might say that "wisdom of the sort Qohelet yearned for is beyond man's reach (Fox, A Time to Tear Down, 88)."

${ }^{43}$ In 1:17 and 2:12 Qohelet applies himself to the understanding of wisdom (in reference to its value as a solution to the dilemma of הבל ). Of course, to understand wisdom one must also understand it in relationship to madness and folly, the foils to wisdom.

${ }^{44}$ The idea of a lasting legacy seems to be in accordance with Qohelet's concept of alluded to in $1: 11 ; 8: 10 ; 9: 5,15$.

${ }^{45}$ The limitations of wisdom are all related to the fact that wisdom is at once thwarted by God, death, and the scruples of all that הבל entails. In the end of Qohelet's exploration into the value of wisdom in the light of death's undiscerning nature, "Qohelet recommends that the wisest action is to make the most of life in the light of the limits that death sets to human aspirations (Koh, Royal Autobiography, 198).

${ }^{46}$ Even apart from the immediate context of chapter two, Qohelet undoubtedly sees wisdom as advantageous over folly. Through wisdom, one can earn wealth $(2: 19 b, 21 a)$, remain safe in times of mortal danger (7:12), have advantage over physical might (9:13-18), and in general, do things better than without wisdom (10:2). The wise man is better able to make decisions $(8: 5)$, his face is cheerful $(8: 1 \mathrm{~b})$, his speech 
discernment throughout the years that God has given a man under the sun, and therefore it is better to live these few short years guided by wisdom rather than by folly $(2: 13-14) .{ }^{47}$

The enigmatic value of wisdom is clearly seen in 2:21-26. Wisdom is seen throughout this passage as a positive thing, so much so that it is something given by God to men who "please him" (2:26). Nevertheless, wisdom really has its greatest value not in providing מרון, or any hint of a lasting legacy, but rather, in providing temporal advancement in the temporal life under the sun. ${ }^{48}$ The point of contrast throughout this passage is interesting, because in verse 21 a man may work with wisdom, and yet find that he must leave all his achievements to someone who has not worked for it. So wisdom profits a man greatly, and he is blessed by God in conjunction with wisdom, yet wisdom still cannot provide the legacy or the תרון for which Qohelet seeks. ${ }^{49}$

In chapter 4, Qohelet demonstrates the pragmatic value of wisdom through various proverbs and example stories. Although there are no explicit references to wisdom in this section, this section is largely composed of a series of proverbs reflecting upon the practicalities of contentment and what brings success in this life. Such

is discerning (10:12) and effective (9:17). The mind of the wise is his blessing (as opposed to the mind of the fool being his downfall; $10: 1)$, and although with knowledge comes sorrow $(1: 18 ; 7: 4)$, this too is seen as an advantage over the ignorance of folly $(7: 2 ; 9: 5)$. See Fox, A Time to Tear Down, 92-93.

${ }^{47}$ It is in this sense that wisdom as viewed by Qohelet falls much in line with what many modern scholars say about Hebrew wisdom in general; that Hebrew wisdom is profitable for gain in the present world, but has little impact on personal eschatology. Although some may challenge this limitation to wisdom via New Testament soteriology, nevertheless the observed focus of Hebrew wisdom tends to be upon the practical and pragmatic affairs of life. As Frydrych states, "For Qoheleth, the value of knowledge is explicitly located in its practical benefits (Frydrych, Living under the Sun, 47)."

${ }^{48}$ The emphasis on the temporal is compounded by Qohelet's redirected, "less ambitious" goal as stated in 6:11; to "know what is good for a human being while he is alive, during the limited number of days of his absurd living" (italics and translation that of Frydrych, Living under the Sun, 46).

${ }^{49}$ It is especially striking that God is responsible both for providing man with wisdom so that he might prosper, and yet God is also responsible for the lack of lasting value to that which was achieved through wisdom. For Qohelet, observations in this vein provide much of the impetus for his statements regarding all that is "hevel." 
observations are characteristic of Hebrew wisdom, and add to the cumulative evidence that Qohelet is working within the framework of the wisdom tradition. Many of the proverbs contained in 4:1-16 and 7:1-8 are "better than" sayings, calling upon the reader to discern what the point of comparison might be between the two elements within the proverb. ${ }^{50}$ Like most proverbial forms, the "better than" sayings are practical sayings that cause a reader to ponder the point of application through somewhat obscure statements. In Qohelet, these statements should always be viewed within the greater scope of Qohelet's view of life: knowing the brevity of life and the inevitability of death, what might a "better" way to live be? Furthermore, knowing the absurdity of life under the sovereign control of God, how might the wise man live in a life without guarantee $?^{51}$ Beyond the "better than" sayings, the proverbial wisdom of chapter seven continues to ponder the value and the limitations of wisdom in a הבל world. For instance, in 7:11-12 the value of wisdom is again seen; it is good and beneficial so far as this life under the sun is concerned. ${ }^{52}$ Nevertheless, in spite of the temporal advantage gained by wisdom, there are no guarantees of a future payoff due to the enigmatic nature of future

\footnotetext{
${ }^{50}$ For a brief introduction to "better than" sayings, see Ted A. Hildebrandt, Cracking Old Testament Codes: A Guide to Interpreting the Literary Genres of the Old Testament, ed. D. Brent Sandy and Ronald L. Geise, Jr. (Nashville: Broadman and Holman, 1995), 242.

${ }^{51}$ Frydrych states, "Qohelet's paradigm is not on forecasting what will happen, but about making the most of the events that one cannot predict or control . . (Frydrych, Living under the Sun, 50)." In this sense, the "better than" statements (or the "better, but . . ." contingencies") emphasize practical advantage in a הבל wherld. While the wisdom of Qohelet's proverbs may not provide in the sense of the programmatic question (1:3), the nature of Qohelet's wisdom clearly indicates that wisdom does give practical advantage within the framework of Qohelet's worldview.

${ }^{52}$ Ecclesiastes 7:11-12 provides an example of another subgenre among proverbial wisdom forms-the comparative saying. See Hildebrandt, Cracking Old Testament Codes, 243.
} 
engagement. ${ }^{53}$ Thus, by way of implication, the limitations of wisdom are indicated in the following verses $(7: 13-14)$; even the wise man is subject to the sovereign determination of God, and can thus do little to ultimately control or to know his future.

The world that Qohelet observes is far too enigmatic and absurd to guarantee success as a result of one's own moral and pragmatic decision-making. Qohelet has observed the "righteous man perishing in his righteousness," and "the wicked man living long in his wickedness (7:15)." In context, Qohelet is concerned with the exceptions he has observed to the doctrine of divine retribution, and thus in the proverb which follows (7:16-18), Qohelet provides a tempered approach to living in light of such absurd circumstances. ${ }^{54}$ The point of the proverb is to not to teach a "golden mean" that guards against self-righteous legalism and the dangers of overly wicked behavior. Rather, Qohelet's admonishment against overrighteousness is a warning to not rely upon one's righteousness as a security, and his admonishment against wickedness is a warning to not ignore the possibility of retribution in spite of the exceptions observed. ${ }^{55}$

Exegetically, such an understanding of Qoh 7:15-18 depends upon a semantic variation on the meaning of the verb שמכ (the $2 \mathrm{~ms}$ hithpael form found at the close of v. 16. While שמפ is typically glossed as "to be desolate," "horrified," or "made

\footnotetext{
${ }^{53}$ Peter Enns calls this lack of guaranteed payoff the ultimate source of frustration for Qohelet.
} See Peter Enns, Inspiration and Incarnation: Evangelicals and the Problem of the Old Testament (Grand Rapids: Baker Academic, 2005), 79.

\footnotetext{
${ }^{54}$ The observation of Qohelet in 7:15 is exactly the reason why Qohelet views life as absurd. In 8:14, a very similar observation is deemed as thus providing the basis for at least one aspect of the motif. See Fox, A Time to Tear Down, for the use of "absurd" to define הבל, 30-33.

${ }^{55}$ Fox states that "Qohelet's critique of wisdom is not an attack on its foundations so much as an expression of disappointment and a warning not to expect too much of it." Such an assessment falls right in line with Qohelet's "wisdom solution" in 7:15-18; true wisdom recognizes the limitations of wisdom as much as it uses wisdom as an advantage. See Fox, $A$ Time to Tear Down, 92.
} 
desolate," by extension the word is often descriptive of the revulsion or astonishment that comes as a result of divine judgment. ${ }^{56}$ Thus, the term can be glossed as "to be appalled, astounded, or awestruck." Such an option is plausible in this context; for the one who places his security for future prosperity in his righteous living, he may find himself "appalled" when he falls into the snare of suffering and discovers that his righteousness was no guarantee against calamity. Thus, in a sense, his false hope in the security of righteousness is destroyed, and as a result, he finds himself "astonished" by what has occurred.

Furthermore, in acknowledging the limitations of wisdom in securing one's future, Qohelet teaches that one should not use this reality as an excuse to $\sin (\mathrm{v} .17)$. The wise man will not trust in his righteousness as a guarantee (v. 16), but neither will he embrace wickedness while placing his bets against retribution (v. 17). This balance and realism is a trademark of Qohelet's wisdom, and must be understood if one is to properly understand the tension seen in this text. ${ }^{57}$

In assessing Qohelet's theology of wisdom, perhaps no clearer statement on the value or limitations of wisdom is found than that in 8:16-17. Here Qohelet expounds upon the limitations of wisdom, especially in light of the sovereign hand of God. So far as the dilemma of is concerned, God has limited wisdom so that man can do nothing

${ }^{56}$ Tyler F. Williams, NIDOTTE, Willem A. VanGemeren, gen. ed., (vol. 4 Grand Rapids: Zondervan, 1997) 167-71. Williams cites 28 cases where the verb שמם denotes the sense of revulsion or astonishment when confronted with the results of divine judgment, including Lev 26:32; Job 17:8; Jer 50:13; and Dan 8:27.

${ }^{57}$ For an overview of 7:15-18 from various exegetical perspectives, see Wayne A. Brindle, "Righteousness and Wickedness in Ecclesiastes 7:15-18," AUSS 23 (1985): 243-57. 
to find הבל a world. ${ }^{58}$ In a sense, 8:16-17 may actually be an admission to failure; Qohelet has found that nothing, including wisdom, has proven to provide any יתרון in a הבל world. Perhaps Qohelet has himself in mind when he claims that even a wise man cannot comprehend, and thus, in spite of the many benefits of wisdom, it ultimately falls short of supplying that which Qohelet seeks. Nevertheless, it is only because of wisdom that Qohelet has come to recognize this limitation, and in turn, how to respond. ${ }^{59}$

While the enjoy life motif stands on its own apart from the wisdom motif in Qohelet, the two are nevertheless inter-dependant. Qohelet teaches that "true wisdom encompasses the sense to enjoy in the present that which can be enjoyed," $" 60$ a paradigmatic approach to life that considers with sobriety the inevitability of death, the uncertainty of the future, and the value of the present as a gift from God. Thus, in 9:7-10, Qohelet's "enjoy life" imperative should not be read apart from the wisdom motif which surrounds it; indeed, the wisdom of Qohelet throughout is "characterized by the enjoyment of life and seizing the day (9:10)."61 Of course, in the wisdom of Qohelet, the enjoyment of life is not characterized by folly and vain pleasure, but rather, with an

\footnotetext{
${ }^{58}$ Such a line of thought is pervasive in Qohelet, but perhaps nowhere is it quite as clear as in 3:914. The deficiency of wisdom ultimately relates back to the fall, the curse, and the limitations imposed upon man by God. If man could not have access to the "tree of knowledge" prior to the fall, then wisdom certainly would not be sufficient as a source of knowledge after the fall. God himself has limited man and his wisdom so far as eternal perspective is concerned. The purpose of such is succinctly put in Qoh 3:14c, "God does it so that men will revere him." On the relationship of the limitations of wisdom to the tree of the knowledge of good and evil, see Meyer, A Table in the Mist, 30-34. On the limitations of wisdom imposed by God, proactively installed as "God places barriers to human insight," see Fox, A Time to Tear Down, 87-88.

${ }^{59}$ It is the contention of the author that the primary conclusion in the book of Qohelet relates back to this failure. If wisdom does not solve the dilemma of then can it at least teach a wise man how to live within a world that can only be described as הבה?

${ }^{60}$ Frydrych, Living under the Sun, 74.

${ }^{61}$ Ibid, 191-92.
} 
approach to life that understands "the fullest appreciation of present experience." "T2 Thus, Qohelet's concern is not for the wise man to find pleasure more valuable than work, but rather, that the wise man consider the present as the best opportunity to accomplish anything, whether it be work or pleasure. Indeed, "Qoheleth is not just concerned that one seizes the opportunity to enjoy oneself, but more generally, that one seizes the moment for anything one may be doing." 63

Qohelet 9:11 through 11:6 continues in presenting select proverbs either reflecting upon the "absurdity" of life, or proposing advice on how to advance in a world that is ultimately unsure. This uncertainty is demonstrated in two proverbs that reiterate the theme of realism and the sovereignty of God in a הבל world (9:11-12). Here Qohelet emphasizes that "time and chance" take precedence over "speed, strength, wisdom, brilliance, and education," thus again noting that wisdom always takes second stage to the sovereignty of God. ${ }^{64}$

In an example story on the value of wisdom (9:13-18), Qohelet again examines that wisdom, although of great profit and pragmatic value in the affairs of life under the sun, does little to counter the effects of life in a הבל world. ${ }^{65}$ So although "wisdom is better than strength," wisdom does nothing to bring about יתרון, whether this be gain in

\footnotetext{
${ }^{62}$ Donald K. Berry, An Introduction to Wisdom and Poetry of the Old Testament, (Nashville: Broadman and Holman, 1999), 168.

${ }^{63}$ Frydrych, Living under the Sun, 193.

${ }^{64}$ While "time and chance" may seem fatalistic, Qohelet has repeatedly acknowledged that the hand of God is behind what is perceived "under the sun" as being nothing more than "time and chance." Nevertheless, it should be noted that any reference to the sovereignty of God in Qoh 9:11-12 is not explicit or overt; it is merely derived from other texts that highlight God's immanent control over man's future and the inability of man to secure the outcome of anything that he does.

${ }^{65}$ For an overview of the genre of "wisdom narrative," of which "example story" is a part, see Andrew E. Hill, Cracking Old Testament Codes: A Guide to Interpreting the Literary Genres of the Old Testament, ed. D. Brent Sandy and Ronald L. Geise, Jr. (Nashville: Broadman and Holman, 1995), $265-67$.
} 
the form of a legacy or profit in the sense of something that is impervious to the injustices of life in a הבל world.

Qohelet 10:1 through 11:6 constitutes a rather large segment of proverbial wisdom that seems to lack a unifying structure, although the motif of wisdom is certainly highlighted throughout. In particular, the pragmatic wisdom contained within this unit emphasizes the art of taking risks, assessing potentiality, and working within a probabilistic paradigm. In critiquing the practical aspects of Qohelet's wisdom, Frydyrch writes, "This ability to assess risk and be prepared accordingly is, alongside the "seize the day" principle, the second critical part of what Qoheleth perceives as wisdom. To express it differently, Qoheleth's wisdom is not deterministic, as the wisdom of the proverbial sages is, but probabilistic. ${ }^{966}$ The popular hermeneutical principle referenced in discussions about wisdom literature-that wisdom statements are "general truths but not iron-clad promises ${ }^{967}$-seems to be assessed and incorporated within the very wisdom of Qohelet. The proverbs contained within Qohelet emphasize risk taking with balance and caution. ${ }^{68}$ One should be aware that there are no guarantees in life, but one must also be willing to take risks-in such a short life one must take chances in order to prosper! ${ }^{69}$

\footnotetext{
${ }^{66}$ Frydrych, Living under the Sun, 194-95.

${ }^{67}$ Fee and Stuart, How to Read the Bible, 220-22.

${ }^{68}$ The wisdom of Qohelet is, if anything, balanced in its approach to life. Thus Frydrych is correct in sensing the balance inherent in Qohelet's view of risk taking when he writes of 11:1-6, "A balance needs to be struck between avoiding the risk and missing the chance." Thus, for Qohelet, wisdom more than simple knowledge or timing; it incorporates the ability to combine these within the framework of a probabilistic worldview. Wisdom suggests that while there are no guarantees in the future, one must still take action and make decisions that in the end are more than not likely to succeed. See Frydrych, Living
} under the Sun, 193-96.

\footnotetext{
${ }^{69}$ See especially Qohelet 11:1-6.
} 
Finally, the wisdom of Qohelet is astutely aware of the presence of God in the affairs and destinies of mankind. A wise person will thus heed caution and remember God in all that he does, because he is ultimately accountable for his actions committed in the few short years of his life. The wisdom proverbs of Qohelet strike a wonderful balance between risk taking, caution, propriety and pragmatism, all in accordance with the overriding motifs and interest areas in Qohelet's greater line of argument, including the fear of God. Although the fear of God is not explicitly linked to or encapsulated in the wisdom of Qohelet in the same sense that it is in Proverbs, nevertheless a lack of fear is clearly viewed as the bane of fools (5:1-7; [Hebrew 4:17-5:6]). The fear of God in Qohelet is not simply an afterthought or relegated to the epilogue; it is intricately tied to the line of argument within the main text $(3: 14,17 ; 5: 7$ [Hebrew $5: 6$ ]; $7: 18 ; 8: 12-13$; 12:1). If the limitations of human wisdom are set in place by God so that man might fear God (3:14), and if true wisdom recognizes these limitations in light of God's purpose, then there is a direct link between Qohelet's theology of wisdom and the fear of God. In this sense, Qohelet's theology of wisdom is in full agreement with the mainstream of canonical wisdom. ${ }^{70}$

\section{Concluding Thoughts}

In the conclusion to the book (12:9-14), Qohelet (referenced in the third person) is affirmed as one who is "wise" and who has "imparted knowledge to the people." Furthermore, it is stated that "what he wrote was upright and true." Whether these words

\footnotetext{
${ }^{70}$ While Fox is correct in stating that "Qohelet never says that wisdom ensues from righteousness or fear of God," he nevertheless is incorrect in relegating the link between the two solely to the postscript (Fox, A Time to Tear Down, 94; 373-74). Frydrych and Seow rightly propose a tighter link between Qohelet's wisdom, the fear of God, and the "sapiential mainstream." See Frydrych, Living under the Sun, 199 and Seow, Ecclesiastes, 69.
} 
originated with Qohelet or with a later commentator is not important; in either case, they confirm the general approach that should be taken to the book. Qohelet ought to be studied as a wisdom book, and furthermore, ought to be approached from a positive perspective rather than from a negative one. Despite the clear consistency demonstrated throughout the book, many scholars continue to argue for multiple voices in Qohelet, some voices (or one) modeling wisdom and others (or another) who do not. Raymond Dillard and Tremper Longman III note in their introduction to Qohelet: "Two voices may be heard within the book of Ecclesiastes, Qohelet's and the unnamed wisdom teacher who introduces the book in the prologue [1:1] and evaluates Qohelet [the speaker in 1:29:8 apart from 7:27] in the epilogue. Qohelet is a doubter and a skeptic; the unnamed speaker in the frame is orthodox and the source of the positive teaching of the book." ${ }^{71}$ This view, however, is simply not supported by the text. First, it should be noted that this "unnamed wisdom teacher" calls Qohelet "wise" (12:9), and labels his words as "upright and true" (12:10). Furthermore, Qohelet claims that his own quest is pursued through the lens of wisdom $(1: 13,16-17 ; 2: 3,9)$ and he never backs away from such claims anywhere throughout the book. Not only does the text warrant against such a view of dual authorship, but, as Michael Eaton has stated, it is quite "absurd" to think that an editor would issue a book that he fundamentally disagrees with. ${ }^{72}$

While it may be appropriate to define the book of Qohelet as skeptical wisdom according to Crenshaw's definition of skepticism, a better approach may be to simply understand that Hebrew wisdom literature by its very nature will tend to exhibit

\footnotetext{
${ }^{71}$ R. B. Dillard and Tremper Longman III, An Introduction to the Old Testament (Grand Rapids: Zondervan, 1994), 253.

${ }^{72}$ Eaton, Ecclesiastes, 41.
} 
characteristics of skeptical faith. Skepticism in this sense is recognition of reality; it might best be explained as a realism that seeks to understand the world as it exists. For this reason, Qohelet must be interpreted with the tension of realism in mind.

Furthermore, skeptical wisdom does not test wisdom in order to destroy its foundations or veracity, but rather, "to affirm many of its truths and teachings, e.g. revering God (3:14; 5:6 [ET 5:7], keeping to cultic obligations (e.g. 5:3-4 [ET vv.4-5]), the value of knowing about 'appropriate' timing and behavior, and the operations of chance (e.g. 3:1-11; 9:11, 13-16)--truths which also belonged to Israel's 'older' wisdom (e.g. Prov 15:23; 23:1-3; 25:11;27:1, 14)." ${ }^{973}$ The common approach that Qohelet constitutes a crisis in wisdom or an attack on traditional wisdom is both overstated and misleading. The truth is that Qohelet, while testing wisdom as to its relative relationship with other motifs, nevertheless "affirms the many wisdom topics that he touches on and encourages his hearers back to wisdom's central focus, which is the pursuit of wisdom and the enjoyment of life." 74 Therefore, the wisdom of Qohelet should be read much in the same fashion as that found in the book of Proverbs, all the while keeping note of Qohelet's unique line of argument, worldview, and stated purpose. ${ }^{75}$

While the historical/critical approach will completely miss the point of Qohelet's line of argument by attributing contradiction to multiple authorship, so too others may

\footnotetext{
${ }^{73}$ Koh, Royal Autobiography, 200.

${ }^{74}$ Ibid, 204.

${ }^{75}$ The fact that Qohelet should be read as wisdom is essential in developing a proper hermeneutic for the book. This of course ties into the thesis of this dissertation. The key to finding a balanced approach to Qohelet is to read the book in light of the inter-dependency of the prominent motifs, wisdom being one of those motifs. The role of wisdom, however, reaches beyond its arrangement as a motif of central concern for Qohelet. Wisdom entails the very perspective from which the book was written, and the genre through which the book was communicated. Therefore, Qohelet must be read as a wisdom text in all of these
} aspects if it is to be properly understood. 
miss the point by seeking a black and white, either/or approach in Qohelet's thought. Qohelet was neither a backslidden pessimist acting as a foil against the wisdom of God, nor was he an eternal optimist turning away from the obvious realities of life observed in a הבל world. Qohelet struggled to make sense of what he saw, and did not necessarily resolve the problems that he encountered along the way. Nevertheless, for him this pursuit itself entailed wisdom, for true wisdom will learn to respect the realities observed in a הבל world as much as it will seek to resolve them. 


\section{CHAPTER 5}

\section{HOW INSCRUTABLE ARE THE WAYS OF GOD! THE RELATIONSHIP BETWEEN GOD AND MAN IN THE BOOK OF QOHELET}

As a wisdom text, the book of Qohelet does not lend itself to theological exposition, for wisdom is by its very nature practical, and as already argued, the primary thrust of Qohelet's purpose is to establish a practical, if not paradigmatic, wisdom based approach to living in a fallen world. However, in the pursuit of this practical end, Qohelet nevertheless explores the nature of the cosmos, God, and humanity to such an extent that one cannot help but extrapolate significant theological insight from the written text. Furthermore, the relationship between God and man are intricately tied to the line of argument throughout the book, and the theology of both is demonstrated to be foundational to an accurate understanding of the cosmos, wisdom, and the everyday part man plays in the Grand Scheme of things. ${ }^{1}$

From the perspective of motif, Qohelet's theology of God and theology of man function as contrastive and complimentary, with the sovereign determinacy of the deity set in relationship to and against the imposition of limitation upon humanity. Throughout the book of Qohelet one finds cosmological tension between the infinite Creator and his

\footnotetext{
${ }^{1}$ Frydrych refers to the "theo-cosmological" worldview of Qohelet, whereby "divine design has a natural tendency toward equilibrium between what is in some sense bad and detrimental to human beings, and that which is good and beneficial for them." In this sense, Frydrych expands the theological discussion to incorporate a view of the cosmos that extends beyond theology and anthropology. Frydrych argues in the end for an "Even-Steven" cosmology, one in which God's sovereign control and the limitations imposed upon mankind are designed to result in equilibrium. It is this "equilibrium by design" that frustrates Qohelet, for no lasting can be found in a world destined to equilibrium. In a sense, Frydrych, while preferring Fox's gloss "absurd," is arguing that "equilibrium" is the key element in Qohelet's use of the key word See Frydrych, Living under the Sun, 43-44 and 122-23.
} 
finite creation, and this relationship between the two forms a primary area of inquiry for the reflective sage. As with the other motifs explored by Qohelet, the motif of "sovereign imposition of limitation" does not function as independent from the other motifs under consideration, but rather, is intricately tied to the others as Qohelet's line of argument is developed throughout the book. Therefore, it is the goal of this chapter to explore Qohelet's theology of God and theology of man, not as a resource for the development of systematics, but as a motif inner-dependent within itself and inter-dependent among the other prominent motifs in the book.

Alluding to the inner-dependent relationship between the sovereign determinacy of God and the imposition of limitation upon humanity, Seow refers to this aspect of Qohelet's work as "theological anthropology," that is, theological reflection that "begins with humanity, but [it] also reflects on the fate of humanity in God's hands and [it] speaks of the mysterious ways of God."2 The relationship between the two in Qohelet's theology does not denigrate one against the other, but develops an understanding of how the two relate to one another. Thus one cannot speak about Qohelet's theology of God without also alluding to his theology of man; the two are tightly related throughout his line of argument, both textually as well as theologically. ${ }^{3}$

Qohelet's treatment of the two is balanced and honest, even if it does not paint an entirely complete picture of God or of mankind. Of course, Qohelet's concern is not to present a systematic theology of either, and his interests are certainly limited by his purpose, if not also his revelation knowledge. His interest is, however, to expound upon

\footnotetext{
${ }^{2}$ Seow, Ecclesiastes, 54.

${ }^{3}$ Concerning the inner-dependent, yet non-denigrating relationship between the two, Brown writes, "Shrouded in mystery, God is free from human manipulation, not at the expense, but in full acknowledgement of humanity's frail identity." See Brown, Ecclesiastes, 133.
} 
his own recognition of the "immeasurable chasm between ephemeral humanity and eternal divinity," and with an ever practical goal in mind, to propose that this contrast "is the very telos of divine activity: 'for God has acted so that [mortals] may fear him' (v. 14c)." "Thus, in the end, while an exploration of Qohelet's "theological anthropology" is relevant, the main purpose in Qohelet's treatment of the issue was to descend from the theological to the practical, and thus this chapter too will seek to extract a proper understanding of the divine purpose behind the imposition of limitation upon humanity.

\section{Sovereignty and Determinacy in Qohelet's Theology of God}

Scholars and popular readers have traditionally viewed the God of Qohelet as a "sovereign despot," unconcerned with the plight of man and for some, antagonistic towards him. ${ }^{5}$ When taken positively, the God of Qohelet is "wholly transcendent," the primary stress emphasized in this transcendence is the "otherness" of the Creator. ${ }^{7}$ Indeed, for nearly all commentators, the distance between God and man appears to be central to Qohelet's “theological anthropology,"as Qohelet himself makes startlingly clear: "God is in heaven, but you are on earth (5:2 [Hebrew 5:1])." ${ }^{, 8}$ Taken negatively, such separation has caused some to conclude that Qohelet's God "stands distant,

\footnotetext{
${ }^{4}$ Lee, Vitality, 43 .

${ }^{5}$ Frydrych, Living under the Sun, 109.

${ }^{6}$ Seow, Ecclesiastes, 56.

7 In reference to Qoh 5:7 [Hebrew 5:6], Lee alludes to the Creator as "Wholly Other," adding emphasis to the thematic separation between God and man in Qohelet. See Lee, Vitality, 91-98.

${ }^{8}$ Seow, Ecclesiastes, 56. Seow makes an interesting comparison to Daniel 4:39 (God is in heaven above and on earth beneath) by stating, "Qohelet appears to be so intent on avoiding any reference to divine immanence that he does not even risk the language of divine omnipresence."
} 
abandoning humanity to chance and death;", indeed, it can be said that "in Qohelet, the oppressed have no comforter, none at all (Qoh 4:1)." ${ }^{10}$ Following this negative approach to transcendence, Fox suggests that the God of Qohelet "does not seem to love mankind, nor does Qohelet seem to love him," and indeed, the presence of love does seem to be missing from the relationship between Qohelet's God and his creation. ${ }^{11}$

In spite of the relatively negative impression of God that Qohelet gives to most readers, his presentation of theology proper is not out of sync with the rest of canonical literature, even if its emphasis is thematically particular. Qohelet references divinity 40 times, exclusively using the term אלתים rather than the covenantal name יהוה. Various suggestions have been made as to the purpose of such a uniform choice (after all, Qohelet was obviously familiar with the Hebrew cult, e.g. Qoh 1:1, 16; 5:1-7 [Hebrew 4:17-5:6], and presumably was also familiar with the covenantal name), although common consensus has it that Qohelet's goal was to emphasize the transcendence of God rather than the personal, immanent side of his relationship with man. ${ }^{12}$ In any case, Qohelet

${ }^{9}$ Crenshaw, Ecclesiastes, 23.

${ }^{10}$ Fox, A Time to Tear Down, 137. Fox continues, "Qohelet's God is hard and mostly indifferent but not hostile. He has created an orderly world and set things running so that everything has its right and appropriate circumstance. We can be confident that God will act at the right time - for himself if not for us."

${ }^{11}$ It should be noted that Qohelet never suggests that God does not love mankind, although the text does attribute the source of (evil) afflictions to God $(1: 13 ; 3: 10)$. See Anderson, Pessimistic Theology, 99-101.

\footnotetext{
${ }^{12}$ Taking a slightly different track, Frydrych suggests that the choice is born out of theological purpose: "Qohelet does not seek to answer the question - 'Who is the one true God?' (Yahweh), but rather, 'What is God like?' (Elohim)." See Frydrych, Living under the Sun, 108. Lohfink too concludes that "[I]t is completely inappropriate, however frequently it is done, to conclude from the absence of God's name in the text to any cooling or depersonalizing of Qohelet's relation to God." Rather, Lohfink views this absence as a result of the Hellenistic context in which he places the event behind the text: "If Qohleth throughout the book speaks only of 'God,' without ever using the ancient name 'Yahweh' for God, this is easily understood hundreds of years after the establishing of monotheistic thinking in Israel, and in a context in which, on the one hand, this name is more and more abused in popular magic. We must also take into account a certain formulaic pressure from the language of Greek philosophers who made fun of
} 
always assumes that his readers are familiar with the God of Israel; his text is

"thoroughly monotheistic" and he makes no attempt at an apologetic against polytheistic theology. ${ }^{13}$

Although the transcendence of God is emphasized throughout the text, this is not to the complete exclusion of immanent activity. Indeed, the goodness of God is cited as at least partial reason behind his enablement of mankind to enjoy life $(2: 24 ; 3: 13 ; 5: 19$; $8: 15) .{ }^{14}$ In describing a balanced approach to Qohelet's theology of God, ${ }^{15}$ Brown writes, "Transcendent and immanent, absent yet subtly present is Qohelet's God.".16 Indeed, a proper view of God in Qohelet, while emphasizing the eternal "otherness" of God, does in fact reflect a canonical theology balancing transcendence and immanence. In response to the activities of man, God's personality is revealed (he hears, 5:2; despises, 5:2; is pleased, 2:26; 7:26; or angered, 5:26), his goodness is expressed (he is the giver of opportunity, 5:19-20; 9:7; wisdom, knowledge, and happiness, 2:26; and wealth, possessions, and honor $5: 19-6: 2)$, and his justice is felt $(3: 17 ; 11: 9)$. God is said to be holy (5:1-2 [Hebrew 4:17-5:1]), and the holiness of God elicits a response of reverence

polytheism." Such speculation, however, is far too dependent upon cultural and religious reconstructions of an uncertain background to garner much confidence. See Lohfink, Qoheleth, 47.

${ }^{13} \mathrm{Ibid}, 107$. Although an argument from silence, it is interesting that there is no apologetic against polytheism if one is to argue for a pre-exilic, Solomonic origin for the text. However, the pervading context of kingly rule combined with cultic observance $(5: 1-7)$ would seem to suggest a pre-exilic period of origin. Obviously, this issue lacks clear, decisive evidence either way.

${ }^{14}$ Lee develops an extensive line of argument linking the enjoyment of life with the enabling power of God's choice; in a sense, enjoyment rests in the will of God. She summarizes her point by stating, "When all is said and done, the possibility of good ultimately comes from the hand of the divine Sovereign (Lee, Vitality, 37)." For a more extensive treatment of Lee's rationale for linking the enjoyment of life to the Sovereign hand of God, see chapter 7 of this dissertation. balanced!

${ }^{15}$ If this study arrives at any conclusion about Qohelet, it is (if nothing else) that the wise sage is

${ }^{16}$ Brown, Ecclesiastes, 133. 
on the part of mankind (5:7 [Hebrew 5:6]; 12:1). Although selective in scope, a survey of the attributes of God within Qohelet reveals a God who is quite consistent with the theology of the rest of Scripture. ${ }^{17}$

Even while accepting the canonical consistency of Qohelet's theology of God, one nevertheless is confronted within Qohelet with repeated references (usually in the form of proverbs) to the sovereign determinacy of the Creator. Key proverbs on sovereignty, determinacy, and the perception of fate include Qoh $1: 15 ; 6: 10 ; 7: 13-14$ and $9: 11-12$; it should be noted that the common theme within these proverbial threads is consistent throughout the book. In the view of some, these references to determinacy suggest a fatalistic worldview leading to a pessimistic approach to Qohelet's theology. Berry writes, "Behind all of Qohelet's pessimism rested a fatalism that read life's ambiguity as divinely predetermined," and further offers that "it is the recognition of fatalism that led to Qohelet's confession, 'So I hated life' (2:17)."18 Although many commentators recognize a link between determinism, fatalism, and a pessimistic worldview, William Anderson is certainly without equal in his advancement of pessimism as the overarching worldview of Qohelet. In regards to the above cited proverbs, Anderson writes, "Qoheleth certainly viewed God as absolutely sovereign-and in the light of much evil, injustice and incongruities in the world-must thus hold God responsible. ${ }^{19}$ In attributing the source of all things to God, Anderson furthermore

\footnotetext{
${ }^{17}$ Roy B. Zuck, "God and Man in Ecclesiastes," Reflecting with Solomon, ed. Roy B. Zuck (Eugene: Wipf and Stock, 1994), 218.

${ }^{18}$ Berry, An Introduction to Wisdom, 163.

${ }^{19}$ Anderson, Pessimistic Theology, 97.
} 
questions the very morality of God: "God may be the Creator and sovereign-but in light of his capricious determinism-this raises the question: Is he moral?"20

Although even an optimistic reading of Qohelet will likely concede the limitations that man has in controlling what ultimately is controlled by God, ${ }^{21}$ the deterministic perspective that Qohelet has of God in no way demands the oft assumed descent to the despair of fatalism. ${ }^{22}$ In spite of the sovereign providence that the Creator wields over the affairs of man, Qohelet's theology of God does not exempt human beings from responsibility. To the contrary, Qohelet confronts sovereign determinism with a sense of human responsibility born out of pragmatic wisdom; it is a responsibility that embraces the open potential of the future balanced by a recognition that ultimate control rests in the hands of God. Thus, rather than the despair of inactivity wrought by the shackles of fatalism, a proper understanding of Qohelet's deterministic theology results in the liberation of activity, at least as life is phenomenologically carried out. Because God is sovereign, man does not know the future; thus, man must act according to a wisdom rooted in the concepts of possibility and probability, which is exactly the kind of wisdom

${ }^{20}$ Ibid, 103.

${ }^{21}$ Anderson advances that Qohelet's fatalistic view of God's sovereign determinism, in leading to a pessimistic worldview, provides the practical basis behind Qohelet's lack or reference to prayer and supplication. Although admitting that this is an argument from silence, Anderson nevertheless has a point in stating that one should expect prayer to be at the forefront of a discussion on controlling the outcomes of the times and the seasons of one's life. Regarding prayer and sovereignty, Anderson writes, "Qohelet's view of God's absolute sovereignty means that he had no hope of changing God or the way life is under him - and may explain why he nowhere mentions prayer in his book." However, in response to Anderson, it should be noted that wisdom rarely emphasizes prayer as a means to change circumstances and future outcomes; rather, quite in line with Qohelet, wisdom tends to emphasize the probabilistic potentiality of wise decision making and decisive action in affecting the future. On Anderson's thesis regarding the lack of reference to prayer in Qohelet, see Anderson, Pessimistic Theology, 101, 122.

${ }^{22}$ Murphy distinguishes between the terms "determinism" and "fatalism," noting that Qohelet's view is not fatalistic, but rather, deterministic. He furthermore understands determinism as "the sovereign disposition of all things by the divinity," a theology that Qohelet affirms along with the rest of the biblical writers. See Murphy, Ecclesiastes, Ixvii. 
that Qohelet teaches. Lee writes that "Qohelet's theology of determinism (and of the Old Testament in general) does not exempt the human agent from responsibility; neither does it engage in a theoretical discussion concerning the reconciliation of these two contraries. It affirms equally both divine determinism and human responsibility," a tension that Lee refers to as "Qohelet's theology of double agency." 23 Contra Anderson's pessimism wrought from a theology of fatalism, Lee offers that the mystery of God's sovereign determinism should function to motivate the human agent to action. In reference to motivation, Lee writes:

Qohelet then suggests that God's work-precisely because of its mystery and unknowability-may be liberating rather than debilitating for the human agent. It may in fact motivate vigorous activity in both morning and evening: "for you do not know which will prosper, this or that, or whether both alike will be good" (11:6). In this scenario, human beings are not hapless victims in an unpredictable and uncontrollable world. The openness of the unknown future stimulates the human agent to be actively involved in the affairs of the world, to be industrious and diligent in the work at hand, to give liberally and spontaneously to the neighbor, all for the possibility of good. ${ }^{24}$

Although Lee applies such thinking primarily to the realm of human responsibility, divine enablement, and the enjoyment of life, even when limited only to Qohelet's theology of God her insights are valuable; while a deterministic theology is never questioned, the implications of divine control need not lead to fatalistic pessimism. Beyond those proverbs suggestive of theological determinism, Qohelet also incorporates an element of mystery into his theology of God. In reference to man's inability to comprehend the mysterious ways of God (through wisdom, or through any other means), Qohelet states twice over: "yet they cannot fathom what God has done

\footnotetext{
${ }^{23}$ Lee, Vitality, 135-39.

${ }^{24}$ Ibid, 137.
} 
from beginning to end," and "No one can comprehend what goes on under the sun. Despite all his efforts to search it out, man cannot discover its meaning. Even if a wise man claims he knows, he cannot really comprehend it (Qoh 3:11b; 8:17b)." The utter mystery shrouding the works of the Providential Creator is certainly inner-dependant with the imposition of limitation on mankind; it is neither the high mystery of the Creator nor the dull understanding of man which lies as the sole culprit behind this great divide. Rather, the two function together in Qohelet's line of argument as two sides to the same coin, although it might be suggested that God is a proactive agent in keeping man from a fuller understanding of his mysterious ways (Qoh $3: 10,14,18) .{ }^{25}$ In either case, the result of such a divide is developed by Qohelet to its fruition in the revelation of life as הבל.

Quite in line with the "absurdity" family of glosses representative of certain aspects of the הבל symbol, Lee defines the key word הבל as "beyond mortal grasp," at least as contextually understood when juxtaposed against the incomprehensible agency of God. ${ }^{26}$ As Qohelet observes the activity of God in the world, he sees by wisdom the very limitations of wisdom in understanding what God does in relation to his creation. This is a great vexation to Qohelet, and he proclaims it as הבל. Although balanced in distribution,

${ }^{25}$ A key exegetical question regarding the imposition of limitation upon man relates to the above listed texts and the issue of purpose vs. result. Thus some (Ogden, Qohelet, 55-56) would suggest that man's limitations come as a result of God's higher plane, while others would suggest that imposition of limitation is driven by divine purpose. The exegetical details to this question will be taken up later in this chapter.

\footnotetext{
${ }^{26}$ Lee, Vitality, 39. Contra to Lee, Anderson views wisdom as "impotent relative to God's mysterious incomprehensibility." However, in my view (as well, I believe, in Lee's view), wisdom allows one to gain some advantage, however limited, in living life and making decisions in spite of the incomprehensible nature of God's mysterious sovereignty. See Anderson, Pessimistic Theology, 105.
} 
Qohelet underscores the mystery of divine sovereignty by presenting the paradoxical polarities of God's activity. ${ }^{27}$

Tבל The relationship between God's sovereign incomprehensibility, the judgments, and Qohelet's theology of God is demonstrated at multiple levels through the tensions described throughout the text: the lover of money is never satisfied by money (5:10), consumption increases in proportion to wealth (5:11), it is better to go to the house of mourning than the house of feasting (7:2), the wicked are praised at death (8:10), and folly appears in high places (10:5-7) ${ }^{28}$ However, while the ironic nature of דבל w world is apparent in a variety of observances, it is the "crisis" of theodicy that is of the greatest concern to Qohelet. ${ }^{29}$ The very fact that "God is a just judge who allows inexplicable inequities" (Qoh 8:12-14) is for Qohelet a great conundrum; he cannot escape the fact that God's power is not at issue, but rather, his sense of justice. ${ }^{30}$ For Qohelet, the mysterious nature of God's sovereign determinacy is not a matter of debate; it is a statement of fact. As to theodicy, he does not find it necessary to defend God, but he does have an explanation; furthermore, his explanation includes the capacity to incorporate the complete control of the deity in meting out the good and the bad $(9: 1$

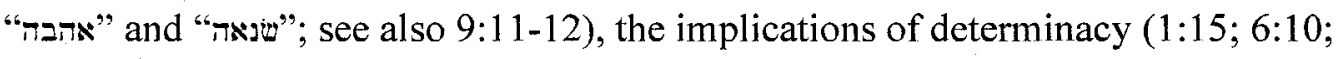

${ }^{27}$ Brown writes, "By claiming that God creates both the 'day of prosperity' and the 'day of adversity,' Qohelet underscores the mystery of divine sovereignty." It is the juxtaposition of such extremes in activity that Qohelet is unable to grasp. See Brown, Ecclesiastes, 133.

${ }^{28}$ For a similar list of ironies in Qohelet, see Berry, An Introduction to Wisdom, 164.

${ }^{29}$ On the oft advanced theory that Qohelet represents a "crisis" in wisdom, (that is, the so-called crisis in wisdom that stems from the problem of inequity in retribution), Murphy remarks that "the crisis is no less than the mysterious ways of the Lord." See Murphy, Ecclesiastes, lxvi. $121-50$.

${ }^{30}$ Fox, Contradictions, 121. For a fuller treatment of theodicy in Qohelet, see Fox, Contradictions, 
namely, that man has no power to change what God has determined), ${ }^{31}$ along with the apparent responsibility of God for good times and the bad (7:13-14). In short, God does it "so that men will revere him (Qoh 3:14b)."

\section{The Imposition of Limitation in Qohelet's Theology of Man}

The "explanation" hinted at above needs further foundation before a more thorough treatment can be given. As suggested earlier, Qohelet's theological anthropology implies an inner-dependence between the sovereignty of God and the imposition of limitation upon humanity; in surveying Qohelet's theology of God it is nearly impossible to not delve into his anthropology. And thus we have come to a point where we must step backwards in our discussion; after detailing some aspects of Qohelet's anthropology it will be possible to look further into God's purpose in determinacy, divine mystery, and the wisdom of man.

Like his theology, Qohelet's anthropology, while limited in scope and perspective, is nevertheless compatible with a canonical theology of man, especially with that of Genesis. ${ }^{33}$ Roy Zuck observes this relationship as follows:

Man was originally created good (Gen 1:31; Eccl 7:29), but fell into sin (Gen 3:1$19 ;$ Eccl $3: 16 ; 4: 1 ; 7: 29$ ), with the consequence of toil (Gen 3:14-19; Eccl 1:3, 8,

${ }^{31}$ Regarding God's complete power and control in divine determinacy, Fox writes: "Man may push and strain against the barriers but cannot budge them, any more than an icon in a video game can rewrite the software that generates its world (Fox, A Time to Tear Down, 137)."

${ }^{32}$ Qoh 3:14 is critical in explaining the nature of the divine/human relationship. In its entirety, 3:14 reads in the NIV, "I know that everything God does will endure forever; nothing can be added to it and nothing taken from it. God does it so that men will revere him." The nature of this endurance will be later taken up in detail in this chapter, however, it should be noted here that God's activity, which does "endure," seems to be set in contrast to the nature of man's works, which do not endure. Lee reminds us of this contrast: "That [in Qohelet the] emphemerality of all human activity is poignantly contrasted with the transcendence of God's activity..." See Lee, Vitality, 43.

${ }^{33}$ While anthropology in Qohelet is not out of step with the rest of Scripture, correlation is most recognizable with the Genesis creation account. See C. C. Forman, "Koheleth's Use of Genesis," JSS 5 (1960): 256-63. 
$18 ; 2: 11,17,22)$ and death (Gen $3: 19,24 ; 4: 5,8 ;$ Eccl 2:14-16; 3:20; 4:2; 9:5;

12:6-7). Made form dust and breath $(2: 7 ; 3: 19 ;$ Eccl $3: 20 ; 12: 7)$, man has limited knowledge (Gen $2: 17$; Eccl $8: 7 ; 10: 14 ; 11: 5)$. He was created to be in companionship with others (Gen $1: 27 ; 2: 21-25 ; \operatorname{Eccl} 4: 9-12 ; 9: 9) .{ }^{34}$

In addition to matters of anthropological origin, Qohelet describes man in terms compatible with a comprehensive biblical theology of man. Throughout the text, Qohelet uses the term "flesh" (בשר) to describe mankind, with a thematic emphasis on the transience of the material man rushing headlong to the grave. ${ }^{35}$ However, in spite of the "dust to dust" point of comparison made between man and beast (Qoh 3:18-20), ${ }^{36}$ Qohelet does recognize an immaterial component to man that is uniquely human. Described using the conventional yet ambiguous terms soul (נפט), spirit (רוח), and heart (בל), man is viewed by Qohelet as an intellectual, volitional, and emotional being who is limited by sin and a finite perspective, ${ }^{37}$ yet responsible to himself, God, and others for the decisions that he makes and the activities that he pursues. ${ }^{38}$ Qohelet's view of man, both material and immaterial, is therefore consistent with the presentation of these anthropological entities elsewhere in Scripture. ${ }^{39}$ Most significantly, at death, the body of

${ }^{34}$ Zuck, "God and Man," 221.

${ }^{35}$ Certainly even Paul would affirm Qohelet's view of the corruptible flesh (1 Cor 15:35-49), even though Qohelet did not describe, nor was aware, of the resurrection body that is incorruptible.

${ }^{36}$ Note that Qohelet is not alone in comparing man with the beasts in regards to the corruptible flesh (Ps 49:12, 20).

\footnotetext{
${ }^{37}$ By using these terms to describe the immaterial nature of man, I am not suggesting a theological correlation of spheres between the soul and man's intellect, the spirit and man's volitional capacity, or the heart and emotional side of man.
}

${ }^{38}$ Zuck lists man's responsibilities (as outlined in Qohelet) as follows: 1) Be wise, 2) Worship and please God, 3) Remember God, 4) Fear God, 5) Be diligent, and 6) Enjoy life. There is a significant relationship between man's responsibility as an agent of potentiality and the nature of probabilistic wisdom in Qohelet. See Zuck, "God and Man," 221-22.

${ }^{39}$ Of great theological concern is Qohelet's apparent uncertainty regarding the destination of man's spirit after death (Qoh 3:21). Although the ramifications of this question do apply to Qohelet's anthropology, the more significant concern is in the realm of personal eschatology. Therefore, Qoh 3:21 
flesh is depicted as dust returning to the ground from whence it came (Gen 2:7a; 3:19;

Qoh 12:7a), while the spirit of man (or his immaterial being), mirroring the breath of life

(Gen 2:7b), returns to the One who gave it (Qoh 12:7b; Gen 3:19).

While Qohelet affirms the basic tenets of anthropology rooted in creation and the fall, he does extend the canonical picture of man with an emphasis on man's limitations, especially as imposed upon him by his Creator. Of particular interest to Qohelet is the observation that man has no ultimate control over his future or that of any one else, whether it be within the scope of his own life or the years that follow him after his death $(3: 22 ; 6: 12 ; 8: 7 ; 9: 1 ; 10: 14 ; 11: 2)$. In the same vein, man's influence is limited in that he has no lasting legacy for all his labors performed during the years of his life, no matter how significant his achievements might have been $(1: 11 ; 2: 16,18,19,21 ; 9: 6,15)$. Ultimately, such lack of knowledge and influence is not limited to man and his own world of association, but it extends even to his relationship with God. Central to Qohelet's view of man is the fact that man cannot fathom anything regarding divine choice and action $(3: 11 ; 8: 16,17 ; 11: 5)$; in fact, such an imposition of limitation is viewed by Qohelet as a burden that God has laid upon man $(1: 13 ; 3: 10 ; 6: 1 ; 8: 6)$, and furthermore, functions as a means by which man may be "tested" by his Creator $(3: 18) .^{40}$

and $12: 7$ will be addressed in greater detail within the next chapter on the inevitability of death motif in Qohelet.

${ }^{40}$ Other writers have noted the variety of means by which Qohelet demonstrates the limitations of man. Frydrych suggests the following list: 1) man is limited by the imposition upon his ability to understand the way the world functions; 2) man is limited by the great equalizer, death; 3) man cannot accomplish anything permanent; and 4) man is subject to the same lack of justice. Anderson too suggests a helpful list of limitations, although the following is condensed and summarized from his prose: 1) man is limited by the cyclical nature of life; 2) man is limited by time and space; 3) man is limited regarding knowledge of the future; 4) man is limited by a lack of enduring legacy; and 5) man's epistemological limitations are most strikingly clear in the limitations of wisdom. See Frydrych, Under the Sun, 152-53 and Anderson, Pessimistic Theology, 125-65. 
Human finiteness evidences itself through a variety of means, but perhaps no

other limitation underscores the folly of prognostication more than man's ignorance regarding the future..$^{41}$ The limitation of man's temporal knowledge is further heightened throughout the book as it is set in contrast to the limitless knowledge of God, a knowledge that rests in the eternality of the Creator (Qoh 3:1-15). ${ }^{42}$ The repeated and clear references to man's ignorance of the future $(3: 22 ; 6: 12 b ; 8: 7 ; 9: 1 ; 9: 12 ; 10: 14 ; 11: 2)$ plays a two-pronged role in Qohelet's line of argument. The above stated references are based in context to a variety of prominent motifs, including the inevitability of death $(3: 22 ; 9: 12),{ }^{43}$ the ephemeral nature of man $(6: 12),{ }^{44}$ and probabilistic wisdom $(11: 2),{ }^{45}$ yet within each reference lies the underscoring contrast set between man and God. Thus, one could argue that man's lack of knowledge regarding the future stems directly from

\footnotetext{
${ }^{41}$ Qohelet bears out the folly of prognostication in a proverb (10:14): "And the fool multiplies words: No one knows what will happen. Who can tell anyone what is going to happen after him?" Regarding the broader passage (10:12-14), Longman observes that "the fool is going on and on about something for which he has no information and about which he can gain no knowledge: the future." See Longman, Ecclesiastes, 248.
}

${ }^{42}$ Anderson writes in reference to Qoh 1:18, "There are a number of other places in Qoheleth where the author dealt specifically with the limitations of human knowledge-often in contrast to the seemingly limitless knowledge of God." Certainly this contrast underlies many of the statements throughout Qoh 3:1-15, however vague and enigmatic the precise meaning of these statements might be. See Anderson, Pessimistic Theology, 149.

${ }^{43}$ Although the overriding context of 9:11-12 implies man's lack of control over unfortunate "incidents" that may lie in his future, Seow sees the underlying "incident" from which no one escapes as being central here-"that is, the time of death"-of which "no one knows when that will be $(9: 12 ; 10: 14$; see also 7:17). He furthermore suggests an emphasis on how utterly unpredictable the timing of such an "incident" might be, and thus "everything is subject to chance." See Seow, Ecclesiastes, 321.

${ }^{44}$ Longman ties man's lack of knowledge back to his ephemeral nature, stating, "God has made human beings ephemeral, and that is why they cannot know the future, either theirs or anyone else's." See Longman, Ecclesiastes, 179.

${ }^{45}$ Longman affirms Qohelet's view regarding the uncertainty of the present and the future when he states, "In terms of the message of the book as a whole, Qohelet has consistently maintained the uncertainty of life in the present world (Ibid, 256)." While Longman is correct in his assessment of this aspect of 11:1-6, he fails to consider the positive thrust of Qohelet's wisdom throughout this passage. Qohelet's wisdom is best described as probabilistic (and this is an admittedly positive perspective), and it is the uncertainty regarding the future that proves to be the catalyst for much of Qohelet's wisdom. Qohelet's probabilistic wisdom tackles life's decisions and its opportunities in light of its uncertainties. 
his ephemerality, or one could argue that it is the boundless bar set by the Creator that establishes the limitation, but in neither case does Qohelet seem especially bothered by the situation as much as he is by his suspicions that God has intentionally established it as such.

Frydrych sets this particular perspective in contrast to that in Proverbs, where the sage commends wisdom as God's desire for man, while in Qohelet God seems intent in keeping man from knowledge. Contra the open invitation of Proverbs 9:1-6, Frydrych notes that in Qohelet "ignorance is ultimately something that God desires," and that "the quest for understanding cannot be completed, the world is not fully comprehensible and never will be because God intended for it not to be. ${ }^{46}$ However, Qohelet is not disparaging of wisdom in the sense that he would discourage his readers from pursuing it, nor would the God of Qohelet discourage the pursuit of wisdom. Rather, the wisdom that Qohelet espouses is that which enables mankind to live wisely in a world of limited knowledge and perspective, especially as regards the future. So one might say that Qohelet's theology of God indicates a divine intention to limit man in his knowledge of the future (at least in the guaranteed sense), yet in practice Qohelet encourages man to live successfully in the present through the implementation of probabilistic wisdom. God's desire is not to limit man's ability to access knowledge in the present nor to deceive him regarding the future, but Qohelet is certainly convinced that man is inherently unable to with confidence know the future (due to his finite perspective). Thus,

\footnotetext{
${ }^{46}$ Following his statement that "God intended it not to be," Frydrych continues by quoting Qoh 8:17 via his own translation: "Then I saw [concerning] every activity of God, that a person is not able to find out [about] the activity which is happening under the sun, no matter how much a person may work to search [it] out, he cannot find [it] out, and even if the sage should say that he knows, he cannot find [it] out." See Frydrych, Living under the Sun, 48, 76.
} 
God's intention is such that man is kept in his place by his inherently limited perspective, yet it is fully to the benefit of man that he recognizes his own limitations and learns to live wisely in view of them. ${ }^{47}$

Not only is Qohelet observant of man's inability to access knowledge of the future, he also is troubled by man's lack of ability in securing a lasting legacy from past acts and achievements. In Qoh 1:11 and 2:16 Qohelet relates in the context of his own first person experiences the fear that his works and achievements will leave no lasting legacy upon future generations (even the wise man will not be long remembered), and further carries this theme throughout the text in the propositional statements of 9:5-6 (the memory of the dead is soon forgotten) and the example story of 9:15 (the poor but wise man is not remembered). Furthermore, as bothered as Qohelet may be from man's inability to secure a lasting legacy, he is just as troubled by the fact that all his achievements will be handed down to someone who has not worked for them, and this Qohelet proclaims is Sב. $^{48}$ To add insult to injury, Qohelet also condemns the ironic fact that the one who follows after him may potentially be a fool, and could end up squandering all that he has worked for and achieved by his diligence and wisdom (2:19).

\footnotetext{
${ }^{47}$ Frydrych takes an approach that puts the onus of intention on the shoulders of God: "In fact, he is convinced that it is the divine intention to demonstrate to humans that they are nothing more than earthly beasts, whose existence is fragile and without any genuine lasting aim; the human being is just a הבל." While it is true that God does not desire that man think more highly of himself than he ought, it is not in Qohelet's view that God subjugates mankind to a condition that he is not already inherently possessed of. In other words, man is finite, and it is in his own best interests to recognize this as true, to recognize the distinctions between himself and God, and to learn to live wisely in the present, all the while preparing for an uncertain future (at least so far as man's knowledge can tell). See Frydrych, Living under the Sun, 149.

הבל הבל judgments in 2:19 and 2:21. Furthermore, Qohelet qualifies these judgments with the decisively negative statements "I hated life" (vs 17) and "I hated all things" (vs 18), along with the qualifier in vs 21, "רבה ירעה" (a great evil).
} 
Coupled together, the inevitable spectre of death and the general ephemerality of man's transient state (one aspect of his "hevelness") obliterates any hope that an individual may leave a lasting legacy, something by which his achievements may transcend his own finitude. The תרון sought by Qohelet cannot be found in building a legacy; Qohelet's theology of man expresses a finitude that expands beyond one's life to even touch upon the lasting value of one's own legacy. ${ }^{49}$

Along with ignorance regarding the future and impotence regarding one's own legacy, man falls short in his ability to comprehend even the most immanent activities of God $(3: 11 ; 8: 16-17 ; 11: 5)$. Qohelet's theology is in one sense "a-theological;" finite beings can simply not fathom the infinite! Man does not know the future, cannot control the present, and has little power to make good on the past. He is not only limited in his knowledge of time and his control over reality, but he cannot fathom the rationale behind the God to whom responsibility and knowledge exists. Seow reflects Qohelet's epistemology by stating, "In reality, humanity can only accept what God does, but he cannot 'know." ${ }^{, 50}$ And thus, Qohelet's wisdom is a wisdom of the present, a way to capitalize on an unsure future and a present that cannot be controlled. Qohelet is not able to fathom God's inscrutable ways, but his lack of control and understanding does not

\footnotetext{
${ }^{49}$ In commenting upon Qoh 1:11, Murphy links the impotency of memory to the cyclical monotony of nature: "Memory is as flat as the experience described in vv 3-8, and it does not serve to liberate humans from the monotony of life." However, I would suggest that Qohelet's point is not simply that humans too are caught up in the cyclical nature of the cosmos; he is emphasizing the very real limits that man has in producing a legacy of lasting value and influence. See Murphy, Ecclesiastes, 9.

${ }^{50}$ Seow, Ecclesiastes, 50. There is a striking irony in Qohelet's conclusions regarding the ability of man "to know" and the approach that many commentators have in evaluating Qohelet's epistemology. Representative of many scholars, L. Lowell Smith reflects this view in writing, "Reason is elevated throughout the whole work as the tool with which man may seek and find truth." However, Qohelet's theology is suggesting the exact opposite - man cannot know anything so far as God's providence and sovereignty are concerned! See L. Lowell Smith, "A Critical Evaluation of the Book of Ecclesiastes," JBR 21 (1953): 105.
} 
render him powerless. Lee reflects upon this opportunistic wisdom when she writes, "Finite beings cannot grasp the infinite. But there are some things that human beings can indeed find and grasp with their hands: those things that are immediately before them." ${ }^{, 51}$ For this reason, while Qohelet never concedes to the adequacy of human knowledge, nor is he ever satisfied by his knowledge of divine rationale, he nevertheless succeeds in shifting his conclusions to the realm in which man does have control, that is, his ability to enjoy the present. ${ }^{52}$ Nevertheless, Qohelet never suggests anything other than the point that God has in some way kept man weighed down by his own finite existence.

It is self evident that man is limited by his own finitude, a situation that could be labeled as passive. However, Qohelet takes the discussion one step further by suggesting the imposition of limitation, that is, that God has purposefully burdened man with the weight of his own finitude. In suggesting an active role on the part of the Creator, Qohelet squarely places the responsibility of human limitation on God's shoulders. Furthermore, he implies that such imposition is with a purpose in distinguishing between the divine and the mortal.

The imposition of limitation is implied throughout Qohelet's reflections in "theological anthropology," yet becomes most pointed in the rather cryptic phraseology found in 1:13 and 3:10 ("What a heavy burden God has laid on men!" and "I have seen the burden God has laid on men ...", NIV) and with some variation, in 6:1 and 8:6 ("I have seen another evil under the sun, and it weighs heavily upon men ..." and "...

\footnotetext{
${ }^{51}$ Lee, Vitality, 68.

52 In a similar vein of thought, Lee writes, "Mortals are powerless to control the work of God; their agency is bound to the ethic of the moment." As suggested above, Qohelet's recognition of man's limitations to the present provide rationale for his conclusions to enjoy life, for it is only in this realm that man has even relative power and control. See Lee, Vitality, 57.
} 
though a man's misery weighs heavily upon him.", NIV). The term translated by the NIV translators as "burden" in 1:13 and 3:10 ענין רעי (עין for "heavy burden"), and the "evil" and "misery" that weighs "heavily" upon men are in both cases translated from the ambiguous term רעה, used throughout Qohelet to refer more to frustration and burden than to moral evil $(6: 1 ; 9: 3)$. As one sees the prominence and position of this repeated phraseology within Qohelet, one cannot help but ponder its role as an entity describing the imposition of limitation upon man. What is this "burden" or "task" imposed upon man, and for what purpose has God instituted such a "burden"?

The term עניץ is found nowhere else in the Hebrew Bible outside of Qohelet, but in context the term seems to convey some sense of "restlessness, obsession, worry, and human inability to find enjoyment." ${ }^{53}$ Seow describes the term in Qohelet 1:13 and 3:10 as the failure of the "efforts of people to grasp-by wisdom-all that is happening in the world." 54 Murphy (based upon Zimmerli) describes the task as the "principle of questioning" and suggests that this is a God-given imposition. ${ }^{55}$ Kruger views the term as the commission that God gives "to human beings to investigate all that is done under heaven," 56 while Fox understands this as the "effort to understand what happens on earth," a task imposed by God yet doomed to failure. ${ }^{57}$ In reference to $3: 10$, Ogden, when

${ }^{53}$ VanGemeren, NIDOTTE, 452-53. This nominal term is found eight times in Qohelet (1:13; $2: 23,26 ; 3: 10 ; 4: 8 ; 5: 3,14$ [Heb 5:2, 13]; 8:16), and is unique to Qohelet in the Hebrew Bible. The term is derived from the verbal root $3, y$, to be troubled, occupied, or preoccupied. In Qohelet the term is defined by its context and relationship to the reality of human existence within the framework of הכל Its own etymology therefore has little impact on its usage in Qohelet's theological rhetoric.

\footnotetext{
${ }^{54}$ Seow, Ecclesiastes, 146.

${ }^{55}$ Murphy, Ecclesiastes, 13.

${ }^{56}$ Kruger, Qoheleth, 63.

${ }^{57}$ Fox, A Time to Tear Down, 171.
} 
asking, "what specifically is the "task'?," answers, "It is God-given, and in the present context presumably refers to the matter of living responsibly in a world of divine ordering ..."58 However, unlike most commentators, Ogden views God's involvement on imposing this burden as passive, while others see this as active and with a purpose (as opposed to a passive result). ${ }^{59}$

The ambiguity by which Qohelet uses this term should not come as any surprise. As with most terms in Qohelet, the connotation implied through ענין is best derived from context and the broader associations between motifs. In other words, the burden (or "עין") stems from man's fallen existence in a world described as הבל, it falls in line with the knowledge of one's own mortality, and it is derived from the recognition of wisdom's impotence in the face of a sovereign God who does as he pleases apart from the counsel of man. עניץ might be described as humanity's predetermined disposition to find something that can never be found, that is, $197,{ }^{60}$ or it may be a more purposeful ploy on the part of the creator to keep man from getting too full of himself (something akin to the Tower of Babel in Genesis 11). In either case, the only "purpose" by which the imposition of limitation is clearly marked in the text of Qohelet relates to a broader motif in the book, the fear of God (3:14), and the only way that such an understanding of its relationship to the imposition of limitation can be gained is to better understand the nature of time as it relates to Qohelet's theological anthopology.

\footnotetext{
${ }^{58}$ Ogden, Qoheleth, 54.

${ }^{59}$ Ibid, 55-56. Others not listed above include Lohfink ("He is already drawing the reader here towards God...") and Crenshaw ("The creator places a heavy yoke upon all human beings.") See Lohfink, Qoheleth, 47 and Crenshaw, Ecclesiastes, 73.

${ }^{60}$ Frydrych hints at this association between עביץ, and when he writes, "What humanity cannot achieve is by far more significant for Qoheleth then what it can, and his answer to the initial question 'what yitron?' is a resolute 'none!'; anything that he examines turns out to be הבל." See Frydrych, Living under the Sun, 152.
} 


\section{Time, Circumstance, and Probabilistic Wisdom}

Among the most enigmatic of Qohelet's well known contributions to theology and literature is the so-called "catalogue of times" (Qoh 3:1-8) and its subsequent commentary highlighting the implications of this poem's observations (3:9-15). Depending upon one's view of the time concept as described in the poem, Qohelet is either arguing the case for divine determinism, ${ }^{61}$ or he is questioning providential sensibilities in light of man's inability to comprehend the absurdity of events that occur outside of their appropriate time. In either case, one must concede that elsewhere Qohelet does argue for a certain degree of determinism in his theology of God, and equally so, he questions providential wisdom throughout the text with his repeated הבל judgments. ${ }^{62}$ While noting that either approach aligns with Qohelet's theology and general line of argument, it is nevertheless important to investigate with some precision Qohelet's insights on time and their relationship to God's sovereignty, the imposition of limitation upon mankind, and by extension, probabilistic wisdom and the fear of God.

It has already been argued that Qohelet's view of God's sovereignty is not of the kind best described as fatalism, but rather, it is a more nuanced variety that affirms divine control while commending the merits of wisdom's probability and humanity's possibility. Michael Fox, who in earlier works assumed a strong determinism when assessing the

\footnotetext{
${ }^{61}$ In this particular context, the case for determinism is argued through the affirmation of God's sovereignty over the time in which events occur. In other words, such "strong determinism" suggests that all acts and events are predetermined as to the moment in which they will occur.

${ }^{62}$ As noted in chapter two, within the range of meanings internal to the הבל symbol lies a set of connotations denoting the concept of "absurdity," "an affront to human reason," which by way of implication suggests a questioning of the providential wisdom of God over the function of the cosmos.
} 
"catalogue of times," later rescinded his view in favor of a softer determinism nuanced by his understanding of the definition and role of the concept. He writes of Qoh 3:1-8:

I now interpret this passage as presuming a less rigid sort of determinism. Qohelet does believe in divine control. God controls what will happen on the large scale, creating the world the way it is, and on the small scale he repeatedly and unpredictably intrudes and overrides human efforts. He makes man die at apparently arbitrary times. He radically circumscribes human freedom and effectuality. Nevertheless, Qohelet does not hold to a strict fatalism. God does not predetermine exactly what will happen and when. He has the power to do so but does not always use it. The Catalogue speaks about the right times, the circumstances when, in the proper course of events, something should happen or be done. But these are not the times when things will inevitably occur. ${ }^{63}$

The reason for Fox's change of opinion rests not only with his notion of the maל motif, but also due to a more precise exegetical understanding of the "time" (עת) concept in Qohelet. As with the English word "time," the Hebrew term ע can function in a number of ways, any of which may be designated as appropriate depending upon context and qualifying terms. ${ }^{64}$ In both English and in Hebrew, one can understand "time" in the temporal sense (as a location on the time-continuum) or in the substantive, conceptual sense (as defined by events and their configurations). The first sense (temporal time) may be defined by a time slot (winter time, that is, winter solstice to vernal equinox), while the second sense (substantive time) might be defined by the events that take place within a given or potential time period (the time to wake up in the morning, a good time to ski, or the right time to invest). Furthermore, one might speak of actual times (the rainy season) or appropriate times (the time to plant). ${ }^{65}$ Lexically, a variety of options exist as

\footnotetext{
${ }^{63}$ Fox, A Time to Tear Down, 197.

${ }^{64}$ Qohelet uses in in 3:1; however, does not appear to carry a distinctive meaning that contrasts with the use of 2 in the rest of the passage. See VanGemeren, NIDOTTE, vol. 1, 1114-115.

${ }^{65}$ For a more thorough treatment of the above, including examples and systematic categorization, see Fox, A Time to Tear Down, 194-96.
} 
to how the term might be used in the "catalogue of times," with all variety of nuances being evident throughout the Hebrew Bible. ${ }^{66}$ However, within Qohelet one finds a propensity for the substantive use of the term. For instance, Qoh 9:12 speaks of an עת which falls suddenly and unexpectedly upon a man (the focus being upon the event and not the moment in which it occurs on the time-continuum), while Qoh 10:17 speaks of the appropriateness of a time (the proper time and manner) for kings to eat. In Qoh 7:17c, one finds the rhetorical question "why die before your time (ת)?", a reference not to the date of one's death, but to the appropriateness of that date; in other words, not "when you die, but when you should die." 67

While some of the "times" listed in the catalogue of times might refer to temporal time ("a time to be born and a time to die" i.e., the date and time of one's birth and the date and time of one's death), there are others that are simply quite awkward when understood in this light ("a time to embrace and a time to refrain"). ${ }^{68}$ As a whole, the types of events described in the catalogue of times describe sets of circumstances in which binary pairings of opposed event-types function to describe a structural property of

\footnotetext{
${ }^{66}$ The nominative $\Omega$ is the most common word for the concept of time in the Hebrew Bible. In most cases the term is associated with specific events, designating the time in which an event takes place (rather than an abstract concept). A period of time in a calander day or year can be expressed by the word ("the time of the going down of the sun"; 2 Chron 18:34), or a more general described period ("times of trouble"; Ps 9:9; 10:1). In the same sense, the prophets often expressed the relationship between time and event through the phrase, "at that time" (Jer 4:11; 8:1; Isa 18:7; Zeph 3:19). The term can also designate the proper time for an event, the time when something should take place (Prov 15:23; Hos 10:12). In rare cases, the term is conceptual, such as in the reference to בכל ער, "all the time" (Lev 16:2; Ps 10:5). See Anthony Tomasino, NIDOTTE, 563-67.

${ }^{67} \mathrm{Ibid}, 203$. Fox here equates this sense of the term to the John Kennedy assassination. The nation mourned the death of John Kennedy because he died "before his time" in 1963. The emphasis is not on the date of his death, but on the fact that he died as a young man, before the appropriate age in which one should die.
}

${ }^{68}$ For further rationale behind why this opening pairing could be perceived as referring to events occurring at a point on the time-continuum, but should not, see Frydrych, Living under the Sun, 120-21. 
reality. ${ }^{69}$ When viewed in this manner rather than in the manner of specific events in the time-continuum, the binary pairings no longer take on the role of depicting God's deterministic choice of when events must take place. ${ }^{70}$ Rather, the substantive events listed in the catalogue take on the role of describing the appropriate "time" in which those events should occur, not necessarily describing when they occur (although Qohelet never doubts that they occur) ${ }^{71}$ Thus, the thematic emphasis in the catalogue is not to reaffirm the deterministic choice of God, but to drive the reader to understand that wisdom seeks an understanding of proper "times," and when in the jurisdiction of mankind, enables him to do this or that in its proper time.

However, one finds that man does not always have control over the times, even though he may understand the appropriate time for a matter to occur. ${ }^{72}$ And in step with the prominent role that the הבל judgment plays in the book, Qohelet laments that though

${ }^{69}$ Fox, A Time to Tear Down, 200.

${ }^{70}$ While it is obvious that Qohelet's observations in the time catalogue entail binary pairings, some have expounded in detail upon the meaning behind such pairings. Perhaps most compelling is the argument of equilibrium proposed by Tomas Frydrych. Reinforcing his equilibrium assessment of the key word Frydrych writes: "God designed the world in such a way that for every set of circumstances leading to some positive outcome, there is a corresponding set of circumstances producing a negative outcome and the negative and positive are in balance, maintaining an equilibrium which is neither positive nor negative, but simply neutral, or, in Qoheleth's own vocabulary, הבל. Qoheleth's concern in this poem is not when things happen but that they happen, and that they come to mutually annulling pairs." See Frydrych, Living under the Stu, 121-22.

71 The fact that these events occur fits in nicely with the chiastic parallelism between the catalogue of times (3:2-8) and the cyclical nature of events (1:4-9). The apparent chiasm is all the more obvious with the correspondence between the programmatic question in 1:3 and its repetition in $3: 9$ (the quest for yitron), thus forming an inclusio for the chiasm. Correspondence can also be observed between 1:13 and 3:10 (the imyan laid upon man) as well as 1:9 and 3:15a (reinforcing the cyclical nature of the world and of life), although precise structure begins to break down at this point. On the nature of chiasm, structure, and polarity in the opening chapters of Qohelet, see Fox, A Time to Tear Down, 200; Addison G. Wright, "The Riddle of the Sphinx," $C B Q 30$ (1968):313-34; and David A. Dorsey, The Literary Structure of the Old Testament, (Grand Rapids: Baker, 1999), 192-98.

${ }^{72}$ In other words, though he may know the right time in which it is appropriate for a man to die (at a ripe old age), he nevertheless does not have the power to see this through. 
God could make all things happen in their appropriate times, he does not always do so. ${ }^{73}$ On this vexing irony, Fox writes: "He sets the times man is to aim for, yet, paradoxically, he himself does not always act then. The 'times' such as Qohelet lists are not precisely God's times. They are not always coordinated with God's prior plans, and he must sometimes override them." $" 74$ Thus, as to man's perspective, the wise man will be cautious to consider the right time to do anything, yet he too must realize that wisdom necessitates an understanding that God is not "boxed in" by the "times." In a הבל world, God may override the "times," he may seemingly ignore an appropriate time, and he will never allow man full control over the "times." However, the wise man can and should be proactive in doing things "according to their times."

Here we find in the catalogue of times the confluence of so many of Qohelet's ideas: God's providential establishment of appropriate "times" reinforce the concept of "hevelness" in the world, even as seen in the paradox of events occurring outside of their appropriate times may seem to speak out against God's providence. Yet Qohelet knows that God is sovereign, and thus one is faced with the conundrum of events that occur at such "inappropriate" times. Even so, man knows the right times, and has some sense of how the universe should work, and thus he seeks to live out his life by way of probabilistic wisdom. Perhaps nowhere is this better illustrated in Qohelet than in his wisdom on risk and reward in 11:1-6. Man can only cover his bets and prepare for any event; although he may make wise decisions based on what should become, he must also plan on contingincies regarding what may become.

\footnotetext{
${ }^{73}$ Fox, A Time to Tear Down, 204.

${ }^{74}$ Ibid.
} 
This then is the essence of probabilistic wisdom, a type of wisdom fully aware of God's inscrutable sovereignty, the limits of man's control, and the sense of appropriate "times" in which things should happen. Furthermore, the world created and maintained by God is one that is "opaque to man's wisdom (3:11) and constrained by God's control of events (3:14)."75 Therefore, "whoever has the wisdom to recognize this will fear God and share the humility epitomized in the confession of the psalmist: 'My times are in your hand' (Ps 31:16)."

As we conclude our discussion of God's inscrutable sovereignty and the imposition of limitation upon mankind, a few thoughts are warranted in regards to the stated purpose in Qoh 3:14, "God does it so that men will revere him (NIV)." The "fear God" motif will be explored in greater detail in a later chapter, but as mentioned previously, this is the most explicitly stated purpose in the text behind why God limits man and lords his sovereignty over him. As a result of the fall, the constitution of man and the circumstances of life are such that he is limited in a multitude of ways, and these limitations are only heightened when set in comparison with God. The contrast between God and man is implied throughout the text, but perhaps nowhere as much as in $3: 14 \mathrm{a}$; everything that God does will endure forever, as opposed to the works and achievements of mankind. A wise man should fear God if for no other reason than that God demonstrates his sovereign superiority by default; the observations supporting this run throughout the text of Qohelet. However, it appears that Qohelet takes his "theological anthropology" one step further in 3:14 by suggesting that God intends for people to fear him. The relative conjunction " $w$ " in the concluding statement "[A]nd God does (this)

\footnotetext{
${ }^{75}$ Ibid, 213.

${ }^{76}$ Ibid.
} 
'שיראו' ('that they might fear') him (מלפי"י; lit., 'from his face')," functions to introduce a purpose clause. Although the grammar permits either purpose or result, ${ }^{77}$ the context seems to argue in favor of something intentional. This can be derived from the active participation of God having "given" (נתן) a "burden" (עין) on men (3:10), having "made" (עשה) everything beautiful in its time (3:11), and having "set" (נחן) eternity in their hearts $(3: 11) .{ }^{78}$ In context, God is actively and intentionally engaged in humbling man (3:10) and bringing him to a state of reverence (3:14). Thus, there is purpose in the imposition of limitation and an appropriate response for those who come to an awareness of the sovereign hand of the providential Creator. God intends that man fear him, and the wise man will do so with all due reverence. Nevertheless, such fear does not paralyze man; rather, as will be later argued, it invigorates him to live life to its fullest, even if he does not fully understand the sovereign rationale behind the circumstances that influence his situation. Indeed, the result of wisdom is in part the fear of God; God has purposed that it be so. But the pursuit of wisdom, the enjoyment of a vigorous life, and the fear of God stem not only from the recognition of God's sovereignty as heightened by the equally important recognition of man's limitations. It also stems from the most telling of man's limitations, his mortality. To this motif we now turn.

${ }^{77}$ See Gensenius, trans. Samuel Prideaux Tregelles, Hebrew and Chaldee Lexicon (Grand Rapids: Baker, 1979), 797 and Brown, Driver, Briggs, Hebrew and English Lexicon, 979-80.

${ }^{78}$ The three verbs cited above are Qal perfect $3 \mathrm{~ms}$, with God as the subject. 


\section{CHAPTER 6}

\section{THE INESCAPABLE DESTINY OF ALL MEN: THE INEVITABILITY OF DEATH MOTIF IN THE BOOK OF QOHELET}

In developing an Old Testament theology of death and the afterlife, one finds that the Old

Testament is frustratingly silent regarding what many consider to be the most pressing question for religious inquiry; what, if anything, exists beyond the grave? A survey of the Old Testament reveals that the prophets and wisdom teachers of antiquity are far more interested in preparing the follower of Yahweh for life in the present realm of the living than in revealing a clear theology and description of the afterlife. ${ }^{1}$ Old Testament theologies and the scholarly community are almost uniformly in agreement regarding the silence in the Old Testament regarding any theological or eschatological significance to death and dying. ${ }^{2}$ Mendenhall concurs with this assessment by stating:

Most of the scholarly world agrees that there is no concept of immortality or life after death in the Old Testament. The human body was shaped by God from the earth, and animated with the "breath of life" nefes hayyim (Gen 2:7-8). At death, the person becomes nefes met, literally, "a dead breath" (Numbers 6:6), and the

${ }^{1}$ The Old Testament stands in contrast with other ancient near eastern cultures and their obsession with the subject of death and the afterlife. Most notably one sees in contrast the Egyptian mortuary practices and their attendant texts. However, it is interesting to note that Egypt too has its own collection of skeptical texts calling into question assurances regarding the nature of the afterlife. With the tomb inscription of King Intef (Middle Kingdom) and the later Harper Songs from the New Kingdom, a new wave of skepticism cast doubt upon the traditional activities of Egyptian tomb building and its preparation for the afterlife. These Harper Songs are noted for thematic similarity to Qohelet's views on death and the afterlife, noting that humans cannot really know anything about the details of the afterlife, and that the best thing for a person to do is to enjoy life in the present. See M. Lichtheim, "The Songs of the Harpers," JNES 4 (1945): 178-212.

${ }^{2}$ Not only is this true in an absolute sense, it also rings true in a comparative relationship to other ANE cultures, even those in closest proximity to ancient Israel. Klaas Spronk notes that "compared to Canaanite religion Yahwism is remarkably silent with regard to the afterlife." See Klaas Spronk, Beatific Afterlife in Ancient Israel and in the Ancient Near East, (Kevelaer: Butzon und Bercker, 1986): 281. 
body returns to the dust whence it came. At the same time, when people die, they descend to Sheol, which can only be defined as the place where the dead are dead. The presumption is that the deceased are inert, lifeless, and engaging in no activity." ${ }^{3}$

However, this is not to say that the Old Testament is completely silent regarding death and dying. The Hebrew (Sheol) is found 65 times in the Old Testament, depicting the dwelling place of the dead (whether this refers to the simple grave or the underworld is a matter of considerable debate, but semantic flexibility is apparent from the various contexts in which the word is found), described as a place of gloom and deep darkness, and metaphorically speaking, an enemy to be avoided. ${ }^{4}$ In Sheol, all hope in future blessing ceases and there is no longer opportunity to express praise to the Lord. ${ }^{5}$ References to the surviving consciousness of the individual in Sheol are vague at best, and the notion of the enduring reality of the "soul" is difficult to maintain from the Old Testament alone. $^{6}$

In addition to the Sheol concept, the Hebrew Bible reflects upon death implicitly as it describes the ephemeral nature of human life. Human mortality is by default a reflection upon death, and the psalms and wisdom texts are consistent in expressing

\footnotetext{
${ }^{3}$ See George Mendenhall, "From Witcheraft to Justice: Death and Afterlife in the OT," in Death and Afterlife: Perspectives of World Religions, Hiroshi Obayashi, ed. (Westport, CT: Glenwood Press, 1992): 68.

${ }^{4}$ Eugene H. Merrill, "שw" in New International Dictionary of Old Testament Theology and Exegesis, ed. Willem A VanGemeren (Grand Rapids: Zondervan, 1997), 6-7. See Ps 30:9; 88:10-12; 141:7; Job 10:20-22; and 24:19. Perhaps the most helpful volume to date on the Old Testament theology of Sheol is Phillip S. Johnston, Shades of Sheol: Death and Afterlife in the Old Testament (Downers Grove, Illinois: Intervarsity, 2002).

${ }^{5}$ Shannon Burkes, Death in Qoheleth and Egyptian Biographies of the Late Period, (Atlanta: Society of Biblical Literature, 1999), 13.

${ }^{6}$ Ibid. See also Antonio R. Gualtieri, The Vulture and the Bull: Religious Responses to Death, (Lanham, MD: University Press of America, 1984), 82 and Robert Martin-Achard, From Death to Life, (Edinburgh and London: Oliver and Boyd, 1960), 17.
} 
human impermanence, often expressed through colorful imagery. ${ }^{7}$ Although human ephemerality renders death's grip inevitable, the Old Testament nevertheless describes God's power over death as a way of expressing his hand of salvation from present troubles. Thus death, while a feared enemy, can be temporarily kept at bay through the defending presence of God. ${ }^{8}$ In the Old Testament, the role of God in reference to man's mortality is to provide salvation in the present realm, not to grant life everlasting in a future, heavenly realm.

Wisdom, as with devotion to Yahweh, also protects the life of its practitioner, and spares one's life from premature death. Hebrew wisdom literature never suggests that the wise will not die, but does commit to the idea that wisdom will lengthen the years of one's life. Burke elaborates thus: "Like the passages in the psalms where God will save the afflicted from Sheol, the point here is not that the wise person will never die, but that wisdom leads one into the kind of life which preserves one from a bad, early death, and into a long, full, and prosperous length of days." ${ }^{9}$ The emphasis in the Hebrew cult, its prophetic history, and its wisdom literature was on the qualitative life as lived in the present, first for the nation, and secondarily for the individual. ${ }^{10}$ This "corporate

\footnotetext{
${ }^{7}$ Burkes, Death in Qoheleth, 12. Burkes notes that "this impermanence is often expressed in the same terms: like a shadow, a dream, a passing cloud, an empty breath, the dust, withering grass, fading flowers, a sigh." Burkes lists the following references in support of human ephemerality in the Old Testament: Ps 39:4-6, 11; 49:10-15; 89:47-48; 90:3-6, 9-10; 103:13-16; 104:29; 144:3-4; 146: 3-4; Job 7:910; Job 14:1-5; and Job 34:14-15. See Burkes, Death in Qoheleth, 11.

${ }^{8}$ Ibid, 14-15. Burkes references Ps 16:9-11a; 30:3; 33:18-19; 36:9; and 68:19-20. See also Nicholas J. Tromp, Primitive Conceptions of Death and the Nether World in the Old Testament (Rome: Pontifical Biblical Institute, 1969) and Johnston, Shades of Sheol for a more thorough analysis of death as enemy and God as the defender of life.

${ }^{9}$ Burkes, Death in Qoheleth, 15-16. See also Prov 8:35-36; 14:27; 15:24; and 21:16.

${ }^{10}$ Quoting John J. Collins, "The Root of Immortality: Death in the Context of Jewish Wisdom," HTR 71 (1978):185, Burkes writes, "Moreover, if one lives properly and under God's law, then a ripe old age and a peaceful death are to be expected, and appreciated. The book of Proverbs shows how death can
} 
personality" was demonstrated in the Hebrew Bible's emphasis upon the survival of one's offspring, name, and nation as the answer given to the universal problem of death. ${ }^{11}$ Little is said in the Hebrew Bible of the afterlife, and the "tradition" reveals little interest in seeking to answer death through a revealed or speculative notion of the afterlife. ${ }^{12}$ Despite the general silence of the Old Testament in regard to this topic, the inevitability of death hovers as an overriding spectre constantly looming on the horizon of Qohelet's thoughts and reflections. ${ }^{13}$ Some have suggested that "death" is seated at the very core of Qohelet's message, and even if death is understood as subsidiary to the programmatic proclamation of life as הבל, one must nevertheless recognize death as one of the culprits behind the הבל indictment. ${ }^{14}$ Throughout the bulk of Old Testament

be comfortably incorporated into an orderly system. 'Because the qualitative life of wisdom prevails unambiguously over the qualitative death of the fool, the fact that every human life ends in death seems less important." See Burkes, Death in Qoheleth, 32.

${ }^{11}$ Burkes writes, "The Israelites had practically no notion of an afterlife for the individual because of their finely honed sense of the people's survival in general under God's guidance; community continuity provided comfort in the face of death." Thus, it was this corporate identity that became the Israelite's answer to the problem of death, and there was little need in light of this to answer death in a theological or personally eschatological manner. See Burkes, Death in Qoheleth, 27, 31.

${ }^{12}$ Burkes sites Daniel 12:2-3 as "the only indisputable affirmation of an afterlife in the Hebrew Bible," but in doing so, also relegates the authorship of Daniel to a very late date (167-163 B.C.E.), so late in fact that Daniel would be better placed in theological context alongside apocryphal, inter-testamental literature. See Burkes, Death in Qoheleth, 18, 83 and Collins, Daniel (Minneapolis: Fortress Press, 1993): 394. Others argue that Isaiah $26: 19$ is a clear reference to the resurrection, but this too may be veiled in imagery depicting Israel's renewal after exile. Another line of argument suggests that the laws against necromancy imply a belief in the afterlife by followers of Yahweh, although a variety of options are available that explain these laws in light of pagan influence and prohibitions against the laws and practices of pagan nations. See Burkes, Death in Qoheleth, 18-25; Collins, Daniel, 395; Spronk, Beatific Afterlife, 244-57; and Elizabeth Bloch-Smith. Judahite Burial Practices and Beliefs about the Dead (Sheffield: JSOT, 1992): 146-51, 222-24.

\footnotetext{
${ }^{13}$ Fox reflects a general consensus when he writes, "Qoheleth reveals an obsession with death unparalleled in biblical literature." See Fox, Contradictions, 294.

${ }^{14}$ Burkes suggests that the organization of the book of Qohelet around the inevitability of death motif implies that death is "core" to Qohelet's message. She too understands תבל as primarily connoting the transience of life, and thus functioning too heighten the inevitability of death (Burkes, Death in Qoheleth, 48). For those who view הבל in like manner, see Fredericks, Coping with Transience, and Farmer, Who Knows What Is Good?
} 
literature, "symbolic immortalities" function as the traditional answer to the problem of death. ${ }^{15}$ Qohelet turns such tradition on its head, functioning as the canonical transition from traditional solutions to the problem of death to an implied theological solution. ${ }^{16}$ While most of the Old Testament deals with death as a side note to more pressing matters of national and cultic interest, in Qohelet the inevitability of death rises to thematic prominence as a problem that is not adequately dealt with by traditional answers, thus paving the way for an eschatological solution as the problem. ${ }^{17}$ The extent of Qohelet's movement, however, is an open matter of debate. ${ }^{18}$

The book of Qohelet is an enigmatic book about enigmatic things, with a message that has proven to be quite "enigmatic" for scholars and lay readers alike. Thus it is not surprising that commentators are quite divided over Qohelet's view of death, especially pertaining to the expectancy of judgment in Qohelet's view of the afterlife. ${ }^{19}$ For many

\footnotetext{
${ }^{15}$ Neatly summarizing the traditional Hebrew manner of coping with death, Burkes writes, "The Symbolic immortalities offered elsewhere in the Bible, the memory and endurance of a good name, survival through one's children and people, even the qualitative good life that negates the 'death' of folly and unrighteousness, fail utterly in Qoheleth's opinion." See Burkes, Death in Qoheleth, 75.

${ }^{16}$ Ibid, 33 .

${ }^{17}$ Burkes writes, "The societies represented in the biblical texts appear to have integrated death into the religious system in an unobtrusive, if sometimes melancholy, way. The one exception to this observation is the book of Qoheleth." See Burkes, Death in Qoheleth, 10.

${ }^{18}$ If understood diachronically, one is impressed with the movement from the Old Testament view of death and the afterlife to that of the New Testament's more personal, eschatological approach. Between these periods of revelation history lies the inter-testamental period and its literature, which suggests a certain degree of movement, effectively bridging the gap between the testaments on this topic. Some have suggested that Qohelet is a predecessor to the apocryphal writers, and ultimately, to the New Testament writers. Such movement, and its corresponding placement in revelation history, does depend upon (or at least implies) a post-exilic date (but not necessarily a Hellenistic context) for the origin of the book of Qohelet. See Farmer, Who Know's what is Good?, 203-06 and Burkes, Death in Qoheleth, 81-119. Note especially Burkes opening remarks on page 81 , "Qoheleth is not the only Jewish thinker in this period who is troubled by death, as it turns out, though one must go outside the canon to realize that he is a forerunner of an emerging trend."
}

${ }^{19}$ Antoon Schoors begins his article "Koheleth: A Perspective of Life after Death?" by stating that a great diversity of opinion exists in general approaches to the book of Qohelet, and then arguing in turn 
commentators, Qohelet's reflections reveal a belief devoid of future expectation. Tremper Longman comments, "As far as Qohelet knew for certain, death was the end of the story," and, "Qohelet has no hope that things will be 'put right' after death." ${ }^{20}$ In keeping with his decidedly negative approach to Qohelet, it is no surprise that Crenshaw views Qohelet's theology of death and the afterlife in dire terms. He writes, "Qohelet saw no basis for optimism about the next life, either in its Hebraic expression, the resurrection of the body, or in its Greek expression, the immortality of the soul. For Qohelet, Sheol was a place of nonbeing." 21 Frydrych nuances this view by stating, "The deliberation about what happens to the human and animal ruah at the point of death reflects familiarity with a belief in a meaningful afterlife, but it is not something to which Qoheleth himself appears to adhere. ${ }^{, 22}$ Likewise Burkes, while affirming that Qohelet wrote (or lived) within the context of a society entertaining ideas of the afterlife, nevertheless concludes that in Qohelet's view "there is no hope of restitution after death.",23

Still others take a more agnostic view towards Qohelet and his expectations of an existence beyond the grave. For instance, Roland Murphy understands Qohelet's view as ignorant of an existence beyond the grave, but he is quick to buttress this by stating that Qohelet was clearly not affirming annihilation. He writes:

After death, there was nothing in his view. However, it may be going too far to say that he held to a view of 'total Extinction'. Such a conclusion rests on the

that this is also the case "with respect to Koheleth's views on death and the afterlife." See Antoon Schoors "Koheleth: A Perspective of Life after Death?," ETL 61 (1985): 295

${ }^{20}$ Longman, Ecclesiastes, 34.

${ }^{21}$ Crenshaw, Ecclesiastes, 163.

${ }^{22}$ Frydrych, Living under the Sun, 112-13.

${ }^{23}$ Burkes, Death in Qoheleth, 78-80. 
Western notion of the human composite, which was far from Qohelet's mind. His words may suggest a resolution of the human being into nothingness, even annihilation, only because he is using the images of Gen 2:7 - the breath of life returns to God who gave it, and the body obviously corrupts in the dust. One should not read (Greek) philosophical concepts into such a phenomenological description. ${ }^{24}$

Murphy is quite correct in maintaining a balanced perspective in light of the "under the sun" perspective through which Qohelet reflects upon life and death. Although most commentators acknowledge that Qohelet's words on death affirm some sense of annihilation, too few recognize that his use of annihilation vocabulary is representative of an "under the sun" perspective, seeing life as it appears from a "horizontal perspective," not necessarily viewing life as God would from an absolute, heavenly perspective. ${ }^{25} \mathrm{In}$ any case, on the matter of death and theology, it would be somewhat dangerous to read too much theology into the words of Qohelet. A theological treatise on death was not his purpose in any portion of the book; rather, his purpose was to determine how a wise man might best live in light of death's looming spectre.

Even when not giving full recognition to the issue of phenomenological perspective, there are some who nevertheless view Qohelet as quite the innovator, pressing the canonical treatment of death and the afterlife forward into the intertestamental period and beyond to the more fully developed theology of the New

\footnotetext{
${ }^{24}$ Murphy, Ecclesiastes, Ixvii.

${ }^{25}$ Surprisingly, few commentators actually do justice to the theological context from which Qohelet wrote. For starters, very few authors correlate the "under the sun" perspective with Qohelet's view of death and the afterlife. Furthermore, few commentators take into consideration that Qohelet's work is clearly of a wisdom genre, thus emphasizing the pragmatic lessons that influence the way a person lives, not so much what they believe. Lastly, Qohelet wrote during a time when the full revelation of God was yet to be revealed, and thus, while inspired, the text of Qohelet may nevertheless reveal a comparatively limited view of the afterlife and the judgments to come.
} 
Testament. ${ }^{26}$ For these commentators, Qohelet, while not revealing a clear picture of the afterlife, moves beyond most of the Old Testament by hinting at some form of postmortem judgment, even if death is the great equalizer of justice so far as Qohelet's "under the sun" perspective can tell. ${ }^{27}$ For instance, Kathleen Farmer understands Qohelet's musings as an avenue to advance the Old Testament perspective beyond the traditional retribution theology of the Pentateuch and the prophets. She writes, "There are some indications that Qohelet and his audience may be considering new ways to reinterpret the old traditions. For instance, the frequent use of the term 'under the sun' in this book seems to indicate that either the audience or the speaker had begun to speculate about life after death as a way of resolving the dissonance between traditional retributive expectations and observed reality." 28 Regarding the nature of the judgment texts in

\footnotetext{
${ }^{26}$ Mendenhall is quite typical of critical scholarship in attributing a late date to Ecclesiastes. In doing so, he recognizes the Eccl 12:7 reference as "very late," and as an advancement towards a resurrection theology that finds its only OT canonical parallel in Daniel 12:2, also a "very late" text. He states, "Some 400 years after the destruction of Jerusalem we have in Daniel 12:2 a clear statement affirming the resurrection of the dead, and it is combined with the affirmation of reward and punishment meted out after the resurrection (Mendenhall, Death and Afterlife, 79)." This is testimony in his mind of the transitory process of ideological and theological change that occurred during the Hellenistic period reward and punishment continued as an essential element in Hebrew thought, but was now placed in an apocalyptic/eschatological context rather than a covenantal/temporal one. This shift is seen also in Qohelet's theology of death and the afterlife.

${ }^{27}$ The advancement of an Old Testament theology of the afterlife in Qohelet's thought can also be measured from the anthropological perspective. Lloyd Bailey Sr. traces the anthropological development of the human being in the Old Testament by noting that "Human beings, as depicted in Israel's canonical creation stories (Gen 2-3), are not complex creatures who are composed of a number of constituent elements. Such concepts as body, soul, and spirit, familiar to us from later anthropologies, are entirely alien to the stories." However, as with other critical scholars who date Qohelet as a late work, he sees a point of departure in Qohelet's thought from that of the rest of the Old Testament. Bailey states, "Indeed, it is only in the relatively late book of Qohelet that we find raised a question of the distinctiveness of the human ruah - a question which the author answers in a skeptical-to-negative mode." It is worth noting here that Job 34:14 and Eccl 12:7 are the only scriptural passages denoting the idea that a "life-force" returns to God at death. The idea here is that only in these few references does the OT seek to differentiate the human anthropology from that of other living creatures, and that for the purposes of this study, such an observation constitutes an "advancement" in theological development, courtesy of Qohelet. See Lloyd Bailey Sr., Biblical Perspectives on Death (Philadelphia: Fortress Press, 1979), 41-45.

${ }^{28}$ Farmer, Who Knows What is Good?, 150.
} 
Qohelet $(3: 17 ; 8: 12 ; 12: 14)$, Farmer even suggests that these expectations of God's judgment infer a judgment that takes place beyond the grave, even though Qohelet fails to explicitly contextualize these texts into the afterlife. She writes, "However, Qohelet does not deny the possibility that God's judgment might take place somewhere outside of human experience. In fact there are several passages in Ecclesiastes which hint at such a belief: 'Though a sinner does evil a hundred times and prolongs his life, yet I know that it will be well with those who fear God, because they fear before him; but it will not be well with the wicked ...' (8:12-13; cf. 11:9; 3:17).,29

Farmer is not alone in finding a plausible option in personal, eschatological retribution. Ogden, while avoiding dogmatic statements on the afterlife not yet warranted by the text of Qohelet, nevertheless sees in Qohelet "a clear note of hope" for restitution after death. ${ }^{30}$ This "clear note of hope," while only implied, is rendered plausible by the consistent thread of "zwar/aber" reflection on the question of injustice and divine retribution throughout the text. While one might hope for justice in the present, and while wisdom would undoubtedly advise righteous living for the present $(8: 12-13)$, there is a certain hint of expectation that divine judgment will be left to future experience $(3: 17$; $11: 9 ; 12: 13-14)$, even if the present experience of inequity finds its crescendo in the grave. $^{31}$

${ }^{29}$ Ibid, 205-06. Referring to these texts, Farmer writes, "These expressions seem to me to imply that the speaker thinks a distinction can be made between what happens in human experience (under the sun) and what happens elsewhere. Thus, I would suggest that both Qohelet and his audience share an interest in the question of the existence of some form of the afterlife." See Farmer, Who Knows what is Good?, 206.

${ }^{30}$ Ogden, Qoheleth, 63.

${ }^{31}$ Interestingly enough, while Burkes suggests a degree of theological advancement in Qohelet that falls in line with extra-biblical inter-testamental literature and culture ("[Qoheleth] is the forerunner of an emerging trend"), she nevertheless finds in Qohelet no solution to the present experience of injustice. 
The essence of this chapter is to survey the "inevitability of death" motif within Qohelet, with the goal to ascertain Qohelet's theology of death and the afterlife, along with an assessment of how this motif plays into the greater message of the book. As the previous paragraphs have displayed, there is little agreement as to whether or not Qohelet constitutes an advancement in Old Testament theology regarding death and the afterlife, just as there is little agreement regarding the place and position of this motif in Qohelet's overall line of argument. For many, the whole notion of an afterlife in Qohelet is preposterous, running counter to the very emphasis that Qohelet place's on death's finality. For instance, Seow writes of Qohelet's theology, "Immortality of any sort is impossible, for death is the fate of every mortal. Nothing that human beings may possess-wisdom, pleasure, success, progeny-can change that fact." ${ }^{, 32}$ And although Murphy on one hand conveys Qohelet as an agnostic in his theology of death and the afterlife, he plainly states elsewhere that "[I]t is abundantly clear that Qohelet does not hold out any hope for life after death. ${ }^{, 33}$ But, as previously noted, the motif of the inevitability of death is far more complex than these negative assessments may imply. Qohelet is not a nihilist whose ponderings lead to despair. Rather, his reflections on death provide a necessary sobriety that enables the wise reader to move forward beyond despair to a renewed vigor and joy for life. ${ }^{34}$ Commentators such as Iain Provan wisely recognize

Rather, Qohelet brings the problem to light, while the apocalypses (including Daniel, which she dates at 167-163B. C. E.) "neatly neutralize the problem which faces Qoheleth, that his eyes are giving him bleak data and bleaker conclusions." See Burkes, Death in Qoheleth, 81, 83, 88.

${ }^{32}$ Seow, Ecclesiastes, 48.

${ }^{33}$ Murphy, lxviii.

${ }^{34}$ Eunny P. Lee makes the brilliant observation that joy in life can only be fully appreciated in light of its own relationship to transience; a recognition of the fleeting nature of a life that is bounded by death. She writes: "Finally, it (joy) takes place with the specter of death ever looming in the near horizon. 
this relationship between death and life in Qohelet: "It is the reality of death that makes rational the way of life that Qohelet commends to all his readers, with its focus on living each moment of life joyfully before God rather than on the pursuit of wisdom, wealth, or any other human end that comes under the heading "chasing after the wind" $(1: 14,17$, and throughout the book).",35

Although a verse by verse survey of the death related references in Qohelet would indeed be profitable, perhaps a better route to take is to survey the various principles on death implied throughout Qohelet, and through such a survey, deal more specifically with certain key texts representative of each principle. ${ }^{36}$ While most treatments of the death and dying motif in Qohelet tend to focus on the allegory/metaphor of 12:1-7, ${ }^{37}$ a simple scan of the book will quickly reveal that the motif is far more pervasive than this final passage might suggest. Nearly every chapter of the book contains at least a few implicit references to death and dying, and usually the references are more explicit than implicit. ${ }^{38}$ At times these references are positive $(4: 2 ; 7: 1-2)$, and others are clearly negative $(9: 3-6)$, making an overall assessment all the more difficult. Some references are couched in the

The window of opportunity for enjoyment is small because, as Qohelet frequently reminds his reader, life is bounded by death. Enjoyment, like all things under the sun, is ultimately hebel." (Lee, Vitality, 129)

${ }^{35}$ Provan, Ecclesiastes/Song of Songs, 39.

${ }^{36}$ The following approach is an adaptation of Barry C. Davis, "Death, An Impetus for Life," BibSac 148 (1991): 298-318.

${ }^{37}$ Although most commentaries provide a treatment on this passage, significant and helpful articles on Qoh 12:1-8 include Davis, "Death, an Impetus for Life," Michael Leahy, "The Meaning of Ecclesiastes 12:1-5," ITQ 19 (1952): 297-300 and Michael V. Fox, "Aging and Death in Qohelet 12," JSOT 42 (1988): 55-77.

${ }^{38}$ Although every reference to the term inevitability of death, Qohelet is often more explicit in his allusions to death and dying. The following references constitute a survey on the motif in Ecclesiastes: $2: 14-16 ; 3: 2,19-22 ; 4: 1-3 ; 5: 15-16 ; 6: 3-4,6$; $7: 1-2,4,17,26 ; 8: 8,10,12-13 ; 9: 1-12 ; 11: 7-10 ; 12: 1-7$. Only chapters one and ten are without explicit reference to this motif. 
genre of proverb, while others constitute reflection speeches and the like. The one consistent testimony in every reference, however, is that death is coming just as surely as the cycles of life will continue forward in time $(1: 4-11){ }^{39}$

\section{Principles on Death and the Afterlife in Qohelet}

Principle One: All die, regardless of one's ability and status in life (2:14-16; 3:19-22;

$5: 10-15 ; 9: 2$ ). Although the conclusion is self evident, Qohelet must wrestle with the observation that death is the great equalizer of all mankind, whether he is wise or foolish (2:14-16), rich or poor (5:10-15), righteous or wicked, good or bad, clean or unclean, pious or irreverent $(9: 2) .{ }^{40}$ It is of no small consequence for Qohelet that he observes a striking lack of distinction at the grave. Burkes writes, "[Death] eradicates all distinctions of good and evil, wise and foolish, rich and poor, young and old, human and animal, and all others that can be imagined." A1 And thus one of the greatest challenges to traditional wisdom lies at the heart of Qohelet's reflections on life and the pursuit of "under the sun"; whatever man may do, and however he may live, life is always lived under the shadow of man's common fate in death. ${ }^{42}$

In the OT theology of retribution, a breach of covenant obligations was tantamount to treason; therefore the inevitable sentence of such treason was death.

${ }^{39}$ Burkes writes, "The reader cannot help but feel that the opening (1:2-11) and the close (12:1-8) of the book are not accidental (Burkes, 48)" and "The beginning and conclusion of the book neatly fit together, and bring the reader to the understanding ... death in chapter 12 is the full expression of the hevel that begins chapter 1 (Burkes, Death in Qohelet, 59)." For a detailed discussion on the correlation and structural intention between Qoh 1:2-11 and 12:1-8, see Burkes, Death in Qohelet, 48-54, 59.

${ }^{40}$ On the result that these observations made by Qohelet have on his demeanor, Schoors writes, "... so is this equality in death one of the facts that bring Koheleth to his radical aporia." See Schoors, "A Perspective of Life after Death?" 298.

\footnotetext{
${ }^{41}$ Burkes, Death in Qoheleth, 71.

${ }^{42}$ Graham Ogden, "Qoheleth IX: 1-16," VT 32 (1982): 158-69.
} 
Qohelet, however, observed that death was no respecter of person-death afflicted the

faithful as well as the unfaithful. No longer could death be seen as retribution or punishment-it was the inevitable fate of all humanity. ${ }^{43}$ Such observations are not limited to the moral or social realm; in the context of death, Qohelet even sees a lack of distinction between man and beast, at least as viewed from an "under the sun" perspective (3:19-22). ${ }^{44}$ However, with all of the above understood, Qohelet does not dismiss the advantages that wisdom may have over folly, or even the advantage that man may have over beast, but none of these advantages are sufficient to overcome the great equalizer that is death. ${ }^{45}$

Principle Two: Death Can Be A Foil Against Which the Quality of Life Can Be Measured $(4: 1-3 ; 6: 3-6)$. Israel's view towards death in the OT cannot be said to be simply negative or positive-there are times in which death is portrayed in a negative light and other contexts where death is portrayed in a positive light. ${ }^{46}$ It can be said that

\footnotetext{
${ }^{43}$ Mendenhall, Death and Afterlife, 77.
}

${ }^{44}$ It should be noted that considerable debate surrounds the question as to whether or not Qohelet saw any distinction between the postmortem existence of the animal and that of the human being. Some view Qohelet's question in 3:21 as rhetorical, with the question only later being answered in 12:7. For instance, J. Barton Payne writes, "Near the beginning of his book of Ecclesiastes, Solomon asked his readers, "Who knoweth the spirit of a man, whether it goeth upward and the spirit of the beast, whether it goeth downward to the earth?' $(3: 21)$. But later he provided the answer to his own question by affirming, 'The dust returneth to the earth as it was, and the spirit returneth unto God who gave it' (12:7)." However, others question whether or not Qohelet answers this question in the affirmative, or even if 12:7 ought to be considered original to the same author as 3:21. See J. Barton Payne, Theology of the Older Testament (Grand Rapids: Zondervan, 1962): 453.

${ }^{45}$ Although Qohelet would undoubtedly affirm substantial distinctions between man and beast in the order of God's creation, his point in 3:19-22 is not in any case to reflect upon these distinctions in an anthropological manner. Rather, he is focused upon the dehumanizing effect that death has on all mortal creatures, the highest of which is man. Burkes concludes her treatment of the death motif in Qohelet by stating, "Death is, in sum, ultimately dehumanizing in every sense: literally, because it undoes the components of existence, and metaphorically, because it makes humans no different from any other form of life." See Burkes, Death in Qoheleth, 71.

${ }^{46}$ For the most comprehensive treatment on death and its positive, negative, and neutral references in the Old Testament, see Philip S. Johnston, Shades of Sheol. 
“Israel's canonical literature may be described as 'mortality-accepting," but the context in which death is experienced determines whether it is to be viewed as positive or as negative. ${ }^{47}$ Although Qohelet is not overly concerned with the timing of death as a sign of favor and thus satisfaction, he does wrestle with death as a foil against which to compare the value of a life not well lived. For instance, in observing the state of the oppressed, Qohelet remarks that death (or non-existence) constitutes a better state of reality than life for those for whom living is synonymous with suffering $(4: 1-3)$. For those who cannot enjoy life, Qohelet states that a "stillborn child" is better off than he (6:3-6). ${ }^{48}$ Some see the above statements as indication that Qohelet's view towards life and death is such that death has rendered life utterly without value, and thus his essential emphasis is to esteem death over life. This is the view of James Crenshaw, whose approach to Qohelet is thoroughly negative, with very little positive value assessed to the book. ${ }^{49}$ In an article written specifically to address the motif of death in Ecclesiastes, Crenshaw understands Qohelet's affirmation of death in limited contexts to be representative of his view as a whole when he states, "Life devoid of equity, both human and divine, is hollow mockery. In such situations, death's lure can hardly be resisted." ${ }^{50}$ However, the emphasis in Qohelet's thought is not to discount the value or vitality of life, but to simply state (perhaps through hyperbole?) that a life of suffering, or a life where goods cannot be

\footnotetext{
${ }^{47}$ Bailey, Biblical Perspectives, 54.

${ }^{48}$ Commenting on Qoh 6:1-5, Burkes states that "an unusually lengthy life is not the solution to Qoheleth's problem...quality of life is as important as quantity." See Burkes, Death in Qoheleth, 66.

${ }^{49}$ Crenshaw, Ecclesiastes.

${ }^{50}$ See James L. Crenshaw in "The Shadow of Death in Qohelet," 205-216 in Israelite Wisdom: Theological and Literary Essays in Honor of Samuel Terrien, ed. By John G. Gammie (New York: Union Theological Seminary, 1978): 207.
} 
enjoyed, is simply no way to live the life that God has intended for the wise to enjoy as a gift.

Principle Three: The Timing of One's Death Is Ultimately Determined By God $(3: 2 ; 7: 14-18 ; 8: 7-8,12-13 ; 9: 11-12)$. Although Qohelet is clearly occupied by the enigmatic nature of God's sovereign hand, it is in the realm of death that his angst is so forthright and obvious. As Crenshaw states, "The arbitrariness of death troubles Qohelet more than anything else. Qohelet denies any pattern at all in death's timing and choice of victims." ${ }^{51}$ Longman concurs in his own assessment of Qohelet's theology of death: "As we read his reflections, we are struck by two inescapable facts of human existence that are the source of his anguish: (1) death and (2) the inability to control and know the appropriate time to do anything." 52

There is something intrinsic within humanity that seeks to control all aspects of life, and ironically, there is no area where this is more true than in the timing of one's own death. Although one's own decisions may hasten or delay the day of one's death, man certainly has no guarantee of control in this realm; it is ultimately determined by God $(3: 2 ; 9: 11-12) .{ }^{53}$ Such a recognition of God's sovereignty in the face of death caused Qohelet considerable angst rather than comfort. For an ancient wisdom sage, the goal in "practicing" wisdom was to learn by which principles a man may prosper and even

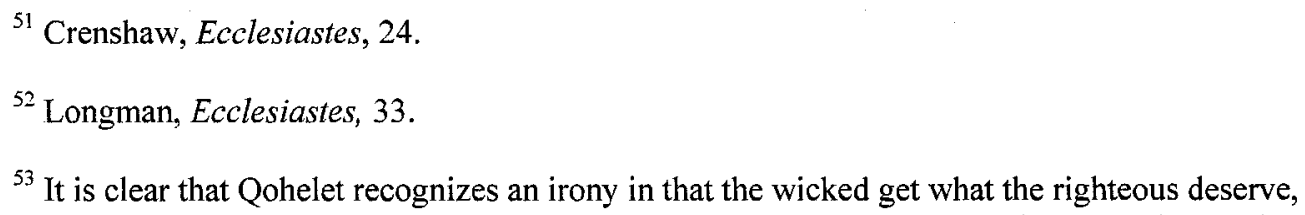

${ }^{53}$ It is clear that Qohelet recognizes an irony in that the wicked get what the righteous deserve, and the righteous get what the wicked deserve, yet he still acknowledges that the wise man will take heed to not allow anything to bring about a premature death, including wickedness (he has evidently not abandoned retribution theology altogether (7:16-18;8:12-14). By analogy, Qohelet could conceivably observe that a fat man lives to be 85 , and a very fit tri-athelete dies of cancer at 30 . He would determine that this too is הבל a seeming injustice that cannot be controlled by man. Nevertheless, Qohelet would advise the wise man to eat healthy and stay fit-why should he "tempt fate" and die before his time? 
lengthen his life-yet for Qohelet, wisdom was found wanting in the face of a sovereign God. ${ }^{54}$ Man could not by his wisdom gain exception from the inevitable verdict of death. Moreover, he could not by wisdom even guarantee any sure advantage in the timing of one's own death. ${ }^{55}$

Rather than leading to existential hedonism, Qohelet saw in time, chance, and death the ultimate manifestation of the distinction between God and man (3:11-14). Thomas Kruger acknowledges that such a distinction actually represents more than a constitutive separation-it is the manifestation of the judgment of God. He states, "By contrast, the contingency of time, fate, and chance, as well as death, represent the judgment of God over human beings-a judgment that ultimately all people meet in like manner, since none of them is completely innocent. ${ }^{, 56}$ William Brown likewise sees in death the judgment of God as dictated through time and chance. For Brown, time and chance function as a way to keep man beneath and separate from the divine certainty inherent within the mind and activity of God. He explains this in light of Qohelet's theology of death:

Yet for Qohelet death denotes far more than physical extinction. It is the script of incertitude around which all of life is written. The foil of human existence, death denotes anything that contravenes human plans and activities. Indiscriminate by nature, death is the certitude of uncertainty, the impenetrable veil that at once

\footnotetext{
${ }^{54}$ Regarding God's inscrutable sovereignty over the timing and manner of each man's death, Burkes writes, "Injustice, human limitation, and God's inscrutability are all sore trials to bear, but the disquiet they arouse finds its highest expression in the ultimate injustice, the consummate limitation, the token of God's inscrutability par excellence: death." See Burkes, Death in Qoheleth, 74.

${ }^{55}$ Here too it is worth noting the tension and balance in Qohelet's reflections and wisdom, for he does state that wisdom, like money, is a shelter, "but the advantage of knowledge is this: that wisdom preserves the life of its possessor (7:12)."

${ }^{56}$ Kruger, Qoheleth, 2.
} 
conceals and seals human fate. Death, in short, crowns the hegemony of chance, and retribution has no place in its kingdom (see 9:11-12). ${ }^{57}$

A similar approach to this distinction is taken by Provan, although without the nuanced emphasis on the judgment of God. Concerning death, Provan states, "Death is, in our world as in Qohelet's, the ultimate reality of life that demonstrates the universe cannot be "handled" by human beings at all." 58 Such a recognition flew in the face of everything that ancient wisdom stood for; if wisdom could not "handle" man's affairs in the universe, then what power did man have if any at all?

Wisdom could do more than simply teach a person how to excel in life. It also had a theological dynamic wherein a man could come to acknowledge his place before an Almighty God. This relationship between man and God was viewed by Qohelet, and I would suggest, by wisdom as well, to be one in which man is utterly set apart from God. However, it was not just an acknowledgment of power and might, or sovereign control over daily happenstance that brought Qohelet to such a conclusion. It was also Qohelet's reflections on the inevitable, unpredictable, and indeed "הבמל" nature of death that brought him to the point of awe. ${ }^{59}$ As Provan states, "Death, in particular, mocks all attempts at elevation to divinity and the refusal to be mortal and human. ${ }^{, 60}$ The same kind of theology that drove Isaiah to proclaim judgment against the King of Babylon in Isaiah 14:12-15 is rooted in the wisdom of Qohelet's view of death and deity. Or, as Qohelet

\footnotetext{
${ }^{57}$ Brown, Ecclesiastes, 122.

${ }^{58}$ Provan, Proverbs/Ecclesiastes, 41.

${ }^{59}$ Regarding the relationship between death and the key word הבל, Burkes writes, "[Death] is this ultimate hevel which embraces all the other manifestations of hevel and expresses life's overarching irrationality." See Burkes, Death in Qoheleth, 48.

${ }^{60}$ Provan, Proverbs/Ecclesiastes, 41.
} 
would say, "I know that everything God does will endure forever" (3:14a), (as opposed to man, a distinction so clearly seen in mortality). "God does it so that men will revere him $(3: 14 c) . "$

Principle Four: An Acknowledgment of the Inevitability of Death Will Lead the Wise to Pursue the Enjoyment of Life $(2: 24-25 ; 3: 12-13 ; 3: 22 ; 5: 18-20 ; 7: 4 ; 8: 15 ; 9: 7-$ $10 ; 11: 7-10)$. Qohelet is quick to advise the wise person to live soberly and carefully all the while doing so in anticipation of the reality of death (7:4). However, when one surveys the seven "enjoy life" conclusions found throughout Qohelet, one finds that the enjoyment of life is always commended in clear view of the inevitability of death. ${ }^{61}$ Concerning the injunction to enjoy life in light of death's looming spectre, Seow writes, "Enjoyment is possible only when people accept that God has made the world just so and that mortals have been given a heleq 'portion.' Qohelet emphasizes that people must enjoy their portion while it is still possible, for in Sheol all that seems important to mortals will not matter anymore: not reward, not reputation, not passion, not accomplishments, not reason, not knowledge, not wisdom $(9: 5-10) .{ }^{62}$ Qohelet $9: 1-12$ is especially telling of the relationship between the inevitability of death $(9: 2-6,10)$, time and chance (9:11-12), and the enjoyment of life (9:10). The three motifs converge in the injunction of verse 10: "Whatever your hand finds to do, do it with all your might, for in the grave, where you are going, there is neither working nor planning nor knowledge nor

${ }^{61}$ As will be demonstrated in the following chapter, there are many scholars who do not view the enjoyment of life as co-equal in comparison to other more somber motifs. Burkes writes, "Some have taken the counsel to make merry as the main theme of the book, and therefore read the text largely as a "divine imperative of joy.' However, the context as a whole suggests that these notes of joy are a meager tune in a work that plays in a somber key (Burkes, Death in Qoheleth, 73-74)." As will be argued in the following chapter, I would have to side with the "some" of whom Burkes refers, although I do so without minimizing the significance of the death motif in Qohelet's greater line of argument.

${ }^{62}$ Seow, Ecclesiastes, 58. 
wisdom." ${ }^{63}$ Man does not know the time of his death (it could be short coming), but one thing is certain-it is coming! Therefore, what will the wise man do in the present time that God has given him as a gift? He will certainly enjoy life with a joyful heart all the fleeting (הבל) days of his life, but he will not simply live in the squalor of the sluggard. He will seize the day, understanding that life is a gift that is not guaranteed for tomorrow. Rightly applied, this wisdom is a tremendous word of motivation and godly encouragement, all the while preceded by an acknowledgment of the inevitability and unpredictability of death. However, once again Qohelet cautions the reader with balance and propriety. As much as he enjoys the light of life, the wise man is to remember the days of darkness, for they will be many $(11: 7-8)$. A wise life is a life lived to the fullest, motivated (at least in part) by the anticipation of the grave. A wise life too is lived in sobriety, motivated (implicitly) by the anticipation of judgment beyond the grave. This brings us to the last principle in our survey, the fear of God in the light of mortality.

\section{Principle Five: An Acknowledgment of the Inevitability of Death Will Lead the}

Wise to Remember God $(3: 17 ; 8: 12 ; 11: 9 b ; 12: 1-7,13-14)$. Although critical scholarship is quick to attribute the "fear God" references $(3: 17 ; 8: 12,11: 9 \mathrm{~b}$, and especially $12: 14)$ to a pious redactor, this critical motif is all too well integrated into the theological and ethical claims of the book as a whole to be excised in an ad hoc fashion. ${ }^{64}$ The close relationship between the fear of God and the enjoyment of life, along with each motif's

\footnotetext{
${ }^{63}$ NIV.

${ }^{64}$ Lee, Vitality, 84. See also Antoon Schoors, who states in reference to Qoh 3:17 and 11:9b, "...both these verses are considered a gloss by a considerable number of scholars (Schoors, 'A Perspective of Life after Death?' 299)." For an excellent treatment of Qohelet written from a critical perspective, see John Barton, Reading the Old Testament. While Barton's work is not a commentary on Qohelet, he nevertheless uses Qohelet throughout as an example of critical methodologies applied, and thus Barton's work is representative of the kind of critical methodology applied to Qohelet in the critical commentaries such as Kruger's contribution to the Hermeneia series.
} 
integrative reliance upon the "inevitability of death" motif, argues for a unified line of argument and a unified authorship which incorporates the fear of God as central to wisdom, even the skeptical wisdom of Qohelet. ${ }^{65}$ As Lee states, "The close association between fear and joy in Qohelet's rhetoric suggests that enjoyment is a vital aspect of Qohelet's vision of piety. ${ }^{96} \mathrm{I}$ too would add that this association implies the reverse, and that piety is a central motif based upon its close proximity to enjoyment, and ultimately, to the recognition of the inevitability of death in Qohelet's rhetoric.

In approximating an overview of Qohelet's theology of death, Bailey writes, "And thus does the author overcome nihilism by keeping death within the domain of God's wisdom. Human creatureliness is manifest both in the limitations and in acceptance of the deity's design "that men should fear before him (3:14).."67 The fear of God is thus rightly attributed to an anticipation of God's sovereign and unpredictable determination in the affairs of man "under the sun," but do the "fear of God" injunctions also imply a postmortem existence? Could it be that Qohelet also anticipates an afterlife during which judgment will take place? And ultimately, does the "inevitability of death" motif function as a prime motivator for the wise man to "fear God"?

Kathleen Farmer answers the question regarding the anticipation of an afterlife in the affirmative, but concurs that "Qohelet shares the reticence of most other OT witnesses on the subject of what such an afterlife might look like. ${ }^{968}$ Even though Qohelet implies

\footnotetext{
${ }^{65}$ As I use the term skeptical, this is meant to be understood as reflecting realism, and might better be referenced as "realistic" wisdom.

${ }^{66}$ Lee, Vitality, 85.

${ }^{67}$ Bailey, Biblical Perspectives, 55-57.

${ }^{68}$ Farmer, Who Knows What Is Good?, 206.
} 
that human beings cannot know for sure "what will come after" our brief life "under the sun" $(3: 21 ; 6: 12 ; 7: 14)$, he nevertheless affirms some level of confidence that equity and justice just may have its day in the afterlife, at a postmortem judgment, however vague that judgment may be $(3: 17) .{ }^{69}$ Such a conclusion is implied by the contextual proximity of the "remember God" injunction of $3: 17$ and the (perhaps rhetorical) question of $3: 21$, "Who knows if the spirit of man rises upward and if the spirit of the animal goes down to earth?" In Farmer's view, the confidence in 3:17 that states that there will be an "appropriate time" for judgment "not limited to our lives "under the sun"" is measured against the agnosticism of 3:21, where Qohelet does not know what will come after our lives "under the sun" are over. ${ }^{70}$ However, even a measured affirmation of confidence in a postmortem judgment constitutes an advancement in the Old Testament revelation of the afterlife. ${ }^{71}$

One certainly cannot consider Qoh 3:21 without also considering 12:7, "and the dust returns to the ground it came from, and the spirit returns to God who gave it," a statement many see to be the answer to the question imposed in $3: 21 .^{72}$ At the very least,

${ }^{69}$ Ibid, 205-06.

${ }^{70}$ Ibid, $162-63$.

${ }^{71}$ Of course, as has already been suggested, this view is without great consensus. For instance, Schoors states the exact opposite when he concludes: "It certainly is unwarranted to infer from certain utterances on divine judgment or on the spirit which returns to God that Koheleth would depart from the traditional view. To him, the disappointments with life on this earth are not compensated by the hope of a happy afterlife. On the contrary, his picture of death is rather more negative than that of the Old Testament tradition: he raises the question whether in death, there is any difference between man and beast. One has the impression that in his view, death is even more final than it is in other texts in the Old Testament." See Schoors, “A Perspective of Life after Death?” 303.

${ }^{72}$ Many take a more negative view of the interrogative than I do, viewing it as a rhetorical question reinforcing Qohelet's skepticism "about the possibility of some meaningful afterlife (Frydrych, Living under the Sun, 149)." Schoors, "along with the vast majority of commentators," follows the ancient translators (against the masoretic vocalization), and thus reads the verse as an interrogative (with an interrogative particle) rather than as a statement of fact. Additionally, Schoors holds to the opinion that Qohelet's rhetorical question is a reaction against a common theology that he seeks to refute: "The question 
12:7 is significant in that it implies (together with 3:21) a kind of a body-soul dichotomy that is quite foreign to mainstream Old Testament anthropology. ${ }^{73}$ John Cooper writes in reference to Qoh 12:7, "That verse seemed quite clearly to express a body-soul dichotomy. Although the body decomposes into physical matter, the individual substantial soul survives and ascends to dwell with God." ${ }^{, 74}$ It too is significant that 12:7 is placed not only at the conclusion of the "aging metaphor" of $12: 1-7$, but that this metaphor is introduced contextually by the injunction to "Remember your Creator in the days of your youth (12:1a)." Davis concurs with this observation, stating that "the reference to God provides an effective inclusio to the discussion of death, picturing God both as the One from whom life comes (v. 1) and as the One to whom life returns (v. 7) ${ }^{75}$

in verse 21 seems to be a reply to an objection against the verses 19-20. Koheleth seems to be aware of an opinion, according to which the spirit of man goes upward, to God, whereas that of the beast goes down into the netherworld." See Schoors, "A Perspective of Life after Death?" 301 . However, even if one reads 3:21 as an interrogative, this does not negate the option that Qohelet will later extend his inquiry to embrace a possible, even if clouded, view of post-mortem judgment. Keeping in mind the "under the sun" perspective and the purposefully dialectical nature of Qohelet's inquiry, such a use of the interrogative at this juncture is not to be unexpected.

\footnotetext{
${ }^{73}$ Not all would concur with such an assessment. For instance, Schoors, commenting on Qoh 12:7, writes, "Dying consists precisely in the fact that God takes back the human spirit to Himself and, from this point of view, man and animal are equal." Frydrych too takes an approach that does not force a human dichotomy: "In the context of the whole book, the spirit returning to God is not a quintessential human being freed of the earthly body moving onto a higher level of existence in a spiritual realm. Rather, the spirit is the raw life force that God gave to all living creatures, and which completed its 'service'. By returning the dust back to the earth where it used to be, death restores the initial status quo and closes the profitless circle of existence." See Schoors, "A Perspective of Life after Death?" 302 and Frydrych, Living under the Sun, 149.

${ }^{74}$ John W. Cooper, Body, Soul, and Life Everlasting (Grand Rapids: Eerdmans, 1989): 34. Cooper's view should not be overstated; as referenced above, the body-soul dichotomy in 12:7 is merely implied, not stated as fact. One could just as easily argue that the nin of man refers to the breath of life, where parallels life rather than contrasts with the material body (Isa 42:5).

${ }^{75}$ Davis, "Death, an Impetus for Life," 352. Although Davis states that "Death, simply and finally, is the separation of body and spirit," he too is quick to buttress that statement with a word of caution: "An important point to note, however, is that the purpose in verse 7 (and throughout the book of Ecclesiastes) is not to present a theology of the afterlife. The goal was not to have readers understand the details of life after death, but rather to have them recognize the fact of the existence of an afterlife so that they might live eternally purposeful lives here and now." (364)
} 
The final two verses of Qohelet (12:13-14) also function to admonish the fear of God, not in particular reference to any one of the "inevitability of death" judgments, or even to any one of the "הבל" judgments, but as a means to conclude a book which is wholly inundated with the pervasiveness of the "death" motif. Although these verses are questioned even among conservatives in regard to authorship, they nevertheless stand as integral to the inspired canonical text. ${ }^{76}$ The importance of this text, implied by its "privileged position at the very culmination of the book," should not be underestimated, whoever the words may be attributed to. ${ }^{77}$

The question of interest to the present writer is not whether or not the postscript or epilogue evidences integrity of authorship, but whether or not the postscript functions as a legitimate extension of Qohelet's teachings, especially in light of his reflections on the inevitability of death. According to Lee, the "postscript deliberately makes literary and theological connections with the body of the book that indicate that they ought to be read closely together," so much so that unanimity of authorship is evidenced through literary and thematic continuity. ${ }^{78}$ Furthermore, and of vital importance to the present discussion, the all inclusive injunction to "fear God" applies to all human beings; just as death is no respecter of persons, so the fear of God is the consummate wisdom principle that should be applied to all humankind.

\footnotetext{
${ }^{76}$ Conservatives such as Longman and Provan view 12:9-14 as the work of an epilogist (Longman) or an author (Provan), who while not Qohelet, nevertheless contributes to the inspired text words that are integral to the message of the book as a whole. More critical scholars conclude that the work of the epilogist is actually the pious editing work of a redactor, and thus functions to "correct" the overly irreverent words of cynical sage Qohelet. eight.

${ }^{77}$ Lee, Vitality, 110. The final two verses of Qohelet will be dealt with in greater detail in chapter

${ }^{78}$ Ibid, 113-14. Lee sees the "most obvious connection" in 4:17-5:6. She states, "The syntax of the command in $12: 13 \mathrm{~b}$ is identical to that in $5: 6 \mathrm{~b}$, with the object proposed emphatically." Although commandments are not explicitly referenced in $4: 17-5: 6$ and $8: 5$, the implicit connections are enough to conclude that Qohelet's vision of piety can encompass obedience to the commandments.
} 
Perhaps the most telling evidence connecting the judgment of God in 12:13-14 to a post-mortem reality is the claim that "every hidden thing" will be revealed (12:14b). Although critical scholarship will contend that such a view is evidence of a redactor's Hellenistic worldview, the close syntactical ties to $11: 9$ and the context of death in 12:1-7 imply that this text is in accordance with (or original to) the sage/author Qohelet. ${ }^{79}$ Not only do texts such as $12: 14 \mathrm{~b}$ and $12: 7 \mathrm{~b}$ imply the strong possibility of an afterlife, they also tie the fear of God into the pervasive motif of death. While the wisdom of ancient Israel called for the fear of God as a universal wisdom principle governing the divine/human relationship, and while the covenants of ancient Israel demanded the fear of God as impetus for following his law (Deut 6:13), it is in Qohelet that the Old Testament advances a theology embracing the anticipation of death and postmortem judgment as prime motivation for all humanity to "fear God" in the short span of a "הבל" life. Furthermore, the wise man will "remember God" (12:1) even in the days of youth, for "no man knows when his hour will come" $(9: 12 a)$. While the themes of time and chance, uncertainty regarding the future, and the "Otherness" of God are certainly supported by Qohelet as reasons to fear God (3:11-14), it too should be recognized that in Qohelet's theology death looms as a significant entreaty towards the fear of God. The wise man will recognize the wisdom in such sober thinking.

It has been demonstrated throughout this chapter that for Qohelet the "inevitability of death" functions as a motif of primary significance, both in relationship to the development of Qohelet's theology and in relationship to the inter-dependency of many other prominent motifs. Qohelet recognizes that the spectre of death is as all pervasive as his observation that all is הבל, a concept that at least in part points to the

${ }^{79}$ Ibid, 116. 
transience of all things created, including mankind. As Qohelet observes life from an "under the sun" perspective, he sees that death is the great equalizer, an observation that causes Qohelet no small degree of angst. However, the inequity of death and judgment in this life are not the only things causing Qohelet angst-he also finds great frustration in the inability of wisdom to do anything to predict or control the timing of one's death. Such control is fully in the hands of an incomprehensible God, a God that cannot be fathomed even by the greatest efforts of wisdom (8:16-17). Although wisdom falls short in fathoming the mysteries of God, including his control over man's mortality, Qohelet concludes that wisdom can discern something of the relationship between mortality and divinity-the spectre of death remains over man so that he might know who is divine and who is mortal, and revere the God who is over him (3:14). And for man, this recognition holds great promise when applied through wise living.

For the wise man who considers his own mortality, the inevitable conclusion is a two-fold wisdom response to the inevitability of death. ${ }^{80}$ The wise man will enjoy life as a gift from God all the fleeting days that God has given him; this is his "portion" (הלק) in life, and it should be received as a gift. To add to this thought, the wise man also will make the most of every opportunity, for in the grave, where he is going, "there is neither working nor planning nor knowledge nor wisdom (9:10)." However, wisdom also dictates the fear of God, not due only to the "Otherness" of the divine, but due also to the inevitable judgment of death and the implied account that man will give to God from beyond the grave. Together, these motifs combine to form an advancement in the overall

\footnotetext{
${ }^{80}$ Using the word "response" may not be properly nuanced in regards to Qohelet's journey. In light of Qohelet's quest to find a solution to the "dilemma of הבל," it may be better to recognize this as a wisdom "concession," although I would use that word in as positive a sense as is possible.
} 
theology of death and the afterlife in the Old Testament and a greater understanding of the essential ingredients in Qohelet's wisdom message. ${ }^{81}$

${ }^{81}$ It is important to remember the canonical context of Qohelet as an Old Testament wisdom text. Although an advancement towards a fuller theology of death and the afterlife, Qohelet does not reveal or even imply a joyous heavenly existence for the follower of Yahweh. However, if one keeps in mind the canonical context and the "under the sun" perspective from which Qohelet was written, this should not cause the Christian any concern. Because of the under the sun perspective, Qohelet does not contradict New Testament teaching on the afterlife. Rather, Qohelet functions as a canonical compliment to New Testament teaching. Lohfink correctly mirrors this assessment: "The last books of the Old Testament, and the New Testament, fully legitimate Christian speaking about the other world. However, this should not be used simply to declare Qoheleth wrong. Death does remain the total end of a human being insofar as he or she lives in the time that accompanies living. Christian hope regarding the afterlife must be such that it does not cover over the terminal character of death and the continued dependence of all human things on this life." See Norbert Lohfink, Qoheleth: A Continental Commentary, trans. Sean McEvenue (Minneapolis: Fortress Press, 2003), 16. 


\section{CHAPTER 7}

\section{WHAT WILL THE WISE MAN DO? THE ENJOYMENT OF LIFE CONCLUSIONS IN THE BOOK OF QOHELET}

Standing at the crux of the debate regarding the proper approach to Qohelet is the recurring commendation of joy, the "enjoy life" motif. Qohelet explicitly commends the enjoyment of life seven times $(2: 24 ; 3: 12-13 ; 3: 22 ; 5: 18 ; 8: 15 ; 9: 7-10 ; 11: 8-10)$, ${ }^{1}$ set within the text in such a manner that "virtually every literary unit" is to some degree touched by this repeated refrain. ${ }^{2}$ The even dispersion of the refrain saturates the argument of the book in such a thorough manner that it is difficult to ignore its significance as a motif-indeed, if one were to suppress the significance of the "enjoy life" motif one could just as easily find reason to relegate the הבל motif to obscurity-an approach that is hardly tenable in the world of Qohelet studies. Brown reflects this assessment of the equal prominence between the motif and the "enjoy life" motif by stating, "Given their commonality in language and repetition throughout the book,

\footnotetext{
${ }^{1}$ Most scholars recognize these seven refrains as the total number of "enjoy life" commendations, at least in the technical sense of refrain. However, Lee presses the case that 7:14 should be included among these seven, stating that in 7:14 "the author employs not only the explicit vocabulary of simhah but also various other metaphors and idioms to communicate his commendation of enjoyment. The expression 'be in good' in 7:14 functions precisely in this manner; it therefore appropriately qualifies as a 'joy passage." Nevertheless, Lee's case on lexical, syntactical, and literary grounds is weak; 7:14 expresses a different genre (proverb) than the others, has very little in common with thematic and lexical repetition, and expresses a different syntactical construction than what is repeated in the refrains. See Lee, Vitality, 3.

${ }^{2}$ Lee writes, "Joy appears in virtually every literary unit of the book-with other sobering elements, to be sure, but nonetheless present everywhere." Her observation regarding the pervasiveness of this motif is accurate-indeed, the very interdependency between motifs that stands at the heart of this dissertation suggests that the enjoyment of life motif is influential in understanding the whole of the book. See Lee, Vitality, 3.
} 
Qoheleth's seven commendations constitute the book's refrain as much as his הבל indictment against the created order serves as its motto and rhetorical frame."3

Thematically, the enjoyment of life is as rooted in creation as the הבל indictment is rooted in the fall; ${ }^{4}$ just as the two find their basis in the creation account of Genesis 1-3, so they are intertwined in Qohelet's theological assessment of the cosmos as reflected through his wisdom. ${ }^{5}$ And thus, while it is true that Qohelet's many commendations are embedded within reflections on life's absurdity, ${ }^{6}$ the motif does not overshadow the enjoyment of life. As much as an accurate understanding of the הבל motif is required of any Qohelet exegete, so too must one understand the nature and role of the "enjoy life" motif to reach a balanced approach to Qohelet. Brown's assessment of the exegetical situation is right

\footnotetext{
${ }^{3}$ William P. Brown, "Whatever Your Hand Finds to Do: Qohelet's Work Ethic," Interpretation 55 (2001): 279 .

${ }^{4}$ Admittedly, while this connection is more explicit in reference to the fall and the motif, it is nevertheless inferred in regard to the enjoyment of life. For instance, one finds that the "good" creation of God in the garden was "pleasing" to the eye (Gen 2:9), and the creation of women is said to have stemmed from the fact that it was "not good" for man to be alone (Gen 2:18). Furthermore, the very things commended as good by Qohelet, enjoying life with one's wife, eating, drinking, and finding satisfaction in the work of one's hands, these were all created as "good" prior to the fall. In reference to the connection between the enjoy life refrains and the creation account, Clemens writes, "Thus, it is not possible to return to Eden (cf. 2:4-11). However, it is possible to return to the commands given in Eden, and this is the intent of 2:24-26 and its parallels: God has already approved our eating and work (9:7), because they were prescribed in Eden ..." See David M. Clemens, "The Law of Sin and Death: Ecclesiastes and Genesis 13," Themelios 19 (1994): 5-8.
}

\footnotetext{
${ }^{5}$ Noteworthy is the observation of Robert K. Johnston, who writes, "Ecclesiastes and Genesis exhibit substantial agreement as to the central point of the creation motif - that life is to be celebrated as a 'good' creation of God. Seven times in the opening chapter of Genesis, God looks at his creation and calls it 'good' $(t o b)$. Similarly, Qoheleth views life and concludes: 'There is nothing better [lit., tob, 'good'] for a man, than that he should eat and drink, and that he should make his soul enjoy good (tob) in his labor. This also, I saw was from the hand of God' (2:24)." See Johnston, "Confessions of a Workaholic," $C B Q 38$ (1976): 23.

${ }^{6}$ Brown lists examples of "enjoy life" commendation embedded within examples of absurdity: "the arduousness of toil (2:23), the impenetrability of time (3:11), the fragility of life and ignorance about the future (3:21), the tragic loss of gain (5:13-17), and the overturning of moral standards (8:14)." Indeed, the "enjoy life" refrains are never far removed from the הב indictments so prolific within the text. See Brown, "Qohelet's Work Ethic," 280.
} 
on target: "The significance of Qohelet's commendations with the book as a whole is the interpretive crux of Ecclesiastes."

As is the case with so many of the prominent motifs in Qohelet, there is little consensus regarding the lexical, literary, and theological interpretation of the "enjoy life" refrains. Scholarship can be roughly divided between an optimistic approach and a pessimistic approach to the book; how the "enjoy life" motif is viewed is largely determined by one's approach to the book just as it is influential in determining one's overall approach to the book. Among those who take a positive approach to the "enjoy life" refrains, viewing the commendations as life affirming conclusions to Qohelet's reflections and observations, are recognized scholars such as Graham Ogden, Robert Gordis, R. N. Whybray, Norbert Lohfink and Eunny Lee. Perhaps more numerous are the scholars who take a negative approach to the refrains, included respected names such as James Crenshaw, Tremper Longman III, Roland Murphy, Michael Fox, Thomas Kruger, Frank Zimmerman and W. H. U. Anderson. Of course, as with the variety of approaches to the הבל motif, or to the book itself, it is not as simple as dividing the lot between positive and negative approaches. There are a variety of nuanced approaches to the issue. For instance, among those who take a predominantly negative approach to the nature and the role of the motif, one finds the extreme pessimism of W. H. U. Anderson who refers to the "enjoy life" refrains as being simply "wishful thinking," relegating the role of these refrains to that of literary "tropes"-figurative devices whereby the "enjoy life" statements are limited by the contrastive value of their surrounding contexts. ${ }^{8}$ Kruger views the

\footnotetext{
${ }^{7}$ Ibid, 279.

${ }^{8}$ Anderson does not define nor explain how he uses the term "trope" in reference to the "enjoy life" statements. The above definition comes as a result of speculation based upon Anderson's use of the
} 
"enjoy life" motif as a commendation to hedonism, viewing the commendations of joy as one and the same with the experiences of pleasure described in $2: 1-10 .{ }^{9}$ Longman views the refrain not as a commendation or a conclusion, but rather, as a concession; a numbing "narcotic" that eases the pain of life lived in a "meaningless" existence. ${ }^{10}$ Furthermore, in Longman's view, the concession of which Qohelet recommends is hardly autobiographical. Of Qohelet's inability to experience joy, Longman writes, "Indeed, it is clear throughout the book that though God grants enjoyment to some, Qohelet does not identify himself among the privileged few (6:2)."11 Crenshaw, like Longman, takes a rather pessimistic view towards the "enjoy life" refrains, stating that one may "enjoy life if you can," but "even as you enjoy, know that life is meaningless." 12 In line with Longman, Murphy also views the enjoyment of life as a concession: "Qoheleth is not expressing a verdict about values in life, and expressions like these are not a positive recommendation. They are a concession to human nature."13 In evaluating the approaches of various authors, Eunny Lee observes that Fox "likens the persistent endorsement of enjoyment to the 'gesticulations of a lunatic,' a senseless activity that is meaningful only in a crazed person's private world." 14 Perhaps the most shocking of the

term in its various contexts throughout his book. See W. H. U. Anderson, Pessimistic Theology, 71-73, 106-07.

${ }^{9}$ Kruger, Qoheleth, 3.

${ }^{10}$ Longman, Ecclesiastes, 35.

${ }^{11}$ Ibid, 106.

${ }^{12}$ Crenshaw, Ecclesiastes, 23. Crenshaw further describes the enjoyment of which Qohelet speaks as "little pleasures to sooth the troubled spirit (Crenshaw, Ecclesiastes, 27)."

${ }^{13}$ Murphy, Ecclesiastes, 1x.

${ }^{14}$ Lee, Vitality, 4. See also Fox, A Time to Tear Down, 130. 
negative assessments is that of Frank Zimmerman who suggests "that the counsels of joy are a reflex of the author's conflicted psychological make-up that arose as a result of his troubled childhood and marital experiences." 15

Bridging the gap between the negative and positive schools of thought is ChoonLeong Seow, who views enjoyment as the "antidote to people's experience of all that is bad," 16 yet balances his approach by viewing enjoyment not as "a hedonistic ideal, but rather, as "a responsibility" before God. ${ }^{17}$ Stephen de Jong takes an anthropological, and perhaps, more neutral approach to the "enjoy life" motif, stating that "[I]n contrast to the interpretation of many authors, it should be stated that these enjoyment texts do not contain an appeal to a joyful acceptance, a carpe diem stance toward life . . enjoying life is not in the power of human beings . . the enjoyment texts underline the impotence of the individual." 18 Thus, in de Jong's view, the enjoyment texts are nothing more than a theological foil set in the text to accentuate and highlight the impotence of man, which is the real theological thrust of the text.

In contrast to those who relegate the enjoyment texts to obscurity, or who otherwise shift the focus of these texts away from the affirmative, stand a minority of scholars who elevate the "enjoy life" motif to prominence and affirm its teachings as a positive, wisdom based counsel for godly living. Robert Gordis views the theme of enjoyment as the basic message of the book, elevating the theme to a preeminent role in

\footnotetext{
${ }^{15}$ See Frank Zimmerman, The Inner World of Qohelet (New York: KTAV, 1973), quoted as assessed by Eunny Lee, The Vitality of Enjoyment, 4.

${ }^{16}$ Seow, Ecclesiastes, 157. 244.

${ }^{17}$ Choon-Leong Seow, "Theology When Everything is out of Control," Interpretation 55 (2001):

${ }^{18}$ Stephen de Jong, "A Book on Labour: The Structuring Principles and the Main Theme of the Book of Qohelet," JSOT 54 (1992): 111.
} 
Qohelet's rhetoric. ${ }^{19}$ Ogden likewise views the refrains as "theological statements of faith," thereby taking an affirmative view of the role of enjoyment in Qohelet's message. ${ }^{20}$ Lohfink views the enjoyment of life as God's response to man's dilemma of death's enigma; as I would view it, the dilemma of living in a הבל world..$^{21}$ Agustinus Gianto echoes these thoughts by arguing that "enjoyment . . . gradually emerges as an alternative to the reality of hebel., ${ }^{92}$

Perhaps the best known proponent of the prominence of joy in Qohelet is R. N. Whybray by way of his 1982 article "Qoheleth, Preacher of Joy.",23 In this oft referenced article, Whybray proposes that the seven "enjoy life" refrains "are clearly more than mere marginal comments or asides." 24 He continues by stating that "[T]hey punctuate the whole book, forming a kind of Lietmotiv; they increase steadily in emphasis as the book proceeds; and the last, the most elaborate of them all, directly addressed to the reader, introduces and dominates the concluding section of the book in which Qoheleth presents his final thoughts on how life should be lived and why." 25 Perhaps most significant is Whybray's emphasis upon the imperative nature of these texts. He rightly observes the escalating nature of the imperative-beginning with the assertion of understanding $(2: 24$;

${ }^{19}$ Gordis, Kohelet, 131.

${ }^{20}$ Ogden, Qoheleth, 22.

${ }^{21}$ Norbert Lohfink, "Qoheleth 5:17-19-Revelation by joy," $C B Q 52$ (1990): 625-35.

${ }^{22}$ A. Gianto, “The Theme of Enjoyment in Qohelet," Bib 73 (1992): 530.

${ }^{23}$ It is only fair to remember that Whybray is dubbed a proponent of such a view based primarily on his 1982 article. Garrett observes in his 1993 NAC commentary that "Whybray himself appears to shy away from calling the teacher a 'preacher of joy' in his later (1989) commentary on Ecclesiastes. He instead speaks of him as a realist and also gives a good deal of attention to the Teacher's theological emphasis (Whybray, Ecclesiastes, 211-28)." See Garrett, Proverbs/Ecclesiastes/Song of Songs , 273.

${ }^{24}$ Whybray, Preacher of Joy, 88.

25 Ibid. 
$3: 12 ; 3: 22 ; 5: 17),{ }^{26}$ proceeding to the level of affirmation $(8: 15)$, and concluding with two imperative wisdom injunctions to live joyfully $(9: 7-9 ; 11: 8-10) .{ }^{27}$

The most extensive treatment to date in support of a positive approach to the "enjoy life" motif is that of Eunny Lee, The Vitality of Enjoyment in Qohelet's

Theological Rhetoric. Based upon her dissertation submitted to the biblical studies department of Princeton Theological Seminary, Lee proposes that the enjoyment of life is presented in Qohelet as an ethical and theological commandment, a wisdom mandate wherein the enjoyment of life is not only a wise approach to life-it is also a righteous approach to life. Thus she is able to capably defend a positive approach to the enjoyment of life, approaching it as a God honoring, wisdom based carpe diem, neither indifferent to the sober recognition of life's "hevelness" nor diminishing the fear of God as the root of all wisdom. Rather, she proposes that life ought to be enjoyed in light of the reality of these things; indeed, an accurate assessment of the "enjoy life" motif ought not to be described as pessimistic or optimistic, positive or negative, but rather, as realistic. ${ }^{28}$ Rather than describing her own approach as positive, Lee describes her understanding of Qohelet's view towards enjoyment as "faithful realism," the notion that "enjoyment, for Qohelet, has to do with living life to the full, with a sober recognition of its travails and a grateful acceptance of its possibilities. ${ }^{29}$ Following the approach of Lee, I too see the

\footnotetext{
${ }^{26}$ Whybray places an emphasis in his evaluation of these texts upon the asseverative nature of their introductions. While I would agree that the tone of these texts is tempered, I think that it may be a bit much to describe them as solemn. Thus, based initially on Whybray, but taking some liberty of departure, I am simply observing that Qohelet has come to a point of understanding as revealed by his "plain statement" in 2:24 and his introductory phraseology in 3:12,3:22, and 5:17. See Whybray, Preacher of Joy, 87.

${ }^{27}$ Ibid, 87-88.

${ }^{28}$ Lee, Vitality, 8.

${ }^{29}$ Ibid, $8,9$.
} 
enjoyment of life as Qohelet's wisdom mantra, one side of a two sided wisdom conclusion that provides inspired insight into living life to its fullest potential. ${ }^{30}$

Germaine to the study of the "enjoy life" motif is the semantic flexibility of Qohelet's usage of words and expressions related to and derived from the root שמחה. Those who take a more negative view towards the "enjoy life" refrains, seeing them as mere concessions, will tend to gravitate towards a uniform approach, viewing Qohelet's experiment with pleasure (שנהח) in Qoh 2:1-9 with the same connotation as the call to enjoyment (שנה) found in each of the seven refrains. For instance, regarding the issue of semantic distinction between pleasure and joy, Fox writes, "Simhah in Qohelet means pleasure, not happiness and certainly not joy." 32 Reinforcing this thought, Fox asserts that "simhah never means happiness in Qohelet. Indeed, the pleasures called simhah never even seem to produce happiness in him. ${ }^{, 33}$ Furthermore, he contends that "Qohelet is a 'preacher of pleasure ${ }^{, 34}-$ not because he is a hedonist who relishes sensual delights, but because, faute de mieux, pleasure remains tob, 'good,' whatever its inadequacies." 35

On the other hand, even while viewing the literary tie between $2: 1$ and $8: 15$ through the lens of inclusio (2:1, 'I said that'; 8:14, 'I said that'), Gianto distinguishes

${ }^{30}$ The other side of this "two-sided wisdom coin" is the fear of God, a subject also taken up by Lee. I too will treat the fear of God as an essential "inter-dependant" motif in the following chapter. See especially Lee, Vitality, 83-122.

${ }^{31}$ Gianto, "The Theme of Enjoyment," 528.

${ }^{32}$ Fox, A Time to Tear Down, 113.

33 Ibid, 115. Joy."

${ }^{34}$ It is assumed that Fox is using a play on words here-a direct allusion to Whybray's "Preacher of

${ }^{35}$ Fox takes this argument a step further by distancing himself from attributing moral ramifications upon "good" and "joy" as they are used in Qohelet, with the exception of 7:20 and 9:2, neither of which constitute a portion of an "enjoy life" refrain. See Fox, $A$ Time to Tear Down, 115-16. 
between these texts, recognizing that in 2:1 "simhah refers to pleasure in general," but noting that "Qohelet deepens the meaning of the word in his subsequent reflections." 36 Thus, Gianto concludes that "[I]n 5:9 the word refers to the inner joy inspired by God" and that "[I]t is precisely this simhah that Qohelet praises in $8: 15 .{ }^{, 37}$ Furthermore, in reference to $9: 7$ and 11:9, Gianto asserts that "rejoicing ... should be interpreted as the inner joy which comes from God,",38 thus clearly seeing a contextually based semantic distinction in Qohelet's line of argument between external pleasures taken up through human striving and inner joy received as God's gift.

The term שמש occurs some 275 times in the Old Testament. The term is commonly employed in reference to Israel's festival celebrations, ${ }^{39}$ exhortations to rejoice in the Psalter, ${ }^{40}$ and in reference to the days of restoration promised by the prophets. ${ }^{41}$ God himself is often the one who rejoices (Ps 104:31; Zeph 3:17), and while in most contexts humans rejoice in view of religious festivity, praise, and hope, the term can be applied to the more "secular" realm as well (the husband is counseled to "rejoice" in the wife of his youth; Prov 5:18). ${ }^{42}$ Thus, while there may be a sense in which שנכ could refer to pleasure in certain contexts (as in the example above; Prov 5:18), the term clearly is used in the vast majority of cases to refer to rejoicing in the context of worship and piety. It

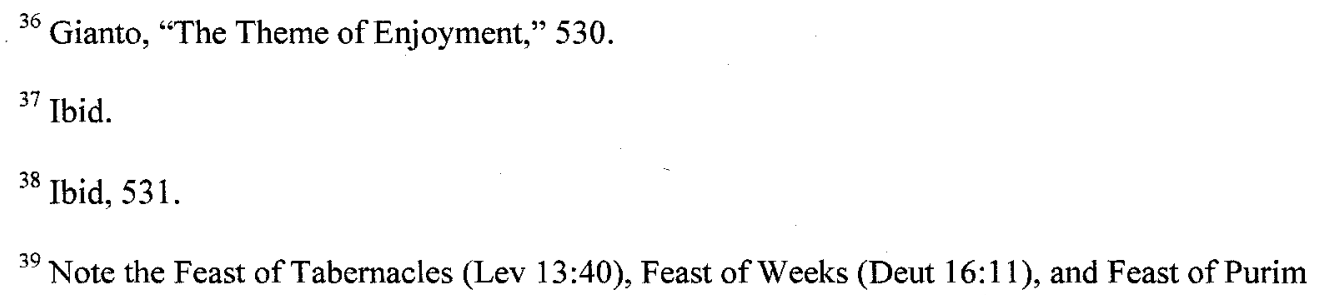
(Esth 8:16-17, 9:17-19, 22).

${ }^{40}$ Roughly one quarter of the occurrences of שin in the OT are in the Psalter. See Michael A. Grisanti, NIDOTTE, 1251.

${ }^{41}$ Isa $51: 3,11 ; 55: 12 ; 61: 7 ;$ Jer 33:11; Zeph $3: 14 ;$ Zech 8:19.

${ }^{42}$ Grisanti, NIDOTTE, 1251-254. 
would therefore be too semantically narrow to view enjoyment in Qohelet as mere hedonism, as would it be inaccurate to over-spiritualize joy as an expression of inner-joy removed from the external experiences that bring physical and emotional pleasure. Qohelet's exhortations to pleasure are pragmatic as they are theological; he commends the enjoyment of life, in full view of life's simple pleasure yet in acknowledgment that joy ultimately comes as a gift from God. His commendations are neither excessive nor irresponsible. Rather, they are a reflection of a balanced, wisdom based approach to life as received from and acknowledged by the hand of God.

Taking note of the persistence, prominence, and even dispersion of the "enjoy life" refrains, how is it that some have found reason to dismiss these commendations as "peripheral digression" ${ }^{43}$ Some have chosen to see a double minded Qohelet in the text ${ }^{44}$ while others have attributed discordance as the work of later redactors,${ }^{45}$ but neither of these approaches are convincing in light of the clear literary strategy (grammatical and rhetorical) through which these passages appear in the text. To view the refrains as mere concession is to undermine the point altogether; on what basis do these scholars justify relegating the clear affirmation of enjoyment $(5: 19 ; 8: 15)$ and the imperative commendations to enjoy life $(9: 7-9 ; 11: 9)$ into the defeatism of concession? True, Qohelet does indeed paint a dire picture of life lived apart from enjoyment, most notably in his reflections on the oppressed (4:1-3) and on those for whom the ability to

\footnotetext{
${ }^{43}$ Lee, recognizing the persistence of this motif, writes, "Qohelet's persistent call to enjoy life simply cannot and must not be written off as a contradictory strain or a peripheral digression. It is vital to his teachings." See Lee, Vitality, 81 .

${ }^{44}$ Note for instance the theories of W. H. U. Anderson ("wishful thinking") and Frank Zimmerman (psychological distortion). See Anderson, Pessimistic Theology and Zimmerman, Inner World of Qohelet.

${ }^{45}$ I am not aware of any scholars who make a point to explain away the "enjoy life" refrains by way of redaction, although this strategy is common in reference to the "fear God" motif.
} 
enjoy possessions are withheld (6:1-6). ${ }^{46}$ But these reflections, made from an "under the sun" perspective, entertain hypothetical cases wherein Qohelet's very premise on the vitality of enjoyment is countered in this הבל world. Perhaps with a bit of hyperbole, Qohelet makes the point-a life lived apart from the experience or ability to experience joy is not a life worth living, at least in the sense of living in full. Qohelet is not necessarily commenting on the sanctity of life. His concern is with the quality of life, and he sets as a foil the most dire and sad of circumstances to heighten his commendation for enjoyment in the present experience of living.

One of the best arguments for taking a positive view toward the "enjoy life" refrains is the clear escalation that takes place via the introduction to each refrain. As previously noted in Whybray, the commendations gain momentum from plain statements of understanding $(2: 24 ; 3: 12 ; 3: 22 ; 5: 17)$ to clear commendation $(8: 15)$ and conclude with imperative injunction $(9: 7 ; 11: 9)$. Years later, Whybray again notes the rhetorical strategy in this escalation: "These seven passages clearly form a series; and, in the book as it is now arranged, it is a series which is marked by a steady increase in emphasis." ${ }^{47}$ Although the first five "enjoy life" refrains could be construed as concession, it is difficult to imagine the final imperatives as concessional, especially in light of the heightened exhurberance in which they are cased and the shift from first person observation to second person imperative.

\footnotetext{
${ }^{46}$ Whybray notes as well the "famous phrase" in 2:17, "So I hated life," although I disagree with his conclusion that this expression "proves on examination to be an expression not of Qoheleth's own teaching but of the thoughts of the supposed Solomon, reflecting the disillusionment which he felt before he came to make the more mature reflections which culminate in the positive conclusion of 2:24-26." I find no reason to support an authorial division between $2: 17$ and 2:24-26, whether they be between two stages in "Solomon's" maturity or a hypothetical division between autobiographical commendations and the reflections of a literary guise. See Whybray, "Preacher of Joy," 92-93.

${ }^{47}$ Whybray, Ecclesiastes, 64.
} 
Escalation, however, is not the only key to thematic continuity and prominence of role; here too one finds in the refrains obvious repetition of vocabulary, much like that found in the הבל indictments. Although a shift occurs between first person verbal introductions ("I know," 3:12-13; "I saw," 3:22; "I have seen," 5:17; "I commend," 8:15) and second person imperatives ("Go," 9:7; "Rejoice," 11:9) as the text progresses, and although the refrains demonstrate flexibility of form between them, there is nevertheless a striking degree of similarity. Four out of the first five refrains are introduced with the phrase "אין טיב ("there is nothing better"), ${ }^{48}$ a comparative phrase recognized as Qohelet's "call to enjoyment," pleasure (2:1-10). Ogden notes that this phrase comes as a response to the discovery of "no יתרין"-basically, with the programmatic question asked in 1:3, and the initial answer given in 2:11, Qohelet then proceeds to answer the secondary question (2:3b) through the form of the טין טוב phrases. ${ }^{50}$ As advice given in light of the discovery that there is no יתרון, the "enjoy life" refrains are highlighted by the שין phases, not in the sense of concession, but as further developed in later imperative refrains, as a divinely endorsed answer to the question "what good is there for men $(2: 3 ; 6: 12) ?$ ?"51

\footnotetext{
${ }^{48}$ Although most English translations are consistent in their translation of the Hebrew phrase, Ingram is correct in demonstrating the syntactical options (and in his view, ambiguity) for the translation of this phrase. In $2: 24 ; 3: 12,13$, and $8: 15$ he elects to translate "There is nothing good in the person who... (2:24)," "there is nothing good in them except . . 3:12,13)," and "there is nothing good for a person under the sun except... (8:15)." Ingram too points out the textual difficulties with $2: 24$. For an excellent overview of the textual and exegetical options for this phrase, including its rare usage outside of Qohelet, see Ingram, Ambiguity, 182-93.

${ }^{49}$ Ingram, Ambiguity, 182.

${ }^{50}$ Graham Ogden, “Qoheleth's Use of the 'Nothing is Better'-Form,” JBL 98 (1979): 345.

${ }^{51}$ On the pivotal role of $2: 3$ and 6:12 in introducing (2:3) and reintroducing (6:12) the "enjoy life" refrains, see Ingram, Ambiguity, 169-71. Ingram cites others who affirm the importance of these questions; although he notes that most commentators pass over them with little or no comment. Among those who recognize the key role that this question plays in the development of Qohelet's thought, Ingram cites
} 
Thematically, other phrases also function to highlight the significance of the "enjoy life" refrain and draw attention to its content. Each refrain makes reference to either "seeing good," "enjoying life," or "rejoicing," using a form of שמכה often reinforced with the injunction to "see good" (ראה עיב). Each refrain (with the exception of 2:24) either references the limited duration of one's life (3:12), is set within the clear context of the inevitability of death (3:22), makes reference to the "few days" of one's life ( $5: 17$; $8: 15)$, or makes reference to the brevity (הבל) of one's life $(9: 9 ; 11: 10)$. With the exception of 11:9-10, each refrain places enjoyment squarely in the realm of work, or עמל "toil," and in three texts, this is described as being performed "under the sun" (5:17; 8:15; 9:7-9). With the exception of 3:22 and 11:9-10, each refrain describes either life or the enjoyment of life as a gift given by God, often elaborated upon in terms of "eating and drinking" (again, with the exception of 3:22 and 11:9-10). Finally, three of the seven refrains describe enjoyment as one's "lot" or "portion" (חלק) in life (3:22; 5:17; 9:7-9).

This quick survey of repeated words and phrases in the seven "enjoy life" refrains highlights central thematic elements within the "enjoy life" motif. One cannot help but notice the tight connection between work (עai) and enjoyment in these refrains, a situation that creates quite the paradox for those who view enjoyment as recreational hedonism. ${ }^{53}$ One also notices that the enjoyment of life comes as a gift from God, and is

Dominic Rudman, Determinism in the Book of Ecclesiastes. JSOTSup 316, (Sheffield: Sheffield Academic Press, 2001), 82 and Leo Purdue, Wisdom and Creation, 226. I too would include in this list Eunny Lee, Vitality, 36; Thomas Kruger, Qoheleth, 1; and Kathleen Farmer, at least as it pertains to the role of 6:12 in Qohelet's rhetoric (Farmer, Who Knows What is Good?).

${ }^{52}$ For an excellent table comparing the Hebrew contents of the first five refrains (and an English translation for all seven), see Ingram, Ambiguity, 184.

${ }^{53}$ Brown recognizes the difficulty in viewing joy as a "narcotic," an "antidote," "psychological relief," or by implication, hedonism, in light of the tight connection between joy and work in Qohelet's refrains. Concerning these, he writes, "The fact that Qoheleth's taxonomy of joy includes not only the 
appointed unto man as his given "lot" (חלק) in life. With the recognition of as a divinely appointed gift, one must also assess the relationship between divine determinacy and the enjoyment of life. Finally, as the theological and practical value of enjoyment in Qohelet's rhetoric is examined, one again comes back to the role of enjoyment as wisdom; balanced by the fear of God, invigorated by the possibilities of the present, somber in reflection of the future, and always cognizant of the inevitability of death. To these issues we now turn.

\section{Uncomfortable Bedfellows: Joy in the Mist of Toil}

It is difficult to disassociate the enjoyment of life and the toil of labor in Qohelet's theology and wisdom. Brown's assessment is true to the text when he states, "The gift of enjoyment and the futility of gain are two sides of the same coin of Qoheleth's message. ${ }^{~}{ }^{54}$ And yet the relationship is not a simple one-just as joy can be received in the present as a gift from God or squandered for future loss in the excesses of hedonism, so too can toil be expended for fleeting gain or enjoyed in present satisfaction. Thus the "two sided coin" represents two opposing forces as much as it does two forces working in tandem-a wise perspective on work and joy will lead to satisfaction, while striving for gain will only lead to inevitable despair in the face of life's hevelness.

Brown comments that "receiving joy and striving for gain represent two diametrically opposed life orientations: one rushes headlong into the ever elusive future, and the other anchors itself in the inescapable present. ${ }^{.55}$ Yet at the same time, this does

delights of basic sustenance ('eating' and 'drinking') but also work and community (e.g., Eccl. 3:22; 9:710) suggests otherwise." See Brown, Ecclesiastes, 127.

${ }^{54}$ Brown, Ecclesiastes, 127. 
not divorce joy from the daily grind; indeed, the joy that Qohelet advocates "takes place in the grueling labor of living." 56 So while it is certainly true that Qohelet is an advocate of joy, it is equally true that Qohelet is an advocate of work. ${ }^{57}$ The key to this relationship however is one of attitude, orientation, and expectation. Johnston is quite correct in his thesis when he states that "enjoyment, not work, is to be our controlling metaphor of life." ${ }^{\circ 8}$ Nevertheless, this only demonstrates that work should not control man, but rather, man must control in and through his own orientation the toil of his present grind.

Essential to understanding the relationship between work and joy in Qohelet is grasping an accurate understanding of Qohelet's use of the key word עמל, most often translated as "work" or "toil." As with other words frequently employed by Qohelet, there is a certain degree of ambiguity in how he uses the term, and commentators are divided as to how best to translate the term in the various contexts in which it is found. ${ }^{59}$ Although the term has a rather wide semantic domain, translating into a variety of potential glosses, Fox observes:

Throughout the Bible, amal carries gloomy connotations. It first of all means toilarduous, wearisome work. This is its etymological meaning, broadly represented

55 Ibid.

${ }^{56}$ Lee, Vitality, 81.

${ }^{57}$ Lee comments on the necessary bond between work and joy: "Enjoyment is not about avoiding or minimizing unpleasant experiences. It takes place in the midst of backbreaking toil, which Qohelet accepts as an inescapable feature of life." The point here is that Qohelet is not simply an advocate of hard work (although his wisdom bears this out, cf. 4:5; 10:18), but he is a practical observer of life, and recognizes that the toil of work cannot be divorced from the curse of living in a הבל world. See Lee, Vitality, 60-61.

${ }^{58}$ Johnston, "Confessions of a Workaholic," 19.

${ }^{59}$ Ingram examines the word עas yet another term supporting his thesis regarding the intentional ambiguity inherent within Qohelet. Of this term, Fox too refers to the "troublesome ambiguity" encumbering the understanding of this term, as does Crenshaw, who in reference to the use of $2: 10$, writes of "Qohelet's fondness for wrenching more than one meaning out of a word ..." See Ingram, Ambiguity, 150-60; Fox, Qohelet, 55; and Crenshaw, Ecclesiastes, 82. 
in cognate languages. It can refer to the wealth that these labors produce. It can also be extended to denote difficulties and evils apart from labor. ${ }^{60}$

Drawing attention to the more particular focus found in Qohelet, Fox writes:

When signifying activity, amal always means onerous, strained labor, "overdoing" rather than simply "doing." This is the usual meaning of amal in Qohelet. Elsewhere in $\mathrm{BH}$, this meaning is infrequent. ${ }^{61}$

Lee follows after Fox's assessment of the word, stating that the word "often has a somber connotation, signifying arduous and wearisome work, or overwork." Lee also affirms the breadth of the semantic applications when she writes, "By extension, the word may also denote difficulties and misery apart from labor. Indeed, in Qohelet's rhetoric, the word broadly signifies the burden of living in a troubled world, and on occasion, appears to be functionally equivalent to life (see 3:12f; 2:17f; 9:9). For Qohelet, toil is what characterizes life." 92

Others, however, tend to view the term, at least as used by Qohelet, in less negative terms. Whybray, while recognizing the negative overtones of the word in biblical Hebrew, favors an application in Qohelet that is more akin to the neutral connotation espoused in post-biblical Hebrew, wherein the term can be simply translated "work." Ogden and Zogbo nuance the meaning by stating that "refers to heavy labor, work that is physically tiring but nevertheless rewarding. ${ }^{.64}$ Ingram is likely

\footnotetext{
${ }^{60}$ Fox, Time to Tear Down, 98.

${ }^{61}$ Ibid.

${ }^{62}$ Lee, Vitality, 60.

${ }^{63}$ Whybray, Ecclesiastes, 37.

${ }^{64}$ Ogden and Zogbo, A Handbook on Ecclesiastes, 24. Ingram, citing Ogden and Zogbo, proceeds to reference commentators who translate the term as "work" or "labor" rather than the more pejorative "toil," citing Farmer (Who Knows What is Good?, 152-53) and Garrett (Proverbs/Ecclesiastes/Song of
} Songs). See Ingram, Ambiguity, 151. 
accurate in stating that for the early readers of Qohelet, the post-biblical emphasis on work, as removed from sorrow and misery, may have been influential in how the term was understood. ${ }^{65}$ However, it is difficult to ignore the term's negative connotations in biblical Hebrew as well as in the contextual flow of Qohelet's thought-thus, as is the case with the term one must assess meaning case by case, keeping in mind the likely multivalent scope envisioned by the original author.

Whether or not Qohelet had in mind toilsome labor, or "overwork," in the "enjoy life" refrains, or simply "demanding but daily labor" is likely inconsequential to the final assessment of the relationship between joy and work in Qohelet's thought. However, the term's multivalency does produce the possibility of an additional connotation that would remove joy from the midst of work altogether. In the "enjoy life" refrains, עaל has the capacity to refer to the product of work/toil rather than to work/toil itself, thus calling upon some to translate the term in these cases as "possessions" or "wealth." it is a different thing altogether to find joy in one's possessions rather than in one's work. The difficulty here is that grammar, syntax, and context do little to clarify the meaning of the term. As Ingram notes in regard to the use of עמל in the "enjoy life" refrains, "In all these instances, whether the context is positive or negative, there is no indication that is itself positive or negative." ${ }^{67} \mathrm{He}$ concludes that it is best to simply "view the word itself as neutral, meaning simply 'work' or 'the results of one's work," noting too that "although the majority of commentators and English versions render the noun 'work" or

${ }^{65}$ Ingram, Ambiguity, 153.

${ }^{66}$ Fox cites Ginsberg who says that "in Qohelet the verb amal 'almost always' means 'acquire' or 'possess' and the noun means 'possessions,' 'wealth'." Fox affirms this, at least in reference to the "enjoy life" refrains, stating that "it is clear that what is actually being praised is toil's product." See Fox, A Time to Tear Down, 100.

${ }^{67}$ Ingram, Ambiguity, 156. 
'toil' in most cases, it would at least be possible in many verses to translate it as "wealth." ",68 Ingram is correct in his view that the term is ambiguous, and that there would be a certain irony in cases where Qohelet would come to "hate" his wealth (עמל) for leaving him without יתרון $(2: 11,18) .^{69}$ The beauty of ambiguity, along with multivalency, is that the reader does not need to struggle with "either/or" options when "both/and" options work just as well. The "enjoy life" refrains certainly argue in support of "enjoyment" (שמכ) being experienced in the midst of one's עמל, however, it should not surprise us if Qohelet is suggesting that שמח be experienced in the midst of one's toilsome work (עמל), in the midst of one's neutral labor (עמל), and through the satisfaction (5:1718) of one's wealth and possessions (עמל), the products of one's labor (עמל by extension). Whatever the sense of עמל, one gets the impression from the "enjoy life" refrains that Qohelet's commendations of enjoyment are rooted not in the excesses of obsessive toil $(2: 22-23 ; 4: 8 ; 8: 16)$, nor in the extravagant wealth experienced in $2: 1-10$, but rather in the "simple, unpretentious, and consistently commonplace" examples given throughout the refrains: eating, drinking, finding satisfaction in one's labor, and the companionship of one's own spouse $(2: 24 ; 3: 12 ; 5: 17 ; 8: 15 ; 9: 7-9) .{ }^{70}$ Assuming the priority of עמל activity rather than עמל as result, one finds Qohelet's theology of work reflective of that found in Genesis 1-3, where work is both a bane and a blessing; created as a blessing but corrupted through the fall to become for man every negative connotation implied through Qohelet's use of עמל. Yמל הבל world God has given man the ability to enjoy some semblance of the "good" originally envisioned within the design of "work." Rooted

\footnotetext{
${ }^{68}$ Ibid.

${ }^{69}$ Ibid, 156-57.

${ }^{70}$ Brown, "Whatever Your Hand Finds to Do," 280.
} 
in creation, God designed work and enjoyment to be consonant companions. ${ }^{71}$ Received as a gift, and recognized through the faculties of wisdom, Qohelet teaches that with God's blessing man may actually redeem the despair of toil into the satisfaction of meaningful labor. The key to this redemption of work is the reception of joy in one's life. Qohelet is first and foremost a realist, and if anything is real in the experience of man, it is the sweat of his labors. However, Qohelet is not so cynical as to not realize the wisdom of enjoying one's work, both the process as well as the fruit, in the few short days of one's life. Enjoyment is not dependent upon material gain; ${ }^{72}$ as a matter of fact, to Qohelet's great vexation, one may labor in this wבל world only to never experience joy (2:21-23; $4: 8 ; 5: 9$ [Hebrew]; 6:1-3). If God has given man the opportunity to enjoy life, only the fool would squander such a blessing in striving after ill-sought gain. To the contrary, Qohelet encourages the wisdom of vigorous work and festive enjoyment in the everyday experience of life (9:7-10). Hard work, simple rewards, and the enjoyment of life are fully compatible in Qohelet's theology of the cosmos. Brown sums it up well: "Qoheleth does not, at the end of the day, despise work. He recasts it insofar as he is able to confront honestly and cope realistically with this world of hebel., ${ }^{, 73}$

\footnotetext{
${ }^{71}$ Lee recognizes the irony in joining the two, yet insists on their "organic bond" rooted in creation. She writes, "Although joy and toil are not easy companions, Qohelet insists on an organic bond between the two (Lee, Vitality, 60)."

${ }^{72}$ Lee comments, "For Qohelet, enjoyment is not to be equated with the pursuit of gain or profit (Lee, Vitality, 61)." Brown takes a slightly different bent to the issue by stating, "Unlike gain, which is gleaned from one's labors, enjoyment is found amid the toiling (Brown, "Whatever Your Hand Finds to Do," 281)." In either case, the point is that the greater joy does not come to the one with more wealth and "gain," nor does gain guarantee joy. Furthermore, the person with less may find great joy and satisfaction in his labor. It is all a matter of having the wisdom to receive the opportunity for enjoyment as God provides.
}

${ }^{73}$ Brown, "Whatever Your Hand Finds to Do," 279. 


\section{The Divine Gift of Enjoyment}

Enjoyment in Qohelet's rhetoric is at once presented as both a divinely appointed gift and a human responsibility, ${ }^{74}$ yet in its basest form, the possibility for joy ultimately resides with God. ${ }^{75}$ In four out of the seven "enjoy life" refrains, שמש is clearly presented as a divine gift $(2: 26 ; 3: 12-13,22 ; 5: 19)$, while in $9: 9$ it is further implied (along with life itself) as a gift given by God. Furthermore, although the refrains escalate to the point of imperative in 9:7-10 and 11:9-10, nowhere is enjoyment ever presented as a calling to be pursued, but rather, it is presented as a gift to be embraced. ${ }^{76}$ However, it is important to remember that God's gifts are often presented in phenomenological terms. For instance, no one would contend with the fact that Proverbs 1-9 presents wisdom and knowledge as something to be sought, yet in an equal sense, these are gifts imparted from God. Thus, it is safe to assume that the enjoyment of life, although presented in Qohelet as a gift to be embraced, is nevertheless practically implemented as an entity to be sought after as much as it is a gift to be received. Qohelet, I believe, may even suggest that the wise man will recognize the double agency involved in the reception of enjoyment. ${ }^{77}$

\footnotetext{
${ }^{74}$ Seow highlights the balance of "double agency" as applied to the phenomenon of enjoyment as gift and responsibility when he writes, "It [enjoyment] is a 'portion' freely granted by God (3:22; 5:18-19), and that grant implies an accountability for its responsible exploitation: "Follow the ways of your heart and what your eyes see, and know that on account of all these, God will bring you into judgment" (11:9)." This of course also brings up the question of whether or not man will be judged for his response to the reception of enjoyment as a gift, or if the judgment of which Qohelet speaks is set in balance to and regulation of the kind of enjoyment of which Qohelet speaks. This topic will be addressed in the following two chapters. See Seow, "Theology When Everything is out of Control," Interpretation 55 (2001): 244

${ }^{75}$ Lee, Vitality, 36-37.

${ }^{76}$ Seow, "Theology When Everything is out of Control," 244.

${ }^{77}$ Lee brings out this implied human agency, even if only to a lesser degree, when she writes: "Indeed, there is double, if unequal, agency: enjoyment is a possibility for mortals only by the sovereign power of the deity, but they can only have it when they make themselves "see." See Lee, Vitality, 37.
} 
The gift of enjoyment is largely embraced only upon the recognition of its vitality, and to this end, Qohelet must command its recognition in the imperative mood (9:7-10; 11:9-10). ${ }^{78}$ But nevertheless, as an entity, the enjoyment of life does not constitute a far off goal difficult to conceive of, much less achieve. Rather, it is the recognition and acceptance of those gifts already given, yet veiled in the daily routine of life; activities such as eating, drinking, and enjoying life with the wife of one's youth. Thus, enjoyment is not about the accumulation of items which bring pleasure, nor is it about the pursuit of activities producing pleasure. On the other hand, it may be too much to suggest that the enjoyment of life constitutes a piety of rejoicing, or that it requires religious piety to the negation of secular happiness. ${ }^{79}$ In reading Qohelet as wisdom literature, it may be helpful to remember the words of Fee and Stuart in their chapter on wisdom literature: "Not everything in life has to be strictly religious to be godly." enjoyment of life is intricately tied to the fear of God, it is most inherently received as divinely assisted contentment; antithetical to living for the pleasures of excess, a divine

${ }^{78}$ Concerning Qoh 7:14 (which I do not accept as a refrain on the same level as 9:7-10 and 11:910), Lee states, "Divine dispensation is foundational for enjoyment, but human participation is essential for its full realization. So, the sage now commands joy." Her observation is insightful here-God's gift is a necessary prerequisite, but cannot be realized (or received) except through a human recognition of its necessity. See Lee, Vitality, 51.

${ }^{79}$ Polk distinguishes between the "hedonistic" enjoyment of 2:1-10 and the enjoyment of the "enjoy life" refrains, preferring to understand שמכה in these contexts as the more pious "rejoicing," based primarily on the proximity between joy and its origin, who is God. Polk further defines ma as "a state of being, a quality of life that belongs to a relationship with God." Although I do not object to the idea of divine favor in the enjoyment of life, it seems a stretch to infuse the concepts of relationship or piety into Qohelet's use of שמת. See Timothy Polk, "The Wisdom of Irony: A Study of Hebel and its Relation to Joy and Fear of God in Ecclesiastes," SBT 6.1 (1976): 11.

${ }^{80}$ Fee and Stuart, How to Read the Bible, 217. Although I disagree with Fee and Stuart's approach to Qohelet (read as wisdom "foil"), I find their insights on wisdom literature in general to be very helpful. 
"recuperation of the norm." ${ }^{, 81}$ It is nothing more than a "grateful acceptance of God's gifts, indeed, a celebration of divine generosity whenever it is displayed." ${ }^{~} 2$

One of the critical exegetical aspects of assessing this "divine generosity" is coming to a proper understanding of Qohelet's use of the key word חלק. The term is found eight times in Qohelet, with four of these occurrences contained within the "enjoy life" refrains $(3: 22 ; 5: 18,19$ [Hebrew $5: 17,18] ; 9: 9){ }^{83}$ As with so many words in Qohelet's vocabulary, the term הלק has a tendency to carry various connotations depending upon context, and even within context, scholars are not in agreement as to how to best translate the word. ${ }^{84}$ The term is set in contrast to יתרון (2:10-11), and as such, most scholars begin by comparing the "advantage" or "gain" of הלק to that of Some have taken חלק to mean temporary gain as opposed to the permanent gain of ${ }^{85}$ while others have taken a locative approach (rather than temporal), understanding חלק to refer to a limited part as opposed to the whole. ${ }^{86}$ Others have viewed the term as highlighting the

\footnotetext{
${ }^{81}$ Lee, Vitality, 128.

${ }^{82}$ Ibid, 127.

${ }^{83}$ The other occurrences are in $2: 10 ; 2: 21 ; 9: 6$; and $11: 2$. Each reference is insightful in
} understanding the way in which is used in Qohelet, although the primary emphasis in this inquiry is upon the use of the word in the "enjoy life" refrains. The case in 11:2 is found in a proverb, and it use is contextually quite different from the others.

${ }^{84}$ Although Ingram does not treat this word with the same degree of thoroughness as others, it would make another worthwhile candidate for an additional chapter (perhaps affixed to the chapter on יתרוץ). He does however give a brief treatment within his chapter on See Ingram, Ambiguity, 137-39.

${ }^{85}$ See for instance Fredericks, Coping with Transience, 52, 74-75; Whybray, Ecclesiastes, 55; Brown, Ecclesiastes, 33; Farmer, Who Knows What is Good?, 157; and as cited by Fox, A Time to Tear Down, 109-10, E. Wolfel, who writes, "The former [yitron] refers to what endures; the later [heleq] remains within (the realm of) the temporal and transitory. It remains moreover in the realm of enjoyment of material pleasures." See Eberhard Wolfel, Luther und die Skepsis, (Munich, 1958), 75.

${ }^{86}$ Such an understanding would best be conveyed by English glosses such as "portion" or "part." Crenshaw points out that the key component to this thought in Qohelet is that of limitation: "Its essential meaning for him is limitation, a part of something rather than the whole thing." See Crenshaw, Ecclesiastes, 82. 
realm of human existence ${ }^{87}$ or as emphasizing the contrast between the realm of the heavens and that of the earth ${ }^{88}$ Fox dismisses each of the above options, concluding that "[A] heleq is a portion in the sense of possession, something one gets, irrespective of whether it is adequate or satisfying or deserved or durable. ${ }^{989}$ However, Fox views the partialness of a "portion" as only incidental; he continues by stating that the "significant quality of a heleq is its belonging to someone rather than its being fractional or partial."${ }^{90}$ Thus, at least as it pertains to the "enjoy life" refrains, man is given an "allotment" by God (a glass half full view), not simply a "portion" (a glass half empty view), a gift that is there for the taking.

Such a view of הלק would seem to fit well into the context of double agency as implied by the "enjoy life" refrains. Fox illustrates this relationship between gift and responsibility as it is depicted in the "חלק" concept of "allotment" when he states, "God can give you a piece of the pie, but you must eat it. If you keep it in the cupboard it won't do you any good." ${ }^{91}$ Thus one sees by way of implication that man's חלק is a gift, something that is given graciously by the Creator.

I would suggest that in the "enjoy life" refrains, Qohelet takes this idea of "allotment" one step further, implying that enjoyment itself is man's rל If enjoyment is

${ }^{87}$ Galling, "Prediger," in Die funf Megilloth HAT 18, revised ed., (Tübingen: Mohr, 1969), 89. Lee cites Galling's definition, referring to heleq as "a technical term for 'the space allotted for human existence." "Fox too cites Galling ("[G]eradezu terminus technicus für den der menschlichen zugewiesenen Raum," 89), but criticizes his definition as not demonstrating what is "distinctive about this word" [in Qohelet]. See Fox, A Time to Tear Down, 110.

${ }^{88}$ Ogden understands the term in the sense of "this" worldly as opposed to "other" worldly. See Ogden, Qoheleth, 29.

\footnotetext{
${ }^{89}$ Fox, A Time to Tear Down, 110.

${ }^{90}$ Ibid, 111.

91 Ibid.
} 
a gift from God, and if man's too much to consider enjoyment as the allotment given by God to man. ${ }^{92}$ Noting that enjoyment is clearly referenced as a gift from God, one can see how Brown assumes that enjoyment is one's allotment, the nלp appointed unto a man: "The sage repeatedly refers to enjoyment as one's 'lot' (heleq), something assigned rather than achieved.",93 Provan also understands one's חלק as a gift from God:

The emphasis lies on enjoyment or joy as itself the reward that we may expect from life and all our effort expended at living it. There is no surplus, no profit beyond that. Indeed, the "reward" is itself a gift from God, an inheritance in which we share rather than a prize that we earn (cf. 9:6 for heleq as our "share" [NIV "part"] of life under the sun; also Gen. 31:14; Num. 18:20; Deut. 10:9, etc., for the frequent use of heleq in the sense of inherited land or property). It is in receiving life as a gift from God and in not striving to manipulate it and exploit it in order to arrive at some kind of "gain" that mortal beings can find contentment. $^{94}$

Beyond the assumptions made by the commentators cited above, Lee observes that the preponderance of the second person pronoun in 9:7-10 implies that the object of each (your bread, your wine, your wife, etc...) is in effect describing one's הליק; "Qohelet is in effect proclaiming: 'All of these things are your portion. It has been given to you, and it is yours for the taking and enjoying." $" 95$ Thus, the manner in which Qohelet uses the key

\footnotetext{
92 Ingram observes that in the five occurrences where הלמה is referenced in conjunction with might be assumed that "enjoyment is the הלק in these verses ..." However, he continues by stating that "[O]n three occasions the verses in which roccurs describe the gift of God, but contrary to the claims of a number of commentators, it is not הלק which is described as God's gift . . "I agree with Ingram that the refrains themselves are rather ambiguous as to the subject described as "God's gift" - it could be the "days of one's life" $(5: 17 ; 9: 9)$, the ability to enjoy wealth or possessions, the contentment that might come from one's work, or the very emotion of joy itself - but I disagree with Ingram that gift in the refrains. At the very least, the fact that enjoyment comes as a gift from God allows one to assume that a major component of one's זיז is the gift of enjoyment. See Ingram, Ambiguity, 138-39.
}

\footnotetext{
${ }^{93}$ Brown, "Whatever You Hand Finds to Do," 281.

${ }^{94}$ Provan, Ecclesiastes/Song of Songs, 74.

${ }^{95}$ Lee, Vitality, 68-69.
} 
wליע הלק is not unlike his use of the word's inherent ambiguity denies a precise meaning in Qohelet, especially when occurrences aside from the "enjoy life" refrains are considered. Taking the approach of in-textual multivalency, the term reflects some sense of entitlement to the enjoyment of life, whether it be the time of one's opportunity, the entities given to produce joy, or the enjoyment of life itself. ${ }^{96}$

On the subject of enjoyment as a gift from God, one cannot help but see the correlation between the ability to enjoy life and divine determinacy in the "enjoy life" refrains. Not only do the refrains themselves explicitly refer to enjoyment as a gift from God, but the context in which the refrains are found often bathe the text in the pervasiveness of divine activity. Nowhere is this clearer than in Qoh 3:10-15, where God is portrayed as the "primary Actor," making everything appropriate in its time (3:11), doing that which man cannot perceive $(3: 11)$, acting in the realm of eternity $(3: 14)$, and acting so that man may fear him $(3: 14) .{ }^{97}$ Yet within this passage on divine "doing" lies an "enjoy life" refrain (3:12-13), wherein man is proclaimed as finding "nothing better" than to do something, that is, to enjoy life! However, the human "doing," expressed in terms of enjoyment, is nevertheless made possible by God alone: "it is the gift of God (3:13)." Thus, $3: 13$ echoes the earlier assertion that the ability to 'see good' comes 'from the hand of God' (2:24).

It would be incorrect to think of enjoyment as a gift given in a universal sense without some mystery of divine election attached. ${ }^{98}$ The idea of divine choice and

\footnotetext{
${ }^{96}$ One should note that these connotations really only reflect upon the in-text multivalency as the term is used in reference to the enjoyment of life. Inner (within Qohelet) and inter-textual (within the Hebrew Bible) references broaden the range considerably as alternate contexts drive the meaning of the word.

${ }^{97}$ Lee, Vitality, 40.
} 
inscrutable election is pervasive throughout the text of Qohelet, and it too touches

Qohelet's theology of enjoyment $(6: 1-2 ; 7: 14 ; 9: 11-12)$. While the "gift" of enjoyment

does not seem to be something earned, it does seem that enjoyment comes to the

"righteous" rather than the "sinner" (2:26). ${ }^{99}$ However, the terms "righteous" (בviv, lit.,

"the one who is good") and "sinner" (Nurn, lit., "one who misses the mark") should not in

this context be conceived of in terms of moral righteousness; rather, "in the vocabulary of

the wisdom tradition, the 'חושא' is the bungler, the loser, the one who is always making

mistakes. ${ }^{100}$ Seow continues to elaborate on this thought:

The 'חוטא' is the fool. To such a one, God gives the unpleasant task of gathering and accumulating only to give to the one who is favored. The one who is already in a good position gets all the good things, but the loser loses. The pairing of (the one who does well) and $\mathrm{x}$ (the loser) is reminiscent of Prov 13:22, where the one who is מוב (the loser) hoards possessions only to give them to others. ${ }^{101}$

Thus, couched in wisdom vocabulary, it is for the wise to embrace the wisdom of enjoyment while it is for the fool to strive after ephemeral gain. Nevertheless, Qohelet counsels the wise not to depend upon their righteousness as it pertains to future blessings

\footnotetext{
${ }^{98}$ Of course election in the soteriological sense is certainly not in mind when speaking of this aspect of Qohelet's theology.

${ }^{99}$ On 2:25, Polk states that "[T] $]$ he gift of wisdom, knowledge, and joy is not a chance accident, nor even something resulting subsequently from pleasing God, as a reward for good behavior. Rather, it is a quality that resides in not being "apart from him." While I am apprehensive to embrace his later conclusion (it seems to me a bit Christianized), I do agree that the divine gift of joy is neither an accident nor a reward, but rather, it seems to be based in the inscrutable determinacy of God. See Polk, "The Wisdom of Irony,"12.

${ }^{100}$ Seow, Ecclesiastes, 157-58.

${ }^{101}$ Ibid. The case for understanding Rather, it must be made by leaning on the pervasive and categorical contrast between the fool and the wise in wisdom literature, and even then, can only be justified case by case based upon the context of a particular usage. In references such as Prov 13:22; 19:2 and Qoh 7:26; 9:2, 18 the "sinner" is not being contrasted with the morally righteous, but rather, with the wise. The antithetical correspondence in these references is thus with the fool, not the morally unrighteous. However, even in wisdom literature this understanding is dependent upon context. For instance, in Qoh 7:20, the contrast is likely based in morality, not wisdom.
} 
and the potential for the enjoyment of life-one's days are not guaranteed in the future realm (7:15-18;9:11-12). The mystery of divine "approval" is one that is never resolved in Qohelet's theology, not in the realm of judgment or in the realm of provision and enjoyment. ${ }^{102}$ However, as a response, Qohelet does not settle for the despondency of cynical dismay, but rather, he embraces the path of wisdom as the means to the enjoyment of life. ${ }^{103}$

\section{The Wisdom of Joy}

Qohelet begins and ends his reflections with the indictment that everything is and the "enjoy life" refrains are not exempt from such a judgment. Qohelet does not find תרון, but he does find the שמח the enjoyment of life. ${ }^{104}$ He cannot redeem the reality of a fallen world, but he does present a divinely endorsed alternative to vexation of spirit-the enjoyment of life. ${ }^{105}$ However, it is only through wisdom that the exercise of joy is ever realized and appropriated to one's life.

There are many reasons that one should enjoy life, not the least of which being present self-interest. However, Qohelet looks to the future for motivation, suggesting that for the wise the inevitability of death should function as the most potent of motivators in

\footnotetext{
${ }^{102}$ In a sense, it may be said that "God the problem is also God the answer." This is perhaps best displayed in the apparent irony between the vexing preoccupation (inyan) man is burdened by $(3: 10)$ and the positive preoccupation of joy that God provides $(5: 20)$. Seow sums up the irony well: "The deity who vexes is the very One who responds to humanity's plight with an answer: the possibility of enjoyment, however fleeting it may be." See Seow, "Theology When Everything is Out of Control," 245.

${ }^{103}$ While it is true that there are innumerable things over which humans have no control (this is one of the major tenets of Qohelet's "theological anthropology"), there nevertheless is the potential to appropriate joy through the free exercise of wisdom. Lee states it best when she writes, "Yet, over the means of enjoyment, human beings do have the God-given power of disposal, if only for a given moment, and Qohelet urges the vigorous and responsible exercise of that power (Lee, Vitality, 47)."

${ }^{104}$ It should be noted that the very temporality of הלק serves. to motivate the wise to the appropriation of present enjoyment. See Lee, Vitality, 43.

${ }^{105}$ Gianto, "The Theme of Enjoyment in Qohelet," 531.
} 
the appropriation of present joy. Indeed, as is the case with the motif of divine determinacy, so too the "enjoy life" refrains are often set within the immediate context of the inevitability of death (note esp. $3: 19-21 / 3: 22 ; 5: 15-17 / 5: 18-20 ; 9: 2-6,10 / 9: 7-9$; 11:10b - 12:7/11:9-10a). ${ }^{106}$ While many scholars view Qohelet's preoccupation with death in the most negative of terms, a more balanced approach is to see the inevitability of death as the wise man's prod to action. Death is without doubt an awful reality, and while Qohelet does little to soften its sting in theological terms, he nevertheless takes a practical approach that shifts the emphasis from the negative to the positive. Furthermore, as the depth of rhetoric increases on the inevitability of death (certainly one senses a rhetorical climax on the theme in $9: 2-5,10$ and $12: 1-8$ ), so too the imperative urgency increases in Qohelet's exhortation to embrace life and to make the most of every opportunity. ${ }^{107}$ And so Qohelet's urges the wise to "seize the day" before the opportunity is lost to the inevitable day of one's death.

Enjoyment for Qohelet is not a matter of "more is more," as a matter of fact, Qohelet's wisdom warns against the folly of such thinking $(2: 20-23 ; 4: 4-6,8 ; 5: 10-15$; 6:7-9). Enjoyment is realized in the simple pleasures of life, and in a sense, the attitude of contentment is crucial to the appropriation of enjoyment. However, one must understand what contentment does and does not entail. While it may be true that Qohelet speaks of the folly of gain in light of the curse of life's hevelness, it is incorrect to think that

${ }^{106}$ Ogden recognizes the inter-dependency and prominence of these two motifs, stating that "... the call to enjoyment and concurrent reflection on the inevitable future of humanity in death, is indeed the central theme of the book." See Ogden, "Qoheleth XI 7 - XII 8: Qoheleth's Summons to Enjoyment and Reflection," VT 34 (1984): 38. See also Lee, Vitality, 56: “. . when Qohelet reflects on the inevitability of death, he does so in order to motivate people to embrace life all the more (see $3: 3: 19-22 ; 5: 14-19 ; 9: 5-10$; 11:7-12:8)."

${ }^{107}$ Commenting on the exuberance of 9:7-10, Lee writes, "It is as if the awful contemplation of death stirs him to embrace life all the more and to urge his audience to do the same (Lee, Vitality, 62)." I would suggest too that this observation applies equally well to 11:7-12:8. 
contentment equals complacency in Qohelet's theology of enjoyment. To the contrary, Qohelet urges his readers to make the most of every opportunity, to be fully engaged in the present, and to "seize the day" as a gift from God, knowing that there is no guarantee of the future $(9: 7-10)$.

The carpe diem wisdom in Qohelet's "enjoy life" refrains has little to do with a denial of present responsibility or future reckoning. To the contrary, Qohelet's admonition is refreshingly sensible in today's world. It simply teaches that "true wisdom encompasses the sense to enjoy in the present that which can be enjoyed." 108 In light of the pervasiveness of Qohelet's conclusions to enjoy life, it is indeed ironic that Qohelet has been read as an endorsement of the ascetic life. ${ }^{109}$ Asceticism is the furthest thing from Qohelet's mind-if confronting the ascetic, there is little doubt that Qohelet would label such a fool. For Qohelet, enjoyment is the co-equal apex of wisdom; ${ }^{110}$ it is certainly not a peripheral issue. On the pragmatic impact of Qohelet's "enjoy life" conclusions and their influence upon the human psyche, Lee writes, "He repeatedly draws the conclusion that enjoyment is humanity's most urgent responsibility because it both reflects the divine will and addresses the deepest human needs." $" 111$

Enjoyment is at once the most responsible and reasonable answer to the inevitability of death and the hevelness of one's own life. ${ }^{112}$ It is a wisdom that gives

\footnotetext{
${ }^{108}$ Frydrych, Living under the Sun, 74.

${ }^{109}$ Lee, Vitality, 128.

${ }^{110} \mathrm{I}$ will argue in the following two chapters that the "fear of God" motif functions as the balance to the enjoyment of life, the other side of the "two sided wisdom coin."

${ }^{111}$ Lee, Vitality, 126.

${ }^{112}$ Ibid, 44, 58.
} 
profound value to the present while not losing sight of the future. ${ }^{113}$ Qohelet's theology of enjoyment is centered upon present opportunity, but in the pragmatism of the wisdom imperative, its focus centers most poignantly upon the days of one's youth. The beauty of such teaching, however, is that the carpe diem reality of life in the present, indeed, life within the days of one's youth, is equally balanced between enjoyment and accountability (11:9-12:1). In the interest of presenting the other side of Qohelet's wisdom, we now turn to the "fear God" motif.

${ }^{113}$ The future provides Qohelet with the necessary motivation for the present, yet his understanding of the future is not without a sense of responsibility. Qohelet knows little about the future, but does seem to understand that he will one day answer for his actions as they are conducted in the present (3:17; 12:1; 12:13-14). So while Lee is accurate in stating that "Qohelet allows no world beyond this to justify a flight from the responsibility of the present," this is only true in reference to the enjoyment of life. The other side of the coin, the responsibility to live holy before the God of creation, seems to be greatly prompted by the knowledge (however vague) of a "world beyond this." See Lee, Vitality, 129. 


\section{CHAPTER 8}

\section{WHAT WILL THE WISE MAN DO? THE FEAR OF GOD CONCLUSIONS IN THE BOOK OF QOHELET}

Derived from Qohelet's observations of life in a הבל world, the two-fold response admonishing the enjoyment of life and the fear of God function together to provide a balanced paradigm for living in expectation of the inevitability of death. ${ }^{1}$ However, at first glance, one may tend to see these two as incompatible. All too often, hedonistic excess is read into the first admonition and pietistic asceticism into the other-two ideas that are at the very least in tension with each other, and at the most in irreconcilable contradiction. As is so often the case with Qohelet, scholars are divided over how one should read these motifs, and few have developed any explanation regarding how the two should be read in relationship to one another. Often the situation is resolved by elevating one conclusion to a prominent role, while diminishing the other to obscurity. However, there is absolutely no indication within the text itself that either one of these motifs should be dismissed as a lesser consideration. Both of these motifs are presented as imperative conclusions in Qohelet's rhetoric, and as such, it behooves us to understand their relationship to each other if we are to ultimately understand the message of the book itself. Prior to understanding this relationship, however, we must first establish the fear of

\footnotetext{
${ }^{1}$ As I present these two motifs, I do so using the verbal imperative much as it is communicated within the text of Qohelet. It is worth noting that the fear of God is only communicated within Qohelet in the verbal form, never in the nominative $(3: 14 ; 5: 6 ; 7: 18 ; 8: 12,13 ; 12: 13)$. As with joy, Qohelet does not discuss the "fear of God" as a philosophical or theological construct; rather, he commands it as a wisdom imperative.
} 
God as motif, and in doing so, come to an understanding of its breadth and nature in Qohelet's wisdom rhetoric.

\section{Remembering One's Creator-The Centrality of the Fear of God in Qohelet}

As with other motifs and catch-phrases in Qohelet, scholarship is divided as to the role and nature of the "fear God" motif in Qohelet's wisdom rhetoric. On the one hand, scholars who take a source critical approach to the book are quick to assign these injunctions to the work of a pious redactor. ${ }^{2}$ On the other hand, those who take a more unified, yet no less pessimistic approach to the book, are inclined to view the fear of God in Qohelet's thought as the literal dread that comes with being terrorized by an all powerful, inscrutable deity. ${ }^{3}$ Finally, others see in these injunctions variously nuanced notions of piety similar to that found in proverbial wisdom (Prov 1:7), thus allowing the motif to influence the final approach to the book in a positive and more canonically compliant way.

As to the role and position of prominence played by the "fear God" motif, Franz Delitzsch has famously called the book of Qohelet the "supreme song of the fear of God" and the "quintessence of biblical piety." Lohfink has likewise attributed to the "fear of

\footnotetext{
${ }^{2}$ Older source critical commentaries dismissed all references to the fear of God and righteous judgment as the work of any number of "pious redactors;" however, such an approach is still taken by many respected scholars today. For older works, see Carl Siegfried, Prediger und Hoheslied. HKAT (Göttingen: Vandenhoeck und Ruprecht, 1898); A. H. McNeile, An Introduction to Ecclesiastes (Cambridge: Cambridge University, 1904); G. A. Barton, A Critical and Exegetical Commentary on the Book of Ecclesiastes, ICC (Edinburgh: T \& T Clark, 1912). For an example of a popular newer work taking this approach, see Crenshaw, Ecclesiastes.

${ }^{3}$ Walther Zimmerli, “Das Buch des Predigers Salomo," Spruche/Prediger (ATD 16/1; Göttingen: Vandenhoeck \& Ruprect, 1962), 174. See also Elias J. Bickerman and his well known understanding that for Qohelet, the fear of God has come to be an admonition to "be on guard against Elohim." Elias J. Bickerman, Four Strange Books of the Bible: Jonah, Daniel, Koheleth, Esther (New York: Schocken Books, 1967), 149.

${ }^{4}$ Delitzsch, Ecclesiastes, 183.
} 
God" a central place of prominence in Qohelet's message, ${ }^{5}$ yet others continue to relegate the "fear God" motif to a place of obscurity, overshadowed by the more pressing reflections of a skeptical pessimist who is unsure of any value that might be attached to the fear of God. ${ }^{6}$ However, the fear of God, as it relates to Qohelet's rhetoric, cannot be dismissed as the interpolations of a pious redactor, or the inconsequential musings of a troubled mind. The motif is simply too well integrated into the context and syntax of the book to have been added by those seeking to bring the text into conformity with the precepts of "traditional wisdom." Furthermore, the fact that the motif takes the form of verbal imperative throughout the text argues strongly against these being the musings of reflective activity. Rather, the fear of God functions as an aspect of Qohelet's conclusions reached after reflection has taken place; they are not the by-product of Qohelet "thinking out loud." More so, as imperatives, they are never once contradicted or repealed by the text. Concerning the attempt by some to remove the fear of God as a substantial aspect of Qohelet's wisdom, Lee correctly makes the observation that "[T]o excise this critical motif in an ad hoc fashion would be to undercut the theological and ethical claims of the book." The overall message of Qohelet must be understood as reflecting the kind of wisdom that calls for the fear of God. The conclusions are simply too clear and the motif is simply too well integrated into the whole to dismiss this theme as being anything less than one of the essential motifs integral to the message of the book.

\footnotetext{
${ }^{5}$ Lohfink, Qoheleth, 3, 9.

${ }^{6}$ See for instance Anderson, who attributes the "fear God" imperatives, much as he does the "enjoy life" imperatives, to the literary function of being nothing more than "pessimistic tropes." See Anderson, Pessimistic Theology, 113-16.

${ }^{7}$ Lee, Vitality, 84 .
} 
Qohelet does not explicitly equate the fear of God with wisdom or the "beginning of wisdom" (Prov 1:7), yet throughout the book the verbal injunction to fear God is communicated in such a manner that one senses that this theme is an essential aspect to Qohelet's understanding of what it is to "be wise." Frydrych senses something of this notion when he states that "although Qoheleth never uses the popular wisdom saying found in Proverbs and elsewhere that the fear of God is the beginning of wisdom, he makes it quite clear that not fearing God is an act of sheer madness!" ${ }^{8}$ Thus, at the very least, the fear of God functions in Qohelet's wisdom as a cautionary measure against the potential pitfalls of folly. In spite of the vexation brought about by Qohelet's observations regarding the inequity of justice $(3: 16 ; 8: 12,14)$ and the impotence of wisdom $(2: 12-16$; 8:16-17), Qohelet nevertheless warns against the folly of living as if God is unconcerned with personal sin and unrighteousness $(3: 17 ; 7: 15-18 ; 8: 12-13) .{ }^{9}$ Although righteous living may not guarantee prosperity and blessing, only a fool would live as though God were altogether uninvolved or unconcerned; to do so would be to court one's own destruction.

The "fear of God" motif in Qohelet functions not only as a pragmatic safety net for living in a הבל world, it also has a more profoundly theological dimension linked to the inscrutable nature of God's activity. This can be seen implicitly in the references

\footnotetext{
${ }^{8}$ Frydrych, Living under the Sun, 111.

${ }^{9}$ It should be noted that the approach to Qoh 7:15-18 presented in chapter 4 is contrary to Lee, who states that "Qohelet makes the surprising claim that genuine piety inevitably includes a measure of wickedness and folly, for such is the reality of the human condition. His faithful realism leads to a form of piety that is more modest (and less demanding), and therefore more able to instill life in those who would pursue it. (Lee, Vitality, 103)." Lee's approach seems to conform more to the philosophy of a Golden Mean (despite her denial of such; p. 103) rather than the Hebraic notion of cultic piety and obedience implied elsewhere in "fear of God" imperatives, including those in Qohelet $(5: 6 ; 12: 13)$ and Deuteronomy (5:29; $6: 13,24)$. Such an approach seems to be contrary to Lee's view on the unity of Qohelet and the notion of following God's commandments found elsewhere in her otherwise excellent work.
} 
addressed above $(7: 15-18 ; 8: 12-14 ;$ tied to the inscrutable deployment of justice), as well as in the more explicit reference to the fear of God in 3:14: "I know that everything God does will remain forever; there is nothing to add to it and there is nothing to take from it, for God has so worked that men should fear Him." ${ }^{10}$ As Qohelet proceeds to explicate the vast differences between the inscrutable Creator and the impotent capacity of mankind to "know" (3:11-15), he touches upon the appropriate response of mankind in light of this vast chasm: the fear of God (3:14). Whether this response should come as a result of man's "awareness of divine superiority," the relationship between God and man, ${ }^{12}$ the conclusion is much the same: to fear God is to recognize and respect the distance between the divine and human. ${ }^{13}$ It is not the immanent hand of judgment that provides the primary impetus for Qohelet to commend the fear of God, although the possibility of such is certainly influential in his wisdom, but rather, it is his awareness of the transcendent God that compels him to fear God in spite of the apparent lack of divine activity in meting out justice $(3: 16)$. As a starting point in understanding the "fear God" motif, Lee is correct in stating that "Qohelet's discourse on

${ }^{10}$ Qoh 3:14, NASB.

${ }^{11}$ Frydrych apparently understands this relationship as that of result and effect, stating that "the fear of God derives from the awareness of the divine superiority; it is the awareness and acceptance of the qualitative divide between God and the human race." While Frydrych does not explicitly deny design and purpose as inherent in this relationship, I would suggest that the text implies an element of purpose and divine design in this divide. See Frydrych, Living under the Sun, 110.

${ }^{12}$ Polk touches upon the inherent purpose and design in this great divide, noting that "God has made man finite and placed him in a world that forever must remain a mystery to him," even though "God has planted in man an inexorable striving to understand that mystery." Nevertheless, this "irony" came not by happenstance, but rather, by design, "for he has made things "so that men should fear before him." Thus, in Polk's view, this "hevel" situation was designed for a "positive resolution, so that man might come into a "proper relationship with God." See Timothy Polk, "The Wisdom of Irony," 15.

${ }^{13}$ Lee, Vitality, 85 . 
fearing God is firmly rooted in a theology of divine transcendence" and that "[I]t is this essential Otherness of the deity that elicits humanity's response of 'fear.",14

Qohelet further links the fear of God to the recognition of divine "Otherness" in his exhortation to fear God in the practice of cultic ritual (5:1-7 [Hebrew 4:17-5:6]). ${ }^{15}$ In the presence of the divine, Qohelet calls the divide between divine and mortal into reflection: "God is in heaven, and you are on earth, so let your words be few (5:2b [Hebrew 5:1b])." Although the only call to fear God comes at the close of the segment, the pervasiveness of reverence in Qohelet's wisdom on ritual practice is clear throughout. ${ }^{16}$ For this reason, the ad hoc approach of critical scholars to attribute $5: 7 \mathrm{~b}$ (Hebrew 5:6b) to the hand of a "pious" redactor is unjustified; ${ }^{17}$ the "fear God" imperative closing this segment (as well as the whole segment in general) falls quite in line with the context, and the lexical/rhetorical similarity of this passage to the rest of the book argues strongly for its integrity. ${ }^{18}$

As to the meaning of the "fear God" imperative in this context, viewed from the similar theological basis seen in 3:14, it is safe to assume that the call to "fear" is one of

${ }^{14}$ Ibid.

${ }^{15}$ References in the follow segment will default to the English.

${ }^{16}$ Although Qohelet does not focus on cultic ritual in his wisdom, it is clear that he is not ignorant of its place and practice within society. The greater literary divide at this segment is not in reference to the topic of 5:1-7, but rather, the shift in mood from indicative to imperative. Castellino identifies this segment as the front end of an inclusion completed by the "fear God" imperative in the epilogue, and notes that this shift in mood marks the primary division of the book. See Castellino, "Qohelet and His Wisdom," 16-17.

${ }^{17}$ See Michel, Untersuchungen zur Eigenart des Buches Qohelet, Beihefte zur Zeitschrift fur die alttestamentliche Wissenschaft 183 (Berlin: de Gruyter, 1989), 257; Barton, Ecclesiastes, 123-24; Galling, "Der Prediger," 76; Gordis, Koheleth, 101, 248; Aarre Lauha, Kohelet, Biblischer Kommentar: Altes Testament 19, (Neukirchen-Vluyn: Neukirchener, 1978), 97.

${ }^{18}$ Note the use of vocabulary peculiar to Qohelet (עין [Hebrew 5:2]) or characteristic of Qohelet (b=- [Hebrew 5:6]). Also, one finds rhetoric that while not unique to Qohelet, is quite characteristic of the book (for instance, the "better-than" saying in 5:5 [Hebrew 5:4]). 
appropriate reverence, not "fearful foreboding," but a "strong cautionary word against relating to God in a casual manner," 19 the implied point being that to do so would be anything but wise. Lee is correct in observing that the emphasis on reverence in this text is not unlike the respect for God that is commanded elsewhere in the Old Testament, ${ }^{20}$ and thus it is inappropriate to read "terror" into Qohelet's conception of fear in a sense unlike what is espoused elsewhere in the Old Testament.

The primary thrust in this passage, however, is not to comment on the proper attitude in the practice and procedure of Israel's cult, nor to elaborate in a systematic way upon the divide between God and man (God is not unconcerned about human affairs, if anything, this text suggests that he is even concerned with the minutia of cultic ritual), but rather, to demonstrate the way in which a wise man should approach God in light of the great "Otherness" of the Creator. In a similar fashion, Qohelet calls the wise man to "remember" his Creator in the days of his youth; to live in one's youth apart from cautionary reflection would be to court the same folly indicative of irreverence in ritual sacrifice. And thus we come to consider an imperative that functions contextually as a near synonym to the "fear God" imperatives, the call to "remember your Creator in the days of your youth" $(12: 1 a) .^{21}$

${ }^{19}$ Elaborating upon the nature of this "strong cautionary word," as it relates to the cult, Lee perceptively writes, "The fear of God is properly demonstrated, not by the offering of sacrifice, prayers, and vows, but by the exercise of appropriate restraint and reverence when doing so." See Lee, Vitality, 9495 .

\footnotetext{
${ }^{20}$ Lee cites admonitions from within Qoh 5:1-7 with corresponding references in other Hebrew wisdom texts: "(1) thoughtful and restrained speech (5:1-2; cf. Prov 10:14, 19; $21: 23 ;$ Eccl 6:11;10:13-14), and (2) accountability for vows (5:3-5; cf. Prov 20:25; Sir 18:22; Ps 66:13-14)." She also notes the precise parallel in Deut 23:22-24 to Qohelet's admonition concerning vows. She concludes by stating, "There is no warrant for arguing that Qohelet's conception of fear in this text represents a perverse re-imagination of this biblical principle. See Lee, Vitality, 93-95.

${ }^{21}$ As with the "fear God" imperative in 5:7, so too critical scholars have sought to excise the imperative of 12:1a from the text. However, textual and linguistic evidence argues against such excision.
} 
Structurally, the call to remembrance (12:1a) functions as an imperative balance to the call to enjoyment $(11: 9-10) .^{22}$ For this reason, it is unfortunate that many commentators seek to eliminate this necessary balance by emending "Creator") to בורר ("well, cistern"; either approximating the "grave" or understood on the basis of Prov 5:15 as a metaphor for "wife"). ${ }^{23}$ Crenshaw, for one, adopts the view that this imperative is "more probably" a call to remember one's wife, an imperative that "urges young people to reflect on the joys of female companionship before old age and death render one incapable of sensual pleasure. ${ }^{924}$ He comes to this conclusion not on strong textual evidence, but rather, on the a priori assumption that any reference to "remembering" or "fearing" God must not be original to Qohelet. ${ }^{25}$ Astonishingly, regarding 12:1a, Crenshaw states that an "allusion to God the Creator ill fits this context." ${ }^{26}$ However, one

Although not opposed to source critical approaches to Qohelet, Kruger writes, "Therefore there is, in my opinion, no literary-critical reason from the standpoint of content to exclude 12:1 a as an 'orthodox' gloss (thus, e.g., Galling; Lauha; Michel). This would also require a striking of 11:10b, since 12:1b cannot be connected with $11: 10 \mathrm{~b}$. Speaking against this is the fact that both verses are firmly anchored in their context by various key-word relationships. The key words 'rejoice' and 'think about' from 11:8 are taken up again in 11:9a ('rejoice') and 12:1 a (think about'). Verses 11:10b ('fleeting') and 12:1b ('approach, come') hark back to $11: 8 \mathrm{~b}$ ('all that comes is fleeting'). And 11:10b ('youth') and 12:1a ('days of your youth') pick up the corresponding key words from 11:9a. This web of key words, which can hardly have arisen by pure accident, would be destroyed by the exclusion of 11:10b-12:1a." See Kruger, Qoheleth, 198.

22 Bartholomew, Reading Ecclesiastes, 250.

${ }^{23}$ Seow, while concluding that the word should best be translated "your Creator," also acknowledges the possibility that Qohelet, given his penchant for wordplays, may have intentionally sought to evoke other connotations in using this word ("it seems likely that he might have intended his audience to hear more than one meaning in a word"). Seow cites too the oft referenced interpretation of Rabbi Akabya that takes into account three different Hebrew words: "ברורך, "your source (from whence you came), 'your pit' (whither you are going), and בפרדאך 'your creator." "For a thorough treatment of the textual and linguistic issues involved in Qoh 12:1a, see Seow, Ecclesiastes, 351-52.

${ }^{24}$ Crenshaw, Ecclesiastes, 185.

${ }^{25}$ While emendation is always a possibility, the textual and contextual evidence argues against it. Regarding the textual evidence, Seow states, "If the consonantal text is correct, as all the witnesses attest, it is difficult to think that something other than 'creator' is the primary meaning [of בּוֹא ]." See Seow, Ecclesiastes, 351. 
must ask on what logical grounds can Crenshaw make such a statement? The logic of recalling one's Creator in this context is quite compelling, as noted by M. Gilbert:

Thus, in order to recall death, Qoheleth refers to creation. The circle is complete: the end is tied to the beginning. Hence one should not be astonished to see in 12:1 an explicit mention of the creator. Remembrance of him does not mean a return to the past in which one began but calls attention to the end in which the ruah given in the beginning will return to the one who gave it. ${ }^{27}$

Actually, it should come as no surprise that Qohelet would complement one motif with another, even if there is a certain tension between these motifs. For instance, while death and the fear of God would seem to go hand in hand (as cited by Gilbert), there are other motifs within this context that are not quite as easily matched, yet in context the tension is one of balance and compatibility. Just such a tension is evidenced by the balance between the enjoyment of life and the judgment of God referenced in 11:9: "Be happy, young man, while you are young, and let your heart give you joy in the days of your youth. Follow the ways of your heart and whatever your eyes see, but know that for all these things God will bring you to judgment. ${ }^{28}$ Garrett summarizes this necessary balance between the enjoyment of life and the fear of God in a succinct manner: "Awareness of divine judgment turns the pursuit of joy away from crossing over into sins." ${ }^{\prime 29}$ It is therefore not surprising that the text should proceed to call for one to remember the Creator in the days of one's youth, for only in following such wisdom is one protected from the folly of confusing the enjoyment of life with sinful living. Understanding 12:1a to be a logical imperative based upon the knowledge of coming

${ }^{26}$ Ibid, 184.

${ }^{27}$ As cited by Murphy, Ecclesiastes, 117. See also M. Gilbert, "La description de la vielliesse en Qohelet XII 1-7 est-elle allegorique?," Congress Volume, Vienna, 1980. VTSup 32, (Lieden: Brill, 1981), 100.

\footnotetext{
${ }^{28}$ Qoh 11:9, NIV.

${ }^{29}$ Garrett, Proverbs/Ecclesiastes/Song of Songs, 340.
} 
judgment (11:9b), ${ }^{30}$ Garrett concludes his treatment of Qoh 12:1 a noting the essential

balance between the enjoyment of life, the fear of God, and the practice of wisdom:

Nor is the exhortation to remember the Creator a contradiction to the exhortations to rejoice. Instead we have a warning against mindless self-indulgence and profligacy during the days of one's vigor. To forget the Creator of youth is to invite bitter regrets and an empty existence in old age. To remember the Creator is to follow the path of wisdom and extend the joy of life. ${ }^{31}$

It is equally notable that the remembrance of God functions as an introduction to Qohelet's most striking reflections upon the inevitability of death (12:1b-7), which too concludes with a clear allusion to the Creator (12:7b, "and the spirit returns to God who gave it"). There is little doubt that Qohelet is using his final and most profound reflections upon the inevitability of death to call his readers to remember God while the opportunity exists. This is as much a thematic imperative to live in the present as is the call to enjoy life while one has the opportunity (see especially 9:7-10). However, while one may concede that $12: 1$ a could be understood as a call to seize the opportunities granted by God for enjoyment, ${ }^{32}$ it is more likely that this is an exhortation to balance that enjoyment through the sobriety that comes knowing of the inevitability of death and the presumption of personal eschatological judgment. ${ }^{33}$ With this in mind, we turn now to

\footnotetext{
${ }^{30}$ On the role of personal eschatological judgment as a motivating factor in the fear God imperatives, see the subtitle in this chapter, "Fear of God and the Appointed Time of Judgment."

${ }^{31}$ Garrett, Proverbs/Ecclesiastes/Song of Songs, 340 - 41.

${ }^{32}$ Kruger, Qoheleth, 198. The idea of remembering the God who brings enjoyment is thought by some as nearly synonymous with the idea of taking up joy as an ethical responsibility to the Creator - in this sense, enjoying life is remembering God. Lee for instance sees the enjoyment of life as the vital means to express the fear of God. Personally, I prefer to see the two in relationship besides each other, or practiced alongside one another. The one should not be understood as a representation of the other. See Lee, Vitality, 85-86.

${ }^{33}$ Note that sobriety in remembrance is not foreign to Qohelet's thoughts on the enjoyment of life. As a matter of fact, 11:8 ("However many years a man may live, let him enjoy them all. But let him remember the days of darkness, for they will be many...") appears to mirror the larger segment of 11:9$12: 7$, in a sense introducing the segment in summary form.
} 
the "postscript" and afterwards, the question of personal, eschatological judgment as rationale for the fear of God.

\section{The Fear of God and the "Whole of Man"}

As suggested in chapter one, commentators are divided over the role, authorship, and origin of the so-called "epilogue" and "postscript" to the book of Qohelet. ${ }^{34}$ This comes up now as a point of interest due to what Franz Delitzsch called "the kernel and star of the whole book," the final imperative to fear God and keep his commandments (Qoh $12: 13) .{ }^{35}$ Here, the "fear of God" comes not as the beginning of wisdom, but rather, it stands as its $e n d,{ }^{36}$ thus functioning to bring the book of Qohelet to a close by drawing the attention of the reader back to the motif only previously referenced in relative obscurity. ${ }^{37}$ So, in closing "with the words of Torah," ${ }^{938}$ the postscript has been variously seen as reinforcing and validating the teachings of the whole book, or viewed as a corrective to Qohelet, in a sense setting the record straight for the sake of both canon and reader. In either case, the importance of the imperative is unquestioned; after all, the judgment of the writer is that it encompasses the "all of man" (של־דארם).

\footnotetext{
${ }^{34}$ The epilogue is typically viewed as Qoh 12:9-12, while the postscript pertains to Qoh 12:13-14. Commentators, however, are not always in agreement regarding these designations, with many choosing to view the epilogue as a single unit encompassing Qoh 12:9-14, or with others separating the epilogue between 9-11 and 12-14 (each unit then beginning with רית; see Murphy, Ecclesiastes, 124). For an excellent overview of commentators who affirm a single hand in the epilogue, two separate hands in forming an epilogue and a postscript, and the rationale behind the various approaches, see Murphy, Ecclesiastes, 126-130 and Fox, A Time to Tear Down, 363-77.

${ }^{35}$ Delitzsch, Ecclesiastes, 438.

${ }^{36}$ Kruger, Qoheleth, 214.

${ }^{37}$ That is, relative to the prominence given to other motifs such as the hevelness of life (heightened through the use of the superlative and framed by inclusio) or the enjoyment of life (heightened to prominence through the escalation evidenced by repeated refrains).

${ }^{38}$ Cited by the rabbis (b. Shab. 30b).
} 
This judgment too has been variously translated and interpreted. Some have viewed the statement as descriptive of what is universally true (or required) of man, a kind of self evident general revelation that transcends the cult of Israel and extends to the whole of mankind. ${ }^{39}$ Others see the statement in a holistic fashion, understanding that the fear of God encompasses the whole person, everything that entails being truly human and created in the image of God. ${ }^{40}$ Thus, what is prescribed (the fear of God and obedience to his commandments) is then described as encompassing the totality of life. Still others view the statement as implying a prescriptive sense; in other words, the fear of God and obedience to his commandments entails the whole "duty" of man. ${ }^{41}$ Whatever the true intention behind this rather enigmatic phrase, ${ }^{42}$ it clearly functions to highlight the place and significance of the fear of God in Qohelet's wisdom.

Unfortunately (and perhaps ironically), because 12:13 stands "in conclusion to the matter," scholars continue to debate its authenticity, and thus its role and significance in Qohelet's wisdom theology is often diminished. While some view the epilogue and the postscript as coming from the hand of the same author as the rest of the book, ${ }^{43}$ most view Qoh 12:9-14 as the work of a secondary author (and of course some see more than one hand at work in Qoh 12:9-14). ${ }^{44}$ Crenshaw for one sees the combination of the "fear

${ }^{39}$ See for instance Lee, Vitality, 114-15 and Kruger, Qoheleth, 214-15.

${ }^{40}$ Kaiser, Ecclesiastes, 14-15.

${ }^{41}$ Gordis, Kohelet, 355. See also the somewhat interpretive translation of the NIV which follows this track: "for this is the whole duty of man."

${ }^{42}$ Scholars seem to agree that this phrase is probably an idiom in Hebrew whose full meaning is lost in time and translation. See Longman, Ecclesiastes, 282.

${ }^{43}$ See Kaiser, Ecclesiastes, 15, who implies Solomonic authorship throughout the book, including in the epilogue ("surely the author's estimate of his own labor," italics mine). 
God" imperative and the injunction to obedience as "alien to anything Qohelet has said thus far," 45 while others see the words of the "second wise man" as a corrective to Qohelet's own lack of conviction regarding the precepts of traditional wisdom. ${ }^{46}$ Newsome is perhaps most adamant about the perceived disjunction between the postscript and the rest of the book, stating that the postscript is the "first (and not altogether innocent) 'mis-reading' of Qohelet."47

However, many scholars who understand Qoh 12:13 as coming from a "second hand" nevertheless view the postscript as essential to if not compatible with the message of the rest of the book. Fox takes an approach of marked concession, stating that "the postscript is probably by a later scribe, but it now belongs to the book ...,"48 while Seow affirms that while the work of another, $13 \mathrm{~b}-14$ is nevertheless not contradictory to the rest of the book." ${ }^{49}$ Kruger also affirms the general continuity between the postscript and the main text, stating that "[T]he 'ideology' and 'perspective' of vv.13-14 is in no way totally

${ }^{44}$ For a detailed treatment regarding multiple authorship within the epilogue, see Fox, $A$ Time to Tear Down, 363-77.

${ }^{45}$ Crenshaw, Ecclesiastes, 192. Murphy too takes an approach of general discontinuity between the main text and the postscript, writing, "The epilogue is obviously putting forth an ideal which has been developed elsewhere and which is not a concern in Ecclesiastes." See Murphy, Ecclesiastes, 126.

${ }^{46}$ Longman, Ecclesiastes, 281-83. While Longman acknowledges that Qohelet has made reference to the fear of God within the body of his wisdom, Longman claims that he has done so with "doubtful conviction," and thus the epilogist (the "second wise man") is forced to provide the corrective.

${ }^{47}$ As cited by Lee, Vitality, 112. See Carol A. Newsome, "Job and Ecclesiastes," 189-90, in Old Testament Interpretation: Past, Present, and Future, ed. J. L. Mays (Nashville: Abingdon), 1995.

${ }^{48}$ Fox continues to imply an approach of concession by writing, "The book now says: Even if everything is absurd, nevertheless we must fear God and keep his commandments." It is also noteworthy that Fox himself has apparently changed his view regarding the authorship of the epilogue and postscript, suggesting at one time that the whole book was authored by a "frame-narrator," but later suggesting that the postscript came by way of a later scribe. See Fox, A Time to Tear Down, 144 and Fox, "Frame-Narrative and Composition in the Book of Qohelet," HUCA 48 (1977), 83-106.

${ }^{49}$ Seow, Ecclesiastes, 395. 
foreign to the rest of the book of Qoheleth." ${ }^{50}$ Taking this one step further, however, I

would suggest that the postscript is intricately tied to the main text, no matter what theory of authorship one takes regarding Qoh 12:9-14 (although thematic and syntactical correspondence is certainly a strong line of evidence in favor of unified authorship). ${ }^{51}$ Syntactically, the command in $12: 13 \mathrm{~b}$ is identical to that in $5: 6 \mathrm{~b}$ [Hebrew $5: 5 \mathrm{~b}$ ], while the context of guarding one's conduct in the presence of God is thematically similar to that of obeying the commandments of God (5:1 [Hebrew 4:17]; 12:13b). ${ }^{52}$ The "additional" emphasis of divine commandments is indeed not as "foreign" to the mind of Qohelet as many have suggested. ${ }^{53}$ Based upon the thematic prevalence of the fear of God throughout all of the book, not to mention syntactical similarities and the canonical acceptance of the "whole" book, one would be selectively inconsistent to read this final

\footnotetext{
${ }^{50}$ Kruger, Qoheleth, 213. Kruger, who is certainly not opposed to theories of redaction and multiple authorship, nevertheless comes to an appropriate and balanced approach to the postscript when he writes, "Whether the work of an author or editor, 12:13-14 should be understood as a defense of the wisdom of Qoheleth (Kruger, Qoheleth, 215)."

${ }^{51}$ I would again affirm that Iain Provan's approach to the issue of authorship is strongest, suggesting that the "words" of Qohelet are selectively chosen, arranged, and adapted by an anonymous author, who reveals himself only occasionally $(1: 1 ; 7: 27 ; 12: 9-14)$. I find it interesting that Fox calls attention to the correlation between $3: 17 ; 11: 9$ and 12:14 (this "recalls"), yet he still views the writer and the function as separate between the main text and the postscript. In my opinion, such a correspondence is better explained through a theory of unified authorship. See Provan, Ecclesiastes/Song of Songs, 26-31, 226 and Fox, A Time to Tear Down, 363.

${ }^{52}$ Lee notes that "even in Qohelet's explication of religious duty in 4:17-5:6, there are already references-both implicit and explicit-to the commandments (Deut 23:22-24; Num 15:22-31; Lev 4:2, 22, 27-30)." See Lee, Vitality, 113-14.

${ }^{53}$ Longman for instance states that "Qohelet never so admonished his students (Longman, Ecclesiastes, 282)," but Fox is closer to the truth in stating that the postscript does not contradict the rest of the book, but it rather "takes a different tack and adds a new dimension (Fox, A Time to Tear Down, 361)." I would suggest however that this "new dimension" was implicitly present all along, even if it did not come to the point of explicit imperative until the postscript. Perhaps Lee touches upon this when she writes, "While the emphasis on the divine commandments in the postscript may suggest a different orientation, the final command to fear God cannot be read in isolation from the rest of Qohelet's teachings on the theme throughout the book (Lee, Vitality, 113)."
} 
command to fear God in isolation from Qohelet's teachings on the theme as they are found throughout the entirety of the book. ${ }^{54}$

\section{The Fear of God and the Appointed Time of Judgment}

Three times throughout the book of Qohelet explicit reference is made to the impending judgment of God $(3: 17 ; 11: 9 ; 12: 14)$. In each of the three explicit points where divine judgment is referenced, allusion to the fear of God is contextually proximate $(3: 14 / 3: 17$; $12: 1 / 11: 9)$, and in the postscript it is syntactically linked to the "fear God" imperative through the causal conjunction "כ.." Nevertheless, alongside the "fear God" injunctions, many view these references to impending judgment as the glosses of pious redactors or they dismiss them as nothing more than the insertion of wishful thinking upon the text. ${ }^{56}$

If not attributing these references to the work of a glossator or "wishful thinking," commentators often view these references to judgment in a temporal sense, functioning as a tensive balance to the angst seen in the observations of injustice commonly reflected upon within the text (8:12-14 being an example where this probably is the case).

Representative of such an approach, Seow writes concerning 3:17 and 11:9, "He [Qohelet] does not speak of God's judgment in the future, as in a judgment day, only of a

\footnotetext{
${ }^{54}$ Lee, Vitality, 113.

${ }^{55}$ Commenting on the causal function of the conjunction $\gg$, Arnold and Choi write, "This conjunction forms a causal link between two clauses, introducing the reason an action or situation takes place, or providing the motivation for why something should be done ..." I believe that in this particular context impending judgment provides a strong motivation for the fear of God and obedience to his commandments. See Bill T. Arnold and John H. Choi, A Guide to Biblical Hebrew Syntax (New York: Cambridge, 2003), 149.

${ }^{56}$ Crenshaw remarks concerning 3:17, "This verse, then, may be a later gloss (Crenshaw, Ecclesiastes, 102)." On 11:9 and 12:14, Crenshaw similarly comments, "Using the same expression for divine judgment which appeared in 11:9 . . is again, totally alien to Qohelet's thinking (Crenshaw, Ecclesiastes, 192)."Anderson, as he does with the "enjoy life" references, attributes any eschatological wish for future judgment to nothing more than "wishful thinking." See Anderson, Pessimistic Theology, 108-09.
} 
deity who reserves the right to judge at any time and in any way." ${ }^{957}$ Similarly, Fox comments that the "there" at the end of 3:17 is "hardly an allusion, facetious or otherwise, to an afterlife." ${ }^{" 58}$ Such an approach is not based however in the explicit qualification of temporal parameters found in the description of judgment offered up by Qohelet; rather, it is based primarily in the view that Qohelet leaves no room for an afterlife in his theology of death. ${ }^{59}$ Nevertheless, such an assessment of Qohelet's theology of death is based upon the same conjecture as an assessment denying the possibility of personal eschatological judgment would be; the two cater to one another to support a kind of circularity in reasoning. Thus, while admittedly based in part upon the same conjecture, it is possible that Qohelet does hint at the possibility of eschatological judgment; indeed, some commentators have begun to push open the envelope, suggesting that Qohelet may in fact be hinting at the possibility of judgment that occurs in the realm beyond that of present human experience.

As one reads through the book of Qohelet, it is clear that Qohelet is not satisfied with the state of retribution in the present, yet he holds stubbornly to a faith that retribution and judgment will take place at some undisclosed time. Although Qohelet is admittedly unsure of when and where judgment will take place, and while certain

\footnotetext{
${ }^{57}$ It is interesting that on the same page Seow concedes that "the possibility of an eschatological judgment [is not] explicitly rejected." Also, in reference to $12: 14$, Seow suggests that "[I]t is probable that an eschatological judgment is meant in 12:14, for the text suggests that everything hidden will be revealed, whether good or bad," thus demonstrating the conjecture involved in determining such things from such ambiguous texts. See Seow, Ecclesiastes, 395.

${ }^{58}$ Fox, A Time to Tear Down, 215.

${ }^{59}$ Such a commitment to an annihilationist view of Qohelet's theology of death and the afterlife is apparent in Longman's comments on 3:17: "Qohelet implies that the time of fair judgment and proper retribution is not in the present. Yet in the following verses Qohelet also does not express a concept of eternal life and a judgment day." With this commitment in mind, Longman is forced to understand Qohelet against the implication suggested in verse 17. See Longman, Ecclesiastes, 127.
} 
contexts suggest that judgment will yet occur in the earthly realm $(8: 13),{ }^{60}$ there is no reason to dismiss the possibility that Qohelet may be leaving open the option of personal, eschatological judgment. ${ }^{61}$ The ambiguity in Qohelet's reflections on the "when and where" of judgment leaves open a number of options to the nature of retribution and justice, however speculative these may be from the "under the sun" perspective. Thus, Farmer is correct in stating that "Qohelet does not deny the possibility that God's judgment might take place somewhere outside of human experience." ${ }^{962}$

It seems that Qohelet is in quite the quandary as he reflects on his observations of life "under the sun." On the one hand, he sees a lack of justice and divine intervention into the world of the present $(8: 14)$, and yet on the other hand he knows that it will go better for God-fearing men than it will for the wicked (8:12-13). At the same time, from the "under the sun" perspective, he can only see the result of the curse in death-"from dust you are and to dust you will return (Gen 3:19b)." Thus, his view of the afterlife is limited by observation and experience, and anything that this wise sage may suggest is speculative at best. Nevertheless, in these three "judgment texts," however vague they may be, he essentially pushes open the envelope, hinting at the possibility of personal, eschatological judgment. Farmer articulates this logic as follows: "Once convinced that the traditional doctrine of retribution fails to reflect human experience, one either has to give up on the idea of justice or one has to push its execution into some realm beyond the

${ }^{60}$ Contra Murphy, who writes, "It is clear that Qoheleth denies that there is any intelligible retribution or justice in this life." What is unclear, however, is when this judgment of which Qohelet speaks will occur, in that Murphy states later that "[I]t is abundantly clear that Qoheleth does not hold out any hope for life after death." See Murphy, Ecclesiastes, lxvi, lxvii.

${ }^{61}$ Unless one is committed to the view of Murphy (and others) that, "Qohelet does not hold out any hope for life after death." See Murphy, Ecclesiastes, lxvii.

${ }^{62}$ Farmer, Who Knows What is Good?, 205. 
evidence of human experience." In my view, Qohelet does not ultimately give up on the idea of justice-the inclusion of the three "judgment texts," especially that of $12: 14$, if authentic, makes it untenable that Qohelet has given up on justice. Therefore, it seems best to understand these texts as suggestive of some form, however veiled in the details, of judgment executed beyond the grave.

Such a view, while in the minority, is not altogether absent from Qohelet scholarship. Zuck is quite "matter of fact" in viewing these references as pertaining to personal, eschatological judgment, stating that "after man dies, God will punish his sin." ${ }^{63}$ Garrett takes a more analytical approach, outlining his exegetical rationale for viewing the rather ambiguous reference to e ("there," lit., "a time for everything and every deed is there") at the close of $3: 17$ as a reference to personal, eschatological judgment. He writes:

This usage is eschatological. The word "there" is also used in Ps 14, another passage that deals with God's eschatological judgment on those who plunder his people. Psalm 14:5a reads, "There evildoers are overwhelmed with dread, for God is present in the company of the righteous." In context the line must refer to the day of judgment and vindication of Yahweh's people. "There" is either shorthand for the time and place of eschatological judgment or refers to Sheol (Hebrew; "grave"), in which case the ideas of the grave and the judgment have been merged. ${ }^{64}$

Although Garrett's assessment is far from universally accepted, ${ }^{65}$ his rationale is nevertheless compelling. ${ }^{66}$ Perhaps more compelling, however, are the arguments for eschatological judgment derived from 11:9 and 12:14.

\footnotetext{
${ }^{6 \hat{3}}$ Zuck, "God and Man in Ecclesiastes," in Reflecting with Solomon, 220.

${ }^{64}$ Garrett, Proverbs/Ecclesiastes/Song of Songs, 302-03.

${ }^{65}$ Garrett accurately criticizes Fox's analysis (see page 220 in this dissertation) as "superficial," contending that the "Teacher is caught in a tension between earthly realities (unpunished injustice and the apparent finality of death) and faith in the goodness of God. (The biblical conception of God's 7on ['faithfulness,' 'grace'] does not need to be expressly stated; it is a given.) His faith does not 'solve' the
} 
The strongest argument for post-mortem judgment in Qohelet is clearly derived from a reading of the postscript coupled with a view towards unified authorship between the postscript and the main text (that contained within the 1:2-12:8 inclusio). Even those who understand $3: 17$ and $11: 9$ as referencing a judgment other than eschatological judgment would concede that $12: 14$ is suggestive of an eschatological judgment. For instance, Seow comments on 3:17, "He [Qohelet] does not speak of God's judgment in the future, as in a judgment day, only of a deity who reserves the right to judge at any time and in any way." ${ }^{67}$ Likewise, in regards to $11: 9$, Seow takes an approach that defines judgment as accountability to the divine imperative to enjoy life, a contextually based approach that excludes the notion of eschatological judgment over sin and unrighteousness. ${ }^{68}$ However, on $12: 14$, he writes that the "content is quite different" and suggests that " $[\mathrm{I}] \mathrm{t}$ is probable that an eschatological judgment is meant in $12: 14$, for the text suggests that everything hidden will be revealed, whether good or bad. ${ }^{969}$ Lee too follows in suit, stating that "... it may not be amiss to note the possible hint of eschatological judgment in the claim that 'everything hidden' will be revealed (12:14b)." Even Longman, who is quick to distinguish between the main text "foil" and

problem in such a way that he can close the book on it. His integrity is such that he neither ignores injustice nor abandons faith." See Fox, Qohelet, 197-98, and Garrett, Proverbs/Ecclesiastes/Song of Songs, 302.

${ }^{66}$ While compelling, Garrett's argument is not without flaws. Exegetically, it is difficult to support from context the hope of eschatological judgment based solely on the word שם in verse 17. Twice (שמה with the directional $\pi$ ) is found in verse 16 , and in both cases, the place of judgment is clearly not eschatological.

${ }^{67}$ Seow, Ecclesiastes, 394.

${ }^{68}$ Ibid, 395. A similar approach to 11:9 is taken by Lee, who writes that "Qohelet urges the youth to enjoy life because God will hold humanity accountable for it (Lee, Vitality, 116)."

${ }^{69}$ Seow, Ecclesiastes, 395.

${ }^{70}$ Lee, Vitality, 116. 
the corrective represented by the frame-narrator in the postscript, concedes that $12: 14$ is speaking of an eschatological judgment: "The frame-narrator anticipates a judgment that will take place in the future rather than in the present, and one that includes hidden, or 'secret' acts. Thus, it is likely that he had an eschatological judgment in mind."71

If the postscript was authored by someone other than the author of the main text, or if it is representative of views unlike that of the main text, then such distinctions between the "judgment texts" would be tenable. However, aside from the broad based introductory evidence that supports a unified text, one also finds textual and thematic evidence linking 11:9 with 12:14. Lee comments on the "remarkable similarity in phraseology" between 11:9 and 12:14, stating that "the language in the postscript is so reminiscent of Qohelet's imperative of enjoyment in 11:9, it can hardly be incidental., ${ }^{, 72}$ Both texts call for judgment upon "every work" (מעשה, 12:14) or "all of these" (11:9), inclusive terms representative of human activities suspect to both sin and judgment (implied in 11:9, explicit in 12:14). In both texts God is called upon as judge, and in both texts the judgment is sweeping and comprehensive (implied in 12:14 through the reference to "every hidden thing, whether good or evil" [כל-נעלם אם-טוב ואם-רע], and implied in 11:9 through the reference to "all these" [כל-אלה], looking back on the imperative to rejoice [nive] and to follow the ways of one's heart and eyes). Although some may dismiss this similarity as nothing more than common glossing or the work of

\footnotetext{
${ }^{71}$ Longman, Ecclesiastes, 283.
}

${ }^{72}$ Lee, Vitality, 115-16. Lee continues by stating, "So, even while the postscript 'thematizes' along the lines of legal piety and divine judgment, it does so with language that recall's Qohelet's own teachings on peity with its emphasis on joy." I would argue that the thematic correspondence is even greater than that suggested by Lee (I understand that legal piety is not an altogether new concept introduced in the postscript but foreign to the main text), and that in this sense the thematic argument is actually stronger than the textual/syntactical, as suggested by Lee. See Lee, Vitality, 116. 
the epilogist using phraseology from the main text, ${ }^{73}$ there is no reason to dismiss a priori the notion that this similar phraseology might be evidence of a unified authorship, or at the very least, a thematic unity that runs throughout the entire book. ${ }^{74}$

\section{The Enjoyment of Life and the Fear of God}

No discussion of the "fear of God" motif in Qohelet is complete without drawing attention to the essence of the relationship between the fear of God and the enjoyment of life in Qohelet's wisdom. Both motifs are presented as conclusions to the matters upon which Qohelet reflects. The "enjoy life" motif is stated as such through the repetition seen in the thematic refrain and the escalation of that refrain from consideration $(2: 24-25$; $3: 12-13,22 ; 5: 18-20)$ to commendation $(8: 15)$, and finally to imperative command $(9: 7$ $10 ; 11: 9)$. Likewise, the "fear God" motif is stated as a conclusion in Qohelet's rhetoric as he expresses the necessity of fear through the knowledge of wisdom and faith $(3: 14$; 8:12), through imperative advice steeped in wisdom (12:1), and most importantly, in the explicitly stated conclusion to the reflections at hand (12:13-14). However, in viewing each motif as a conclusion, one must ask what relationship these two have to one another? Are they contradictory conclusions, are they designed to build and depend upon

\footnotetext{
${ }^{73}$ Murphy states that the epilogist uses the same phraseology as did Qohelet in 11:9, but contends that by "judgment" he (the epilogist) meant something different, sharing the "views of Sirach and another generation," thus implying that the epilogist brings a more defined understanding of eschatological judgment representative of the late inter-testamental period. See Murphy, Ecclesiastes, 126.

${ }^{74}$ Although he does not comment on specific, text based linkage between 11:9 and 12:14, Garrett, who affirms both a unified text and personal, eschatological judgment for all of the "judgment texts" in Qohelet, does in fact make note of the thematic unity that ties the main text to the postscript. Commenting that to treat the conclusion as a pious gloss or the like would be to "decapitate the entire work," Garrett recites the thematic unity that ties the conclusion to the rest of the book, stating: "Everything Ecclesiastes has affirmed up until this point-the sovereign freedom of God, the limits of human wisdom, thoughts on the use and abuse of power, and the brevity and absolute contingency of human life-all lead to the command to fear God. To excise the conclusion is to throw away that which binds together all the separate strands of the Teacher's thought. It arises from the failure to think like the Teacher, so to speak." See Garrett, Proverbs/Ecclesiastes/Song of Songs, 345.
} 
one another, are they actually near synonyms in Qohelet's theology, or are they meant to be taken as pragmatic wisdom set in balance to one another?

Although Qohelet is no stranger to extrapolating the enigmatic and absurd from his observations of life lived in a הבל world, his focus does not seem to be set on drawing such a conclusion between the enjoyment of life and the fear of God motifs. While there may be a tinge of irony in balancing and relating these two motifs as conclusions, they are not inherently opposed to one another, and in no portion of Qohelet is there any suggestion that they are incompatible. Such a notion of the incompatibility between the fear of God and the enjoyment of life is drawn from modern misconceptions of what the fear of God and the enjoyment of life might entail. If Qohelet had presented living in the fear of God as a life lived in sheer terror of impending doom, then there would be difficultly in balancing these conclusions. Or likewise, if he had portrayed the enjoyment of life as unbridled hedonism, and the fear of God as ascetic pietism, then the incompatibility would be obvious. However, as previously argued, the evidence supports viewing the enjoyment of life as a reception of the simple pleasures in life, given as a gift from God. Furthermore, the gift of enjoyment is viewed as the impetus for living life to its fullest potential, not in unbridled hedonism or anxious striving, but in the satisfaction gleaned from one's labor and reward. In the same sense, the fear of God has been presented in this chapter not as fear and trembling before a malevolent deity, or as ascetic pietism devoid of joy, but as the reverence due to an omnipotent and omniscient Creator to whom man is accountable. Therefore, the relationship between these two motifs is one of compatibility, not incompatibility. 
A popular approach that seeks to base the enjoyment of life in the fear of God is that of Walter Kaiser, who writes:

The purpose of life cannot be found in any one of the good things found in the world. All the things that we call the "goods" of life-health, riches, possessions, position, sensual pleasures, honors, and prestige-slip through man's hands unless they are received as a gift from God and until God gives man the ability to enjoy them and obtain satisfaction from them. God gives that ability to those who begin by "fearing," that is, believing Him. ${ }^{75}$

Thus, Kaiser seems to suggest that true joy in one's life can only be realized when reverence before the Creator has first been settled in one's actions and attitude. However, although this notion is palatable to a Christian worldview, it is based more in the perceived need to fit Qohelet's conclusions into modern Christian conceptions of worldliness and godly behavior than in what the text actually says regarding the fear of God and the enjoyment of life. Such an approach is similar to the popular notion that Qohelet is simply teaching that life lived apart from God has no meaning, a notion, that while arguably true, is demonstrably foreign to Qohelet's wisdom and rhetoric. As argued earlier, to do such is to strike a breach in theological context, reading modern Christian thought back into the mind of Qohelet. Whatever the relationship between the fear of God and the enjoyment of life, our assessment of Qohelet must stay within the confines of genre and theological context.

Yet another approach to this relationship is that of Eunny Lee, viewing enjoyment as a "vital aspect of Qohelet's vision of piety," wherein enjoyment becomes a "genuine expression of the fear of God." ${ }^{, 76}$ Lee's thesis, while encompassing much more than just this one point, nevertheless affirms the idea that Qohelet's theology of enjoyment does

\footnotetext{
${ }^{75}$ Kaiser, Ecclesiastes, 59.

${ }^{76}$ Lee, Vitality, 85, 122.
} 
have an ethical dimension wherein to enjoy life is to walk in obedience to God; to appropriate the fear of God is to enjoy life, and vice versa. Simply put, for Lee, "enjoyment is 'doing good' (3:12)." Commenting on Qoh 12:1, Lee speaks of the juxtaposition between the responsibility to enjoy life and the accountability over its fulfillment: "To remember one's 'Creator' is to do the will of God and enjoy life nowbefore it is too late, and with the knowledge that there will one day be a final reckoning." ${ }^{78}$ While Lee's work in demonstrating the compatibility between the enjoyment of life and the fear of God has been an immeasurable contribution to Qohelet studies (and to my own thinking), she is incorrect in her view that the two overlap in essence and fulfillment.

Rather than seeing enjoyment as a "vital aspect" of the fear of God, and vice versa, I propose yet another approach, one where the two motifs are meant to correspond in balance to one another. The enjoyment of life is not an expression of the fear of God, nor is the enjoyment of life a mandated "commandment" to which man is accountable. ${ }^{79}$ Rather, the enjoyment of life and the fear of God function together as separate yet complimentary expressions of wise living, and taken as wisdom imperatives, they are meant to balance one another as conclusions in Qohelet's wisdom rhetoric.

${ }^{77}$ Ibid, 82 (italics original).

${ }^{78}$ Ibid, 80. Furthermore, Lee purports the idea that mankind will be held accountable for enjoyment, understanding 11:9b as a direct reference to enjoyment: "know that for all these things, God will bring you into judgment (Lee, Vitality, 76)."

${ }^{79}$ Affirming the enjoyment of life as a divine commandment, Lee writes, "Rather, by appealing to God's judgment, the sage lends his counsel of joy all the weight of a divine commandment. He insists more strongly than ever before that enjoyment is the will of God, for which human beings will be held answerable." While I agree that enjoyment is the will of God so far as it is a wise approach to life (to not enjoy life is a foolish expenditure of the potential that God provides), I do not agree with Lee that it entails a matter of obedience or disobedience to the righteous will of God. See Lee, Vitality, 77. 
Nowhere is the correspondence between the enjoyment of life and the fear of God set in as tight a proximity as in Qoh 11:9, "Be glad (שמח) young man in your youth, and let your heart give you joy in the days of your youth. Walk (והלד) in the ways of your

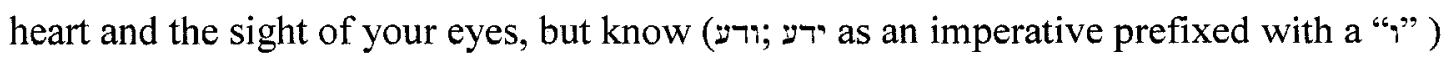
that for all of these things God will bring you to judgment." Understanding the waw in Qoh 11:9 as an adversative $w a w$ rather than as a conjunctive $w a w$, the effect of the imperative is, "enjoy, but know that God will judge you for your deeds," rather than "enjoy, and know that God will judge you for your deeds." Although the prior verb ולדף is an imperative with a conjunctive waw, there is no evidence aside from this verse that man will be judged over his obedience to the enjoy life imperative, nor does the judgment explicitly stated in Qoh 12:13-14 in any way suggest that man will be judged regarding the enjoy life imperative (but to the contrary, obedience to God's commandments). Thus, the fear of God is commanded (through the implication stemming from impending judgment) as an adversative compliment to balance the enjoyment of life, not as a warning that one's obedience or disobedience to the imperative will be judged. In this sense, the fear of God dictates that the wise man establish boundaries in his experience of joy, knowing that the line of distinction between the legitimate enjoyment of God's gifts and the ill-fated enjoyment of $\sin$ is an easy one to cross.

As an expression of wisdom, it is not surprising that Qohelet addresses his strongest appeal for balance to the young (11:9-12:1). As reflected in the book of Proverbs, Hebrew wisdom finds its traditional audience among the young, but for Qohelet, the appeal is as pragmatic as it is based on tradition. Likewise, the advice given

\footnotetext{
${ }^{80}$ The choice of an adversative waw rather than a conjunctive waw is a matter of broad contextual understanding rather than grammatical form. See Arnold and Choi, Biblical Hebrew Syntax, 146.
} 
to the young man is logical and sensible in light of all that Qohelet has observed. Rachel Z. Dulin, in an excellent article highlighting Qohelet's "age-centered teachings," brings this pragmatism and balance to light:

If one is convinced that the good life is a gift from God to enjoy and fulfill, then one must live every moment to the fullest (11:10). At the same time, if one agrees that there is accountability for all actions before God, and that God's actions are not predictable $(4: 1 ; 5: 1 ; 8: 14)$, one has no choice but to fear God and act responsibly. Therefore, the advice to the young is to live well by balancing enjoyment with accountability. ${ }^{81}$

In light of the inevitability of death and the fleeting nature of life, it is only proper that Qohelet's wisdom of present possibility and potential be addressed to the young, to those who are best able to capitalize on the vitality of the life at their disposal. However, it is also crucial that Qohelet's wisdom of caution, sobriety, and balance be addressed to the young, for it is in the early years of one's life that actions are committed for which one will later be held accountable. ${ }^{82}$ Essentially, from an "under the sun" perspective, there are no "do overs" in this fleeting life. Therefore, it is crucial that the young person remember God before they must give account (12:1), even as it is imperative that the young person enjoy life while the opportunity is available to them (9:7-10).

\footnotetext{
${ }^{81}$ Rachel Z. Dulin, "How Sweet is the Light: Qoheleth's Age Centered Teachings," Interpretation $55(2001), 266$.

${ }^{82}$ Sobriety too is a measured balance to the enjoyment of life. Castellino suggests as much when he writes in the conclusion to his study on Qohelet and the essence of his wisdom, "The only reasonable course will be to view life and man's lot in the world with a sober mind and realistic consideration ..." At this point Castellino also reminds his reader of Qohelet's concluding advice, " . . be thankful to God for whatever satisfaction he gives you, valuing and measuring everything as a gift from him and enjoying it, never forgetting that you shall have to render strict account to God himself." See George R. Castellino, "Qohelet and His Wisdom," CBQ 30 (1968), 28.
} 


\section{CHAPTER 9}

\section{IN CONCLUSION: THE INTER-DEPENDENCY OF THE PROMINENT MOTIFS WITHIN THE BOOK OF QOHELET}

In the previous eight chapters, I have presented an argument for the essential unity of the book of Qohelet. This has been done both implicitly and explicitly, in the introduction as well as throughout each chapter. While discussions within the realm of higher criticism are both intriguing and valuable, and while a strong argument can be made for the integrity of the book, it is the issue of message that has been of primary concern throughout these eight chapters. As each motif has been surveyed pertaining to content and character, the inter-dependency between ideas argues not for multiple layers of authorship and development, but rather, for a unified message wherein distinct thematic elements coalesce into a complex yet unified message. Any proper and balanced approach taken to the book of Qohelet must therefore consider each prominent motif as equally valid and intentionally critical to the whole message of the book. To elevate any given motif to the exclusion or suppression of others is to warp the theological message of the book. Furthermore, through the misinterpretation of the theological message of Qohelet one also loses the practical message intended by the text-the establishment of a balanced, broad based paradigm for living wisely in a הבל world. 


\section{The Inter-dependency of הבל to Related Motifs}

The diagnosis of the problem of הבל is well established throughout the whole book of Qohelet, and touches upon each of the motifs surveyed throughout this dissertation. Understood as a multivalent (and in a sense, omnivalent) symbol, the concept of hevelness describes the whole of fallen creation. So pervasive is this concept of הבל that it can be used to describe nearly every aspect of the reality in which man exists. Given the four prominent connotative senses in which Qohelet attributes the הבל symbol to the world of fallen reality, there is virtually nothing in this world that cannot in some sense be described as הבל. The concept of hevelness is not necessarily pessimistic, cynical, or overtly negative; it is simply a descriptive concept reflective of the fallen world in which life takes place. Indeed, even the good things in life can in some sense be described as הבל הבל The concept therefore not only multivalent, but it also can carry negative, neutral, and even positive associations.

$$
\text { יתרון, and the Pursuit of Wisdom }
$$

If one is to understand the message of Qohelet, one must first understand the dilemma with which Qohelet was faced along with the solution to which Qohelet was searching. As proclaimed by way of the superlative inclusio $(1: 2 ; 12: 8)$ and confirmed in a multitude of observations and reflections throughout the body of the text, the dilemma facing Qohelet, and indeed, all of creation, is the pervasive hevelness that encompasses all that is and is done in the fallen cosmos. Thus, as one reads the programmatic question in Qoh

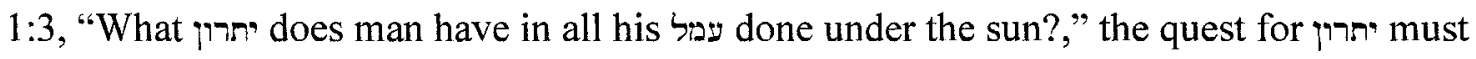
certainly be understood in light of the dilemma of הבל. And so, guided by wisdom yet 
limited through an "under the sun" perspective, Qohelet sets off on a quest to find תרון, a solution to the dilemma of לas.

יתרון, however, is as elusive in Qohelet's quest as הבל is pervasive, and thus Qohelet never does find that for which he originally sought. This shortcoming came not as a result of an inept sage; indeed, Qohelet himself was not lacking in wisdom. Rather, wisdom itself was soon discovered to be inadequate for the job, for it, as with all other human endeavors, is subject to the same judgment of הבל observed throughout the whole of creation.

Realizing that the imposition of limitation is maintained by divine intention, and that God's desire is that man fear him in sober recognition of the full weight of living in a יתרון , and towards a wisdom based, divinely sanctioned paradigm for living wisely in a הבל reality. And thus Qohelet pursues wisdom, fully aware of its own limitations, yet knowing that through wisdom a man is best equipped to live life in light of the hevelness of it all.

\section{הבל and its Relationship to the Inevitability of Death}

Although the concept of transcends far beyond the mere notion of transience, there nevertheless is a strong tie conceptually and contextually between the hevelness of life and the inevitability of death in Qohelet's theological rhetoric. In the many contexts wherein the primary connotation of הבל touches most strongly upon life's transient nature, the somber reflections regarding the inevitability of death are always close at hand. In the same sense, in relating to another of "hevel' $s$ " connotative families of meaning, at least some degree of life's "vanity" is dependent upon the notion of the inevitability of death. Indeed, the climatic allegory on the inevitability of death (12:1-7) 
strikes its final chord just prior to the final proclamation of the superlative (12:8), reinforcing the somber recognition of life's only guarantee in a הבל world. ${ }^{1}$

As the primary result of the fall and the central descriptive concept in the notion of mortality, it is hardly surprising that death would be central in Qohelet's musings on life. This preoccupation with death, however, should not be surmised as indicative of a pessimistic approach to life, but rather, it demonstrates a very realistic approach to temporal existence and the demands of living in recognition of mortality, or better stated, in recognition of the hevelness of life.

הבל and Its Relationship to the Determinacy of God and the Limitation of Man Throughout the book of Qohelet, various observations and reflections encompass the whole of reality in such a way that all of life can appropriately be described as הבל. However, in contrast to the various paradigmatic experiences and elemental entities that make up the cosmos, the one thing not described by Qohelet as being הבל is God. The concept of Divine Otherness is framed in Qohelet in such a fashion that the reader is prompted to recognize that there is indeed one entity not subject to the hevelness that is so pervasive in man's experience, and that entity is God (3:14a). Such recognition, implied throughout the text but explicitly referenced in $3: 14 \mathrm{c}$, should drive mankind to "fear God" as the Creator who is anything but הבל. Yet ironically, when perceived by mankind from the under the sun perspective (and remember that this perspective is neutral, simply the place in reality where we all live), the activities of the Creator, and

\footnotetext{
${ }^{1}$ It is somewhat ironic (or (הבל) that the only guarantee in a world without guarantees (remember, this lack of guarantee is in Qohelet's mind, הבל ) is the inevitability of death (a very hation).
} 
especially his immanent dealings with the affairs of mankind, are best described in their mystery as nothing less than הבל.

Central to the הבל symbol is the notion of the "absurd," described by Fox as that which comes as an "affront to human reason." Although absurdity is only one aspect of enigma within the symbol, it is perhaps the most emotionally loaded, and captures well the inner-dependant motifs of sovereign determinacy and the imposition of limitation upon mankind. Although mankind is already הבל by way of his own mortality, this concept is broadened and further heightened through the inter-dependency between the הבל motif and Qohelet's own brand of theological anthropology. Indeed, the sovereign determinacy of God and the imposition of limitation placed upon humanity by his Creator, when viewed as motif, are commensurate with the notion of divine enigma and the frustration inherent with the realization of the absurd. Thus, the enigmatic family of meaning and the frustration family of meaning within the הבל symbol come together to describe well what Qohelet observes in reference to his theological anthropology, and vice versa. The fact that man cannot control his own future; indeed, the fact that mankind cannot have any insight into the "why" of divine determinacy causes Qohelet no shortage of vexation. Qohelet is not simply burdened by divine mystery, but the inscrutable activity of God, most importantly viewed in the deployment of justice, is too often an affront to the senses of right and wrong, and for this Qohelet has no answer. Such הבל anorance of divine rationale leads to frustration, all of which is a part of living in world. While the full explication of Qohelet's anthropological theology demonstrates divine purpose in the imposition of limitation (3:14c), there nevertheless is every reason

\footnotetext{
${ }^{2}$ Fox, $A$ Time to Tear Down, 3.
} 
to proclaim "as "הבל" the mysterious Otherness of the divine and the great gulf set between man and God, especially when viewed from the "under the sun" perspective.

\section{The Inter-dependency of Wisdom to Related Motifs}

The book of Qohelet encapsulates wisdom in a variety of forms and function. The text itself contains a wide spectrum of wisdom genre, and as a whole, the book is rightly considered wisdom literature. However, wisdom also takes on the dual role of perspective and motif throughout the book. As to perspective, Qohelet clearly pursued his quest while looking through the "lens of wisdom" $(1: 13 ; 2: 3,9)$, with the text itself affirming the veracity of Qohelet's sapiential wisdom (12:9-11). As to motif, Qohelet evaluated the merits of wisdom as a means to solving the dilemma of and found that wisdom was wanting, for it too was הבל Nevertheless, Qohelet still found wisdom to be of great value in relation to the many aspects of the הבל indictment, even if it did not ultimately result in יתרון. In a sense one might say that wisdom did find a solution to the dilemma of , even if this solution fell short of תרון".

Realism and the Capacity to Affect Change: Probabilistic Wisdom and Its Relationship to Determinacy and Limitation

Qohelet takes a realistic look at wisdom, citing its limitations and yet embracing it for its capacity to provide advantage in life, even if this advantage does not reach the high aspirations of יתרון. Knowing that man has no certain control of the future, even his own future, Qohelet espouses a theology of present opportunity and future possibility, all based in the wisdom of probability. For Qohelet, the greatest potential for success in an uncertain world lies in wisdom. Even though wisdom cannot guarantee anything 
regarding a man's future, it nevertheless provides greater opportunity for the present and the capacity to enhance the potential for success in the future.

In Qohelet's theology of God and man, God always has the upper hand; God always has the final say ("no one can straighten what God has made crooked," Qoh 7:13). Nevertheless, the very essence of wisdom is such that man has volitional capacity to affect change in the present, even if such change is based in probabilities without guarantee. In full view of the הבל world in which man lives, and with complete knowledge that God's inscrutable sovereign will must take precedence over man's capacity to affect change, Qohelet nevertheless commends wisdom as the means to making the most of life in a הבל world.

The wisdom of possibility and probability is best viewed through the many proverbs contained within the book, especially prominent in chapters 7, 10, and 11:1-6. While these proverbs contain elements of conventional wisdom similar to that found in the book of Proverbs, there is a certain air of inherent risk in the wisdom of Qohelet, risk based in a theology of present opportunity and responsibility, all the while cognizant of future possibility and, when wisdom is properly applied, probability. Such a paradigm for wisdom is ultimately rooted in Qohelet's observations regarding the reality of הבל and double agency. The degree to which determinism limits the capacity for man to guarantee change is at once balanced by man's responsibility to seize present opportunity for the sake of probable future reward. 
A New Paradigm for Living: How Wisdom Relates to the Enjoyment of Life and the Fear of God

The wisdom of Qohelet moves beyond the narrow, practical application of living wisely in the affairs of the daily grind; it ultimately establishes a broad, wisdom based philosophy for living in light of the hevelness of life. ${ }^{3}$ Qohelet's wisdom ultimately boils down to a two-fold wisdom based philosophy for living in a הבל world: First, in light of the observation that life is fleeting, death is inevitable, and the circumstances of one's future lie outside of the realm of man's control, the wise will enjoy life, recognizing that joy is ultimately an opportunity for present satisfaction given as a gift from God. Second, in light of the observation that life is fleeting, death is inevitable, and God's enigmatic ways on earth are sure to be followed by an equitable future judgment, the wise will fear God and keep his commandments. Therefore, the wise man or woman will enjoy life but not enjoy sin, living each day to its fullest, but also living in sobriety, knowing that for all our actions there is a coming judgment. This is the wisdom of Qohelet.

The dual conclusionary motifs on the enjoyment of life and the fear of God are not simply theological imperatives, although one could certainly argue that their propositional value transcends mere advice. While their authority is based in propositional revelation, they are equally valid as words of wisdom, based in the practical mind of the Hebrew sage. As words of advice, the message of joy and fear comes from the wisdom of one who has asked the question, "What is good for a man to do during his lifetime (Qoh 6:12)?" So as wisdom, the "enjoy life" motif and the "fear God" motif function to provide a wisdom based paradigm for living in the messy reality of a fallen world, and as such, bring God's people to the theological apex of canonical wisdom.

\footnotetext{
${ }^{3}$ The idea of "hevelness" of course includes the concepts of God's inscrutable will, the imposition of limitation upon man, and the ultimate "הבל," the inevitability of death.
} 


\section{The Inter-dependency of the Inevitability of Death to Related Motifs}

Whether it is implied within the sבל symbol or explicitly proclaimed through reflection and allegory, the recognition of death's inevitable reality is central in Qohelet's theology as well as his wisdom rhetoric. Theologically, the inevitability of death functions as a descriptive recognition of the inescapable result of the fall (Gen 3:19b), and as such is intricately tied to the הכל symbol. Furthermore, from the theological perspective, death comes as the ultimate display of God's inscrutable jurisdiction and the inability of man to know the culmination of his own mortality. Practically, the inevitability of death functions within Qohelet's wisdom rhetoric as a means to motivation: First, the motivation to seize the day (Qoh 9:10), and second, the motivation to remember God (Qoh 12:1). As such, death has an air of somber theological reflection within Qohelet, but from the perspective of Qohelet's wisdom, an acknowledgement of the inevitability of death is among the most beneficial things to which wisdom speaks.

The Ultimate Display of Divine Determinism: The Inevitability of Death, Divine Jurisdiction, and the Inability of Man to Know His Future

Qohelet's theology is such that it does embrace the double agency of sovereign determinism and human responsibility. However, pertaining to death, mankind's agency is limited only to probabilistic wisdom; one can live in such a manner that the quality of life is enhanced and the probability of a long life is heightened, but ultimately, the days of one's life and the timing of one's death is in the hand of God (Qoh 9:11-12). Thus, while Qohelet makes clear his theology of divine determinism through a variety of reflections and propositional statements, it is the sovereign jurisdiction over the timing of every mortal's death that comes as the most pervasive evidence of God's hand over humanity. 
Qohelet strikes a balance between wisdom and presumption in his approach to the theological inquiry regarding the timing of death, divine jurisdiction, and the influence man wields over the determination of such. Ultimately, he comes to see man's inability in securing the future as reflective of God's judgment over a fallen world, yet he nevertheless encourages righteous living under the assumption that moral decision making may indeed be influential in determining the day of one's death. Qohelet speaks out strongly against the assumption that God's mysterious activity translates into a transcendent lack of concern. Indeed, to live as if there were no God is to court disaster, and to live as if circumstances and judgment were unrelated is to play Russian roulette with an Almighty God. Qohelet would agree with the Psalmist, "The fool says in his heart, 'There is no God." ",4 And so wisdom is born from a knowledge of who God is and where man stands in relationship to him. For wisdom to have its fullest value, one must live in the knowledge of the inscrutable nature of divine jurisdiction and the inevitability of death. In this sense, wisdom is a shelter, preserving the life of its possessor (Qoh 7:12), yet ultimately, man has no guarantee over his future in view of the inscrutable activity of God (Qoh 7:13-14).

The Inevitability of Death as Motivation to Seize the Day Whether through the implicit message of the הבל indictment or the more explicit reflections on the somber reality of death, the thematic and textual inter-dependency between the inevitability of death and the enjoyment of life is as pervasive as any other relationship in the book of Qohelet. In particular, the two examples of the "enjoy life" refrain set in the imperative are contextually framed by reflections on the inevitability of

\footnotetext{
${ }^{4}$ Psalm 14:1, NIV.
} 
death $(9: 2-6,10$ framing $9: 7-9 ;$ and $11: 8 b, 10-12: 1-7$ framing $11: 8 a-9)$, thus implying that to some degree the future spectre of death functions as motivation for the present enjoyment of life. While there are certainly other reasons to enjoy life, not the least of which being the point that the opportunity for present enjoyment comes as a gift from God, there nevertheless is a sense in which wisdom demands that a man enjoy life while he has the opportunity to do so. Indeed, it would be the height of folly to put off present opportunity to a future day that is not guaranteed. It is in the present that God favors the work of one's hands, and it is in the present that through wisdom man may achieve some degree of success in life. In reference to death as the motivation to live life to its fullest capacity, Qoh 9:10 functions as the climatic height of probabilistic wisdom, an imperative calling for the wise man to seize the day as it is experienced in the present, the only period in time in which man has any sure opportunity: "Whatever you hand finds to do, do it with all your might, for in the grave, where you are going, there is neither working nor planning nor knowledge nor wisdom (Qoh 9:10, NIV)."

\section{The Inevitability of Death as Motivation to Fear God}

If the inevitability of death functions as a wise man's motivation to enjoy life as a present gift from God, how much more should the inevitability of death function as a potent motivator to fear God in the days of one's activity under the sun. Although Qohelet recognizes that justice is often subject to the veil of mystery in this present הבל world, he nevertheless holds onto a hint of faith based expectation that God does indeed act in the present, even if the rationale behind his judgments seem absurd in the context of a fallen world (8:12-14). This alone should act as a present motivator for the wise man to fear God. However, as argued in chapter eight, I would suggest that Qohelet too is in 
expectation of a future, personal, post-mortem judgment that rights the wrongs in this present, הבל world. Such judgment, while obscure in detail, is nevertheless comprehensive and sure (12:14). With mankind accountable for his actions in the present, the true height of folly would be for a man to live in the present apart from the expectation of future, divine judgment.

Just as Qoh 9:10 functions as the climatic imperative demonstrating the interdependency between the "enjoy life" refrains and the inevitability of death, so too Qoh $12: 1$ functions as the climatic imperative between the "fear God" motif and the inevitability of death ("Remember you Creator in the days of your youth, before the days of trouble come..."). Furthermore, in each case there is a sense of rationale behind the wisdom imperative-just as the wise man will seize the day because tomorrow is not guaranteed $(9: 10)$, so too the wise man will remember God in the present for tomorrow he may be giving an account before his Creator for "every deed, including every hidden thing, whether it is good or evil $(12: 1,14)$." For the wise man, to live in the expectation of death is to live in the fear of God. Not only is this theologically tenable, it is common sense. Given the fleeting nature of life and the inevitability of death, only the fool would live life as if youth were enduring and tomorrow was guaranteed-only a fool would live as though he would not soon answer for the deeds that he has done.

\section{The Inter-dependency of the Enjoyment of Life and the Fear of God to Related Motifs}

Throughout the development of the enjoy life refrains, as they escalate from consideration to commendation to commandment, each prominent motif in some manner influences Qohelet's theology of enjoyment. Stated seven times throughout the text and 
escalating to provide the sense of conclusion, ${ }^{5}$ there is little doubt that the enjoyment of life functions as a central point of theological and practical concern in Qohelet's message, and any approach to the book must not diminish its prominence. Supporting the rationale for its centrality is the observation that each of the other prominent motifs can be seen within the refrains or in contextual proximity to the refrains. For instance, the pervasive influence of the דבל motif touches upon the enjoyment of life in multiple ways, from the motivation inherent in the fleeting nature of youth $(9: 9 ; 11: 10)$ to the absurd (and perhaps frustrating) manner in which the opportunity for enjoyment is dispersed among men (6:2). Even satisfaction and joy in one's labor might be seen as a vain pursuit apart from the sovereign provision of joy as a divine gift $(2: 23,26)$, and thus to some degree the full range of the הבל symbol touches upon the "enjoy life" motif.

Even as the enjoyment of life is understood in relationship to other motifs, so too is the fear of God set in correspondence with related thematic elements. The fear of God is grounded in the observation that God, unlike fallen creation, is emphatically not הבל. So too is the fear of God established via the "under the sun" existence in which man lives and breathes. It is in the knowledge that "God is in heaven and you are on earth" that Qohelet admonishes the wise to proceed reverently before his Creator (5:2-7).

In like manner, the enjoyment of life is contextualized as it is experienced "under the sun" $(5: 18 ; 8: 15 ; 9: 9)$, and it is through this "present perspective" that the enjoyment of life is commended. Not only is enjoyment experienced in the present realm, but the rationale for such is set within the theological context of the under the sun perspective. Qohelet does not approach life from a vertical perspective, wherein his focus is upon a

\footnotetext{
${ }^{5}$ Although support for such numerical significance may be highly subjective, perhaps there is some significance to the observation that as a conclusion, the "enjoy life" refrain is repeated seven times throughout the book.
} 
future joy in heaven, wherein the joys of the present may be forsaken for a heavenly reward which cannot be lost, which can never be described as הבל. Therefore, given the context in which all men live, and given that enjoyment is expressly proclaimed to be a gift from God, it is incumbent upon the wise believer to enjoy life as a gift even in light of the New Testament perspective on this world and the heavenly realm. After all, life today is still lived in a הבל world, and the light of life is still given as a gift to be enjoyed during the days in which mortal man lives "under the sun."

The enjoyment of life too cannot be viewed apart from wisdom, for it is in the spirit of wisdom that Qohelet commends the enjoyment of life. The escalation from consideration to commendation to imperative does not stem from legal, revelatory commandment, nor is it based in the theology of the cult. So also, in Qohelet, the fear of God comes as the result of wisdom, not of legal dictate.

Experienced as a gift, the enjoyment of life finds its origin in the grace of God $(2: 24 ; 3: 13 ; 5: 19 ; 9: 9)$, but even as such, the inscrutable choice of divine favor is meted out on inequitable terms. Thus, even while God provides the opportunity for enjoyment, he does not necessarily do so equally, and the rationale behind such must remain a divine mystery (6:1-2). Nevertheless, human agency is involved in the appropriation of the opportunity that God does provide, and furthermore, may even provide impetus for greater joy and favor $(2: 26 ; 6: 1-2)$.

Beyond the observation that enjoyment comes as a gift from the Creator, one can also see the inter-dependency between the enjoyment of life and the divine mystery in the second "enjoy life" refrain (3:12-13). Here the enjoyment of life is framed by Qohelet's own acceptance of the imposition of limitation upon mankind $(3: 11)$ and the contrast 
purported by the "Otherness" of God (3:14). If there is any sense of concession in the "enjoy life" motif, it is found in view of the inscrutable mystery of God (3:12-13). God has given man the opportunity to enjoy life even while man cannot have full disclosure of the future or the divine will that controls its outcome. It is for man to find satisfaction in the toil of his labors; such contentment is indeed the gift of God. The imposition of limited knowledge upon mankind is not an oversight on the part of God. Rather, it is intentional and with divine purpose-the purpose being to generate the fear of God $(3: 14 c)$.

Although the enjoyment of life and the fear of God have similar inter-dependent relationships with the prominent motifs found in the book of Qohelet, the two conclusionary motifs are actually less contextually integrated than one might expect. Nevertheless, the relationship between the fear of God and the enjoyment of life is central to the wisdom of Qohelet, and the book cannot be correctly read without considering the one in light of the other. While the two motifs only cross paths in one particular context $(11: 9-12: 1)$, the establishment of a two-fold wisdom paradigm in conclusion to the matters at hand argue for an off-set balance between the two that transcends the narrow scope of exegetical inquiry. If the enjoyment of life can take on the role of conclusion, then too it must be established in corresponding relationship to the one motif that is explicitly stated to be the conclusion to the whole matter - the fear of God. How do these two correspond? They correspond by establishing a two-fold, balanced paradigm for living wisely in a הבל world. 


\section{How the Wise Should Live: The Balanced, Two-fold Wisdom Response to Living in a הבל World}

The goal of this dissertation has been to propose an approach to the book of Qohelet that demonstrates exegetical integrity and theological balance. Taking a thematic approach to the book, I have sought to integrate the prominent motifs observable within Qohelet as a means to discovering the message of the book as a whole. Instead of focusing on one motif as the "Leitmotif", and rather than elevating one set of motifs to a position of prominence all the while relegating others to obscurity, the approach presented and defended in the preceding pages has sought to view all of the prominent motifs with equal consideration in assessing an overall message to the book. Additionally, the proposed approach in this dissertation has considered each motif as an inter-dependent compliment to the others, framed within the context of Hebrew wisdom literature. The result has been an emphatically positive approach to the book that establishes a pragmatic and realistic wisdom based paradigm for living in a fallen world.

Qohelet's conclusions are two-fold and equally balanced. First, in light of the observation that life is fleeting, death is inevitable, and the circumstances of one's future lie outside of the realm of man's control, the wise will enjoy life under the sun as a gift from God, recognizing that joy is ultimately a responsibility and an opportunity set before him. Second, in light of the observation that life is fleeting, death is inevitable, and God's enigmatic ways on earth are sure to be followed by an equitable future judgment, the wise will fear God and keep his commandments, for he is accountable for every deed committed under the sun. Therefore, the wise man or woman will enjoy life but not enjoy sin, living each day to its fullest, but also living in sobriety, knowing that for all our actions there is a coming judgment. Furthermore, the wise man will not allow the 
absurdity of reality or the perception thereof to gain the upper hand of vexation and strife-he will come to know the limits of wisdom, the Otherness of God, and the limitations of mortality.

Although rich in theological insight, the wisdom rhetoric of Qohelet is ultimately geared towards the practical implementation of a new perspective for living, a balanced paradigm for living in a troubled and complex world. The application of the two-fold wisdom of Qohelet-enjoying life in the present as a gift from God all the while living in the fear of God and the expectation of future judgment-provides a beautiful and needed wisdom message for all of God's people, regardless of age, ${ }^{6}$ race, culture, or ecclesiastical persuasion. For many readers, the message of Qohelet is lost in the challenge of interpretation and the difficulty of describing theological and practical realities in a complex and unsystematic world. Furthermore, the literary distance involved between the text of Qohelet and the modern reader heightens the challenge for even the most astute. Nevertheless, the message of Qohelet is as timeless and as critical as any in canonical wisdom. I trust that this wisdom paradigm may be appropriated by all of God's people as they contextualize these broad based wisdom principles to their own particular experience of living in a tarld.

\footnotetext{
${ }^{6}$ I would however argue that this message is most pressing and relevant for adolescents and young adults. For rationale supporting the argument that Qohelet's message was primarily geared towards the young, see Dulin, "How Sweet is the Light," 260-70.
} 


\begin{abstract}
APPENDIX A
The following chart (next page) illustrates the number and the locations of segmented citations for each of the motifs surveyed throughout this dissertation. The entire text of Qohelet is represented by these citations, with the exception of Qoh 1:1, 12. Each citation was segmented as a unit of thought, and does not necessarily match lexical occurrences of key terms and phrases. In certain cases, the idea behind a motif was implied, but there were no explicit references to the motif in lexical form. This is illustrated by the designation of Qoh 1:3-11 as representing the הבל motif, even though the word הבל is not found within this text. In this case, it is the concept of הבל that is communicated by these verses, not the lexical term itself.
\end{abstract}




\begin{tabular}{|c|c|c|c|c|c|c|c|c|c|c|c|c|}
\hline$\frac{0}{\frac{1}{6}}$ & Ch. 1 & Ch. 2 & Ch. 3 & Ch. 4 & Ch. 5 & Ch. 6 & Ch. 7 & Ch. 8 & Ch. 9 & Ch. 10 & Ch. 11 & Ch. 12 \\
\hline 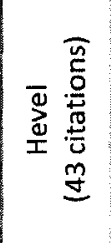 & $\begin{array}{l}\text { } 1: 2 \\
1: 3-11 \\
1: 14 b \\
1: 17 b \\
1: 18\end{array}$ & $\begin{array}{c}2: 12.2 \\
2: 3-11 \\
2: 15 \\
2: 17 \\
2: 19 \\
2: 21 \\
2: 22 \cdot 23 \\
2: 26\end{array}$ & $\begin{array}{l}3: 16 \\
3: 19\end{array}$ & $\begin{array}{c}4: 1-3 \\
4: 4 \\
4: 5-6 \\
4: 7-8 \\
4: 13: 16\end{array}$ & $\begin{array}{c}5: 7 \\
5: 8-10 \\
5: 13-14 \\
5: 15 \\
5: 16: 17 \\
5: 18\end{array}$ & $\begin{array}{l}6: 1-2 \\
6: 3-6 \\
6: 7-9 \\
6: 12 a\end{array}$ & $\begin{array}{r}7: 6 \\
7: 15 \\
7: 16 \\
7: 29\end{array}$ & $\begin{array}{r}8: 9 \\
10 \\
8: 11 \\
13 \\
8: 14\end{array}$ & $\begin{array}{r}9: 2-4 \\
9: 9 \\
9: 16\end{array}$ & $10: 6-7$ & $\begin{array}{l}11: 8 \mathrm{c} \\
11: 10 \mathrm{~b}\end{array}$ & $12: 8$ \\
\hline 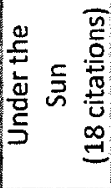 & $\begin{array}{l}1: 96 \\
1: 14\end{array}$ & $\begin{array}{l}2: 11 \\
2: 18 a \\
2: 20\end{array}$ & $3: 1$ & $\begin{array}{l}4: 3 \\
4: 7 \\
4: 15\end{array}$ & & $\begin{array}{r}6: 1 \\
6: 12 b\end{array}$ & & $8: 9$ & $\begin{array}{c}9: 3 \\
9: 6 \\
9: 9 \\
9: 11 \\
9: 13\end{array}$ & $10: 5$ & & \\
\hline 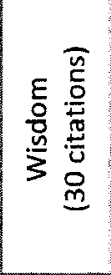 & $\begin{array}{l}1: 13 a \\
1: 16- \\
18\end{array}$ & $\begin{array}{c} \\
2: 3 a \\
2: 9 b \\
2: 12 \\
16\end{array}$ & & $\begin{array}{c}4: 5-6 \\
4: 9 \\
12 \\
4: 13-16\end{array}$ & $\begin{array}{c}5: 1-3 \\
5: 10 \\
12\end{array}$ & $\begin{array}{l}6: 8 \\
6: 9 \\
6: 11\end{array}$ & $\begin{array}{c}7: 1-10 \\
7: 11 \\
7: 16 \\
18 \\
7: 19 \\
22 \\
7: 23 \\
29\end{array}$ & $\begin{array}{r}8: 1 \\
8: 2.6 \\
8: 9 \\
8: 16 \\
17\end{array}$ & $\begin{array}{r}9: 13- \\
16 \\
9: 17 \\
18\end{array}$ & $\begin{array}{c}10: 14 \\
10: 8-11 \\
10: 8-11 \\
10: 12-148 \\
10: 15-20\end{array}$ & $11: 1-6$ & $\begin{array}{c}12: 9 \\
12\end{array}$ \\
\hline 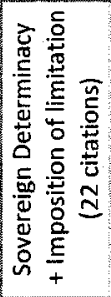 & $\begin{array}{r} \\
1: 136 \\
1: 15 \\
\end{array}$ & $2: 26$ & $\begin{array}{c}3: 1 \\
8 \\
3: 9 \\
11 \\
3: 14 \\
3: 15 \\
3: 18\end{array}$ & & $\begin{array}{c}5: 26 \\
5: 19 \\
20\end{array}$ & $\begin{array}{l}6: 1-2 \\
6: 10\end{array}$ & $\begin{array}{r}7,13 \cdot 44 \\
7,25,27,29\end{array}$ & $\begin{array}{r}8: 5 \\
6 \\
8: 7 \\
8: 8 a \\
8: 17\end{array}$ & \begin{tabular}{|c|} 
\\
$9: 1$ \\
$9: 11$ \\
12
\end{tabular} & $\begin{array}{l}10: 14 b \\
0\end{array}$ & 11:5-6 & \\
\hline 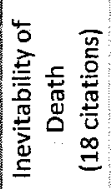 & $\begin{array}{l}1: 4 \\
1: 11\end{array}$ & $\begin{array}{l}2: 3 b \\
2: 14 b \\
2: 16 \\
2: 18 b\end{array}$ & $\begin{array}{r}3: 19 \\
21\end{array}$ & & $\begin{array}{c}5: 15 \\
16 \\
5: 18\end{array}$ & $\begin{array}{r}6: 6 \\
6: 12 b\end{array}$ & $7: 1$ & $8.8 \mathrm{~b}$ & $\begin{array}{l}9.26 \\
9.10 \\
9.12\end{array}$ & & $11: 8 b$ & $\begin{array}{r}12: 16 \\
7\end{array}$ \\
\hline 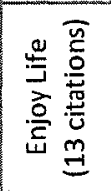 & & $\begin{array}{l}2,24 \\
25\end{array}$ & $\begin{array}{r}3: 12: 13 \\
3: 22\end{array}$ & $4: 8 \mathrm{C}$ & $\begin{array}{r}5: 18 \\
20\end{array}$ & $\begin{array}{l}6.1 \\
2 a\end{array}$ & $\begin{array}{l}7: 2-4 \\
7: 14 a\end{array}$ & $8: 15$ & $9: 7-9$ & & $\begin{array}{r} \\
11: 78 \mathrm{~s} \\
11: 9 \\
11: 10 \mathrm{a}\end{array}$ & \\
\hline 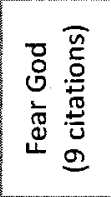 & & & $3: 17$ & & $\begin{array}{l} \\
5: 1-7\end{array}$ & & $7: 18$ & $\begin{array}{r}8: 8 c \\
8: 12 \\
13\end{array}$ & & & $1199 \mathrm{~b}$ & $\begin{array}{l} \\
12: 1 \mathrm{a} \\
12: 6 \mathrm{a} \\
12: 13-14\end{array}$ \\
\hline
\end{tabular}




\section{APPENDIX B}

The following chart illustrates how each verse in the book of Qohelet (with the exception

of Qoh $1: 1,12$ ) reflects either implicitly or explicitly one or more of the seven prominent motifs surveyed throughout this dissertation.

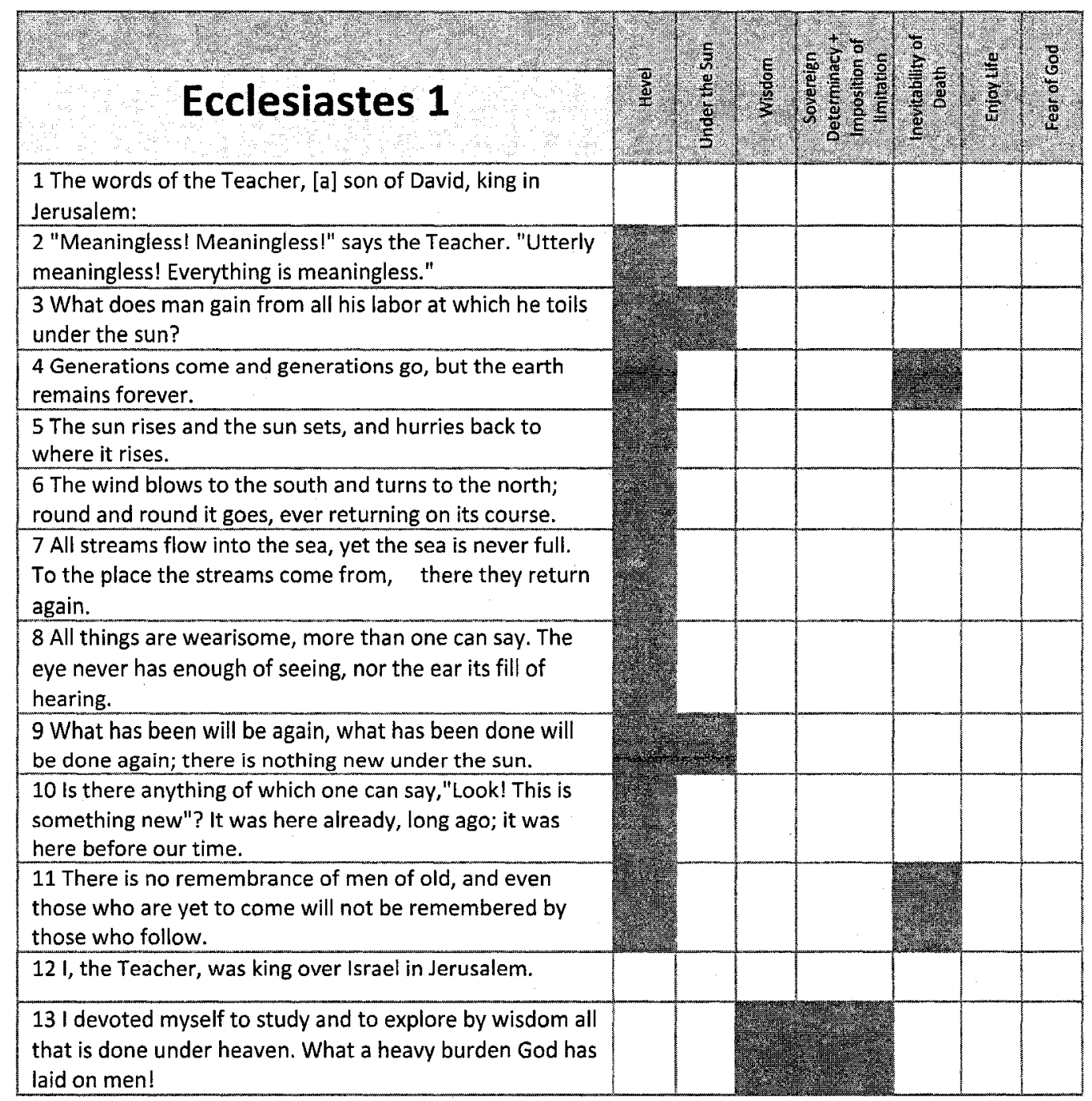




\begin{tabular}{|c|c|c|c|c|c|c|}
\hline $\begin{array}{l}14 \text { I have seen all the things that are done under the sun; } \\
\text { all of them are meaningless, a chasing after the wind. }\end{array}$ & & & & & & \\
\hline $\begin{array}{l}15 \text { What is twisted cannot be straightened; what is } \\
\text { lacking cannot be counted. }\end{array}$ & & & & & & \\
\hline $\begin{array}{l}16 \text { I thought to myself, "Look, I have grown and increased } \\
\text { in wisdom more than anyone who has ruled over } \\
\text { Jerusalem before me; I have experienced much of } \\
\text { wisdom and knowledge." }\end{array}$ & & & & & & \\
\hline $\begin{array}{l}17 \text { Then I applied myself to the understanding of wisdom, } \\
\text { and also of madness and folly, but I learned that this, too, } \\
\text { is a chasing after the wind. }\end{array}$ & & & & & & \\
\hline $\begin{array}{l}18 \text { For with much wisdom comes much sorrow; the more } \\
\text { knowledge, the more grief. }\end{array}$ & & & & & & \\
\hline (1) & tist & & 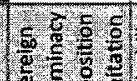 & & $\frac{2}{2}$ & (5. \\
\hline Ecclesiastes 2 & asting & & $\tan \frac{6}{6}$ & & 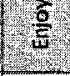 & 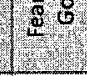 \\
\hline $\begin{array}{l}\text { 1 I thought in my heart, "Come now, I will test you with } \\
\text { pleasure to find out what is good." But that also proved } \\
\text { to be meaningless. }\end{array}$ & & & & & & \\
\hline $\begin{array}{l}2 \text { "Laughter," I said, "is foolish. And what does pleasure } \\
\text { accomplish?" }\end{array}$ & & & & & & \\
\hline $\begin{array}{l}3 \text { I tried cheering myself with wine, and embracing folly- } \\
\text { my mind still guiding me with wisdom. I wanted to see } \\
\text { what was worthwhile for men to do under heaven during } \\
\text { the few days of their lives. }\end{array}$ & & & & & & \\
\hline $\begin{array}{l}4 \text { I undertook great projects: I built houses for myself and } \\
\text { planted vineyards. }\end{array}$ & & & & & & \\
\hline $\begin{array}{l}5 \text { I made gardens and parks and planted all kinds of fruit } \\
\text { trees in them. }\end{array}$ & & & & & & \\
\hline 6 I made reservoirs to water groves of flourishing trees. & & & & & & \\
\hline $\begin{array}{l}7 \text { I bought male and female slaves and had other slaves } \\
\text { who were born in my house. I also owned more herds } \\
\text { and flocks than anyone in Jerusalem before me. }\end{array}$ & & & & & & \\
\hline $\begin{array}{l}8 I \text { amassed silver and gold for myself, and the treasure of } \\
\text { kings and provinces. I acquired men and women singers, } \\
\text { and a harem [a] as well-the delights of the heart of } \\
\text { man. }\end{array}$ & & & & & & \\
\hline $\begin{array}{l}91 \text { became greater by far than anyone in Jerusalem } \\
\text { before me. In all this my wisdom stayed with me. }\end{array}$ & & & & & & \\
\hline $\begin{array}{l}10 \text { I denied myself nothing my eyes desired; I refused my } \\
\text { heart no pleasure. My heart took delight in all my work, } \\
\text { and this was the reward for all my labor. }\end{array}$ & & & & & & \\
\hline $\begin{array}{l}11 \text { Yet when I surveyed all that my hands had done and } \\
\text { what I had toiled to achieve, everything was meaningless, } \\
\text { a chasing after the wind; nothing was gained under the } \\
\text { sun. }\end{array}$ & & & & & & \\
\hline $\begin{array}{l}12 \text { Then I turned my thoughts to consider wisdom, and } \\
\text { also madness and folly. What more can the king's } \\
\text { successor do than what has already been done? }\end{array}$ & & & & & & \\
\hline $\begin{array}{l}13 \text { I saw that wisdom is better than folly, just as light is } \\
\text { better than darkness. }\end{array}$ & & & & & & \\
\hline $\begin{array}{l}14 \text { The wise man has eyes in his head, while the fool } \\
\text { walks in the darkness; but I came to realize that the same } \\
\text { fate overtakes them both. }\end{array}$ & & & & & & \\
\hline $\begin{array}{l}15 \text { Then I thought in my heart, "The } \\
\text { overtake me also. What then do I } \mathrm{g}\end{array}$ & & & & & & \\
\hline
\end{tabular}




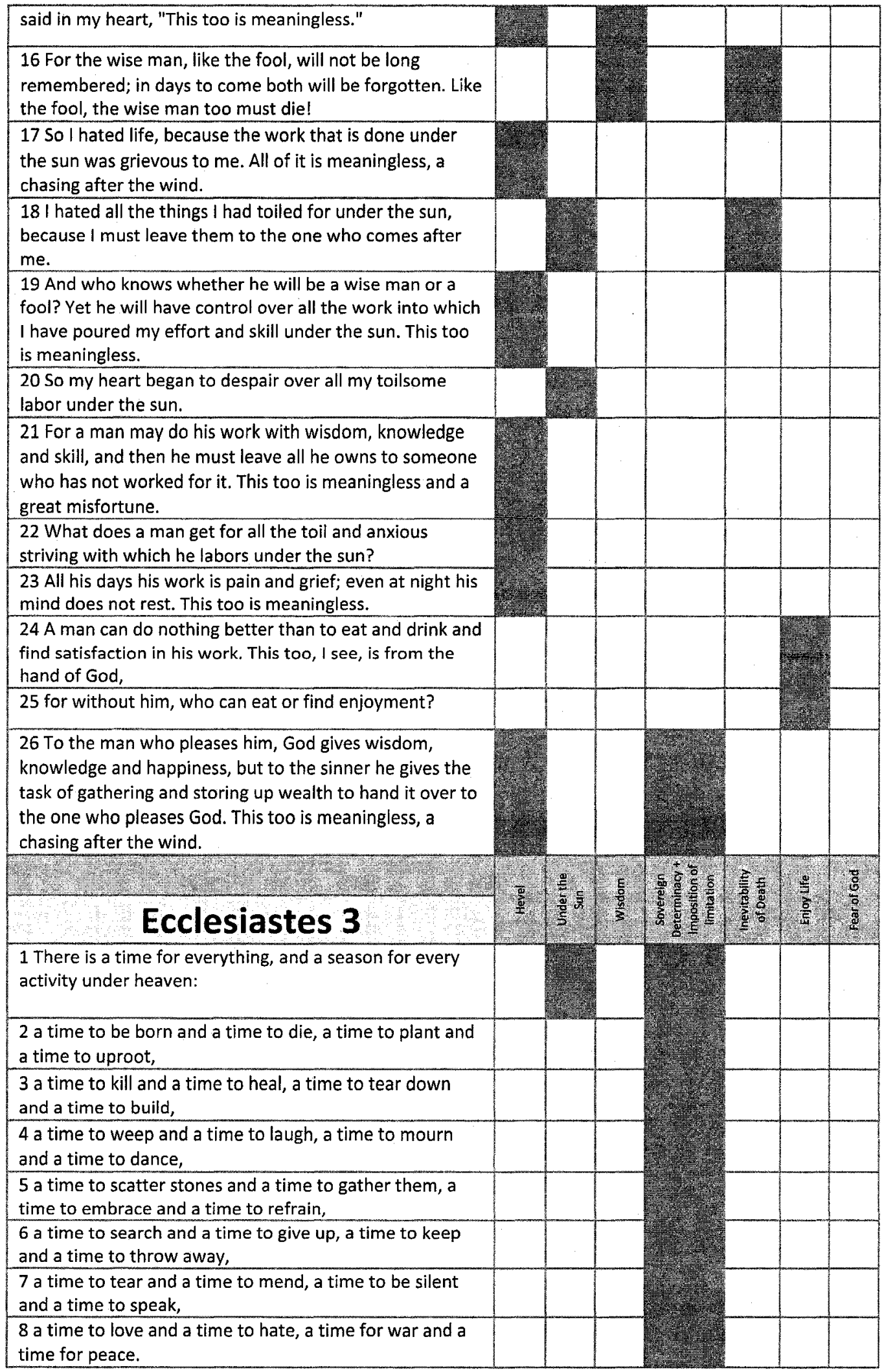




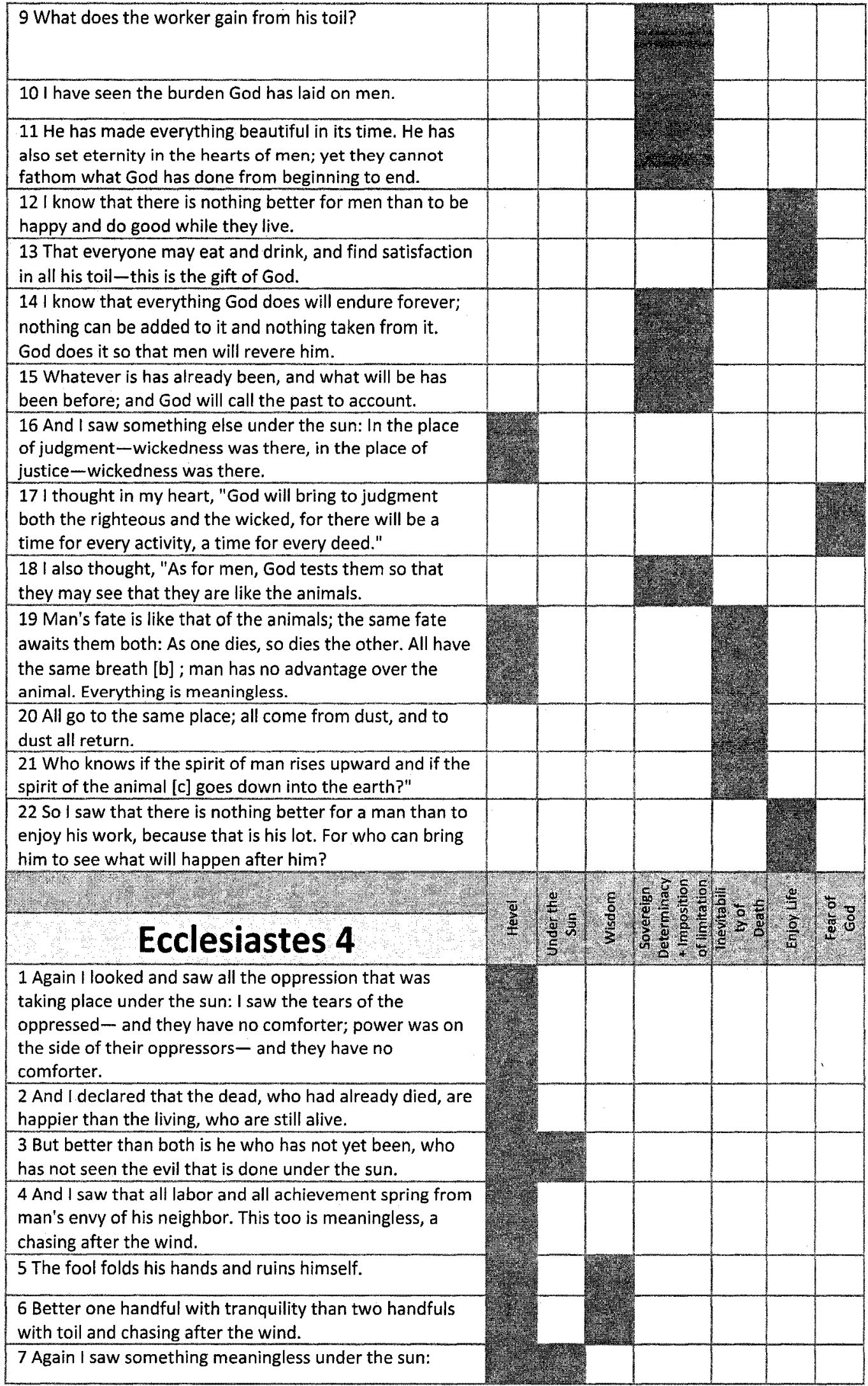




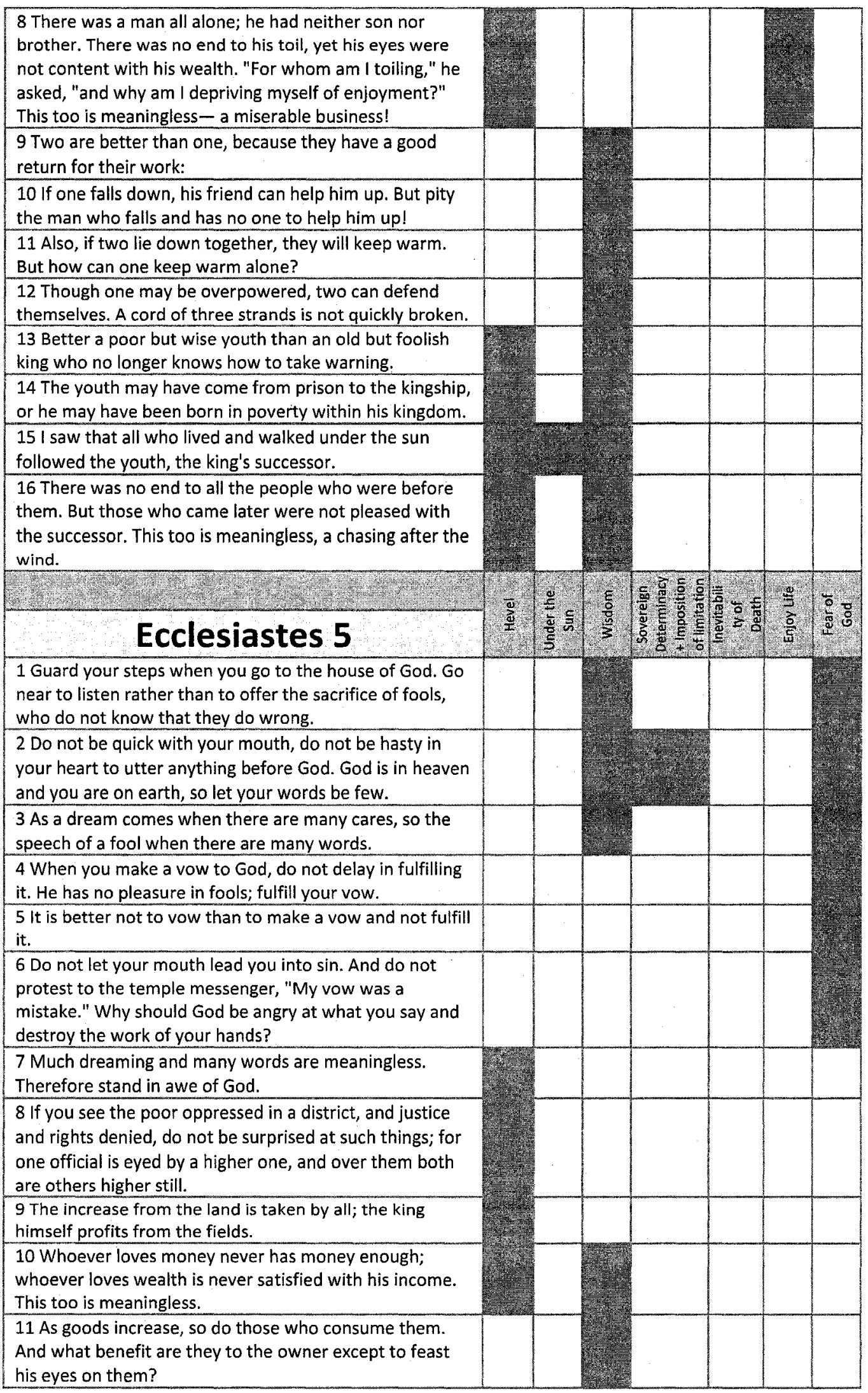




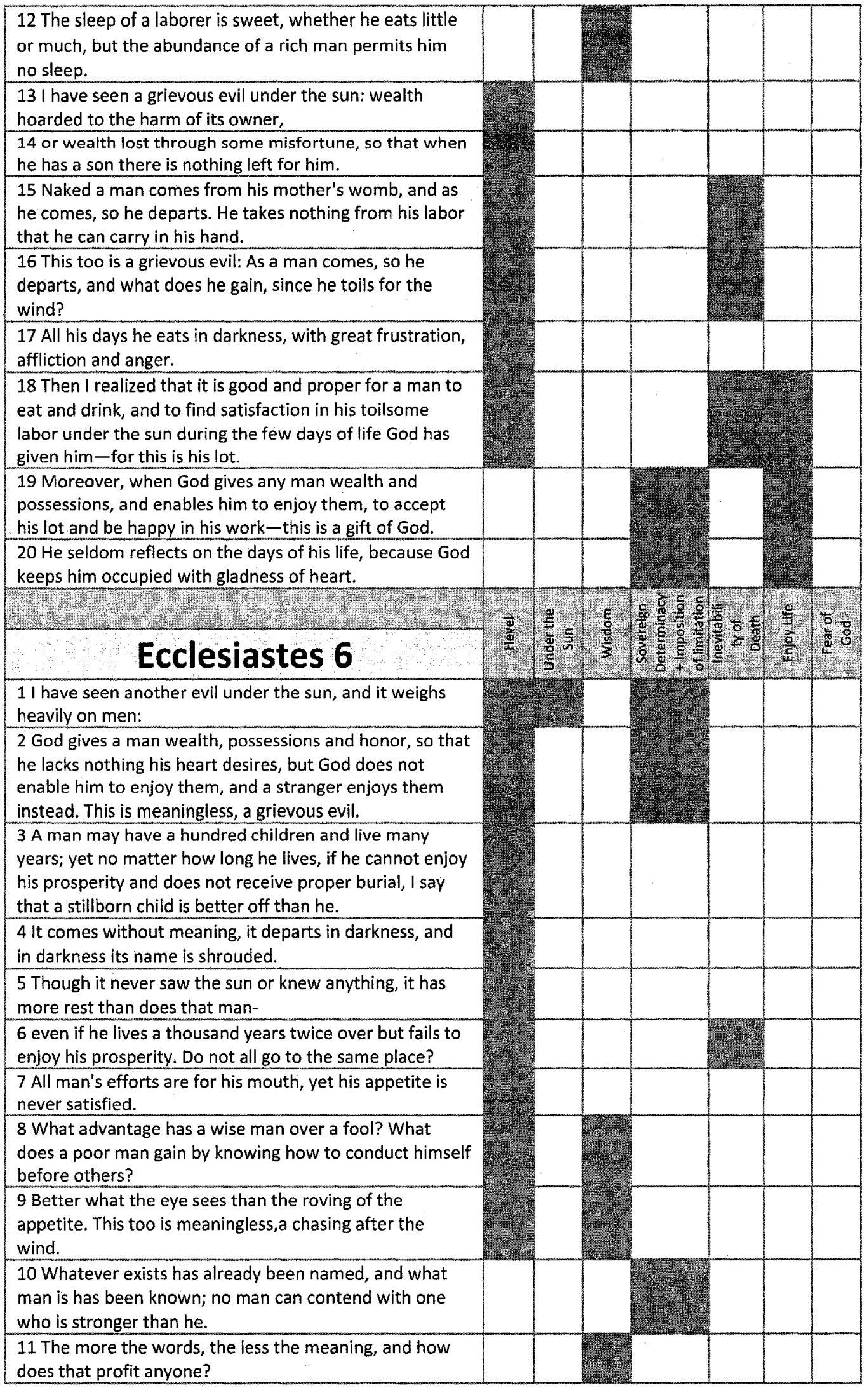




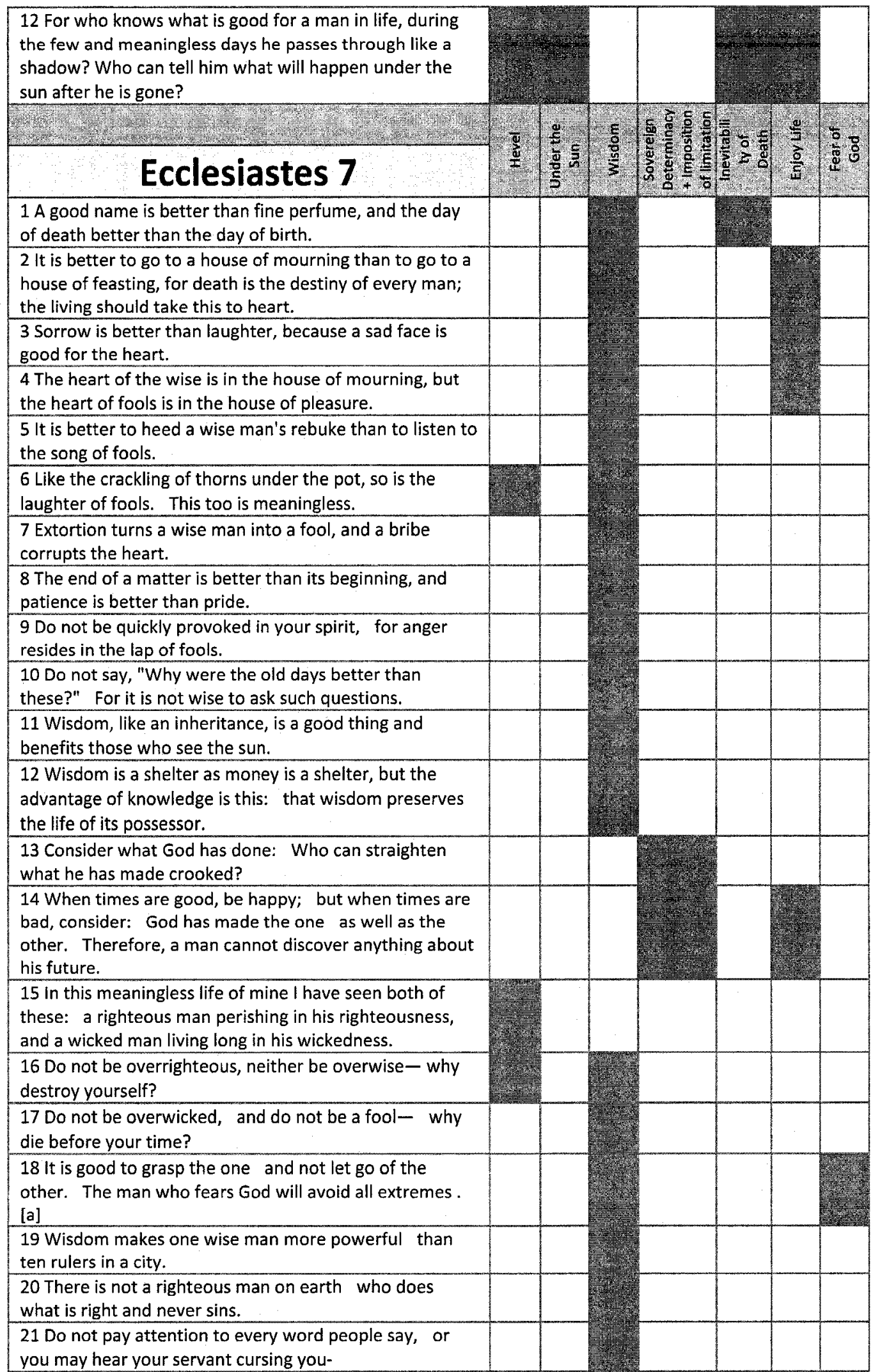




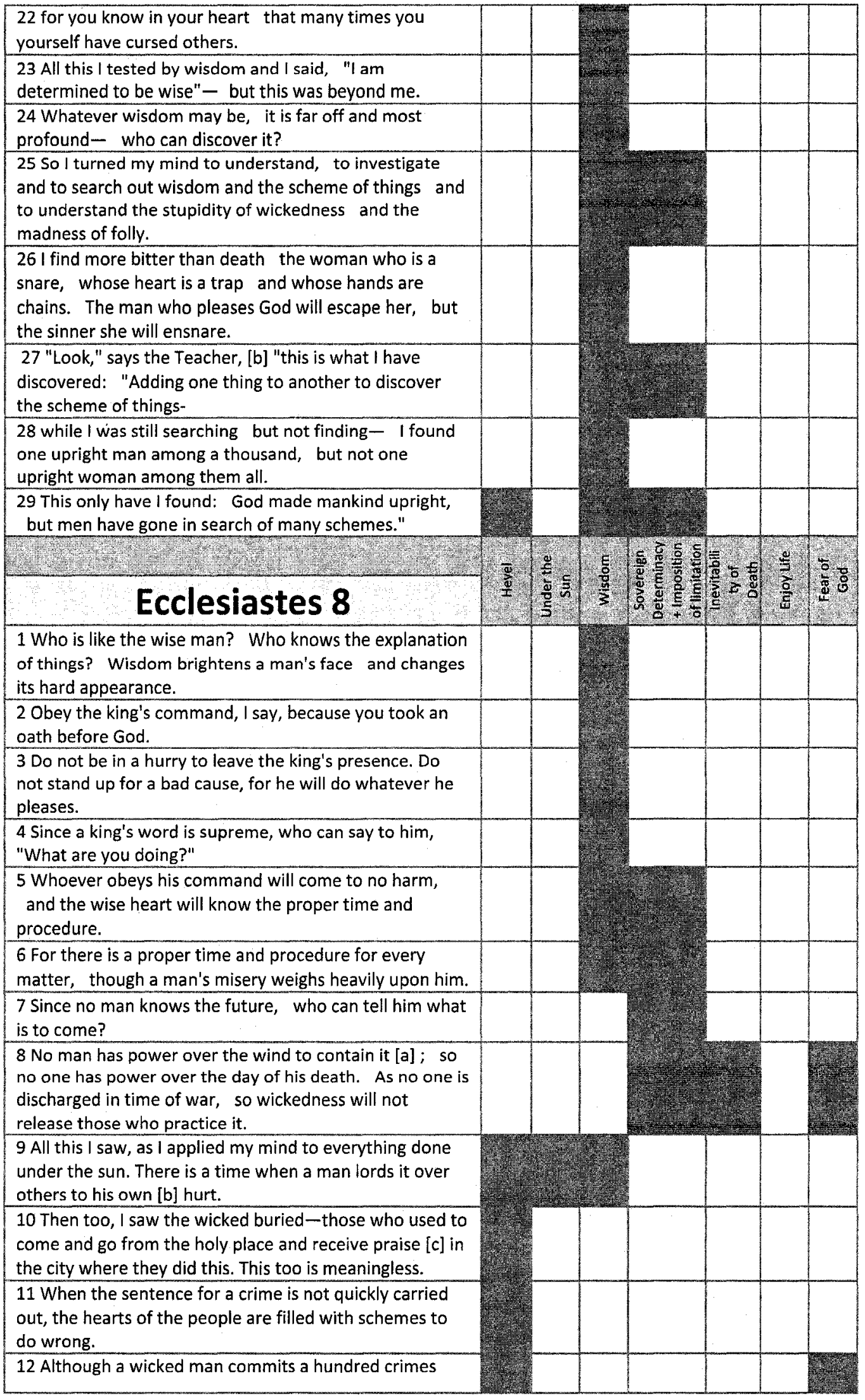




\begin{tabular}{|c|c|c|c|c|c|c|c|}
\hline \multicolumn{7}{|l|}{$\begin{array}{l}\text { and still lives a long time, I know that it will go better with } \\
\text { God-fearing men, who are reverent before God. }\end{array}$} & \\
\hline $\begin{array}{l}13 \text { Yet because the wicked do not fear God, it will not go } \\
\text { well with them, and their days will not lengthen like a } \\
\text { shadow. }\end{array}$ & & & & & & & \\
\hline \multicolumn{8}{|l|}{$\begin{array}{l}14 \text { There is something else meaningless that occurs on } \\
\text { earth: righteous men who get what the wicked deserve, } \\
\text { and wicked men who get what the righteous deserve. } \\
\text { This too, I say, is meaningless. }\end{array}$} \\
\hline \multicolumn{8}{|l|}{$\begin{array}{l}15 \text { So I commend the enjoyment of life, because nothing } \\
\text { is better for a man under the sun than to eat and drink } \\
\text { and be glad. Then joy will accompany him in his work all } \\
\text { the days of the life God has given him under the sun. }\end{array}$} \\
\hline \multicolumn{8}{|l|}{$\begin{array}{l}16 \text { When I applied my mind to know wisdom and to } \\
\text { observe man's labor on earth-his eyes not seeing sleep } \\
\text { day or night- }\end{array}$} \\
\hline \multicolumn{8}{|l|}{$\begin{array}{l}17 \text { then I saw all that God has done. No one can } \\
\text { comprehend what goes on under the sun. Despite all his } \\
\text { efforts to search it out, man cannot discover its meaning. } \\
\text { Even if a wise man claims he knows, he cannot really } \\
\text { comprehend it. }\end{array}$} \\
\hline 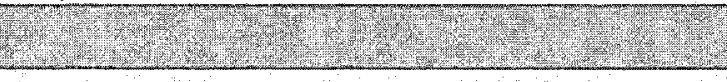 & & & $\frac{6}{6}$ & & & $\underline{3}$ & \\
\hline Ecclesiastes 9 & & & & & & a & \\
\hline \multicolumn{8}{|l|}{$\begin{array}{l}1 \text { So I reflected on all this and concluded that the } \\
\text { righteous and the wise and what they do are in God's } \\
\text { hands, but no man knows whether love or hate awaits } \\
\text { him. }\end{array}$} \\
\hline \multicolumn{8}{|l|}{$\begin{array}{l}2 \text { All share a common destiny-the righteous and the } \\
\text { wicked, the good and the bad, [a] the clean and the } \\
\text { unclean, those who offer sacrifices and those who do } \\
\text { not. As it is with the good man, so with the sinner; as } \\
\text { it is with those who take oaths, so with those who are } \\
\text { afraid to take them. }\end{array}$} \\
\hline \multicolumn{8}{|l|}{$\begin{array}{l}3 \text { This is the evil in everything that happens under the } \\
\text { sun: The same destiny overtakes all. The hearts of men, } \\
\text { moreover, are full of evil and there is madness in their } \\
\text { hearts while they live, and afterward they join the dead. }\end{array}$} \\
\hline \multicolumn{8}{|l|}{$\begin{array}{l}4 \text { Anyone who is among the living has hope }[\mathrm{b}] \text {-even a } \\
\text { live dog is better off than a dead lion! }\end{array}$} \\
\hline \multicolumn{8}{|l|}{$\begin{array}{l}5 \text { For the living know that they will die, but the dead } \\
\text { know nothing; they have no further reward, and even } \\
\text { the memory of them is forgotten. }\end{array}$} \\
\hline \multicolumn{7}{|l|}{$\begin{array}{l}6 \text { Their love, their hate and their jealousy have long } \\
\text { since vanished; never again will they have a part in } \\
\text { anything that happens under the sun. }\end{array}$} & \\
\hline \multicolumn{8}{|l|}{$\begin{array}{l}7 \text { Go, eat your food with gladness, and drink your wine } \\
\text { with a joyful heart, for it is now that God favors what you } \\
\text { do. }\end{array}$} \\
\hline \multicolumn{8}{|l|}{$\begin{array}{l}8 \text { Always be clothed in white, and always anoint your } \\
\text { head with oil. }\end{array}$} \\
\hline \multicolumn{8}{|l|}{$\begin{array}{l}9 \text { Enjoy life with your wife, whom you love, all the days of } \\
\text { this meaningless life that God has given you under the } \\
\text { sun- all your meaningless days. For this is your lot in life } \\
\text { and in your toilsome labor under the sun. }\end{array}$} \\
\hline $\begin{array}{l}10 \text { Whatever your hand finds to do, do it with all your } \\
\text { might, for in the grave, [c] where you are going, there is }\end{array}$ & & & & & & & \\
\hline
\end{tabular}




\begin{tabular}{|c|c|c|c|c|c|c|c|}
\hline neither working nor planning nor knowledge nor wisdom. & & & & & & & \\
\hline $\begin{array}{l}11 \text { I have seen something else under the sun: The race is } \\
\text { not to the swift or the battle to the strong, nor does food } \\
\text { come to the wise or wealth to the brilliant or favor to the } \\
\text { learned; but time and chance happen to them all. }\end{array}$ & & & & & & & \\
\hline $\begin{array}{l}12 \text { Moreover, no man knows when his hour will come: } \\
\text { As fish are caught in a cruel net, or birds are taken in a } \\
\text { snare, so men are trapped by evil times that fall } \\
\text { unexpectedly upon them. }\end{array}$ & & & & & & & \\
\hline $\begin{array}{l}13 \text { I also saw under the sun this example of wisdom that } \\
\text { greatly impressed me: }\end{array}$ & & & & & & & \\
\hline $\begin{array}{l}14 \text { There was once a small city with only a few people in } \\
\text { it. And a powerful king came against it, surrounded it and } \\
\text { built huge siegeworks against it. }\end{array}$ & & & & & & & \\
\hline $\begin{array}{l}15 \text { Now there lived in that city a man poor but wise, and } \\
\text { he saved the city by his wisdom. But nobody } \\
\text { remembered that poor man. }\end{array}$ & & & & & & & \\
\hline $\begin{array}{l}16 \text { So I said, "Wisdom is better than strength." But the } \\
\text { poor man's wisdom is despised, and his words are no } \\
\text { longer heeded. }\end{array}$ & & & & & & & \\
\hline $\begin{array}{l}17 \text { The quiet words of the wise are more to be heeded } \\
\text { than the shouts of a ruler of fools. }\end{array}$ & & & & & & & \\
\hline $\begin{array}{l}18 \text { Wisdom is better than weapons of war, but one } \\
\text { sinner destroys much good. }\end{array}$ & & & & & & & \\
\hline a & 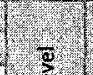 & g & & 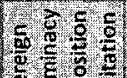 & 5. & $\frac{8}{8}$ & $\overline{0}:$ \\
\hline Ecclesiastes 10 & & $1 \frac{\pi}{5}$ & & 3. $\frac{2}{8} \frac{8}{8}$ & & ât & 58 \\
\hline $\begin{array}{l}1 \text { As dead flies give perfume a bad smell, so a little folly } \\
\text { outweighs wisdom and honor. }\end{array}$ & & & & & & & \\
\hline $\begin{array}{l}2 \text { The heart of the wise inclines to the right, but the } \\
\text { heart of the fool to the left. }\end{array}$ & & & & & & & \\
\hline $\begin{array}{l}3 \text { Even as he walks along the road, the fool lacks sense } \\
\text { and shows everyone how stupid he is. }\end{array}$ & & & & & & & \\
\hline $\begin{array}{l}4 \text { If a ruler's anger rises against you, do not leave your } \\
\text { post; calmness can lay great errors to rest. }\end{array}$ & & & & & & & \\
\hline $\begin{array}{l}5 \text { There is an evill have seen under the sun, the sort of } \\
\text { error that arises from a ruler: }\end{array}$ & & & & & & & \\
\hline $\begin{array}{l}6 \text { Fools are put in many high positions, while the rich } \\
\text { occupy the low ones. }\end{array}$ & & & & & & & \\
\hline $\begin{array}{l}7 \text { I have seen slaves on horseback, while princes go on } \\
\text { foot like slaves. }\end{array}$ & & & & & & & \\
\hline $\begin{array}{l}8 \text { Whoever digs a pit may fall into it; whoever breaks } \\
\text { through a wall may be bitten by a snake. }\end{array}$ & & & & & & & \\
\hline $\begin{array}{l}9 \text { Whoever quarries stones may be injured by them; } \\
\text { whoever splits logs may be endangered by them. }\end{array}$ & & & & & & & \\
\hline $\begin{array}{l}10 \text { If the ax is dull and its edge unsharpened, more } \\
\text { strength is needed but skill will bring success. }\end{array}$ & & & & & & & \\
\hline $\begin{array}{l}11 \text { If a snake bites before it is charmed, there is no profit } \\
\text { for the charmer. }\end{array}$ & & & & & & & \\
\hline $\begin{array}{l}12 \text { Words from a wise man's mouth are gracious, but a } \\
\text { fool is consumed by his own lips. }\end{array}$ & & & & & & & \\
\hline $\begin{array}{l}13 \text { At the beginning his words are folly; at the end they } \\
\text { are wicked madness- }\end{array}$ & & & & & & & \\
\hline $\begin{array}{l}14 \text { and the fool multiplies words. No one knows what is } \\
\text { coming - who can tell him what will happen after him? }\end{array}$ & & & & & & & \\
\hline
\end{tabular}




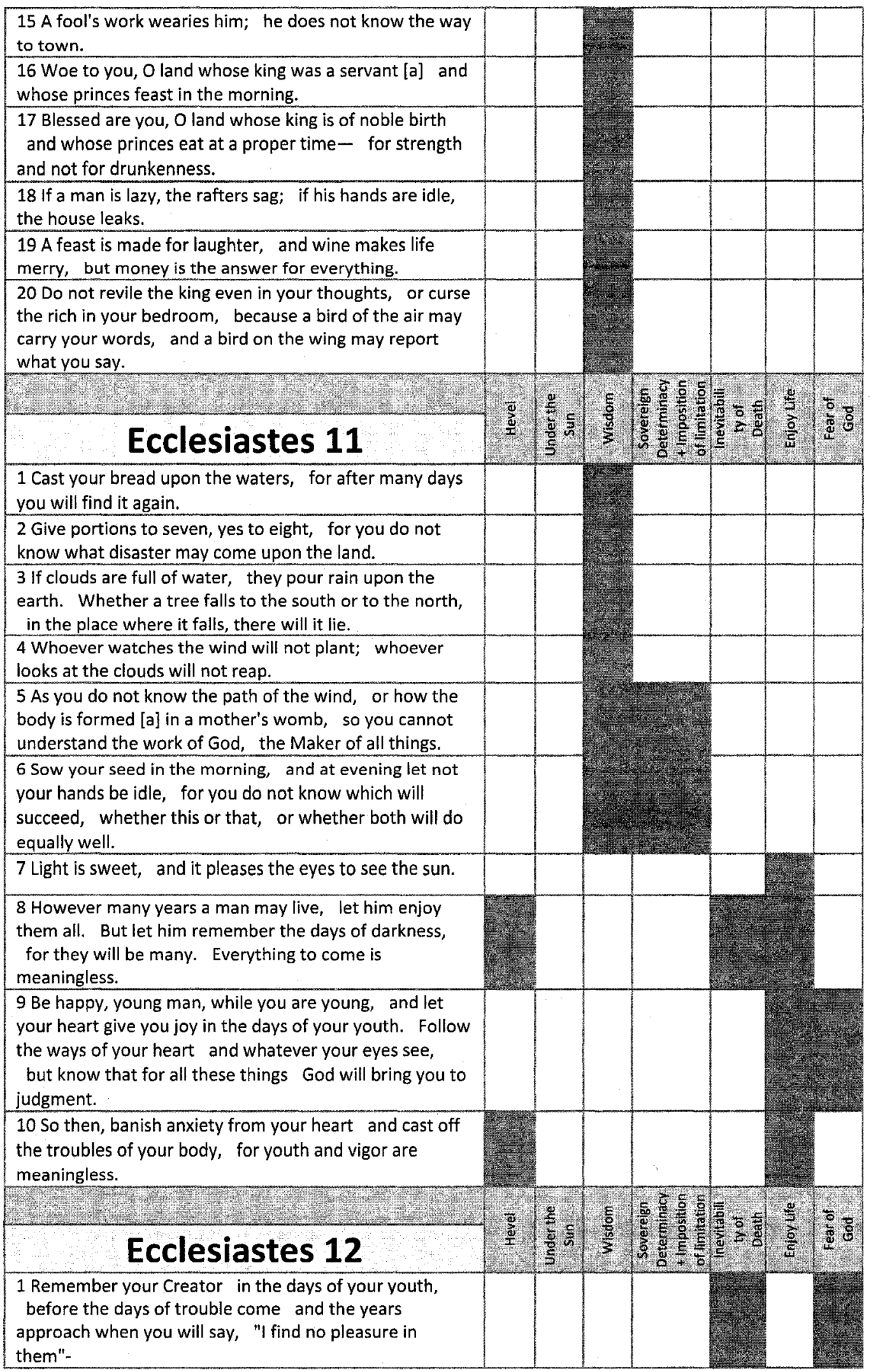




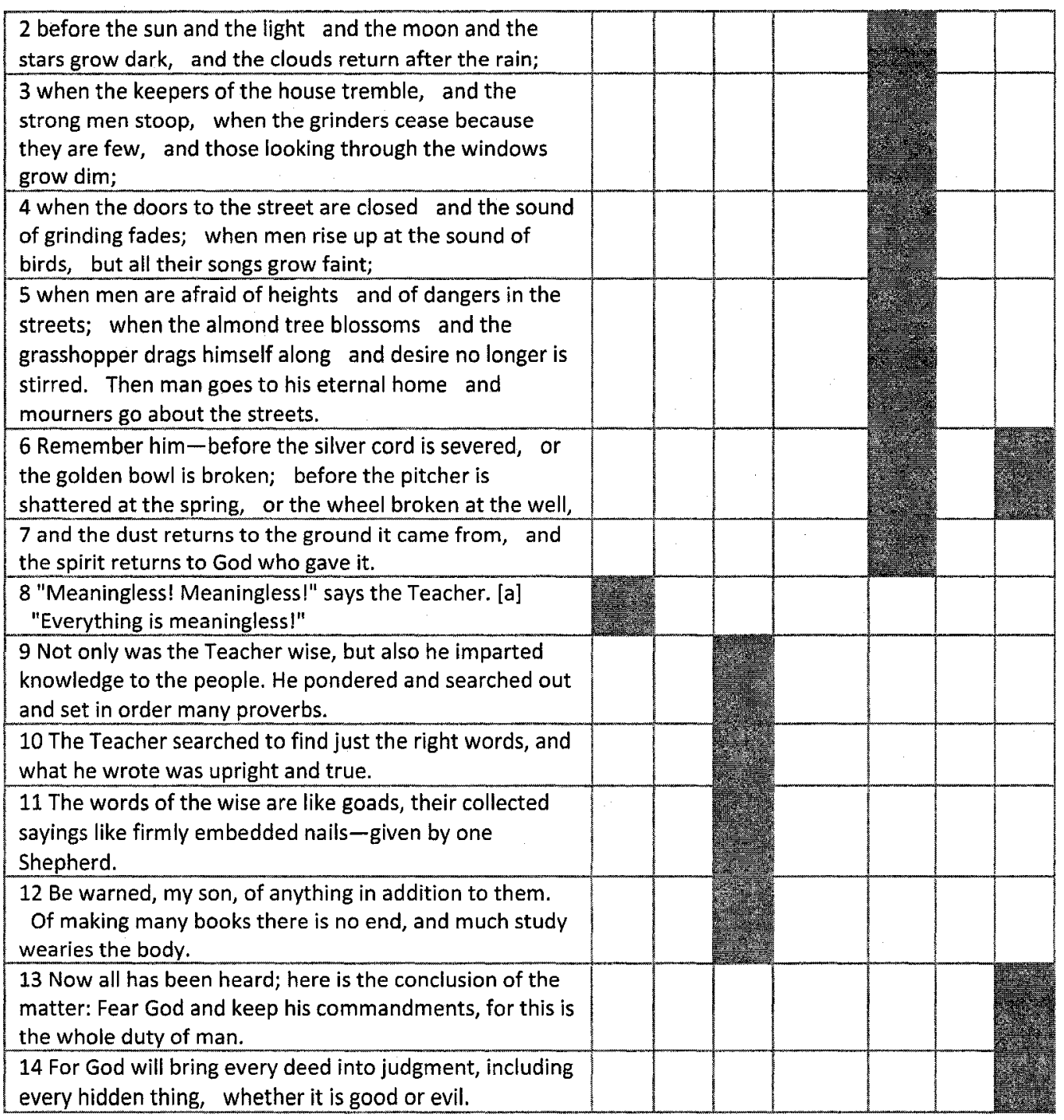




\section{BIBLIOGRAPHY}

Anderson, Gary. A Time to Mourn, a Time to Dance. University Park: Pennsylvania State University Press, 1991.

Anderson, William H. U. Qohelet and Its Pessimistic Theology: Hermeneutical Struggles in Wisdom Theology. Lewiston, New York: Edwin Mellen Press, 1997.

Archer, Gleason L. "The Linguistic Evidence for the Date of 'Ecclesiastes," Journal of the Evangelical Theological Society 12 (1969): 167-81.

Armstrong, James F. "Ecclesiastes in Old Testament Theology." Princeton Seminary Bulletin 94 (1983): 16-25.

Arnold, Bill T. and John H. Choi, A Guide to Biblical Hebrew Syntax. New York: Cambridge, 2003.

Backhaus, Franz J. "Denn Zeit und Zufall trifft sie alle": Studien zur Komposition und zum Gottesbild im Buch Qohelet. Bonner biblische Beitrage 83. Frankfurt am Main: Anton Hain, 1993.

Bailey, Lloyd R. Sr. Biblical Perspectives on Death. Philadelphia: Fortress Press, 1979.

Baker, David W. and Bill T. Arnold, eds. The Face of Old Testament Studies: A Survey of Contemporary Approaches. Grand Rapids: Baker, 1999.

Barre, Michael L. "Fear of God and the World View of Wisdom." Biblical Theology Bulletin 11-13 (1983): 41-43.

Bartholomew, Craig G. Reading Ecclesiastes: Old Testament Exegesis and Hermeneutical Theory. Analecta Biblica 139. Rome: Editrice Pontificio Istituto Biblico, 1998.

Barton, G. A. A Critical and Exegetical Commentary on the Book of Ecclesiastes. International Critical Commentary. Edinburgh: T \& T Clark, 1912.

Barton, John. Reading the Old Testament: Method in Biblical Study. $2^{\text {nd }}$ ed. revised Louisville: Westminster John Knox, 1996.

Beal, Timothy K. and Tod Linafelt, eds. God in the Fray: A Tribute to Walter Brueggeman. Minneapolis: Augsburg Fortress, 1998. 
Bell, R.D. "Structure and Themes of Ecclesiastes." Biblical Viewpoint 31 (1997): 3-9.

Berger, Benjamin Lyle. "Qohelet and the Exigencies of the Absurd." Biblical Interpretation 9 no 2 (2001): 141-79.

Berlin, Adele. Poetics and Interpretation of Biblical Narrative. Sheffield, England: Almond, 1983.

Berry, Donald K. An Introduction to Wisdom and Poetry of the Old Testament. Nashville: Broadman and Holman, 1999.

Bianchi, F. "The Language of Qoheleth: A Bibliographical Survey." Zeitschrift für die alttestamentliche Wissenschaft 105 (1993): 210-11.

Bickerman, Elias J. Four Strange Books of the Bible: Jonah, Daniel, Koheleth, Esther. New York: Schocken Books, 1967.

Blenkinsopp, Joseph. "Ecclesiastes 3:1-15: Another Interpretation." Journal for the Study of the Old Testament 66 (1995): 55-64.

Bloch-Smith, Elizabeth. Judahite Burial Practices and Beliefs about the Dead. Sheffield: Journal for the Study of the Old Testament Press, 1992.

Booth, Wayne. A Rhetoric of Irony. Chicago: University of Chicago, 1974.

Botterweck, G. Johannes and Helmer Ringgren. Theological Dictionary of the Old Testament Vol. 3. Grand Rapids: Eerdmans, 1978.

. Theological Dictionary of the Old Testament, Vol. 6. Grand Rapids:

Eerdmans, 1990.

Bream, Howard N. "Life without Resurrection: Two Perspectives from Qoheleth." Pages 49-63 in A Light unto My Path. H. N. Bream, ed. Philadelphia: Temple University Press, 1974.

Brenz, Johannes. Der Prediger Salomo: Faksimile-Neudruck der ersten Ausgabe Hagenau 1528. Stuttgart: Frommann, 1970.

Breton, S. "Qohelet in Recent Studies." Theology Digest 28 (1980): 147-51.

Bretschnieder, C. G. ed. Corpus Reformatorium. Halle: Schwetschke, 1847.

Brindle, Wayne A. Righteousness and Wickedness in Ecclesiastes 7:15-18." Andrews University Seminary Studies 23 no. 3 (1985): 243-57. 
Brown, F., S. Driver, and C. Briggs. The Brown-Driver-Briggs Hebrew and English Lexicon. $6^{\text {th }}$ ed. Peabody, Massachusetts: Hendrickson, 2001.

Brown, William P. Ecclesiastes. Interpretation. Louisville: John Knox Press, 2000.

."Whatever Your Hand Finds to Do: Qohelet's Work Ethic." Interpretation 55 no. 3 (2001): 271-84.

Burkes, Shannon. Death in Qoheleth and Egyptian Biographies of the Late Period. Atlanta: Society of Biblical Literature, 1999.

Caird, G. B. The Language and Imagery of the Bible. Philadelphia: Westminster, 1980.

Carasik, Michael. "Qohelet's Twists and Turns." Journal for the Study of the Old Testament 28 no. 2 (2003): 192-209.

Carny, P. "Theodicy in the Book of Qohelet." Pages 71-81 in Justice and Righteousness: Biblical Themes and Their Influence, H. G. Reventlow and Y. Hoffman, eds. Sheffield, England: JSOT Press, 1992.

Castellino, George R. "Qohelet and His Wisdom." Catholic Biblical Quarterly 30 (1968): 15-28.

Childs, Bernard. Introduction to the Old Testament as Scripture. Minneapolis: Fortress, 1979.

Chouraqui, Andre. La Bible, traduite et presentee par Andre Chouraqui. Paris: Desclee de Brouwer, 1975.

Christianson, E. S. A Time to Tell: Narrative Strategies in Ecclesiastes, JSOT 280 Sheffield, England: Sheffield Academic Press, 1998.

Clemens, D. M. "The Law of Sin and Death: Ecclesiastes and Genesis 1-3." Themelios 19 (1994): 5-8.

Clifford, Richard J. The Wisdom Literature. Interpreting Biblical Texts. Nashville: Abingdon, 1998.

Clines, David J. A. and J. Cheryl Exum, eds. The New Literary Criticism and the Hebrew Bible. Valley Forge, Pennsylvania: Trinity Press International, 1993.

Clemens, D. M. "The Law of Sin and Death: Ecclesiastes and Genesis 1-3." Themelios 19 (1994): 5-8.

Collins, John J. "Apocalyptic Eschatology as the Transcendence of Death." Catholic Biblical Quarterly 36 (1974): 21-43. 
. Daniel. Minneapolis: Fortress Press, 1993.

Cooper, John W. Body, Soul, and Life Everlasting: Biblical Anthropology and the Monism-Dualism Debate. Grand Rapids: Eerdmans, 1989.

Crenshaw, James L. Ecclesiastes. The Old Testament Library. Philadelphia: Westminster Press, 1987.

. "The Expression Mi Yodea in the Hebrew Bible." Vetus Testamentum 36 no 3 (1986): 274-88.

\section{1.}

Old Testament Wisdom: An Introduction. Atlanta: John Knox Press,

. "In Search of a Divine Presence: Some Remarks Preliminary to a Theology of Wisdom." Review and Expositor 74 (1977): 353-69.

."The Shadow of Death in Qohelet," 205-216 in Israelite Wisdom:

Theological and Literary Essays in Honor of Samuel Terrien, ed. John G. Gammie. New York: Union Theological Seminary, 1978.

Crenshaw, James L. and S. Sandmel. The Divine Helmsman: Studies on God's Control of Human Events. New York: KTAV, 1980.

Crusemann, F. "The Unchangeable World: the 'Crisis of Wisdom' in Koheleth." Pages 57-77 in The God of the Lowly: Socio-historical Interpretations of the Bible, W. Schottroff and W. Stegemann, eds. Translated by M.J.O'Connell. Maryknoll: Orbis, 1984.

Curkpatrik, Stephen. "A Disciple for Our Time: A Conversation." Interpretation 55 no. 3 (2001): 285-91.

Curtis, Edward M. and John J. Brugaletta. Discovering the Way of Wisdom: Spirituality in the Wisdom Literature. Grand Rapids: Kregal, 2004.

Dahood, M. H. “Canaanite-Phoenician Influence in Qoheleth.” Biblica 33 (1952): 30-52, 191-221.

_. "The Language of Qoheleth." Catholic Biblical Quarterly 14 (1952): 227-32.

. "The Phoenician Background of Qoheleth." Biblica 47 (1966): 264-82.

Davis, B. C. "Ecclesiastes 12:1-8-Death, an Impetus for Life." Bibliothecra Sacra 148 (1991): 298-317. 
DeHaan, Richard W. The Art of Staying Off Dead-End Streets. Wheaton, IL: Victor Books, 1974.

DeJong, Stephen. "A Book of Labour: The Structuring Principles and the Main Theme of the Book of Qoheleth." Journal for the Study of the Old Testament 54 (1992): 107-16.

Delitzsch, F. Ecclesiastes. Reprint of English ed. Grand Rapids: Eerdmans, 1982.

Dell, Katharine J. "Ecclesiastes as Wisdom: Consulting Early Interpreters." Vetus Testamentum 44 no. 3 (1994): 301-29.

Dell, Katharine J. and Margaret Barker, eds. Wisdom: The Collected Articles of Norman Whybray. Burlington, VT: Ashgate Publishing Company, 2005.

deSilva, David A., Introducing the Apocrypha: Message, Context, and Significance. Grand Rapids: Baker Academic, 2002.

Dillard, R. B. and Tremper Longman III. An Introduction to the Old Testament. Grand Rapids: Zondervan, 1994.

Dulin, Rachel Z. "How Sweet is the Light: Qoheleth's Age Centered Teachings." Interpretation 55 no 3 (2001): 260-70.

Eaton, Michael A. Ecclesiastes: An Introduction and Commentary. Tyndale Old Testament Commentaries. Downers Grove: Intervarsity, 1983.

Ehlich, K. "Hebel-Mataphern der Nichtigkeit." Pages 49-64 in "Jedes Ding hat seine Zeit... ." Studien zur israelitischen und altorientalischen Weisheit. A. A. Diesel, ed. BZAW 241. Berlin: Walter de Gruyter, 1996.

Ehlke, Roland C. Ecclesiastes/Song of Songs, Revised ed. People's Bible Commentary. Saint Louis: Concordia Publishing House, 2004.

Ellul, Jacques. Reason for Being: A Meditation on Ecclesiastes. Grand Rapids: Eerdmans, 1990.

Enns, Peter. Inspiration and Incarnation: Evangelicals and the Problem of the Old Testament. Grand Rapids: Baker Academic, 2005.

Estes, Daniel. Handbook on the Wisdom Books and Psalms. Grand Rapids: Baker Academic, 2005.

Farmer, Kathleen A. Who Knows What Is Good? A Commentary on the Books of Proverbs and Ecclesiastes. International Theological Commentary. Grand Rapids: W. B. Eerdmans Publishing Co., 1991. 
Fee, Gordon D. and Douglas Stuart. How to Read the Bible for All Its Worth, $2^{\text {nd }}$ revised ed. Grand Rapids: Zondervan, 1993.

Fisch, H. Poetry with a Purpose: Biblical Poetics and Interpretation. Indianapolis: Indiana University Press, 1988.

Fishbane, Michael. Biblical Interpretation in Ancient Israel. Oxford: Clarendon Press, 1985.

Fobert, Glenn. Everything Is Mist: Ecclesiastes on Life in a Puzzling and Troubled Temporary World. Belleville, Canada: Guardian Books, 2003.

Fontaine, Carole R. "Wisdom Traditions in the Hebrew Bible." Dialogue 33 no. 1 (2000): 101-17.

Forman, C. G. "Koheleth's Use of Genesis." Journal of Semitic Studies 5 (1960): 256-63. . “The Pessimism of Ecclesiastes." Journal of Semitic Studies 3 (1958): 336-43.

Fox, Michael V. "Aging and Death in Qohelet 12," Journal for the Study of the Old Testament 42 (1988): 55-77.

. "Frame-narrative and Composition in the Book of Qohelet." Hebrew Union College Annual 48 (1977): 83-106.

(1986): 409-27.

Almond, 1989.

Qohelet and His Contradictions. JSOTup 71. Sheffield, England:

. "Qohelet's Epistomology." Hebrew Union College Annual 58 (1987):

137-55.

. A Time to Tear Down and A Time to Build Up: A Rereading of

Ecclesiastes. Grand Rapids: Eerdmans, 1999.

Fredericks, Daniel C. Coping with Transience: Ecclesiastes on Brevity in Life. Biblical Seminar 18. Sheffield, England: JSOT Press, 1993.

. Qoheleth's Language: Re-evaluating Its Nature and Date. Lewiston, NY:

Edwin Mellen, 1988.

Frei, Hans W. The Eclipse of Biblical Narrative: A Study in Eighteenth and Nineteenth Century Hermeneutics. New Haven and London: Yale University Press, 1974. 
Frydrych, Tomas. Living Under the Sun: Examination of Proverbs and Qoheleth. Leiden, Netherlands: Brill, 2002.

Galling, Kurt. “Der Prediger." In Die fünf Megilloth. $2^{\text {nd }}$ revised ed. Handbuch zum Alten Testament 18. Tübingen: Mohr, 1969.

Gammie, John G. "Stoicism and anti-Stoicism in Qoheleth." Hebrew Annual Review 9 (1985): 169-87.

Garrett, Duane A. Proverbs, Ecclesiastes, Song of Songs. New American Commentary. Nashville: Broadman Press, 1993.

Gatch, Milton McC. Death: Meaning and Mortality in Christian Thought and Contemporary Culture. New York: Seabury Press, 1969.

Gerson, Adolf. Der Chacham Kohelet als Philosoph und Politiker: Ein Kommentar zum biblischen Buche Kohelet, zugleich eine Studie zur religiosen und politischen Entwicklung des Volkes Israel im Zeitalter Herodes des Grossen. Frankfurt am Main: Kauffmann, 1905.

Gensenius, trans. Samuel Prideaux Tregelles, Hebrew and Chaldee Lexicon. Grand Rapids: Baker, 1979.

Gianto, A. "The Theme of Enjoyment in Qohelet." Biblica 73 (1992): 528-33.

Gilbert, M. "La description de la vielliesse en Qohelet XII 1-7 est-elle allegorique?" Congress Volume, Vienna, 1980. VTSup 32 Lieden: Brill, 1981.

Ginsberg, H. L. Koheleth. Jerusalem: Newman, 1961.

Glasson, T. Francis. "You Never Know': The Message of Ecclesiastes 11:1-6." Evangelical Quarterly 55 (1983): 43-48.

Goldberg, Louis. Ecclesiastes, Bible Study Commentary. Grand Rapids, Zondervan, 1983.

Good, Edwin. Irony in the Old Testament. Sheffield: Almond Press, 1981.

Gordis, Robert. Koheleth, the Man and His World: A Study of Ecclesiastes. $3^{\text {rd }}$ augmented ed. New York: Schocken Books, 1968.

Gualtieri, Antonio R. The Vulture and the Bull: Religious Responses to Death. Lanham, Maryland: University Press of America, 1984.

Hagedorn, Dieter, Rudolf Kassel, Ludwig Koenen, and Reinhold Merkelbach, eds. Papyrologische Texte und Abhandlungen. Bonn: Habelt, 1968. 
Hafemann, Scott J., ed. Biblical Theology: Retrospect and Prospect. Downers Grove, Illinois: Intervarsity Press, 2002.

Hallo William W., ed. Context of Scripture: Monumental Inscriptions from the Biblical World. Leiden: Brill, 2000.

Harris, R. Laird. "The Meaning of the Word Sheol as Shown by Parallels in Poetic Texts." Bulletin of the Evangelical Theological Society 4 (1961): 129-34.

Harrison, C. Robert. "Qohelth in Socio-historical Perspective." Ph.D. diss., Duke University, 1991.

Harrison, R. K. Introduction to the Old Testament. Grand Rapids: Eerdmans, 1969.

Hay, A. P. "Qohelet and the Book of Creation." Journal for the Study of the Old Testament. 50 (1991): 93-111.

Hays, J. Daniel. "Verb Forms in the Expository Discourse Sections of Ecclesiastes." Journal of Translation and Textlinguistics 7 (1995): 9-18.

Hendricks, Howard G. and William D. Hendricks. Living by the Book. Chicago: Moody, 1991.

Hengstenberg, Ernest W. A Commentary on Ecclesiates. Eugene, Oregon: Wipf and Stock Publishers, 1977 (original, 1860).

Heine, Ronald E. Fathers of the Church: A New Translation. Washington, D.C.: Catholic University of America Press, 1982.

Hertzberg, H. W. Der Prediger. Kommentar zum Alten Testament 17/4 Gutersloh: Mohn, 1963.

Hill, Andrew E. and John H. Walton. A Survey of the Old Testament. $2^{\text {nd }}$ revised ed. Grand Rapids: Zondervan, 2000.

Hirsh, E.D., Jr. Validity in Interpretation. New Haven: Yale, 1967.

Holloway, Gary. The Main Thing: A New Look at Ecclesiastes. Abilene, TX: ACU Press, 1997.

Holm-Nielson, Svend. "On the Interpretation of Qoheleth in Early Christianity." Vetus Testamentum 24 (1974): 168-77.

Horne, Milton P. Proverbs-Ecclesiastes. Smyth and Helwys Bible Commentary. Macon, Georgia: Smyth and Helwys, 2003. 
Hubbard, David A. Ecclesiastes, Song of Solomon. The Communicator's Commentary, Vol. 15b. Dallas: Word Books, 1991.

Ingram, Doug. Ambiguity in Ecclesiastes. Library of Hebrew Bible Old Testament Studies. New York: T\&T Clark, 2006.

Isakson, B. Studies in the Language of Qoheleth: With Special Emphasis on the Verbal System. Studia Semitica Upsaliensia 10. Stockholm: Almqvist and Wiksell, 1987.

Iser, Wolfgang. "Indeterminancy and the Reader's Response." Pages 226-31 in Twentieth Century Literary Theory, K. M. Newton, ed. (New York: Columbia University Press, 1971.

Jenks, Alan W. "Theological Presuppositions of Israel's Wisdom Literature." Horizons in Biblical Theology 7, no. 1 (1985): 43-75.

Jenni, Ernst and Claus Westermann. Theological Lexicon of the Old Testament, Vol 1. Peabody, Massachusetts: Hendrickson, 1997.

Johnston, Phillip S. Shades of Sheol: Death and Afterlife in the Old Testament. Downers Grove, Illinois: Intervarsity, 2002.

Johnston, Robert K. "Confessions of a Workaholic: A Reappraisal of Qoheleth." Catholic Biblical Quarterly 38 (1976): 14-28.

Jong, Stephan de. "A Book on Labour: The Structuring Principles and the Main Theme of the Book of Qohelet." Journal for the Study of the Old Testament 54 (1992): 107-16.

Kaiser, Walter C. Ecclesiastes: Total Life. Chicago: Moody Press, 1979.

Kaiser, Walter C and Ronald F. Youngblood. A Tribute to Gleason Archer: Essays on the Old Testament. Chicago: Moody, 1986.

Kelley, Michael W. The Burden of God: Studies in Wisdom and Civilization from the Book of Ecclesiastes. Minneapolis: Contra Mundum Books, 1993.

Kidner, Derek. The Message of Ecclesiastes: A Time to Mourn, and a Time to Dance. Downers Grove, IL: Intervarsity, 1976.

Koh, Y. V. Royal Autobiography in the Book of Qohelet. Berlin, Germany: Walter de Gruyter, 2006.

Koosed, Jennifer L. (Per)Mutations of Qohelet: Reading the Body in the Book. New York, T\&T Clark, 2006. 
Kruger, Thomas. Qoheleth. Hermeneia-A Critical and Historical Commentary on the Bible. Minneapolis: Fortress Press, 2004.

Lauha, Aarre. Kohelet. Biblischer Kommentar: Altes Testament 19. Neukirchen-Vluyn: Neukirchener, 1978.

Leahy, Michael. "The Meaning of Ecclesiastes 12:1-5," Irish Theological Quarterly 19 (1952): 297-300.

Lee, Eunny P. The Vitality of Enjoyment in Qohelet's Theological Rhetoric. Berlin, Germany: Walter de Gruyter, 2005.

Lichtheim, M. "The Songs of the Harpers," Journal of Near Eastern Studies 4 (1945): 178-212.

Leupold, H. C. Exposition of Ecclesiastes. Grand Rapids: Baker Book House, 1952.

Levine, E. The Aramaic Version of Qohelet. New York: Sepher-Hermon, 1978.

. "Qohelet's Fool: A Composite Portrait." Pages 277-94 in On Humour and the Comic in the Hebrew Bible, Y. T. Radday, ed. Sheffield: Almond Press, (1990): 27794.

Lohfink, Norbert. Qoheleth: A Continental Commentary. Translated by Sean McEvenue. Minneapolis: Fortress Press, 2003.

. "Qohelet 5:17-19-Revelation by Joy." Catholic Biblical Quarterly 52 (1990): 625-35.

Longman III, Tremper. The Book of Ecclesiastes. The New International Commentary on the Old Testament. Grand Rapids: Eerdmans, 1998.

. Fictional Akkadian Autobiography Winona Lake, IN: Eisenbrauns, 1991.

Loretz, O. "Zur Darbietungsform der 'Ich-Erzahlung' im Buche Qohelet," Catholic Biblical Quarterly 25 (1963): 46-59.

Lowth, Robert. Lectures on the Sacred Poetry of the Hebrews. Lecture 24. Boston: Buckingham, 1815.

Maltby, A. "The Book of Ecclesiastes and the After-Life." Evangelical Quarterly 35 (1963): 39-44.

Martin-Achard, Robert. From Death to Life. Edinburgh and London: Oliver and Boyd, 1960. 
Mays, J. L. Old Testament Interpretation: Past; Present, and Future. Nashville: Abingdon, 1995.

McKenna, John E. "The Concept of Hebel in the Book of Ecclesiastes." Scottish Journal of Theology 45 (1998): 19-28.

McKenzie, Steven L. and M. Patrick Graham, eds. The Hebrew Bible Today: An Introduction to Critical Issues. Louisville: Westminster John Knox, 1998.

McNeile, A. H. An Introduction to Ecclesiastes. Cambridge: Cambridge University, 1904.

Meek, Theophile J. "Translating the Hebrew Bible." Journal of Biblical Literature 79 (1960): 329-35.

Metzger, Bruce M. The Bible in Translation. Grand Rapids: Baker Academic, 2001.

Meyers, Jeffrey. A Table in the Mist: Meditations on Ecclesiastes. Monroe, Louisiana: Athanasius Press, 2006.

Michel, Diethelm. Qohelet. Ertäge der Forschung 258. Darmstadt: Wissenschaftliche Buchgesellschaft, 1988.

. Untersuchungen zur Eigenart des Buches Qohelet. Beihefte zur Zeitschrift für die alttestamentliche Wissenschaft 183. Berlin: de Gruyter, 1989.

Miller, Douglas B. "Qohelet's Symbolic Use of הבל,", Journal of Biblical Literature 117, no. 3 (1998): 437-54.

. Symbol and Rhetoric in Ecclesiastes: The Place of Hebel in Qohelet's Work. Atlanta: Society of Biblical Literature, 2002.

."What the Preacher Forgot: The Rhetoric of Ecclesiastes." Catholic Biblical Quarterly 62 no. 2 (2000): 215-35.

Mills, Mary E. Reading Ecclesiastes: A Literary and Cultural Exegesis. Aldershot, England: Ashgate Publishing Limited, 2003.

Moore, David George and Daniel L. Akin. Ecclesiastes, Song of Songs. Holman Old Testament Commentary. Nashville: Broadman and Holman, 2003.

Moore, T. M. Ecclesiastes: Ancient Wisdom when All Else Fails. A New Translation and Interpretive Paraphrase. Downers Grove: Intervarsity, 2001.

Muilenberg, J. "A Qoheleth Scroll from Qumran." Bulletin of the American Schools of Oriental Research 135 (1954): 20-28 
Murphy, Roland. Ecclesiastes. Word Biblical Commentary, Vol. 23a. Nashville: Thomas Nelson, 1992.

1986. . Medieval Exegesis of Wisdom Literature: Essays. Atlanta: Scholars Press, . “On Translating Ecclesiastes." Catholic Biblical Quarterly 53 (1991): 571-79.

."Qohelet Interpreted: The Bearing of the Past on the Present." Vetus Testamentum 32 (1982): 331-37.

. The Tree of Life: An Exploration of Biblical Wisdom Literature, $3^{\text {rd }}$ revised ed. Grand Rapids: Eerdmans, 1990.

Obayashi, Hiroshi, ed. Death and Afterlife: Perspectives of World Religions. Westport, CT : Glenwood Press, 1992.

Ogden, Graham S. Qoheleth. Readings-A New Bible Commentary. Sheffield: JSOT Press, 1997.

. "Qoheleth's Use of the 'Nothing is Better'-Form," Journal of Biblical Literature 98 (1979): 339-50.

."Qoheleth 9:17-10:20: Variations on the Theme of Wisdom's Strength and Vulnerability." Vetus Testamentum 30 (1980): 27-37.

. "Qoheleth 11:1-6." Vetus Testamentum 33 (1983): 222-30.

. "Qoheleth IX: 1-16," Vetus Testamentum 32 (1982): 158-69.

. "Qoheleth XI 7 - XII 8: Qoheleth's Summons to Enjoyment and Reflection," Vetus Testamentum 34 (1984): 27-38. (1984): 446-53.

"The Mathematics of Wisdom: Qoheleth 4:1-12." Vetus Testamentum 34

. "Vanity', it Certainly is Not," Bible Translator 38 (1987): 301-07.

Ogden, Graham S. and Lynell Zogbo. A Handbook on Ecclesiastes, UBS Handbook Series. New York: United Bible Societies, 1997.

Osborn, N. D. "A Guide for Balanced Living: An Exegetical Study of Ecclesiastes 7:114." Bible Translator 21 (1970): 185-96. 
Padget, Alan G. God, Eternity, and the Nature of Time. New York, St. Martin's Press, 1992.

Parsons, Greg W. "Guidelines for Understanding and Proclaiming the Book of Ecclesiastes, Part 1." Bibliotheca Sacra 160, no. 638 (2003): 159-73.

."Guidelines for Understanding and Proclaiming the Book of

Ecclesiastes, Part 2." Bibliotheca Sacra 160, no. 639 (2003): 283-304.

Payne, J. Barton. The Theology of the Older Testament. Grand Rapids: Zondervan, 1962.

Pelikan, J., ed. Luther's Works. St. Louis: Concordia, 1972

Perdue, Leo G. Wisdom and Creation: The Theology of Wisdom Literature. Nashville: Abingdon, 1994.

Perry, T. A. Dialogues with Kohelet. University Park, Pennsylvania: The Pennsylvania State University Press, 1993.

Peterson, Eugene H. The Message: Old Testament Wisdom Books. Colorado Springs: NavPress, 1997.

Polk, T. "The Wisdom of Irony: A Study of Hebel and its Relation to Joy and Fear of God in Ecclesiastes," Studies in Biblical Theology 6.1 (1976): 3-17.

Provan, Iain. Ecclesiastes/Song of Songs. NIV Application Commentary. Grand Rapids: Zondervan, 2001.

Rudman, Dominic. "Determinism and Anti-determinism in the Book of Koheleth." Jewish Bible Quarterly 30 no. 2 (2002): 97-106.

. Determinism in the Book of Ecclesiastes. JSOTSup 316. Sheffield: Sheffield Academic Press, 2001.

Sailhamer, John H. Introduction to Old Testament Theology: A Canonical Approach. Grand Rapids: Zondervan, 1995.

Salyer, Gary D. Vain Rhetoric: Private Insight and Public Debate in Ecclesiastes JSOTSup 327. Sheffield: Sheffield Acedemic Press, 2001.

Sandy, D. Brent. Plowshares and Pruning Hooks: Rethinking the Language of Biblical Prophecy and Apocalyptic. Downers Grove: Intervarsity, 2002.

Sandy, D. Brent and Ronald L. Geise, Jr. Cracking Old Testament Codes: A Guide to Interpreting the Literary Genres of the Old Testament. Nashville: Broadman and Holman, 1995. 
Schoors, A. "Koheleth: A Perspective of Life after Death?" Ephemerides Theologicae Lovanienses 61 (1985): 295-303.

. The Preacher Sought to Find Pleasing Words: A Study of the Language of Qohelet. Orientalia Lovaniensia Analecta 41. Leuven, Belgium: Peeters Publishers, 1992.

. The Preacher Sought to Find Pleasing Words: A Study of the Language of Qohelet, Part II, Vocabulary. Orientalia Lovaniensia Analecta 143. Leuven, Belgium: Peeters Publishers, 2004. Press, 1998.

. ed. Qohelet in the Context of Wisdom. Leuven, Belgium: Leuven University

Schottroff, W. and W. Stegemann, Translated by M.J.O'Connell. The God of the Lowly: Socio-Historical Interpretations of the Bible. Maryknoll: Orbis, 1984.

Schwab, George M. "Woman as the Object of Qohelet's Search." Andrew University Seminary Studies 39 no 1 (2001): 73-84.

Scott, R. B. Y. Proverbs, Ecclesiastes: A New Translation with Introduction and Commentary. New York: Doubleday, 1965.

Scott, R. R. "Qoheleth and Christian Interpretation: An Investigation of the View of God in Ecclesiastes." M.A. thesis, Trinity Evangelical Divinity School, 1985.

Searle, John R. "Metaphor," in Metaphor and Thought, $2^{\text {nd }}$ ed. Cambridge: Cambridge University Press, 1993.

Seow, Choon-Leong. "Beyond Mortal Grasp: The Usage of Hebel in Ecclesiastes." Australian Biblical Review 48 (2000): 1-16.

Ecclesiastes. Anchor Bible. New York: Doubleday, 1997.

."Theology When Everything is Out of Control." Interpretation 55 no 3 (2001): 237-49.

Shank, H. Carl. "Qohelth's World and Life View as Seen in his Recurring Phrases." Westminster Theological Journal 37 (1974): 57-73.

Sharp, Carolyn J. "Ironic Representation, Authorial Voice, and Meaning in Qohelet." Biblical Interpretation 12, no. 1 (2004): 37-68.

Shields, Martin A. The End of Wisdom: A Reappraisal of the Historical and Canonical Function of Ecclesiastes. Winona Lake, IN: Eisenbrauns, 2006. 
Siegfried, C. Prediger und Hoheslied. Handkommentar zum Alten Testament. Göttingen: Vandenhoeck und Ruprecht, 1898.

Soskice, Janet Martin. Metaphor and Religious Language. Oxford: Clarendon, 1985.

Spangenberg, Izak J. J. "Irony in the Book of Qohelet." Journal for the Study of the Old Testament 72 (1996): 57-69.

Spronk, Klaas. Beatific Afterlife in Ancient Israel and in the Ancient Near East. Kevelaer: Butzon und Bercker, 1986.

Smith, L. Lowell. "A Critical Evaluation of the Book of Ecclesiastes." Journal of Bible and Religion 21 (1953): 100-05.

Staples, W. E. "The 'Vanity' of Ecclesiastes." Journal of Near Eastern Studies 24 (1943): 95-104

Stein, Jess. Editor in chief, Random House College Dictionary of the English Language, Revised ed. New York: Random House, 1988.

Surrin, Kenneth. Theology and the Problem of Evil. Oxford: Basil Blackwell Limited, 1986.

Tamez, Elsa. "Ecclesiastes: A Reading from the Periphery." Interpretation 55, no. 3 (2001): 250-59.

When the Horizons Close: Rereading Ecclesiastes. Maryknoll, NY: Orbis Books, 2000.

Tidball, Derek. That's Life! Realism and Hope for Today from Ecclesiastes. Leicester: Intervarsity, 1989.

Tomasino, Anthony J. Judaism before Jesus: The Events and Ideas that Shaped the New Testament World. Downers Grove: Intervarsity, 2003.

Tromp, Nicholas J. Primitive Conceptions of Death and the Nether World in the Old Testament. Rome: Pontifical Biblical Institute, 1969.

VanGemeren, Willem A., gen. ed. New International Dictionary of Old Testament Theology and Exegesis. Grand Rapids: Zondervan, 1997.

Vanhoozer, Kevin J. ed. Dictionary for Theological Interpretation of the Bible. Grand Rapids: Baker Academic, 2005. 
Verbrugge, Verlyn D. ed. New International Dictionary of New Testament Theology, Abridged ed. Grand Rapids: Zondervan, 2000.

von Rad, Gerhad. Old Testament Theology. Translated by D.M.G. Stalker. New York: Harper and Row, 1962.

Waddle, Ray. Against the Grain: Unconditional Wisdom from Ecclesiastes. Nashville: Upper Room Books, 2005.

Waltke, Bruce K. and M. O'Conner. An Introduction to Biblical Hebrew Syntax. Winona Lake, Indiana: Eisenbruans, 1990.

Wegner, Paul D. The Journey from Texts to Translations. Grand Rapids: Baker Academic, 1999.

Wernik, Uri. "Will the Real Homosexual in the Bible Please Stand Up?" Theology and Sexuality 11 no. 3 (2005): 47-64.

Wheelwright, Philip. Metaphor and Reality. Bloomington: Indiana University Press, 1962.

White, G. "Luther on Ecclesiastes and the Limits of Human Ability." Neue Zeitschrift für systematische Theologie 29 (1987): 180-94.

Whitley, C. F. Koheleth: His Language and Thought. Beihefte zur Zeitschrift für die alttestamentliche Wissenschaft 148. Berlin: Walter de Gruyter, 1979.

Whybray, R.N. Ecclesiastes. Sheffield, England: Sheffield Academic Press, 1989. (1982): 87-98.

Wiersbe, Warren W. Be Satisfied. Colorado Springs: Chariot Victor, 1990.

Williams, James G. "What Does it Profit a Man: The Wisdom of Koheleth." Judaism 20 (1971): 179-93.

Williams, Neal D. "A Biblical Theology of Ecclesiastes." Th.D. diss., Dallas Theological Seminary, 1984.

Wilson, Gerhald H. "The Words of the Wise: The Intent and Significance of Qohelet 12:9-14." Journal of Biblical Literature 103, no. 2 (1984): 175-92.

Witzenrath, Hagia Hildegard. Süss ist das Licht: eine literaturwissenschaftliche Untersuchung zu Koh 11,7 - 12,7. St. Ottiliten: EOS Verlag, 1979. 
Wolfel, Eberhard. Luther und die Skepsis. Munich, 1958.

Wright, J. Robert. Old Testament LX: Proverbs, Ecclesiastes, Song of Solomon. Ancient Christian Commentary on Scripture. Grand Rapids: Intervarsity, 2005.

Zimmerli, Walther. "Das Buch des Predigers Salomo," Spruche/Prediger. Das Alte Testament Deutsch 16/1 Göttingen: Vandenhoeck \& Ruprect, 1962.

Zimmermann, Frank. The Inner World of Qohelet. New York: KTAV Publishing House, 1973.

Zuck, Roy B. A Biblical Theology of the Old Testament. Chicago: Moody, 1991. . ed. Reflecting With Solomon: Selected Studies on the Book of Ecclesiastes. Eugene, Oregon: Wipf and Stock Publishers, 1994. 